UNIVERSIDADE DE SÃO PAULO

FACULDADE DE FILOSOFIA, LETRAS E CIÊNCIAS HUMANAS

DEPARTAMENTO DE FILOSOFIA

PROGRAMA DE PÓS-GRADUAÇÃO EM FILOSOFIA

MARIO RODRIGUES VIDEIRA JUNIOR

\title{
A LINGUAGEM DO INEFÁVEL: MÚSICA E AUTONOMIA ESTÉTICA NO ROMANTISMO ALEMÃO
}


UNIVERSIDADE DE SÃO PAULO

FACULDADE DE FILOSOFIA, LETRAS E CIÊNCIAS HUMANAS

DEPARTAMENTO DE FILOSOFIA

PROGRAMA DE PÓS-GRADUAÇÃO EM FILOSOFIA

\title{
A LINGUAGEM DO INEFÁVEL: MÚSICA E AUTONOMIA ESTÉTICA NO ROMANTISMO ALEMÃO
}

\author{
Mario Rodrigues Videira Junior
}

Tese apresentada ao Programa de PósGraduação do Departamento de Filosofia da Faculdade de Filosofia, Letras e Ciências Humanas da Universidade de São Paulo, para a obtenção do título de Doutor em Filosofia.

Orientador: Prof. Dr. Marco Aurélio Werle

São Paulo

2009 
Para Geni, Mário e Gil 


\section{Agradecimentos}

Ao Prof. Dr. Marco Aurélio Werle, orientador e amigo, pelo rigor no acompanhamento desta pesquisa, pela leitura sempre cuidadosa e pelas inúmeras observações e comentários às versões preliminares deste trabalho, e por todo o apoio ao longo de minha formação e de meu percurso acadêmico na filosofia;

Ao Prof. Dr. Manfred Frank, por orientar meu estágio de pesquisa na Universidade de Tübingen (Alemanha) entre abril de 2007 e março de 2008 ;

À Profa. Dra. Lia Tomás e ao Prof. Dr. Márcio Suzuki, pelas indicações bibliográficas e valiosas sugestões apresentadas por ocasião do exame de qualificação;

Aos professores: Marisa Ramires, Victor Knoll e Yara Caznók, pelas sugestões e críticas;

A Regina Ronca e Klaus Thiel (Dresden), meus eternos professores de alemão;

Às funcionárias das bibliotecas da Universidade de Tübingen: Antje Oswald, Maike Oswald e Edith Klingenberg;

Às secretárias do Departamento de Filosofia da FFLCH-USP, especialmente à Maria Helena de Souza e Marie Márcia Pedroso;

Aos amigos do Grupo de Estudos de Estética, em especial: Cauê Polla, Pedro Galé, Carol Zoccoli e Ulisses Vaccari;

Aos meus amigos: Antônio Ribeiro, Cristina Agostini, Daniel Lago Monteiro, Felipe Salvador, Gilberto Chaves, Jacques Pécréaux, Jandira Oliveira, João Argolo, Juliana Damião Christmann, Igor Silva Alves, Lena Grossmann, Lou-Ann Kleppa, 
Lua Nogueira, Luciana Noda, Luciana Sayure, Luiz Fernando B. Martin, Magaly Malet, Maria Cecília Mansur, Mariana Lopes, Renata Itagyba, Renato Figueiredo, Ricardo Zanchetta, Said Tuma, Sandra Cervera, Sebastian Schuol, Shanda Olandoski, Sigrid Karlstrom, Stefano Stival, Tamara Silvestre, Tatiana Vasconcelos, Thiago Rodrigues, Vanessa Nonis, Vicente de Arruda Sampaio e Viviane Louro, pelo apoio e carinho em todos os momentos;

A Elena Ritossa, Kathrin Goretzki e Luci Ribeiro, meus "anjos da guarda” na Alemanha;

Aos meus tios Eliani Videira, Izaura Jerônimo e José Carlos Videira;

Aos meus irmãos, Rafael Videira e Renato Videira;

Aos meus pais, Geni Gerônimo Videira e Mário Rodrigues Videira;

À Capes, pelo apoio financeiro no Brasil;

Ao DAAD e ao CNPq, pela bolsa de estudos concedida durante meu estágio de pesquisa na Alemanha. 


\section{Resumo}

O presente trabalho tem como objetivo principal investigar o problema da autonomia estética da música instrumental no Romantismo alemão. Através do exame de textos filosóficos, literários e de crítica musical, procuramos investigar a seguinte questão: como foi possível que a arte musical - que até o século XVIII era considerada como um objeto "indigno" para a filosofia e para a estética - se estabelecesse como a esfera mais elevada do espírito humano no Romantismo e no Idealismo alemão? A fim de responder a essa pergunta, pareceu-nos necessário levar em conta a maneira pela qual se compreendia a música no século XVIII e qual o conceito de razão que estava em sua base. A principal hipótese que procuramos explorar diz respeito à filosofia crítica de Kant, que permitiu que o pensamento encontrasse um paradigma na música. Com a chamada "revolução copernicana", Kant acentuou a subjetividade de maneira radical, abrindo, pela primeira vez, a possibilidade da música ser reconhecida como uma linguagem não-objetiva, que foi desenvolvida principalmente por autores como Wackenroder, Tieck e Hoffmann. Todavia, as condições de possibilidade para a compreensão da música como "expressão do inefável", bem como a proximidade que se estabelece entre música e religião, devem ser buscadas primeiramente na filosofia kantiana.

Palavras-Chaves: Autonomia estética; Música Instrumental; Romantismo Alemão; Intuição Estética; Gênio. 


\section{Abstract}

The main purpose of this research is to examine the problem concerning the aesthetic autonomy of instrumental music in German Romanticism. Through the examination of philosophical and literary texts, as well as musical criticism, the following question is investigated: how was it possible that the musical art - which was considered an "unworthy" object for the philosophy and the aesthetics until the $18^{\text {th }}$ Century - could establish itself as the highest sphere of the human spirit during the Romanticism and the German Idealism? In order to answer to this question, it seems necessary to take into account the way music was understood during the $18^{\text {th }}$ Century and what conception of Reason lay in its basis. Our main hypothesis concerns Kant's critical philosophy, which made possible the thought of finding a paradigm in music. With the so called "Copernican revolution", Kant stressed subjectivity in a radical way and, for the first time, provided the possibility of recognizing the music as a non-objective language, developed later by authors like Wackenroder, Tieck and Hoffmann. However, the conditions of possibility for the understanding of music as "expression of the ineffable", as well as the proximity established between music and religion, must be searched firstly in the Kantian philosophy.

Key-Words: Aesthetic autonomy; Instrumental music; German Romanticism; Aesthetic Intuition; Genius. 


\section{Zusammenfassung}

Die vorliegende Studie befasst sich mit dem Problem der ästhetische Autonomie der Instrumentalmusik in der deutschen Romantik. Ausgangspunkt der Forschung ist, folgende Frage zu beantworten: wie konnte die Musik, die im 18. Jahrhundert ein „unwürdiger" Gegenstand für die Philosophie und für die Ästhetik war, sich als höchsten Bereich des menschlichen Geistes in der Romantik und im deutschen Idealismus festsetzen? Um diese Frage zu beantworten scheint es uns notwendig zu beachten, wie man die Musik im 18. Jahrhundert verstand und welchen Begriff der Vernunft man damals zugrunde legte. Die Haupthypothese, der man nachgehen möchte, bezieht sich auf Kants Kritische Philosophie, die es dem Denken erst ermöglichte, ein Paradigma in der Musik zu finden. Mit der sogenannten "kopernikanischen Wende" betonte Kant die radikale Subjektivität und eröffnete zum ersten Mal die Möglichkeit, die Musik als nicht objektive Sprache zu würdigen. Diesen Schritt des Denkens, insbesondere die Musik betreffend, findet man aber nicht in Kants Werk, sondern bei Autoren wie Wackenroder, Tieck und Hoffmann. Die Bedingungen der Möglichkeit, die Musik als „Ausdruck des Unaussprechlichen“ zu verstehen, sowie die Nähe, die sich zwischen Musik und Religion etabliert, muss man jedoch zuerst in der Kantschen Philosophie suchen. 
"A arte é uma mediadora do indizível".

"Uma obra de arte autêntica [...] permanece sempre infinita para o nosso entendimento; ela é contemplada, sentida, faz efeito, mas não pode ser propriamente conhecida, muito menos podem ser expressos em palavras sua essência, seu mérito".

(Johann Wolfgang Goethe)

"Toda linguagem é indireta ou alusiva e, se quisermos, silêncio".

"Música como modelo de significação - deste silêncio do qual a linguagem é feita. [...] A música, como a pintura, é no mundo sensível o que é a filosofia no mundo inteiro".

(Maurice Merleau-Ponty)

"Música e filosofia são as tentativas de dizer o indizível. Ambas são o desdobramento desse paradoxo. Ambas desejam curar a linguagem do conceito. [...] Mas também a música é linguagem, ela diz mais do que ela meramente é".

(Theodor W. Adorno) 


\section{ÍNDICE}

I. DA IMITAÇÃO À EXPRESSÃO

A influência do pensamento francês no cenário intelectual alemão 17

A crise no paradigma da imitação: Moritz e Smith 22

II. GÊNIO E ARTE COMO EXPRESSÃO DA SUBJETIVIDADE 34

III. WACKENRODER, TIECK E A IDÉIA DE UMA RELIGIÃO DA ARTE

Desabafos e fantasias de um monge amante da arte $\quad 50$

Crítica de arte e teoria da linguagem $\quad 58$

Os escritos musicais de Berglinger $\quad 83$

IV. KANT E SCHELLING: DA INTUIÇÃO INTELECTUAL À INTUIÇÃO ESTÉTICA 91

\section{A RECEPÇÃO DA CRÍTICA DO JUÍZO PELOS TEÓRICOS E CRÍTICOS MUSICAIS}

A ambigüidade da música: arte bela ou meramente agradável? 117

Música e autonomia: Michaelis e a noção de idéia estética 130

VI. CRÍTICA MUSICAL ENQUANTO TEORIA ESTÉTICA 145

Música instrumental pura como modelo da arte romântica 149

O Romantismo e o Sublime 153

A Sinfonia e o sublime: a ode pindárica como paradigma da obra de arte genial. $\quad 156$

A concepção do gênio musical na recensão da "Quinta Sinfonia" 160

$\begin{array}{lr}\text { CONSIDERAÇÕES FINAIS } & 171\end{array}$

APENDICES: $\quad 181$

Apêndice 1: SULZER, J. G. Allgemeine Theorie der schönen Künste. 182

Apêndice 2: KOCH, H. C. Versuch einer Anleitung zur Composition. 190 
Apêndice 3: MICHAELIS, C. F. "Noch einige Bemerkungen über den Rang der Tonkunst unter den schönen Künsten".

Apêndice 4: MICHAELIS, C. F. "Ueber das Idealische der Tonkunst". 199

Apêndice 5: HOFFMANN, E. T. A. Schriften zur Musik. 203

REFERÊNCIAS BIBLIOGRÁFICAS 226 


\section{INTRODUÇÃO}

Em sua famosa recensão sobre a Quinta Sinfonia de Beethoven, publicada originalmente em 1810 no Allgemeine Musikalische Zeitung de Leipzig, o escritor, compositor e crítico de música E.T.A. Hoffmann afirma:

Quando se fala da música enquanto arte autônoma [selbständige Kunst] deve-se pensar sempre na música instrumental, a qual desprezando qualquer ajuda, qualquer mistura de outras artes, exprime de maneira característica e pura a essência da arte, que somente nela se dá a conhecer. Ela é a mais romântica de todas as artes, - poder-se-ia quase dizer: a única puramente romântica. ${ }^{1}$

Não por acaso este é considerado um dos textos fundadores do romantismo na música: nele vemos a música instrumental, que há até poucos anos antes era considerada uma forma de arte inferior, transformada no gênero mais apto a expressar, de maneira pura, a própria essência da Arte.

Se compararmos essa valorização estética da música instrumental que se dá no início do século XIX com as teorias de arte anteriores teremos a medida exata da originalidade desse pensamento que, ao mesmo tempo, está intimamente ligado a um processo que vinha se desdobrando já desde as últimas décadas do século XVIII, a saber, o processo de autonomização da música e a questão concernente à sua legitimação estética.

HOFFMANN, E.T.A. Schriften zur Musik. Darmstadt: Wissenschaftliche Buchgesellschaft, 1971, p. 34. 
Seria de fato a música, tal como afirmou Kant, mais gozo [Genuß] do que cultura [Kultur] $?^{2}$ Com que direitos a música instrumental pura, independente de um texto ou de uma função social/religiosa poderia aspirar a uma posição de destaque dentre as belas-artes?

Essas questões são centrais para que possamos compreender a mudança radical que se dá no pensamento estético sobre a música nesse período, pois é somente com a legitimação da música como arte autônoma que se abre a possibilidade, até então problemática e controversa, de incluir a música entre as demais belas-artes e, mais do que isso, de lhe outorgar a posição mais elevada na hierarquia das artes em geral.

Como bem mostrou o musicólogo alemão Carl Dahlhaus em diversos estudos (Die Idee der absoluten Musik, Klassische und Romantische Musikästhetik, etc), surge a partir desse momento o que se poderia chamar de uma "metafísica da música instrumental". ${ }^{3} \mathrm{Se}$ anteriormente havia uma certa incompatibilidade entre música e filosofia, se a música era considerada grosso modo um objeto inadequado para a reflexão filosófica, pois "julgada pela razão" ela possuiria "menor valor que qualquer outra das belas-artes"4, a partir do Romantismo a música se torna o centro da discussão sobre a arte em geral, o modelo ao qual aspiram todas as demais artes. ${ }^{5} \mathrm{Na}$ música, segundo Schopenhauer, "não se deseja ir além, [pois] se possui Tudo, atingiu-se o objetivo; esta arte é

${ }^{2}$ KANT, I. Kritik der Urteilskraft. Hamburg: Felix Meiner, 2001, § 53, B 218 (doravante: $\mathrm{KdU})$.

${ }^{3}$ A passagem de uma estética da música vocal para uma estética baseada na música instrumental pura não significa que não houvesse anteriormente música instrumental de qualidade. Mas o fato de tratá-la como expressão do Absoluto é algo que surge apenas nessa época.

${ }^{4}$ Cf. KANT, KdU, § 53, B218.

${ }^{5}$ No Fragmento 1359, por exemplo, Schlegel considera que: "o método do romance é [o mesmo] da música instrumental. No romance os personagens podem ser tratados de maneira tão arbitrária [willkürlich] como a música trata [behandelt] seu tema". In: SCHLEGEL, F. Literarische Notizen Notizen 1797-1801. Hg: Hans Eichner. Frankfurt/M: Ullstein, 1980, p.146. 
auto-suficiente [allgenugsam] e nela o mundo está completamente repetido e manifestado. Ela é a primeira, a rainha das Artes. O objetivo [Ziel] de toda arte é tornar-se como a música". 6

Se anteriormente a música instrumental era alvo de duras críticas devido ao seu caráter não-conceitual e não-referencial, ela passa agora a ser considerada - justamente por causa dessas características - como a mais universal das artes: Friedrich Schlegel afirma que a música é "a mais alta dentre todas as artes. Ela é a mais universal [die allgemeinste]. Toda arte possui princípios musicais e, acabada, se torna ela mesma, música. Isso é válido até mesmo para a filosofia e logo, também para a poesia".7 Essa afinidade entre música instrumental e filosofia é também expressa pelo mesmo autor no Fragmento 444 do Athenäum:

[...] quem possui sentido para as maravilhosas afinidades de todas as artes e ciências, ao menos não irá considerar a coisa a partir do ponto de vista comum da assim chamada naturalidade, segundo o qual a música deve ser somente a linguagem do sentimento [Sprache der Empfindung], e não achará impossível em si uma certa tendência de toda a música instrumental pura para a filosofia. ${ }^{8}$

Frente a essa radical transformação que se opera na consideração estética da música a partir do Romantismo, podem-se colocar as seguintes questões: Quais foram as condições que tornaram possível que a linguagem musical, no espaço de poucas décadas, pudesse adquirir um valor tão elevado para a filosofia em comparação com as demais artes? Existe alguma relação entre o pensamento puro e a música pura, ou entre

${ }^{6}$ SCHOPENHAUER, A. Handschriftlicher Nachlaß Bd. IV (Neue Paralipomena). Hrsg. E. Grisebach. Leipzig: Reclam, 1931, p. 30.

${ }^{7}$ SCHLEGEL, F. Literarische Notizen, p. 151 (frag. 1147). No fragmento 1416 (Op. Cit., p. 151) ele afirma ainda: "A música é, dentre as artes, o que a religião é no mundo e a álgebra, na matemática. Ela é nada e tudo, centro e raio; o belo supremo [höchste Schöne] e o arbítrio".

8 SCHLEGEL, F. Kritische Ausgabe. Bd. 2. Hg. E. Behler. Paderborn, Ferdinand Schöningh, 1958ss. (Doravante: KA, seguido do número do volume e da página), p. 254. 
a revolução ocorrida na filosofia a partir de Kant e a consideração estética da música como linguagem pura?

Para tentar responder a tais questões, partimos da hipótese de que, além das transformações técnicas na música (aperfeiçoamento dos instrumentos, surgimento de novas formas musicais, etc) e das transformações sociais, também a revolução filosófica iniciada por Kant e sua recepção pelos autores do Primeiro Romantismo [Frühromantik] permitiram não apenas que a música se tornasse um objeto adequado e digno da reflexão filosófica, mas também que a própria filosofia encontrasse um paradigma na música. Através dos textos de estética musical alemã do período em torno de 1800 pode-se notar claramente, por um lado, a influência marcante das teses apresentadas por Kant em sua Terceira Crítica e, por outro lado, uma tentativa de conceder à música uma certa dignidade e valor perante as demais artes. Esta tentativa, que na realidade procura ultrapassar a letra kantiana, está intimamente ligada à procura da determinação das condições de possibilidade para a consideração da música como arte bela - e não como arte meramente agradável aos sentidos - e de sua legitimação enquanto objeto estético autônomo. Mais ainda: foi graças ao confronto com as teses kantianas e utilizando em parte as próprias ferramentas teóricas proporcionadas pela filosofia crítica, que alguns autores pós-kantianos tornaram possível a já mencionada elevação da música instrumental pura e autônoma a modelo supremo para as demais artes, capaz de chegar a um pressentimento do Absoluto.

Essa mudança na consideração estética da música pode ser verificada já nos textos de Wackenroder, nos quais ela é considerada como a mais maravilhosa dentre as belas-artes, "capaz de descrever os sentimentos humanos de forma sobre-humana", uma linguagem intraduzível, "cuja pátria ninguém conhece e que comove todos os seres 
até a mais íntima fibra". ${ }^{9}$ A linguagem das palavras é por ele considerada um instrumento demasiado grosseiro, incapaz de apreender o incorpóreo. Por outro lado, a música seria capaz de exprimir o inefável, falando diretamente à essência da alma humana. Wackenroder afirma que:

[...] nenhuma outra arte consegue fundir de modo tão enigmático as qualidades da profundidade, da força sensível e do significado obscuro e fantástico. E é em virtude desta estreita e notável união de qualidades [...] que [a música] se orgulha de sua superioridade..$^{10}$

A suposta obscuridade da música instrumental, principal alvo das críticas dos estetas do início do século XVIII será justamente a qualidade mais valorizada por Wackenroder, para quem a música constitui-se na arte que "sem dúvida age sobre nós com tanto mais força [...] quanto mais obscura e misteriosa é sua linguagem". ${ }^{11}$ É essa força misteriosa da música que consegue exprimir o que há de mais elevado, a "divindade da arte" [Göttlichkeit der Kunst].

O espírito religioso, de devoção e recolhimento perante a arte aparece também nos textos de autoria de Ludwig Tieck. Também para ele, a música se apresenta como "a mais obscura de todas as artes", e é devido a essa obscuridade que ele a considera como "o mistério último da fé, a mística, a religião totalmente revelada". Ao enumerar as maravilhosas qualidades da música, ele pergunta a si mesmo: "O que é que tão poderosamente nos fala ao coração, mais do que as leis, do que a razão e toda a filosofia?". ${ }^{2}$

\footnotetext{
${ }^{9}$ WACKENRODER, W. H. Sämtliche Werke und Briefe. Historisch-kritische Ausgabe in 2 Bde. Hg. S. Vietta, R. Littlejohns. Heidelberg: Carl Winter, 1991 (Doravante: HKA, seguido do número do volume e da página), HKA I, p. 207. Trad. Port. IRIARTE, R. (Org). Música e Literatura no Romantismo Alemão. Lisboa: Apaginastantas, 1987, p. 2930.

${ }^{10}$ WACKENRODER, W. H. HKA I, p. 217. Trad. Port. IRIARTE, R. Op. Cit., p. 39.

${ }^{11}$ WACKENRODER, W. H. HKA I, p. 134.

${ }^{12}$ WACKENRODER, W. H. HKA I, p. 230. Trad. Port. IRIARTE, R. Op. Cit., p. 50-6.
} 
Para Tieck, a música vocal constitui-se numa arte ainda limitada, enquanto que a música instrumental é uma arte independente e livre, que alcança o objetivo mais elevado e exprime o que há de mais profundo, tornando-se assim o modelo ao qual aspiram todos os outros gêneros de música instrumental.

Também nos escritos sobre música de E. T. A. Hoffmann encontramos alguns dos temas presentes nos textos de Wackenroder e Tieck, sobretudo no que diz respeito à valorização da música instrumental devido ao seu caráter misterioso, obscuro e enigmático. Hoffmann pergunta-se: "Não é a música a linguagem misteriosa de um longínquo reino de espíritos, cujos maravilhosos sons ressoam no nosso íntimo e despertam uma vida superior e mais intensa?". ${ }^{13}$ Para Hoffmann, somente a música instrumental pura, que com sua lira é capaz de desvendar "o maravilhoso reino espiritual do Infinito" [Unendlichen] é uma arte verdadeiramente Romântica. ${ }^{14}$

Muitas das idéias presentes nos textos desses autores influenciaram não apenas a reflexão posterior sobre a música, mas também a própria produção artística de alguns compositores ao longo do século XIX: se até então a música instrumental era considerada como um gênero artístico de menor importância, seja devido à falta de um conteúdo claramente definido, seja por sua imitação imperfeita da natureza, seja por sua suposta imprecisão e obscuridade, não passando de um mero passatempo ou de um pequeno "luxo inocente", encontramos nos textos desses autores uma inversão completa desse julgamento, e a música instrumental é alçada à posição mais elevada, modelo para as demais

13 HOFFMANN, E. T. A. Die Serapions-Brüder. Darmstadt: Wissenschaftliche Buchgesellschaft, 1995, p. 83. Trad. Port. "O poeta e o compositor". In: IRIARTE, R. Op. Cit., p. 119.

${ }^{14}$ HOFFMANN, E. T. A. Schriften zur Musik, 1971, p. 37. 
artes, uma linguagem capaz de exprimir aquilo que está além das palavras.

No centro dessa pesquisa está, portanto, a revolução kantiana na filosofia, sua recepção e seus desdobramentos nos debates acerca da autonomia da música. Desse modo, delimita-se o contexto histórico deste trabalho, a saber: a estética e filosofia alemãs da passagem do século XVIII para o século XIX.

É preciso ressaltar que nossa abordagem se propõe mais como temática do que de história da filosofia. Isto é, a partir de alguns autores selecionados - tanto compositores, teóricos e críticos musicais, como também filósofos (os quais se ocuparam também de música) - buscamos acompanhar um tema que vai se articulando nesse período: a autonomia da música. Tendo em vista essa abordagem de via dupla, temos consciência de que em alguns momentos não nos detemos em certos pormenores que poderiam ser levados em conta. Por outro lado, acreditamos que a iluminação recíproca de textos filosóficos e "musicais", bem como a tentativa de reconstrução de uma questão de época exige o estabelecimento de um percurso mais amplo. É esse o espírito que preside a investigação que se segue.

Quanto à estrutura geral, o trabalho está dividido em seis capítulos: no primeiro, procuraremos mostrar a posição de inferioridade que a música - especialmente a música instrumental - tradicionalmente ocupava, em comparação com as demais artes belas. Trata-se ainda de situar a música no contexto da polêmica entre uma corrente estética que privilegiava a imitação e outra, que dava primazia ao efeito. Em seguida, acentuaremos a transformação pela qual passa a estética musical no final 
do século XVIII e a crise do paradigma da imitação na arte da música, exemplificada pelas teorias de K. P. Moritz e Adam Smith.

No segundo capítulo examinaremos a concepção de arte como produto do gênio e o surgimento da idéia de uma expressão dos sentimentos subjetivos do compositor através da música. A seguir, no terceiro capítulo, analisaremos algumas passagens dos livros escritos conjuntamente por W. H. Wackenroder e L. Tieck, a fim de verificar de que maneira suas críticas à estética racionalista e suas concepções acerca da arte e do gênio conduzem a uma valorização da música como uma linguagem elevada, capaz de expressar aquilo que a linguagem das palavras não é capaz.

O quarto capítulo terá como objetivo analisar as conseqüências da revolução filosófica kantiana no campo da estética, mostrando como a tentativa de resolução do problema da ligação entre razão teórica e razão prática, bem como a exigência de um primeiro princípio absoluto e incondicionado para a filosofia acabam desembocando, no Sistema do Idealismo Transcendental de Schelling, na consideração da arte como verdadeiro órganon da filosofia.

Em seguida, no capítulo quinto, procuraremos ver de que forma se dá a primeira recepção da Crítica do Juízo, principalmente pelos teóricos e críticos da música, bem como a tentativa destes de ir além de Kant. Nesse mesmo capítulo analisaremos alguns dos principais textos de $\mathrm{C}$. $\mathrm{F}$. Michaelis, um autor relativamente obscuro e desconhecido, mas cujos artigos desempenharam um papel importante para a autonomização estética da música, servindo como um dos elos de ligação entre a reflexão kantiana e a dos autores românticos.

Por fim, no sexto capítulo, procuraremos ver como essas questões são sintetizadas na crítica musical do escritor e compositor E. T. A. Hoffmann, e como suas teorias estéticas são tributárias, por um lado, da 
reflexão sobre o sublime e, por outro lado, das reflexões estéticas do Primeiro Romantismo alemão. ${ }^{15}$

\footnotetext{
15 Uma última observação: devido ao caráter interdisciplinar deste trabalho, algumas passagens poderão parecer excessivamente didáticas. Isso se justifica pela necessidade de situar o leitor mais familiarizado com as questões de cunho puramente filosófico no contexto mais geral das discussões estético-musicais do período e, inversamente, de situar o leitor mais familiarizado com as questões técnico-musicais no âmbito da revolução filosófica pós-kantiana. Tendo em vista que grande parte das fontes primárias utilizadas neste trabalho é de difícil acesso aos pesquisadores no Brasil, e tentando suprir, ao menos em parte, essa lacuna bibliográfica, incluímos em apêndice as traduções de alguns dos textos que julgamos mais importantes para nossa discussão e que permitem perceber um contraste entre as posições estéticas concernentes à música desde meados do século XVIII até a primeira década do século XIX.
} 


\section{DA IMITAÇÃO À EXPRESSÃO}

Em seu Dicionário de Música (1768), Rousseau ${ }^{16}$ se queixa da primazia que a música puramente instrumental começava a adquirir como sendo algo "pouco natural" e de mau-gosto:

Hoje em dia os instrumentos constituem a parte mais importante da música, as sonatas estão extremamente na moda, assim como toda espécie de sinfonia; o vocal não passa de acessório e o canto acompanha o acompanhamento. [...] Eu ouso prever que um gosto tão pouco natural não durará. ${ }^{17}$

Para ele, a música, para ser considerada uma arte verdadeiramente imitativa, necessita do auxílio das palavras, as quais the conferem uma determinação que ela sozinha, enquanto música puramente instrumental não possui, ou possui em grau ínfimo, pois sendo a palavra "o meio pelo qual a música determina mais freqüentemente o objeto do qual ela nos oferece a imagem", pode-se concluir facilmente que a imitação levada a cabo pela música instrumental é demasiado obscura e não é sempre imediata como a da poesia e da pintura. Embora a música instrumental possa contribuir para animar o canto, contribuindo para sua expressão, Rousseau é taxativo ao afirmar que ela não o suplanta, e termina o verbete com uma citação que se tornaria célebre: "Jamais esquecerei a

\footnotetext{
${ }^{16}$ Rousseau utiliza o mesmo texto que havia escrito alguns anos antes para o verbete "Sonate" da Encyclopédie. Cf. Encyclopédie ou dictionnaire raisonné des sciences, des arts et des métiers. Tome 15ème. Neufchastel: Samuel Faulche \& Co., 1765, p. 348.

${ }_{17}$ ROUSSEAU, J.J. "Sonate" In: Dictionnaire de Musique. Paris: Duchesne, 1768, p. 451-52.
} 
frase do [...] Sr. de Fontenelle, o qual, estando em um concerto, exasperado por essa sinfonia eterna, gritou em alto e bom som, num transporte de impaciência, sonata, que queres de mim??. ${ }^{18}$ Em outras palavras, para Rousseau, a música é considerada como uma arte imitativa e primordialmente vocal, isto é, ela deve estar ligada à expressão das palavras. A música puramente instrumental é relegada a um plano secundário, de mero reforço à voz; e a possibilidade de uma música instrumental pura e autônoma, independente do texto é vista como algo "pouco natural" e fadado ao desaparecimento.

Ao defender a primazia da música vocal frente à música instrumental, da melodia frente à harmonia, Rousseau está não apenas tomando partido nas polêmicas de sua época, não apenas combatendo as idéias de Rameau sobre a música, mas está, principalmente, levando às últimas conseqüências suas reflexões sobre a origem das línguas e das relações entre música e linguagem. ${ }^{19}$

Ao tratar do problema da origem da linguagem ${ }^{20}$ no Discurso sobre a origem e o fundamento da desigualdade entre os homens (1755), Rousseau aponta o grito da natureza como tendo sido a primeira língua do homem e também a mais universal e a mais enérgica. Esse grito "só era proferido por uma espécie de instinto nas ocasiões mais prementes, para implorar socorro nos grandes perigos ou alívio nas dores violentas". ${ }^{21}$ Somente num segundo momento é que se the juntaram as inflexões de voz e os gestos, os quais posteriormente foram substituídos

\footnotetext{
${ }^{18}$ ROUSSEAU, J.J. "Sonate" In: Dictionnaire de Musique. Paris : Duchesne, 1768, p. $451-52$.

${ }^{19}$ De fato, se música ocupa um lugar de destaque no conjunto da obra rousseauniana, cabe notar que não é a música instrumental que está no centro e sim a música vocal. A melodia detém claramente, para Rousseau, a primazia frente à harmonia. Aquela é expressão das paixões do homem enquanto esta aparece como mero cálculo, expressão da razão.

${ }^{20}$ ROUSSEAU, J.J. Discurso sobre a origem e os fundamentos da desigualdade entre os homens. São Paulo, 1973, p. 252ss.

${ }^{21}$ ROUSSEAU, J.J. Discurso sobre a desigualdade, p. 254.
} 
pelos sinais instituídos. Contrapondo-se aos filósofos que enfatizavam o papel central da razão para o homem, Rousseau assinalava, já no Segundo Discurso, a importância fundamental das paixões. Segundo ele, é somente pela atividade das paixões "que nossa razão se aperfeiçoa; só podemos conhecer porque desejamos usufruir", de modo que "o entendimento humano muito deve às paixões" ${ }^{22}$

Essa centralidade das paixões para 0 desenvolvimento da linguagem é retomada também em seu Ensaio sobre a origem das línguas (publicado postumamente em 1781). Nesse ensaio ele procura mostrar que a primeira invenção da palavra não nasce das necessidades, mas das paixões: "Deve ter sido assim. Não se começou por raciocinar" pois para isso seria preciso que os homens já possuíssem uma linguagem - "mas por sentir". 23 Desse modo a linguagem se origina das necessidades morais do homem, ou em outras palavras, das paixões:

Não foi a fome nem a sede, mas o amor, o ódio, a piedade, a cólera que arrancaram as primeiras vozes. [...] para comover um jovem coração, para repelir um agressor injusto, a natureza dita acentos, gritos, lamentos. Eis as mais antigas palavras inventadas e eis porque as primeiras línguas foram cantantes e apaixonadas antes de serem simples e metódicas. ${ }^{24}$

Dessa forma, Rousseau irá considerar que música, poesia e linguagem tiveram uma única e mesma origem. Uma vez que:

[...] a paixão faz falar todos os órgãos e confere à voz todo o seu brilho; assim, os versos, os cantos, a palavra, têm uma origem comum. [...] os primeiros discursos foram as primeiras canções: os retornos periódicos e compassados do ritmo, as inflexões melodiosas

\footnotetext{
${ }^{22}$ ROUSSEAU, J.J. Discurso sobre a desigualdade, p. 250.

${ }^{23}$ ROUSSEAU, J.J. Ensaio sobre a origem das línguas. Campinas: Ed. Unicamp, 2003, p. 105.

24 ROUSSEAU, J.J. Ensaio sobre a origem das línguas. Campinas: Ed. Unicamp, 2003, p. 105-106.
} 
dos acentos, fizeram nascer, com a língua, a poesia e a música, ou melhor, tudo isso não era outra coisa senão a própria língua". ${ }^{25}$

Ora, se é certo que as paixões falaram antes da razão e se, a princípio "não houve outra música além da melodia, nem outra melodia além do som diversificado da palavra", então se pode afirmar que "dizer e cantar eram outrora a mesma coisa". ${ }^{26}$ É somente na medida em que aumentam as necessidades do homem que a linguagem vai, gradativamente, mudando de caráter e que essa linguagem das paixões vai, pouco a pouco, tornando-se mais precisa. Contudo, esse ganho em clareza e precisão acarreta, por outro lado, uma perda de energia, de sua força originária. Ao substituir os sentimentos por idéias, a linguagem deixa de falar ao coração e passa a falar à razão. Por isso mesmo "o acento desaparece, a articulação estende-se, a língua torna-se mais exata, mais clara, porém [...] mais surda e mais fria". 27

Se em sua origem música e linguagem foram uma só coisa, tais modificações sofridas pela linguagem acarretarão graves conseqüências para a arte dos sons. Com efeito, a melodia não apenas vai perdendo sua antiga energia, mas vai também, aos poucos, se desvinculando das palavras. Esse processo de autonomização, longe de ser visto com bons olhos por Rousseau é, pelo contrário, justamente a causa da degeneração da música de seu tempo:

A melodia, começando a não ser mais tão aderente ao discurso, adquiriu insensivelmente uma existência própria e a música tornouse mais independente em relação às palavras. Então, pouco a pouco, cessaram também esses prodígios que ela produzira quando era apenas 0 acento e a harmonia da poesia. ${ }^{28}$

\footnotetext{
${ }^{25}$ ROUSSEAU, J.J. Ensaio sobre a origem das línguas, p. 147.

${ }^{26}$ ROUSSEAU, J.J. Ensaio sobre a origem das línguas, p. 148.

${ }^{27}$ ROUSSEAU, J.J. Ensaio sobre a origem das línguas, p. 113.

${ }^{28}$ ROUSSEAU, J.J. Ensaio sobre a origem das línguas, p. 173-74.
} 
O processo de racionalização da música tem como conseqüência a primazia da harmonia, a qual, passando a regular a melodia, faz com que o canto se torne uma arte inteiramente separada da palavra. Ao limitar-se ao efeito puramente físico dos sons, a música acaba por privar-se dos seus efeitos morais. ${ }^{29}$ Tal música é vista por Rousseau como uma arte degenerada, uma arte abstrata e que nada imita, logo, incapaz de exercer qualquer efeito sobre nós.

Rousseau não nega que as engenhosas combinações harmônicas possam ser agradáveis ao ouvido. No entanto, a música não pode ser reduzida meramente às suas causas físicas. O que eleva a música à categoria das belas-artes é, para ele, a imitação. Traçando uma analogia entre pintura e música, ele escreve:

Como os sentimentos que a pintura suscita em nós não procedem das cores, o poder que a música tem sobre nossas almas absolutamente não é obra dos sons. Belas cores, bem nuançadas, agradam à vista, mas tal prazer é puramente sensitivo. É o desenho, é a imitação que confere a essas cores vida e alma; são as paixões exprimidas que vêm sensibilizar as nossas; são os objetos representados que vêm nos afetar. ${ }^{30}$

E mais adiante: "A melodia faz na música exatamente o que faz o desenho na pintura; é ela que representa os traços e as formas, cujos acordes e sons são apenas cores". ${ }^{31}$

A centralidade do conceito de imitação no âmbito das reflexões lingüísticas de Rousseau é ressaltada também por Bento Prado Jr, no ensaio intitulado "A força da voz e a violência das coisas". Segundo ele:

A teoria da imitação musical fornece o quadro de referência de uma concepção da linguagem como imitação. A perda da força, a degenerescência e a alteração do canto como a da fala são, também, o produto do esvanecimento da imitação. [...] A idéia de

\footnotetext{
${ }^{29}$ ROUSSEAU, J.J. Ensaio sobre a origem das línguas, p. 176.

${ }^{30}$ ROUSSEAU, J.J. Ensaio sobre a origem das línguas, p. 151.

${ }^{31}$ ROUSSEAU, J.J. Ensaio sobre a origem das línguas, p. 151.
} 
imitação é, então, perfeitamente central na teoria de Rousseau. [...] Num sentido, que não é o mais profundo, a música é imitativa da mesma forma que a pintura, quer dizer, no sentido em que pode evocar imagens ausentes no mundo da percepção. Mas se a música tem também, nos 'quadros' que compõe, uma função representativa, esta função é sempre transgredida em direção ao que podemos chamar de 'o irrepresentável'. Cingido ao universo do visível, o pintor não tem acesso ao invisível, enquanto o músico, através de sua linguagem indireta, é capaz de dar voz até ao silêncio. ${ }^{32}$

Ao imitar as inflexões da voz, a melodia exprime os lamentos, os gritos de dor ou de alegria; em suma, todos os sinais vocais das paixões. Mas Rousseau é enfático ao alertar para o fato de que, ao se separar canto e palavra, ao se substituir o acento apaixonado da melodia pelo cálculo dos intervalos da harmonia, põe-se a perder toda a força e expressão da música:

Ao abandonar o acento oral e ao levar em consideração somente as instituições harmônicas, a música se torna mais barulhenta para o ouvido e menos suave ao coração. Ela já cessou de falar, em breve não mais cantará; e então, com todos os seus acordes e toda a sua harmonia, não terá mais nenhum efeito entre nós. ${ }^{33}$

\section{A influência do pensamento francês no cenário intelectual alemão}

No que concerne ao pensamento musical alemão, podemos encontrar em autores dessa mesma época a defesa de pontos de vista semelhantes, o que aponta para a influência ainda bastante presente do pensamento estético francês no cenário intelectual alemão. Um exemplo pode ser encontrado no pequeno ensaio sobre a imitação da natureza na

\footnotetext{
${ }^{32}$ PRADO JR, B. "A força da voz e a violência das coisas". In: ROUSSEAU, J.J. Ensaio sobre a origem das línguas, p. 57-60.

${ }^{33}$ ROUSSEAU, J.J. Ensaio sobre a origem das línguas, p. 167.
} 
música publicado em 1755 por Johann Adam Hiller (1728-1804). ${ }^{34}$ Fortemente influenciado por Batteux ${ }^{35}$, Hiller considera que o fundamento [Grundsatz] de todas as artes belas deve ser a imitação da natureza ${ }^{36}-0$ que, no caso da música se traduz principalmente pela exigência de que ela deva ser imitação dos sentimentos. ${ }^{37}$

Também para Hiller a música instrumental é considerada como uma arte demasiado indeterminada e que necessita do auxílio da poesia:

Se é exigido que a música seja mais compreensível, ou se ela tiver que mostrar de maneira enérgica a sua força na imitação da natureza, então ela não pode se servir de um recurso melhor do que a linguagem. Ela recorre então à poesia, sua tão respeitável irmã. ${ }^{38}$

A poesia, quando unida à música, desempenha um papel análogo ao do desenho, para a pintura. ${ }^{39}$ É a poesia que fornece a determinação, a exatidão que os meros sons (comparáveis às cores da pintura), por si sós, não são capazes de fornecer. ${ }^{40}$

${ }^{34}$ HILLER, J. A. "Abhandlung von der Nachahmung der Natur in der Musik". In: Marpurg, F. W. Historisch-Kritische Beyträge zur Aufnahme der Musik. 1.Bd., 6. Stück. Berlin: Schützen, 1755. p. 515-543.

${ }^{35} \mathrm{O}$ tratado de Batteux, Les Beaux-Arts réduits à un même principe, publicado em 1746, e que procurava demonstrar que a imitação da natureza deveria ser o princípio comum a todas as belas-artes teve enorme influência nas décadas seguintes. Sua primeira tradução para o idioma alemão deve-se a Johann Adolf Schlegel, que o publicou já no ano de 1751, na cidade de Leipzig, sob o título: Einschränkung der schönen Künste auf einen einzigen Grundsatz ("Redução das Belas-Artes a um único Princípio"). Hiller refere-se a Batteux em termos bastante elogiosos: "nenhuma honraria lhe será demasiada graças à sua excelente obra [...].Creio que ele tem razão [ao considerar a imitação da natureza como o princípio de todas as belas artes]. E mesmo que não fosse esse o caso, quem não preferiria errar com tão grande homem? [...] Eu irei segui-lo, pois ele seguiu a verdade" (HILLER, J. A. "Abhandlung von der Nachahmung", p. 518-19).

${ }^{36}$ HILLER, J. A. "Abhandlung von der Nachahmung", p. 518.

37 "Portanto, os sentimentos [Empfindungen], em seu aspecto mais simples e natural, expressos somente através de sons, são o primeiro fundamento da música" (HILLER, J. A. "Abhandlung von der Nachahmung", p. 521).

${ }^{38}$ HILLER, J. A. "Abhandlung von der Nachahmung", p. 524.

${ }^{39}$ HILLER, J. A. "Abhandlung von der Nachahmung", p. 525.

${ }^{40}$ Esse pensamento estará presente também na apreciação kantiana da música na KdU. Para Kant (KdU, § 51, B 211), tanto a música como a arte das cores [Farbenkunst] pertencem à arte do belo jogo das sensações. Porém, ele ressalva (B 212): "Não se pode dizer com certeza se uma cor ou um tom (som) [Ton/Klang] são simplesmente sensações agradáveis [angenehme Empfindungen], ou se já é em si um jogo belo de 
Assim, para Hiller a música instrumental desempenha apenas um papel secundário e subordinado à música vocal, que alcança uma maior dignidade e valor artísticos graças à sua união com a poesia. De fato, escreve ele, se compararmos música vocal e instrumental entre si não é difícil decidir qual delas possui a mais alta dignidade [die höchste Würde]:

Palavras e sons, unidos para atingir um mesmo fim [Zweck], constituem o caráter [Charakter] da música vocal, e neste ponto ela supera [übertrifft] todos os instrumentos. [...] Ambas, unidas entre si [...] resultam num tipo de música que se pode chamar, com razão, de a mais perfeita de todas [allervollkommenste]. ${ }^{41}$

Ao se unir às palavras, a música instrumental recebe delas "um significado mais certo e determinado" e, ao mesmo tempo, o poema recebe "um adorno [Zierde] e uma ênfase", que the são dados pelos instrumentos. ${ }^{42}$

Se a união entre música e poesia consegue provocar efeitos tão elevados, o mesmo não pode ser dito da música puramente instrumental, a qual "não se submete tão exatamente à imitação e à expressão das paixões [Ausdruck der Leidenschaften]". ${ }^{43}$ Hiller escreve:

A melodia de um solo ou de um concerto [...] não é tanto um canto imitativo das paixões e do coração, mas antes uma conexão artifical de sons, de acordo com as características do instrumento sobre o qual é tocado [...]. Por meio de tais peças o artista pretende mostrar suas forças e a perfeição de seu instrumento. Ele não procura tanto comover, mas sim, ser admirado. O assombro dos ouvintes é o único aplauso que ele exige. ${ }^{44}$

\footnotetext{
sensações e se como tal traz consigo, no julgamento estético, um comprazimento na forma [Wohlgefallen an der Form]". Também na Antropologia (§ 71) ele afirma que a música "só é arte bela (não simplesmente agradável) porque serve de veículo à poesia" (Cf. KANT, I. Antropologia de um ponto de vista pragmático. Trad. C. A. Martins. São Paulo, lluminuras, 2006, p. 144).

${ }^{41}$ HILLER, J. A. "Abhandlung von der Nachahmung", p. 528.

${ }^{42}$ HILLER, J. A. "Abhandlung von der Nachahmung", p. 529.

${ }^{43}$ HILLER, J. A. "Abhandlung von der Nachahmung", p. 536-37.

${ }^{44}$ HILLER, J. A. "Abhandlung von der Nachahmung", p. 537.
} 
Esse virtuosismo vazio é criticado pelo autor como sendo prova da mais profunda falta de gosto, afetação e barbárie. A música instrumental é vista como algo artificial, que ultrapassa as fronteiras da regularidade e da naturalidade às quais a verdadeira música - a vocal - deve se ater.

Um testemunho posterior, porém, bastante influente acerca do diminuto valor estético da música instrumental gozava nesse período pode ser encontrado em diversos verbetes da Allgemeine Theorie der Schönen Künste ("Teoria Geral das Belas-Artes"), editada por Johann Georg Sulzer. Publicada pela primeira vez em Leipzig, entre os anos de 1771 e 1774, essa foi a primeira enciclopédia em língua alemã a sistematizar e documentar os conhecimentos de estética de meados do século XVIII, sendo um marco importante para a teoria estética entre Baumgarten e Kant. Embora a maior parte dos artigos gerais de estética tenha sido, ao que parece, escrita pelo próprio Sulzer, deve-se lembrar que a elaboração dos artigos técnico-musicais estiveram inicialmente a cargo de Johann Philipp Kirnberger e, num segundo momento, de Johann Abraham Peter Schulz. ${ }^{45}$ No verbete dedicado à música [Musik], há uma hierarquização de seus diferentes gêneros e, também aqui, a música instrumental não ocupa um lugar de grande relevo:

\footnotetext{
45 A esse respeito, ver o "Prefácio" ao segundo volume (1774): "Eu não deteria o leitor aqui com um prefácio, se não me sentisse obrigado a informá-lo que neste volume a maior parte e os mais excelentes artigos acerca da música não são de minha autoria, mas sim [...] de um verdadeiro virtuose. Ele teve a benevolência de tomar para si um trabalho para o qual eu, nem de longe, estava à altura. Dele são, portanto, todos os artigos sobre matérias musicais, desde o início da letra $S$ até o final da obra, com algumas poucas exceções, que eu já havia esboçado anteriormente. Com isso, este volume ganhou um considerável privilégio frente ao anterior. Pois apesar de eu ter tido, para a primeira parte, as lições e a assistência de um dos mais profundos compositores daquela época, a saber, do Sr. Kirnberger, eu não estava, contudo, em condições de expor o que eu tinha a dizer com a profundidade e leveza que só os mestres na arte possuem. Todavia, também neste volume o Sr. Kirnberger, com sua profunda teoria e grande experiência fez, com extraordinária prontidão, muitas e importantes observações a mim e ao Sr. Schultz"' (In: SULZER, Allgemeine Theorie der schönen Künste, 2. Teil, Leipzig: Weidmann, 1774).
} 
Em último lugar colocamos a utilização da música em concertos, que são realizados meramente como passatempo [Zeitvertreib] e para o exercício na execução. Aí incluem-se os concertos, sinfonias, sonatas, solos, que apresentam no geral um ruído [Geräusch] vivo e não desagradável, ou uma tagarelice [Geschwätz] delicada e capaz de entreter, mas que não ocupa o coração. [...] Mas não queremos levar a coisa tão longe como Platão, que condena toda música que não esteja acompanhada pelo canto e pela poesia. Também sem palavras ela pode produzir um efeito, se bem que ela só mostra seu maior efeito quando aplica sua força às obras da poesia. ${ }^{46}$

O autor parece estar bastante ligado à estética do efeito: não se trata, ao que parece, de imitar as emoções, mas de suscitá-las nos ouvintes. Ele não nega que a música puramente instrumental possa causar um certo efeito, mas este é, no entanto, bastante inferior ao da música vocal. A seu ver, a música só atinge seu efeito máximo quando está unida à poesia. Assim, a música genuína não é considerada de maneira autônoma: seu valor e significado não estão nela mesma, nas relações estruturais que os sons possuem entre si, mas na imitação que ela só pode realizar quando se une à poesia: "o mais comovente dueto" ou seja, uma música escrita originalmente para voz - "quando executado [somente] por instrumentos [...] perde, com efeito, a maior parte de sua força". 47

\footnotetext{
${ }^{46}$ Verbete: "Música" [Musik], in: SULZER, Allgemeine Theorie Bd. 2, Leipzig: Weidmann, 1774 , p. 788.

47 Verbete: "Música Instrumental" [Instrumentalmusik], in: SULZER, Allgemeine Theorie Bd. 1, Leipzig: Weidmann, 1771, p. 559.
} 


\section{A crise no paradigma da imitação: Moritz e Smith}

A tradicional concepção da arte como mimesis, que ganhou grande força com as teorias de Batteux em meados do século XVIII, começou a ser colocada seriamente em questão já no final desse mesmo século. Isso trouxe enormes conseqüências no campo da estética musical, tendo contribuído também para o processo de autonomização da música puramente instrumental.

Um primeiro impulso nesse sentido foi dado, sem dúvida, pelos escritos teóricos de Karl Philipp Moritz. ${ }^{48}$ Já no ano de 1785 ele publica o "Ensaio de uma unificação de todas as belas-artes e ciências sob o conceito do consumado em si mesmo": [Versuch einer Vereinigung aller schönen Künste und Wissenschaften unter dem Begriff des in sich selbst Vollendeten]. ${ }^{49}$ Originalmente dedicado ao filósofo Moses Mendelssohn, o ensaio pode ser considerado como sua primeira contribuição para os estudos de estética e teoria da arte e nele encontramos a idéia da obra de arte como algo acabado ou consumado [Vollendet] em si mesmo, idéia esta que constitui um dos fundamentos do pensamento estético do autor.

Moritz inicia o ensaio expondo duas teses geralmente aceitas até então acerca de qual seria o princípio [Grundsatz] comum às belas-artes:

\footnotetext{
48 É importante assinalar que Wackenroder e Tieck foram alunos de Moritz, e participaram dos cursos sobre Estética e História da Arte ministrados por este na Academia de Belas-Artes de Berlin. Cf. a esse respeito: KÖPKE, R. Ludwig Tieck: Erinnerungen aus dem Leben des Dichters. Bd. I. Leipzig: F. A. Brockhaus, 1855, p. 8890; KEMPER, D. Sprache der Dichtung: Wackenroder im Kontext der Spätaufklärung. Stuttgart: Metzler, 1993, p. 51-63. A respeito da influência de Moritz sobre Wackenroder, ver também o artigo de SCHRIMPF, H.-J. "W. H. Wackenroder und K. Ph. Moritz: Ein Beitrag zur frühromantischen Selbstkritik". In: Zeitschrift für deutsche Philologie. Bd. 84 (1964). p. 385-409.

${ }^{49} \mathrm{Cf}$. MORITZ, K. P. "Versuch einer Vereinigung aller schönen Künste und Wissenschaften unter dem Begriff des in sich selbst Vollendeten". In: Berlinische Monatsschrift, 5. Bd., 3. Stück, 1785, p. 225-236.
} 
a primeira das teses afirma que tal princípio fundamental às artes seria a imitação ${ }^{50}$; a segunda tese, por sua vez, afirma que tal princípio seria o prazer ou o agrado [Vergnügen] proporcionado pela obra de arte. Essas duas teses dominantes serão criticadas pelo autor que, por sua vez, procurará estabelecer o conceito de "consumado em si mesmo" como princípio de todas as belas-artes. Em seguida, ele faz uma distinção entre a arte bela, isto é, aquela que tem como finalidade o prazer, e entre a arte mecânica, tem como finalidade a utilidade. Moritz nota, contudo, que encontramos prazer não somente no belo, mas também no útil. Assim torna-se necessário investigar a questão: como distinguir um do outro, ou seja, como distinguir o belo [Schönen] do útil [Nützlich]?

Ora, naquilo que é meramente útil, o prazer não está no próprio objeto, mas no conforto que advém do seu emprego. Em outras palavras, o objeto útil é apenas um meio para alcançar um fim externo a ele. Por isso, no que diz respeito à utilidade, o que importa não é tanto o aspecto externo do objeto, mas sim que ele atinja o fim para o qual foi construído. O objeto útil, portanto, não cumpre (e nem necessita cumprir) a exigência de ser algo consumado em si mesmo, pois, como vimos, ele é apenas um meio, um instrumento para atingir uma finalidade externa [äußern Zweck] a ele. Já por outro lado, argumenta ele, o objeto belo é um todo, consumado em si mesmo e capaz de proporcionar, assim, um prazer mais elevado e desinteressado do que aquele prazer que obtemos com um objeto útil. ${ }^{51}$

50 Embora não o cite expressamente, Moritz tem aqui em vista o famoso e influente
tratado de Charles Batteux Les beaux-arts réduits à un même principe (1746), que
propunha justamente a imitação como sendo o princípio comum a todas as belas-artes.
51 Três anos após a publicação desse ensaio, Moritz publica aquele que é geralmente
considerado como seu texto mais importante: "Sobre a imitação formadora do belo"
(Über die bildende Nachahmung des Schönen, 1788). Moritz retoma e desenvolve aqui
alguns dos temas que já havia abordado em seu primeiro ensaio, como por exemplo, a
distinção entre beleza e utilidade. Segundo ele, um objeto não é belo porque é útil, mas
sim, porque ele não precisa ser útil. Para tanto é necessário que ele seja um todo e, por 
Moritz nota que para a produção [Hervorbringen] de algo útil deve-se ter sempre em vista aquele fim externo, ao qual ele deve visar. A beleza do objeto não precisa necessariamente ser levada em consideração (na medida em que se trata de um objeto útil), pois o mais importante é que ele cumpra o fim a que se destina: um relógio ou uma faca, por exemplo, não precisam necessariamente ser belos aos olhos, desde que cumpram seus objetivos, isto é, respectivamente, que marquem corretamente as horas ou que cortem bem. O útil não possui, portanto, nenhum valor intrínseco, mas possui valor somente na medida em que serve como um meio para alcançar uma finalidade que é externa a ele. Ou seja, o prazer no útil não é um prazer desinteressado e só se origina do fato dele cumprir esse fim externo.

Com o belo se dá exatamente o inverso: ele não possui nenhuma finalidade fora dele mesmo e deve possuir valor em si e por si mesmo. Moritz chama a atenção para a necessidade do reconhecimento do belo [Anerkennung des Schönen] em uma obra de arte e chega até mesmo a afirmar que, quanto maior o reconhecimento do belo, maior valor ele adquire aos nossos olhos Em outras palavras, já está sendo indicada aqui a idéia de que o belo possui uma pretensão à universalidade (numa linguagem kantiana, poderíamos dizer que o julgamento sobre o belo possui uma pretensão ao assentimento de todos). Assim, um juízo sobre o belo não resulta de um julgamento meramente subjetivo, pois se assim o fosse, o julgamento dos outros nos seria completamente indiferente. $\mathrm{Na}$ contemplação do belo atingimos um estado de esquecimento de nós mesmos [Vergessen unsrer selbst]. Como esse belo não possui utilidade externa, não visa a nenhum fim fora de si mesmo, ele será um prazer

isso, o conceito de beleza está intimamente ligado ao conceito de um todo existente por si mesmo [ein für sich bestehendes Ganze]. 
desinteressado. Mais do que isso, o prazer no belo se aproxima do amor desinteressado. ${ }^{52}$

Para que algo seja "consumado em si mesmo" é preciso que eu o tome em consideração como algo que tenha em si mesmo o seu fim. Moritz escreve: "Uma coisa não pode ser bela porque ela nos causa prazer [Vergnügen] - pois senão tudo o que é útil deveria ser belo - mas algo que nos causa prazer sem propriamente ser útil, a isso denominamos belo". ${ }^{53}$ Ao contemplar um objeto belo eu percebo nele uma finalidade interna: o objeto é em si mesmo acabado e, por este motivo ele provoca um prazer desinteressado. E é nesse prazer desinteressado que reside a característica principal do belo. Mas Moritz ressalta que o prazer não é o objetivo principal da obra de arte. Ele é antes uma conseqüência natural dela. ${ }^{54}$ Para ele, seria incorreto afirmar que o objetivo da obra de arte é agradar. Pelo contrário: é justamente porque a obra de arte atingiu o seu fim (interno), e porque a percebemos como consumada em si mesma, é que ela nos agrada. Assim, embora não exclua do belo essa dimensão do prazer [Vergnügen], ele, no entanto, a relativiza: o prazer não é a finalidade última da obra, e sim conseqüência da perfeição interna, do acabamento em si mesma e do desinteresse com que a contemplamos. Tampouco a mera busca do aplauso do público deve ser a finalidade última da obra, pois somente se esta for um todo consumado em si mesmo, é que poderá resistir à prova do tempo. O verdadeiro artista, segundo Moritz, deve sempre buscar a mais alta finalidade interna ou perfeição [die höchste innere Zweckmäßigkeit oder Vollkommenheit]

\footnotetext{
${ }^{52}$ MORITZ, K.P. Schriften zur Ästhetik und Poetik. (Kritische Ausgabe). Tübingen: Max Niemayer, 1962, p. 5.

${ }^{53}$ MORITZ, K.P. Schriften zur Ästhetik und Poetik, p. 6.

${ }^{54}$ Para ele, o prazer [Vergnügen] é um fim subordinado [untergeordneter Zweck], ou antes "somente uma conseqüência natural nas obras das belas-artes". MORITZ, K.P. Schriften zur Ästhetik und Poetik, p. 7.
} 
ao produzir a obra de arte. O aplauso do público é apenas conseqüência. ${ }^{55}$

Como se pode perceber, na teoria estética de Moritz já se antecipam alguns dos principais temas da Terceira Crítica de Kant. Por exemplo, a idéia de que o prazer no belo é um prazer desinteressado, de que o belo possui apenas uma finalidade interna a ele mesmo (Kant dirá: "uma finalidade sem fim"), e de haver uma pretensão à universalidade no julgamento. Além disso, Moritz também aponta uma certa analogia entre 0 belo e a moral (pois também uma ação moral tem seu fim nela mesma). Por outro lado, temos em Kant a importância da subjetividade: o belo não está no objeto, mas no sujeito que julga, ao passo que, em Moritz há uma grande preocupação em determinar o que torna um objeto belo e que características o distinguem de um objeto meramente útil.

Também de grande relevância para a compreensão do processo de autonomização da arte (e, conseqüentemente, também da música) é o artigo "A marca do belo: em que medida as obras de arte podem ser descritas?" [Die Signatur des Schönen: in wie fern Kunstwerke beschrieben werden können? ${ }^{56}$, no qual Moritz procura responder à questão acerca da possibilidade de uma descrição adequada das obras de arte. Tal possibilidade parece-Ihe altamente problemática, e ele chega mesmo a afirmar que as palavras têm que acabar [aufhören] justamente "onde começa a verdadeira obra de arte" ${ }^{57} \mathrm{E}$ nisso consiste, segundo ele,

${ }_{55}$ Cf. MORITZ, K.P. Schriften zur Ästhetik und Poetik, p. 8 .
${ }^{56}$ Publicado inicialmente na "Monatsschrift der Akademie der Künste und mechanischen
Wissenschaften zu Berlin" nos anos de $1788 / 1789$ e republicada em 1793 sob o título
"Die Signatur des Schönen" [A marca do belo].
57 MORITZ, K. P. Schriften zur Ästhetik und Poetik, p. 95. Essa constatação da
inadequação das palavras para descrever a arte irá influenciar profundamente o
pensamento romântico (há ecos dessa idéia em textos de Wackenroder e F. Schlegel,
dentre outros) e prenuncia, de certa forma, o conceito kantiano de "idéia estética" (a
saber, isto é, "aquela representação da faculdade da imaginação [Vorstellung der
Einbildungskraft], que dá muito que pensar, sem que contudo qualquer pensamento
determinado, isto é, conceito, possa ser-lhe adequado, representação que 
a própria essência do belo, a saber, "que ele se explica e se descreve a si mesmo". ${ }^{58}$ Além disso, através de sua forma exterior, o belo "nos revela ao mesmo tempo sua essência interior". ${ }^{59}$ Para Moritz:

As obras das artes plásticas [bildenden Künste] são já a mais perfeita descrição de si mesmas, as quais não podem ser novamente descritas; pois a descrição através de contornos [Konturen] é já em si mesma mais significativa e determinada do que qualquer descrição através de palavras. ${ }^{60}$

Ora, embora ele tenha escrito esse texto tendo em vista principalmente as artes plásticas (como crítica às descrições de esculturas da Antigüidade escritas por Winckelmann), não podemos deixar de notar que essa tese pode ser igualmente aplicada à arte dos sons e, especialmente, à música instrumental pura. E tal aplicação se torna ainda mais importante na medida em que tal tese, ao exigir que a obra de arte seja compreendida em si e por si mesma, abre também uma possibilidade para que a música possa se tornar uma arte autônoma em relação à poesia e fornece material teórico para que a falta de determinação conceitual da música pudesse começar a deixar de ser percebida como uma limitação e como uma característica negativa, para se transformar no traço distintivo mais elevado da música pura.

A influência dessa tese de Moritz transparece ainda em alguns aspectos da teoria da crítica de arte dos alguns autores do Primeiro Romantismo, especialmente na idéia de que o belo só pode ser descrito por meio de palavras se estas também, por sua vez, se transformarem em

conseqüentemente nenhuma linguagem alcança inteiramente nem pode tornar compreensível". Cf. KANT, KdU, § 49)

${ }^{58}$ MORITZ, K.P. Schriften zur Ästhetik und Poetik, p. 95.

${ }^{59}$ MORITZ, K.P. Schriften zur Ästhetik und Poetik, p. 96. Note-se que Hanslick em seu livro "Vom musikalisch-Schönen" defende justamente um conceito de forma musical que nada mais é do que isso: uma forma que é, ao mesmo tempo, o seu próprio conteúdo.

${ }^{60}$ MORITZ, K.P. Schriften zur Ästhetik und Poetik, p. 102. 
uma obra de arte, isto é, por meio da poesia. ${ }^{61}$ Essa idéia também aparece já neste texto de Moritz, quando ele afirma que as palavras não podem descrever o belo enquanto elas mesmas não se transformarem no belo. 62 "Mas isso só pode acontecer", continua o autor, "a partir do ponto em que a verdade cede seu lugar à poesia [Dichtung], e a descrição e o que é descrito se tornam uma só coisa". Assim, na descrição do belo por meio de palavras, é necessário que as próprias palavras se transformem em algo belo: por esse motivo é que "as autênticas [echt] obras da poesia são também a única descrição verdadeira, através de palavras, do belo nas obras das artes plásticas". 63

Daí as suas críticas contundentes a Winckelmann ${ }^{64}$ que, ao tentar uma empreitada já de antemão fadada ao fracasso, acaba por "destruir o todo" da obra de arte. ${ }^{65}$ De fato, ao tentar descrever o belo por meio de palavras acaba-se involuntariamente destruindo a relação entre o todo e suas partes ${ }^{66}$, que é parte indissolúvel da própria essência do belo.

\footnotetext{
${ }^{61}$ Nas Herzensergießungen eines kunstliebenden Klosterbruders de Wackenroder podese encontrar uma tentativa de aplicação desse princípio no ensaio "Zwei Gemäldeschilderungen“.

${ }^{62}$ Entretanto deve-se ter aqui uma certa dose de cautela na leitura desse trecho: não nos parece que o autor esteja se referindo $p$. ex. à descrição de uma estátua através de um poema. Ele apenas constata uma analogia entre ambas as coisas, uma vez que o poema belo, acabado em si mesmo, é da mesma natureza que uma estátua bela, acabada em si mesma. Cf. MORITZ, K.P. Schriften zur Ästhetik und Poetik, p. 100.

${ }^{63}$ MORITZ, K.P. Schriften zur Ästhetik und Poetik, p. 99.

${ }^{64}$ Também em seu livro "Reisen eines Deutschen in Italien in den Jahren 1786 bis 1788" encontram-se críticas a Winckelmann. Cf. p. ex. MORITZ, K.P. Schriften zur Ästhetik und Poetik, p. 244-45.

${ }^{65}$ Cf. também MORITZ, K.P. Schriften zur Ästhetik und Poetik, p. 103.

${ }^{66}$ No capítulo intitulado "Die Grundprobleme der Ästhetik" em Die Philosophie der Aufklärung (Hamburg: Felix Meiner, 2007, p. 360), Ernst Cassirer cita um poema de Goethe que também trata dessa questão.
} 
Outro importante precursor da autonomia da música instrumental pode ser encontrado no ensaio "Da natureza daquela imitação que tem lugar nas chamadas artes imitativas" [Of the nature of that imitation which takes place in what are called the imitative arts], escrito pelo filósofo inglês Adam Smith. ${ }^{67}$ Alguns estudiosos supõem que ele o tenha escrito entre 1751 e 1764; outros, somente depois de $1777 .{ }^{68}$ De todo modo, o ensaio foi publicado somente em 1795, cinco anos após a morte do autor. A primeira tradução desse ensaio para a língua alemã foi publicada já no ano de 1801, no segundo volume de uma coletânea organizada por K. A. Caesar. $^{69}$

$\mathrm{Na}$ segunda parte desse ensaio sobre a imitação nas artes, Smith trata da imitação na música. Ele defende a hipótese de que a primeira música tenha sido vocal, acompanhada por palavras desprovidas de significado. ${ }^{70}$ Assim, a voz humana pode ser considerada como o primeiro instrumento musical utilizado pelo homem, uma vez que essas palavras,

${ }^{67}$ É bastante provável que Smith conhecesse o tratado publicado por James Harris em 1744, no qual a música era tratada como uma arte não propriamente imitativa. (Cf. HARRIS, J. Three treatises: the first concerning art, the second conscerning music, painting and poetry, the third concerning happiness. 4th. Ed. London: C. Nourse, 1783). Entretanto, cabe notar que os resultados de ambos são bastante diferentes, uma vez que Harris valoriza a música principalmente devido à sua capacidade de suscitar os afetos: "a música deriva sua eficácia de uma outra fonte, que não a imitação" (HARRIS, Op. Cit., p. 95), "o genuíno encanto [Charm] da música e os prodígios [Wonders] que ela provoca [...] devem-se não às imitações [...], mas [no fato de] suscitar os afetos [affections]" (HARRIS, Op. Cit., p. 99). Justamente por isso, a música pode atuar como uma grande aliada da poesia, a qual, possui a primazia: "deve-se lembrar que nessa união a poesia sempre terá a precedência, sendo de longe a mais considerável, seja pela sua utilidade, seja pela sua dignidade" (HARRIS, Op. Cit., p. 102).

${ }^{68}$ Cf. SEIDEL, W. „Zählt die Musik zu den imitativen Künsten? Zur Revision der Nachahmungsästhetik durch Adam Smith“. In: FRICKE, J. P. Die Sprache der Musik. Festschrift K.W. Niemöller. Regensburg: Gustav Bosse, 1989, p. 495.

${ }^{69}$ CAESAR, K. A. (Hg). Geist der neuesten Philosophie des In- und Auslandes (3 Bde.). Leipzig: Sommerschen Buchhandlung, 1801. Embora não haja referências a respeito de quem tenha sido o tradutor do texto de Smith (publicado sob o título "Über die Natur der Nachahmung in den nachbildenden Künsten”, p. 182ss.), é altamente provável que ela tenha sido realizada por $\mathrm{C}$. F. Michaelis, cujas contribuições para a estética da música examinaremos com mais detalhe no quinto capítulo deste trabalho.

${ }_{70}$ SMITH, A. "Of the nature of that imitation which takes place in what are called the imitative arts". In: Essays on philosophical Subjects. Indianapolis: Liberty Fund, 1982, p. 187. 
desprovidas de significado, "serviam apenas para auxiliar a voz a formar sons propícios a serem modulados em uma melodia, e a serem alongados ou encurtados de acordo com o tempo e compasso do som". ${ }^{71}$ A poesia teria tido sua origem ao se substituírem essas palavras por outras, portadoras de um significado. Analogamente, a dança pode ter cumprido o mesmo papel de dar sentido e propósito à música. Por isso, ele chama essas três artes de "artes irmãs" [Sister Arts]:

O verso poderia expressar naturalmente algum sentido, que seguia o humor grave ou feliz [...] do som com o qual era cantado; estando ligado e unido àquele som, ele parecia dar sentido e significado àquilo que, de outra forma, não parecia possuir nenhum, ou pelo menos nenhum que pudesse ser clara e distintamente compreendido sem o acompanhamento de uma tal explicação. ${ }^{72}$

Ele observa que apesar de serem artes irmãs, duas delas - música e poesia - poderiam muito bem subsistir sem as outras, sendo a música instrumental aquela que melhor poderia subsistir de maneira autônoma e independente com relação à poesia e à dança. A música vocal, por outro lado, demandaria naturalmente o suporte da poesia, sendo, portanto, uma arte essencialmente imitativa. Ele ressalta que apesar de haver uma enorme disparidade entre a imitação e o objeto imitado, no caso da música vocal são as palavras do poema que explicam e determinam o significado da música. ${ }^{73}$

Se a música vocal, por intermédio das palavras, pode ser considerada uma arte imitativa, o mesmo não pode ser afirmado da música instrumental de modo que, para Smith:

Os poderes imitativos da música instrumental são muito inferiores aos da música vocal; seus sons melodiosos, mas inarticulados e sem significado não podem, tal como as articulações da voz humana, relatar distintamente as circunstâncias de qualquer história particular,

\footnotetext{
${ }^{71}$ SMITH, A. "Of the nature of that imitation", p. 188.

${ }^{72}$ SMITH, A. "Of the nature of that imitation", p. 188.

${ }^{73}$ SMITH, A. "Of the nature of that imitation", p. 191
} 
ou descrever as diferentes situações que essas circunstâncias produziram; ou mesmo expressar claramente, e de forma a ser compreendida por qualquer ouvinte, os sentimentos e paixões que as partes envolvidas sentiram a partir dessas situações: mesmo suas imitações de outros sons [...] são comumente tão indistintas que, sozinhas e sem nenhuma explicação [adicional], não poderiam nos sugerir prontamente [...] o que se pretendia imitar, ou mesmo se se pretendia imitar alguma coisa. ${ }^{74}$

Smith realça sempre essa inaptidão da música instrumental para a imitação: nega que ela consiga imitar uma história em particular, nega que ela consiga expressar com clareza os sentimentos, e afirma que mesmo a imitação de outros sons ou do movimento é feita de maneira bastante insatisfatória pela música instrumental, de modo que sempre seria necessária uma explicação ${ }^{75}$ para que se possa identificar o que ela pretendeu imitar. Entretanto, apesar de considerar que a música instrumental não seja uma arte necessariamente ou essencialmente imitativa, Smith considera que ela pode, mesmo assim, produzir efeitos muito agradáveis, uma vez que "e os principais efeitos que ela é capaz de produzir originam-se de poderes completamente diferentes dos da imitação". 76

Desse modo, não haveria sentido algum em criar embaraços para a melodia e harmonia ou constranger tempo e compasso da música a fim de tentar produzir uma imitação que "provavelmente ninguém irá compreender". Além disso, diz ele, "na melhor música instrumental" (ele cita as aberturas de Händel e os concertos de Corelli) "há pouca ou nenhuma imitação, e onde há alguma, ela é fonte de apenas uma parte

\footnotetext{
${ }_{75}^{74}$ SMITH, A. "Of the nature of that imitation", p. 195.

${ }^{75}$ Essas críticas à capacidade imitativa da música instrumental são contemporâneas à de alguns autores franceses, que começavam também por volta dessa época, a rejeitar a imitação como princípio estético da música (p. ex. Morellet, em 1770; Boyé e Chabanon, em 1779).

${ }^{76}$ SMITH, A. "Of the nature of that imitation", p. 217.
} 
muito diminuta do mérito dessas composições. A música instrumental pode produzir efeitos consideráveis [mesmo] sem nenhuma imitação". ${ }^{77}$

Vale a pena citar na íntegra um trecho um pouco mais longo do ensaio, mas que demonstra de maneira clara a modernidade $e$ originalidade das idéias de Adam Smith sobre a estética da música. Segundo ele:

Um concerto bem-escrito [well-composed] de música instrumental, pelo número e variedade dos instrumentos, pela variedade de vozes [parts] executadas por estes e pela perfeita concordância ou correspondência entre todas essas diferentes vozes; pela exata harmonia ou coincidência de todos os diferentes sons que são ouvidos simultaneamente [...] apresenta um objeto tão agradável, tão grandioso, tão variado e tão interessante que, por si só e sem sugerir qualquer outro objeto, seja por imitação ou por outra forma, pode ocupar [...] completamente a capacidade da mente [...]. Na contemplação daquela imensa variedade de sons agradáveis e melodiosos, arranjados e compilados tanto em sua coincidência [isto é, em sua harmonia] como em sua sucessão [ou seja, em sua melodia], em um sistema tão completo e regular, a mente desfruta não apenas de um grande prazer dos sentidos, mas também de um enorme prazer intelectual, não muito diferente daquele que deriva da contemplação de um grande sistema em qualquer outra ciência. Um concerto completo de tal música instrumental não apenas não requer, como [também] não admite qualquer acompanhamento [de um texto, dança, etc.]. [...] Tal música raramente deseja contar qualquer história, imitar algum evento ou sugerir em geral qualquer objeto em particular, distinto daquela combinação de sons das quais ela é composta. Seu significado, portanto, pode ser considerado completo em si mesmo [complete in itself], e não requer intérpretes para explicá-la. O tema [subject] de tal música [instrumental] é somente [...] uma certa combinação de notas, às quais ela retorna frequentemente, e com as quais todas as suas digressões e variações possuem uma certa afinidade. [...] O tema de uma composição de música instrumental é parte da [própria] composição" ${ }^{78}$

Em resumo, Smith defende a tese de que a imitação não é essencial para a música instrumental: ela pode agradar mesmo não sendo uma arte propriamente imitativa. Mais do que isso - e aí reside a originalidade das

${ }_{77}^{77}$ SMITH, A. "Of the nature of that imitation", p. 203.

${ }^{78}$ SMITH, A. "Of the nature of that imitation", p. 204-205. 
teorias estéticas de Smith sobre a música - ela é capaz de provocar como efeito um prazer altamente intelectual, semelhante ao da contemplação de sistemas científicos. O prazer provocado pela música instrumental não seria, portanto, de natureza meramente sensorial, nem tampouco causado pela sua capacidade de imitação, mas sim, nela mesma, na observação atenta dos sons, dos temas, da instrumentação e da relação de todos esses elementos entre si. Daí resulta sua afirmação da música puramente instrumental como "uma arte que requer todo o julgamento [judgement], conhecimento e invenção do mestre mais consumado", e é nesse julgar que reside o fundamento dos grandes efeitos que ela produz. ${ }^{79}$ Para Smith, o efeito da música é provocado pela melodia e harmonia, e não "por algo outro [que seria] significado ou sugerido por elas: de fato, elas não significam nem sugerem nada [they in fact signify and suggest nothing]" ${ }^{80}$

Dessa forma, Adam Smith reconhece de maneira decisiva a capacidade da música instrumental pura de se dirigir não somente aos sentidos, mas também ao intelecto, e isto não somente mediante uma harmonia fundamentada nas proporções matemáticas dos intervalos e acordes (como acreditava toda a tradição pitagórica, passando por Zarlino, Descartes e Rameau), mas por meio de uma lógica intrínseca ao próprio discurso musical, valorizando os desenvolvimentos temáticos que garantiriam, ao mesmo tempo, que a obra pudesse ser vista como uma unidade, um todo coerente, completo em si mesmo; e não como um amontoado de sons meramente agradáveis ao ouvido, mas incapazes de ocupar o intelecto - justamente aqueles que serão considerados "mais fruição do que cultura", nas palavras de Kant.

\footnotetext{
${ }^{79} \mathrm{SMITH}$, A. "Of the nature of that imitation", p. 201.

${ }^{80} \mathrm{SMITH}, \mathrm{A}$. "Of the nature of that imitation", p. 206.
} 


\section{GÊNIO E ARTE COMO EXPRESSÃO DA SUBJETIVIDADE}

Em seu estudo sobre o problema da irracionalidade na lógica e na estética do século XVIII, Alfred Baeumler aponta a importância do tema da individualidade para o nascimento e consolidação da estética moderna. Baeumler observa que, embora houvesse um pensamento sobre o Belo na Antiguidade e na Idade Média, não se pode dizer que havia uma estética, tal como compreendemos esse termo no sentido moderno, pois "a mera reflexão sobre o Belo não produz nenhuma estética". ${ }^{81}$ Para ele, o que é fundamental no conceito moderno de estética, e que a distingue das filosofias da arte anteriores, está no fato de que ela é definida como uma teoria do gosto.

Mas é preciso notar que é só a partir do estabelecimento de uma nova concepção de homem (que envolve o sentimento, a sensação), que poderá se desenvolver uma teoria do gosto (assim como a idéia de um sujeito estético autônomo, que está na base dessa teoria). Nas palavras de Baeumler, "é somente na esfera estética que o homem é reconhecido enquanto homem, e foi por isso que a individualidade viva só pôde se tornar um objeto do pensamento na época do gosto":.82

O homem estético é um dado último, um fato irredutível, diante do qual, ao que parece, o pensamento tem que capitular. $O$ gosto

81 BAEUMLER, A. Das Irrationalitätsproblem in der Ästhetik und Logik des 18. Jahrhunderts bis zur Kritik der Urteilskraft. Darmstadt: Wissenschaftliche Buchgesellschaft, 1975, p. 2.

${ }^{82}$ BAEUMLER, A. Das Irrationalitätsproblem in der Ästhetik, p. 3. 
anuncia o sujeito [...] em sua liberdade interior mais profunda. Diante do sentimento [Gefühl] todos os critérios externos caem por terra. Quando o gosto [Geschmack] entra em jogo, desaparece todo apoio [Halt] objetivo, o homem se encontra somente diante de si mesmo, e no momento decisivo em que ele se remete a seu sentimento, ele se torna consciente de sua singularidade [Einzigkeit]. Por toda parte ele age segundo normas ou se entrega a um objetivo [Objektiven]. Aqui, o objetivo é apenas uma ocasião para que ele, enquanto este indivíduo, se torne plenamente consciente de si mesmo. Diante do indivíduo, o conceito fracassa [...]. Essa visão [Einsicht] clara da essência da individualidade, que escapa a toda transparência lógica, chama-se irracionalismo. ${ }^{83}$

Baeumler defende a tese de que a principal característica do século XVIII no campo filosófico teria sido não tanto o racionalismo, mas sim o problema do irracional. Esse interesse pelo irracional se exprimiria ao longo de todo o século através do problema do gosto [Geschmack], do sentimento [Gefühl], da faculdade de julgar [Urteilskraft], do espírito [Geist] e do gênio [Genie]. ${ }^{84}$

Com efeito, o problema do gênio foi um dos tópicos fundamentais da estética do período, principalmente a partir de Shaftesbury - como bem mostrou Ernst Cassirer no último capítulo de seu livro Die Philosophie der Aufkärung. Através da análise do gênio, Shaftesbury consegue responder à grave censura platônica contra as artes. Como observa Cassirer, "a arte não é, de maneira nenhuma, mimesis no sentido em que se ateria ao aspecto exterior das coisas" ${ }^{\text {, }}$, tentando meramente reproduzi-la [nachbilden] da maneira mais fiel possível à sua aparência.

Pelo contrário, a concepção que começa a ganhar força a partir daqui - e que exercerá profunda influência sobre a concepção romântica acerca do papel do artista e da arte - é a de que a obra de arte não deve imitar meramente o produto da natureza, mas sim o ato mesmo de produção. Em outras palavras, a arte deve ser criadora. Desse modo,

\footnotetext{
${ }^{83}$ BAEUMLER, A. Das Irrationalitätsproblem in der Ästhetik, p. 3-4.

${ }^{84}$ BAEUMLER, A. Das Irrationalitätsproblem in der Ästhetik, p. 17.

${ }^{85}$ CASSIRER, E. Die Philosophie der Aufklärung. Hamburg: Felix Meiner, 2007, p. 331.
} 
pode-se dizer que a figura do artista enquanto gênio criador opera uma ruptura significativa com uma concepção sobre a arte que a considerava como sendo essencialmente imitativa (seja essa imitação considerada como uma espécie de cópia da realidade; seja como uma imitação dos modelos da Antigüidade).

No caso específico da arte musical, as conseqüências dessa mudança serão consideráveis. Pois se até então a música era tida como uma arte incapaz de levar a cabo o princípio imitativo de maneira totalmente satisfatória, e se a música instrumental era desvalorizada por conta de seu significado obscuro e impreciso, a partir dessa mudança de concepção, a música pura - por não imitar nenhum modelo exterior, criando, por assim dizer, a partir de si mesma - passará a ser considerada justamente como a mais original [das Ursprünglichste] e, por isso mesmo, o modelo ao qual as demais artes deveriam aspirar.

Como se vê, a partir dessa mudança de paradigmas, a idéia da arte como produto de um gênio original irá desempenhar um papel central. No entanto, tal como ocorria com o conceito de imitação, também o conceito de gênio foi interpretado, em diferentes épocas e lugares, das maneiras mais diversas ${ }^{86}$, motivo pelo qual é necessário esboçar, ainda que de maneira breve, os principais traços dessas estéticas do gênio.

De acordo com o estudo de Jochen Schmidt ${ }^{87}$, a "Carta Magna" desse novo pensamento estético que passava a privilegiar o gênio foi escrita por Joseph Addison, já no início do século XVIII. Com efeito, num artigo bastante curto, publicado pela primeira vez no número 160 da

\footnotetext{
${ }^{86}$ A esse respeito, ver o estudo de SCHMIDT, J. Die Geschichte des Genie-Gedankens in der deutschen Literatur, Philosophie und Politik 1750-1945. Bd. 1. Darmstadt: Wissenschaftliche Buchgesellschaft, 1985. Outra obra de referência, mas que abrange um âmbito um pouco mais restrito é: GRAPPIN, P. La théorie du génie dans le préclasscisme allemand. Paris: PUF, 1952. Dentre os livros publicados no Brasil, uma referência fundamental é: SUZUKI, M. O gênio romântico: crítica e história da filosofia em Friedrich Schlegel. São Paulo: lluminuras, 1998.

${ }^{87}$ SCHMIDT, J. Die Geschichte des Genie-Gedankens. Bd. 1, p. XIII.
} 
revista The Spectator (de 03 de setembro de 1711), Addison já definia 0 gênio natural ${ }^{88}$ como o portador de um dom inato, de um fogo e impetuosidade naturais, com as quais ele conseguia criar as obras mais originais e sublimes, sem ter que recorrer à imitação e sem se submeter a nenhuma regra prescritiva. Um outro momento representativo da discussão sobre o gênio no século XVIII está na idéia do "gênio vegetal", tal como descrito por Edward Young em suas Conjectures on Original Composition (1759). De acordo com o excelente comentário de Márcio Suzuki:

\begin{abstract}
Esse texto representa uma mudança profunda na maneira de descrever a produção artística, pois rejeita a idéia de que a criação poética possa ser pensada em analogia com a produção de uma máquina por um artesão. A criação deve antes ser comparada a um organismo, que cresce autonomamente em virtude de sua própria natureza. [...] Como atividade espontânea, a geração de uma obra original prescinde de um modelo a ser imitado, do saber técnico, do trabalho mecânico e até dos materiais prévios necessários para executá-la. É claro que essa descrição também envolve algo mais que a mera alforria do artista em relação ao jugo das regras: capaz de desentranhar um todo perfeitamente ordenado do fundo de sua natureza, o gênio vegetal, se não a soluciona definitivamente, ao menos estabelece novos parâmetros para a analogia entre a produção divina e a atividade criadora do homem. ${ }^{89}$
\end{abstract}

Mas é preciso notar ainda que essa elevação do artista à posição de criador possui também uma dimensão social. No caso da poesia, por exemplo, Schmidt nos lembra que, na sociedade de corte barroca, os poetas estavam em geral ligados a uma corte principesca e eram

\footnotetext{
${ }^{88}$ Os maiores exemplos de gênios desse tipo, segundo Addison, são Homero e Píndaro (dentre os antigos), e Shakespeare (dentre os modernos). Além do gênio natural, Addison menciona ainda uma segunda classe de gênios, a saber, "aqueles que se formaram por regras e submeteram a grandeza de seus talentos naturais às correções e restrições da arte. Tais foram, dentre os gregos, Platão e Aristóteles; dentre os romanos, Virgílio e Túlio, dentre os ingleses, Milton e Sir Francis Bacon". ADDISON, J. The Spectator. Vol. II. London: J. \& R. Tonson, 1744, p. 299.

${ }^{89}$ SUZUKI, M. O gênio romântico, p. 59-60.
} 
dependentes destas, escrevendo para ocasiões determinadas e submetidos a uma autoridade e um sistema de valores exteriores. ${ }^{90}$ Foi somente a partir da consolidação de uma indústria editorial e de um mercado ligado à impressão, distribuição e venda de obras literárias, bem como o crescimento de um público burguês instruído e interessado em livros, que essa situação começou a se modificar e que foi possível o surgimento da figura social do "escritor autônomo", capaz de se manter sem a ajuda de um patrono nobre, somente com a renda dos livros vendidos no mercado. ${ }^{91}$ No caso da música, percebe-se que a situação do compositor e do instrumentista das cortes não era diferente. Segundo o sociólogo alemão Norbert Elias:

Tanto na Alemanha como na França as pessoas que trabalhavam neste campo eram ainda fortemente dependentes do favor, do patronato e, portanto, do gosto da corte e dos círculos aristocráticos [...]. De fato, mesmo na geração de Mozart, um músico que desejasse ser socialmente reconhecido como artista sério e, ao mesmo tempo, quisesse manter a si e à sua família, tinha de conseguir um posto na rede das instituições aristocráticas da corte ou suas ramificações. Não tinha escolha. [...] O que chamamos de corte principesca [Fürstenhof] era, essencialmente, o palácio do príncipe. Os músicos eram tão indispensáveis nestes grandes palácios quanto os confeiteiros, os cozinheiros e os criados, e normalmente tinham o mesmo status que estes na hierarquia da corte. Eles eram o que se chamava, um tanto pejorativamente, de criados de libré. ${ }^{92}$

Como se pode perceber, a profissão de músico manteve, durante muitas décadas, o caráter de um ofício. Em última análise, o compositor era "apenas um subordinado, uma espécie de bem qualificado provedor

\footnotetext{
${ }^{90}$ SCHMIDT, J. Die Geschichte des Genie-Gedankens. Bd. 1, p. 1-2.

${ }^{91}$ ELIAS, N. Mozart: Zur Soziologie eines Genies. Frankfurt a.M.: Suhrkamp, 1993, p. 41. Trad. Bras.: Mozart, a sociologia de um gênio. Trad. S. G. De Paula. Rio de Janeiro: Jorge Zahar, 1994, p. 32.

92 ELIAS, N. Mozart: Zur Soziologie eines Genies, p. 21-22. Trad. Bras.: Mozart, a sociologia de um gênio, p. 17-18.
} 
de entretenimento". ${ }^{93}$ Como bem observou Waizbort, foi somente a partir do momento em que o mecenato deixava de existir, que o compositor tornou-se "empresário de si mesmo, alguém que precisava vender seu produto no mercado dos bens musicais". ${ }^{94} \mathrm{O}$ surgimento da figura do compositor autônomo, que compunha não sob encomenda de um superior hierárquico e para uma ocasião determinada, mas para um público anônimo, pressupõe uma estrutura de edição e comércio de partituras, fabricação de instrumentos, de concertos públicos, etc - já bastante desenvolvida. Ora, essa mudança social foi acompanhada também por uma mudança de estilo ${ }^{95}$. Isso pode ser explicado pelo fato de que a formação do gosto "depende de grupos sociais específicos, que atuam como suportes do gosto, ou seja, como possibilidade de mudanças estilísticas". ${ }^{96}$ Foi assim que a antiga estética racionalista, normativa e baseada em regras rígidas foi sendo aos poucos substituída por uma crescente valorização da expressão subjetiva do artista através de suas obras, nas quais "não é mais uma estrutura fixada por regras a priori, mas os processos internos do criador que estão no centro". ${ }^{97}$

A chamada estética do gênio enfatizava justamente esse aspecto da liberdade criadora com relação às regras. Por volta de 1730 , Gottsched ainda exigia que os autores seguissem os modelos estabelecidos pelo racionalismo francês (nos moldes estabelecidos pela Arte Poética de

\footnotetext{
${ }^{93}$ ELIAS, N. Mozart: Zur Soziologie eines Genies, p. 48. Trad. Bras.: Mozart, a sociologia de um gênio, p. 37.

${ }_{94}$ WAIZBORT, L. "Chaves para ouvir Schumann (paralipomena à Kreisleriana-I)". In: Novos Estudos Cebrap, No. 75, julho 2006, p. 190.

95 "A substituição do Barroco pelo lluminismo e pela Empfindsamkeit não foi somente a substituição de um estilo de época por um outro. A mudança de estilo expressa também a mudança social. Trata-se essencialmente da substituição de uma era de corte por uma era que tende à burguesia". Cf. SCHMIDT, J. Die Geschichte des Genie-Gedankens. Bd. 1, p. 3. A esse respeito, cf. também: ELIAS, N. Mozart: Zur Soziologie eines Genies, p. 59-61. Trad. Bras.: Mozart, a sociologia de um gênio, p. 45-47.

${ }_{96}$ WAIZBORT, L. "Chaves para ouvir Schumann (paralipomena à Kreisleriana-I)". In: Novos Estudos Cebrap, No. 75, julho 2006, p. 188.

${ }^{97}$ SCHMIDT, J. Die Geschichte des Genie-Gedankens. Bd. 1, p. 9.
} 
Boileau), e estabelecia os fundamentos de sua estética na razão e no bom senso, cristalizados através das regras do bom gosto. Para ele, o bom gosto possuía uma função delimitadora para a fantasia e os sentimentos. $^{98}$ Diferentemente de Gottshed, os suíços Bodmer e Breitinger irão defender a figura do gênio enquanto criador livre e autônomo, e não mais limitado pelas regras da razão ou do bom-gosto.

Influenciados pelas teorias de Dubos, Bodmer e Breitinger concederam uma posição elevada ao maravilhoso e ao sublime e, com isso, exerceram grande influência sobre poetas como Klopstock $^{99}$, cujos poemas bíblicos concedem um lugar maior ao supra-sensível (que não pode ser objeto da imitação da natureza). Com isso, a faculdade da imaginação - concebida como a capacidade produtiva da fantasia também adquire uma posição mais elevada. Com isso, os conceitos de imaginação e de fantasia - que, para Gottsched deveriam ser limitados pela racionalidade - adquirem uma significação muito maior a partir de Bodmer e Breitinger, tornando-se centrais para a discussão estética.

Aliás, a imaginação passa a ser considerada como a faculdade fundamental do gênio, que cria autonomamente a partir dela. ${ }^{100}$ Além da valorização da subjetividade em seu aspecto criador, esses autores salientaram a importância do efeito emocional provocado pela poesia. Enquanto Gottsched considera perigoso que o poeta se entregue aos afetos e exige uma estrita orientação racional, Bodmer e Breitinger exigem que o poeta possua uma maneira de escrever capaz de comover - coração [hertzrührende Schreibart]. Para eles, a poesia deve, principalmente, suscitar sentimentos [Gefühle erregen] e, para alcançar esse fim, é preciso que o próprio poeta esteja tomado pelo sentimento

\footnotetext{
${ }^{98}$ Cf. SCHMIDT, J. Die Geschichte des Genie-Gedankens. Bd. 1, p. 19-22.

${ }^{99}$ Cf. SCHMIDT, J. Die Geschichte des Genie-Gedankens. Bd. 1, p. 47-48.

${ }^{100}$ Cf. SCHMIDT, J. Die Geschichte des Genie-Gedankens. Bd. 1, p. 49-51.
} 
que pretende suscitar nos leitores. ${ }^{101}$ Mais do que uma mera elaboração técnica guiada pelos preceitos e regras da Retórica, a poesia passa a ser entendida como uma criação guiada pelo sentimento do poeta. ${ }^{102}$

Deve-se observar que essas concepções acerca da criação e do efeito da poesia influenciaram também o pensamento estético-musical da época. Um exemplo significativo pode ser encontrado no Versuch über die wahre Art, das Clavier zu spielen [Ensaio sobre a verdadeira forma de se tocar teclado], publicado em 1753 por C. P. E. Bach. No capítulo dedicado à interpretação [Vom Vortrag], ele afirma:

Uma vez que um músico não pode comover [rühren] ninguém se ele próprio não estiver comovido, então ele deve, necessariamente, poder colocar-se em todos os afetos que ele deseja suscitar em seus ouvintes; dessa forma ele comunica os seus sentimentos [Empfindungen] e move [seus ouvintes] da melhor maneira para que sintam com ele. ${ }^{103}$

Nesse trecho está documentada uma transformação importante para a estética da música do período: a expressão dos sentimentos subjetivos

\footnotetext{
${ }^{101}$ Cf. SCHMIDT, J. Die Geschichte des Genie-Gedankens. Bd. 1, p. 48. Deve-se notar que essa exigência, de certa forma, já estava presente em importantes autores da Antigüidade, nos quais se relacionava com o decoro e a conveniência. Na Arte Poética de Horácio (102-107) lemos: "Se queres que eu chore, tu mesmo deves sofrer por primeiro, então, ó Télefo ou Peleu, os teus infortúnios me tocarão. [...] Palavras tristes convêm a rosto pesaroso; ao rosto irado convém palavras carregadas de ameaça [...]" (Cf. TRINGALI, D. A Arte Poética de Horácio. São Paulo: Musa, 1993, p. 29). Também em Quintiliano (Inst. Oratoria) e Cícero (De Oratore) podem ser encontrados exemplos semelhantes (Cf. ABRAMS, M. H. The mirror and the lamp: romantic theory and the critical tradition. N. York: Oxford Univ. Press, 1971, p. 70-72). Abrams (Op. Cit., p. 72) nota ainda que, também em Longino, as emoções desempenham um papel importante dentre as fontes do sublime. Com efeito, as duas primeiras fontes do sublime enumeradas por Longino são: 1) a faculdade de lançar-se aos pensamentos elevados; 2) a paixão violenta e criadora de entusiasmo (Cf. LONGINO, Do Sublime. Trad. F. Hirata. São Paulo: Martins Fontes, 1996, p. 52).

${ }_{102}$ Cf. SCHMIDT, J. Die Geschichte des Genie-Gedankens. Bd. 1, p. 58.

${ }^{103} \mathrm{BACH}$, C. P. E. Versuch über die wahre Art, das Clavier zu spielen Bd. 1. Berlin: C. F. Henning, 1753, p. 122
} 
do intérprete através da música. Num artigo ${ }^{104}$ que se transformou em referência a respeito do conceito de expressão na música do Sturm und Drang, o musicólogo Hans-Heinrich Eggebrecht chama a atenção para o fato de que "que o pensamento (comum até os dias de hoje) de exprimir a si mesmo na música só surgiu a partir do século XVIII". ${ }^{105}$ Segundo a concepção tradicional, a afirmação de que a música deveria exprimir algo [etwas ausdrücken], era interpretada no sentido de que sua finalidade "imitar, pintar, descrever ou representar algo"106, e não os sentimentos pessoais do compositor. Estamos, portanto, ainda no âmbito da concepção de música enquanto imitação. Da mesma forma, a exigência de que a música deveria representar afetos determinados estava ligada à retórica e à doutrina das figuras [Figurenlehre], e não à expressão dos sentimentos pessoais do compositor através da obra de arte musical. ${ }^{107}$

Por outro lado, no Sturm und Drang a palavra "expressão" adquire um significado bastante diverso, buscando-se acentuar não a convencionalidade das regras e do vocabulário retórico-musical, mas sim, "a expressão da subjetividade do compositor e do intérprete". ${ }^{108}$ Como observa Eggebrecht:

Em lugar da representação objetiva dos Afetos, entra em cena a exigência de que o compositor precisaria colocar-se a si mesmo no afeto [sich selbst in den Affekt setzen], de início somente 'de certa forma', "como se se estivesse de fato devoto, apaixonado,

\footnotetext{
${ }^{104}$ EGGEBRECHT, H.H. "Das Ausdrucks-Prinzip im musikalischen Sturm und Drang". Deutsche Vierteljahrsschrift für Literaturwissenschaft und Geistesgeschichte. Vol. 29, 1955, p. 323-349.

${ }_{105}$ EGGEBRECHT, H.H. "Das Ausdrucks-Prinzip“, p. 348.

${ }^{106}$ EGGEBRECHT, H.H. "Das Ausdrucks-Prinzip", p. 330-331.

107 Como bem observou Carl Dahlhaus, "o modo de falar convencional do século XVII e do princípio do século XVIII de que o objetivo [Zweck] da música seria affectus exprimere seria mal-entendido se se falasse de 'expressão' [Ausdruck] e se pensasse na manifestação dos sentimentos [Gefühlsregungen] do compositor ou do intérprete. Os afetos eram representados, retratados, mas não 'extraídos da alma', arrancados do íntimo agitado". DAHLHAUS, C. Musikästhetik. Köln: Hans Gerig, 1967, p. 31.Trad. Port. Estética Musical. Trad. A. Morão. Lisboa: Ed. 70, 1991, p. 32.

${ }^{108}$ EGGEBRECHT, H.H. "Das Ausdrucks-Prinzip", p. 330.
} 
enfurecido" (Mattheson), como se [als ob] o próprio compositor sentisse a paixão [...]: "como um ator" (Marpurg); e depois sempre de maneira mais efetiva [...]: "pois um músico não pode comover ninguém se ele mesmo não estiver comovido (C.P.E. Bach); [...] "o artista só pode representar o que ele mesmo sente" (Reichardt); [...] "é impossível exprimir sentimentos que a própria pessoa não possua" (Sulzer, Verbete: Leidenschaft). ${ }^{109}$

Mas essa passagem de uma estética da representação dos afetos para uma estética da expressão traz consigo a possibilidade de uma valorização da indeterminação [Unbestimmtheit] característica da música, o que permitirá que a música instrumental "pouco a pouco não seja mais considerada como mera imitação do canto, mas que logo obtenha o primeiro lugar" na hierarquia dos gêneros musicais. ${ }^{110}$ Além disso, ao se valorizar a música como linguagem imediata do coração, a sinceridade do artista passará a ser um critério para o julgamento das obras. Mais do que a conformidade da obra musical a regras agora tidas como "mecânicas", o que mais importante passará a ser a expressão imediata das emoções através da música.

${ }^{109}$ EGGEBRECHT, H.H. "Das Ausdrucks-Prinzip", p. 335.

${ }^{110}$ EGGEBRECHT, H.H. "Das Ausdrucks-Prinzip", p. 336. 


\title{
III. WACKENRODER, TIECK E A IDÉIA DE UMA RELIGIÃO DA ARTE
}

\begin{abstract}
"A arte tem uma origem ideal, pode-se dizer que ela nasceu da religião e com a religião". ${ }^{11}$
\end{abstract}

O "primeiro manifesto" do Romantismo alemão, na opinião de alguns comentadores $^{112}$, encontra-se num livro relativamente curto, publicado anonimamente em Berlim no final de 1796 (já com a indicação de 1797). Seu título: Herzensergießungen eines kunstliebenden Klosterbruders [Efusões do coração de um monge amante da arte]. Escrito por Wackenroder e Tieck $^{113}$, o livro consiste basicamente numa série de ensaios, principalmente sobre a pintura e a música, a relação entre arte e religião, o problema do gênio e o tema da inadequação do artista ao

${ }^{111}$ GOETHE, J. W. Escritos sobre arte. Trad. M. A. Werle. São Paulo: Humanitas, 2005, p. 194.

${ }^{112}$ Cf. por exemplo: STRACK, F. "Die 'göttliche' Kunst und ihre Sprache. Zum Kunst- und Religionsbegriff bei Wackenroder, Tieck und Novalis". In: BRINKMANN, R. (Hg.). Romantik in Deutschland. Stuttgart: Metzler, 1978, p. 369-391; e também: ALEWYN, R. Wackenroders Anteil. In: Germanic Review, 19:1 (1944), p. 48-58.

113 A questão da autoria de cada ensaio é, ainda hoje, controversa entre os comentadores. De acordo com o Prof. Silvio Vietta (WACKENRODER, HKA I, p. 287), Wackenroder seria o autor dos textos: Raphaels Erscheinung, Der merkwürdige Tod des...Francesco Francia, Der Schüler und Raphael, Das muster...Leonardo da Vinci, Zwei Gemäldeschilderungen, Einige Worte über Allgemeinheit..., Ehrengedächtniß...Albrecht Dürers, Von zwei wunderbaren Sprachen..., Von den Seltsamkeiten des alten Malers..., Wie und auf welche Weise man die Werke der großen Künstler, Die Größe des Michelangelo, Die Malerchronik, Das merkwürdige musikalische Leben des Tonkünstlers Joseph Berglinger. Da autoria de Tieck seriam: An den Leser dieser Blätter, Sehnsucht nach Italien, Ein Brief des jungen Florentinischen Malers..., Brief eines jungen deutschen Malers, Die Bildnisse der Maler. 
mundo prosaico. Em 1799, cerca de um ano após a morte prematura de Wackenroder (falecido em fevereiro de 1798), Tieck editou uma espécie de continuação desse livro, desta vez com um número maior de textos de sua autoria, ao qual deu o título de Phantasien über die Kunst [Fantasias sobre a arte]. ${ }^{114}$ Também aqui, encontramos novamente a figura do monge-narrador e os mesmos temas presentes no livro anterior. É bastante provável que o tom de devoção religiosa adotado pelo narrador tenha contribuído para o surgimento das interpretações que consideram os textos de Wackenroder como produtos de um diletante ingênuo e sem maiores ambições teóricas. Nada mais longe da realidade: ambos os livros contêm reflexões teóricas importantes e, de fato, não é exagero considerá-los como o primeiro manifesto do movimento romântico, pois, embora não se possa afirmar que esses textos tenham surgido como uma resposta direta às questões colocadas pela filosofia de Kant ${ }^{115}$ e Fichte (tal como ocorreu no chamado "Círculo de Jena"), sua influência pode ser

114 De acordo com Vietta (In: WACKENRODER, HKA I, p. 371), seriam da autoria de Tieck: Prefácio, Eine Erzählung..., Rafael's Bildniß, Das jüngste Gericht..., Watteau's Gemälde, Über die Kinderfiguren..., Ein paar Worte über Billigkeit..., Die Farben, Die Ewigkeit der Kunst, Unmusikalische Toleranz, Die Töne, Symphonien, Der Traum. De autoria de Wackenroder seriam: Schilderung wie die alten deutschen Künstler..., Die Peterskirche, Vorerinnerung, Ein wunderbares morgenländisches Märchen, Die Wunder der Tonkunst, Von den verschiedenen Gattungen..., Fragment aus einem Briefe Joseph Berglingers, Das eigentümliche innere Wesen der Tonkunst, Ein Brief Joseph Berglingers.

115 Pode-se supor, contudo, que Wackenroder e Tieck tivessem contato com a filosofia de Kant por intermédio de Reichardt. Que a filosofia de Kant não lhes era inteiramente alheia, é o que se pode depreender também de um relato de Tieck acerca de uma viagem a Jena. Numa carta à sua irmã, datada de 02 de maio de 1793, Tieck menciona uma discussão sobre a filosofia de Kant e se refere a Reinhold em termos bastante elogiosos: "Fomos de Drakendorf a Jena a pé, a fim visitar diversas pessoas. Reinhold (penso que tu és ignorante o suficiente para não o conhecer: ele é o primeiro dentre os kantianos, um homem a quem venero quase tanto quanto Schiller) foi nossa primeira visita. Ele é um homem excelente e, sem querer ser pretencioso, logo ficamos bons amigos [...]. Gostaria de vir estudar em Jena, para pode ouvir suas aulas" (In: WACKENRODER, HKA II, p. 248). No entanto, como não há nenhuma referência direta à filosofia de Kant, seja nos Herzensergießungen, seja nas Phantasien, optamos por situá-los antes do capítulo dedicado à recepção da filosofia kantiana, assumindo a mesma perspectiva adotada por Dirk Kemper, que se concentra mais na ruptura e superação de outros filósofos do século XVIII, como Sulzer e Ramler. 
verificada em textos de August e Friedrich Schlegel ${ }^{116}$, Schleiermacher, Schelling e Hoffmann, entre outros.

A amplitude dos interesses teóricos de Wackenroder e Tieck está documentada em suas cartas dos anos de 1792 e 1793. Em diversas passagens há menções a Longino, Shakespeare, Ossian, Hamann, Reinhold, Goethe, Lessing, Schiller, Diderot, Heinse, Winckelmann, Lairesse, Dubos e Sulzer. Além disso, os dois eram freqüentadores assíduos da residência do compositor J. F. Reichardt ${ }^{117}$, assistiram aos cursos de estética e história da arte dados por K. P. Moritz ${ }^{118}$ na Academia de Belas-Artes de Berlim, e foram alunos de Forkel (História da Música) na Universidade de Göttingen. ${ }^{119}$ A influência desses autores pode ser percebida em diversos temas abordados nos textos de Wackenroder e Tieck.

A idéia de que a arte é uma espécie de linguagem elevada e de origem sagrada - que será um dos temas centrais da "religião da arte" de Wackenroder e Tieck - aparece já em 1782 num artigo escrito por Reichardt e publicado no primeiro volume da Musikalisches Kunstmagazin:

\footnotetext{
${ }^{116}$ De acordo com Ernst Behler, a influência de Wackenroder sobre o círculo dos Primeiros Românticos de Jena manifestou-se, sobretudo no interesse pela pintura, "no diálogo Os Quadros de August e Caroline Schlegel, nas descrições de pinturas realizadas por Friedrich Schlegel em Europa, e no lugar de destaque que a pintura alcançou na teoria da arte do Romantismo tardio". BEHLER, E. "Wackenroder y la concepción musical del Primer Romanticismo". In: Anuário Filosófico 29 (1996), p. 27.

${ }^{117}$ Há testemunhos, inclusive, de que Wackenroder teria tido aulas de composição com Reichardt. (Cf. WACKENRODER, HKA II, p. 436). Cabe lembrar ainda que Wackenroder estudou música também com Fasch e Zelter (Cf. TADDAY, U. "Und ziehe mich still in das Land der Musik, als in das Land des Glaubens, zurück: Zu den pietistischen Grundlagen der Musikanschauung W. H. Wackenroders". In: Archiv für Musikwissenschaft 56, Heft 2 (1999), p. 106).

118 Cf. HUBERT, U. Karl Philipp Moritz und die Anfänge der Romantik. Frankfurt a.M.: Athenäum, 1971, p. 26.

${ }_{119}$ Cf. BEHLER, E. "Wackenroder y la concepción musical del Primer Romanticismo". In: Anuário Filosófico 29 (1996), p. 25.
} 
A origem e a finalidade [Zweck] da arte é sagrada [heilig], de maneira sagrada ela é também exercida. [...] Toda arte elevada nasceu da elevação da alma humana acima dessa vida terrena. Toda arte elevada era, no princípio, linguagem dos homens com os deuses [...]. Assim a arte sempre foi filha dos mais altos e nobres sentimentos. ${ }^{120}$

Reichardt foi também um importante defensor da tese segundo a qual a finalidade última da música seria "comover o coração [das Herz rühren], despertar e acalmar as paixões". ${ }^{121}$ Mas, a seu ver, não seria suficiente que a música apenas se limitasse a suscitar sentimentos: seria preciso que ela ocupasse também o entendimento [Verstand], e isto se daria principalmente por meio da harmonia. Assim, uma parte fundamental do prazer musical deveria ser proporcionada pela atividade do entendimento. É nessa exigência que se fundamentam as críticas aos "diletantes" [Liebhaber], que desejam apenas desfrutar sensações agradáveis, "ser embalados docemente" pela música, e não se interessam por essa ocupação do entendimento [Beschäftigung des Verstandes]. ${ }^{122}$

No que concerne ao valor e papel da música instrumental, ele defende que a música possa ser um deleite [Ergötzung] "em si mesma, enquanto música, sem que ela tenha que imitar sentimentos e paixões". ${ }^{123}$ Mas não se trata de algo meramente agradável aos sentidos: mais do que uma mera mistura agradável de sons, a música pode também ocupar o intelecto por meio das variadas relações dos sons entre si, dando origem a uma espécie de deleite mais nobre. $\mathrm{E}$ as duas coisas - o prazer sensível encontrado pela combinação agradável dos sons e a ocupação do intelecto - quando unidas, seriam a causa, segundo ele, do prazer

\footnotetext{
120 REICHARDT, J. F. Briefe, die Musik betreffend: Berichte, Rezensionen, Essays.Leipzig: Reclam, 1976, p. 110-11.

${ }^{121}$ REICHARDT, J. F. Briefe, die Musik betreffend, p. 71.

${ }^{122}$ REICHARDT, J. F. Briefe, die Musik betreffend, p. 74. Essa mesma crítica será feita também por Hoffmann e Hanslick - sendo que, no caso deste último, utilizando-se de termos bastante similares aos de Reichardt.

${ }^{123}$ REICHARDT, J. F. Briefe, die Musik betreffend, p. 133-34.
} 
[Vergnügen] que encontramos na música meramente instrumental, mesmo que ela "não expresse nenhum sentimento ou paixão determinados". ${ }^{14}$ Por outro lado, de maneira semelhante a Hiller, ele condena aquelas obras em que se privilegie somente um virtuosismo vazio e o efeito fácil em detrimento de um conteúdo artístico e musical mais consistente. Para ele, o virtuosismo vazio é uma mera afetação [bloße Künstelei], "um Hokuspokus prodigioso" sem valor musical, e que suscita a admiração dos ouvintes graças unicamente às enormes dificuldades técnicas de execução. ${ }^{125}$

Um outro tema central nos escritos de Wackenroder e Tieck diz respeito à valorização da "obscuridade" da música instrumental, bem como a tese segundo a qual a suposta falta de clareza conceitual da música seria sua maior qualidade, que a elevaria muito acima da linguagem das palavras. A valorização da música enquanto uma "linguagem dos sentimentos" [Sprache der Empfindungen] superior à linguagem dos conceitos ${ }^{126}$ aparece já em 1778 num artigo publicado por J. N. Forkel ${ }^{127}$ na Musikalisch-Kritische Bibliothek. ${ }^{128}$ Para ele, embora a

\footnotetext{
${ }^{124}$ REICHARDT, J. F. Briefe, die Musik betreffend, p. 134.

${ }^{125}$ REICHARDT, J. F. Briefe, die Musik betreffend, p. 118-119. Essa crítica aos virtuoses e à busca de efeito fácil na música é um tema que reaparece em vários autores posteriores como, por exemplo, em Wackenroder (no texto sobre a vida de Joseph Berglinger), e também em Hoffmann (na Kreisleriana, e em especial em "Johannes Kreisler, des Kapellmeisters, musikalische Leiden" e em "Nachricht von einem gebildeten jungen Mann").

${ }_{126}$ FORKEL, J. N. Musikalisch-Kritische Bibliothek. Erster Bd. Hildesheim: G. Olms, 1964 (Reprographischer Nachdruck der Ausgabe Gotha 1778), p. 66.

${ }^{127}$ A respeito da influência de Forkel nos escritos de Wackenroder, cf: VIETTA, S.; KEMPER, D. Wilhelm Heinrich Wackenroder im Spiegel der Quellenforschung und Editionsgeschichte: Katalog zur Ausstellung der Universitätsbibliothek Hildesheim vom 28. April bis 28. Mai 1993. Lamspringe : Quensen, 1993.

${ }^{128}$ Forkel retoma esse ponto de vista também na "Introdução" à sua História Geral da Música, publicada dez anos mais tarde. Ali ele faz uma distinção entre uma linguagem do entendimento [Sprache des Verstandes], que é a linguagem das palavras; e uma linguagem do coração [Sprache des Herzens], que é a música. Cf. FORKEL, J. N. Allgemeine Geschichte der Musik I. Leipzig: Schwickert, 1788, p. 2. De acordo com os registros da biblioteca da Universidade de Göttingen, Wackenroder emprestou esse livro de Forkel em 01.02.1794. Cf. WACKENRODER, HKA II, p. 653.
} 
música não possua um grau de clareza [Deutlichkeit] suficiente para que se consiga traduzi-la em palavras, Forkel irá considerar essa "obscuridade" da música instrumental não como uma deficiência, mas sim, como uma característica positiva, uma vez que a música só começaria a ser uma linguagem dos sentimentos a partir do ponto "onde as outras linguagens não são mais suficientes, onde acaba sua capacidade de expressão". ${ }^{129}$

Essa idéia da música como uma linguagem dos sentimentos pode ser encontrada também no romance Andreas Hartknopf. Eine Allegorie ${ }^{130}$, de Karl Philipp Moritz. No capítulo intitulado "Hartknopfs Gesellenjahre" há uma passagem bastante significativa nesse sentido:

"Hartknopf tirou do bolso a sua flauta e acompanhou, com os acordes adequados, o maravilhoso recitativo de seus ensinamentos. Enquanto fantasiava [phantasierte] ele traduzia a linguagem do entendimento [Sprache des Verstandes] para a linguagem dos sentimentos [Empfindungen]: pois, para isso Ihe servia a Música". ${ }^{131}$

Temos aqui a música instrumental caracterizada como uma linguagem elevada, capaz de traduzir a linguagem do entendimento em linguagem dos sentimentos e, dessa forma, capaz não apenas de agir sobre as paixões do ouvinte, mas de trazer à tona o inefável, de expressar de maneira imediata aquilo que está além do poder de expressão das palavras. Aliás, a superioridade da música enquanto linguagem é tão grande, que esta Ihe parece ser o modo mais adequado de expressar de maneira clara mesmo aquelas idéias que, por meio da linguagem das palavras, só se poderiam ser expressas de maneira obscura e confusa, como se pode perceber na seguinte passagem: "Ele executou algumas idéias confusas [verworrene Idee] ao piano, trazendo-

\footnotetext{
${ }^{129}$ FORKEL, J. N. Musikalisch-Kritische Bibliothek, p. 67.

130 Publicado em 1785, porém com a indicação de ano de 1786. Uma continuação do romance foi publicada em $1790 \mathrm{com}$ o título Andreas Hartknopfs Predigerjahre.

${ }^{131}$ MORITZ, K.P. Andreas Hartknopf. Eine Allegorie. Berlin: Unger, 1786, p. 131.
} 
as à claridade [ins klare gebracht] "132. Nesse romance, a principal qualidade da música instrumental - isto é, na linguagem dos sentimentos - estaria no fato de manter o todo [Ganze] intacto, preservando inteiramente sua abundância [Fülle], pois, diferentemente dos sons articulados da fala, os sons inarticulados da música "não despedaçam [zerstücken] o todo, para depois o reagrupar". ${ }^{133}$ Mesmo no caso da música vocal, não é a poesia, mas sim a melodia que ocupa a posição mais importante: pois é só ela que fala "a linguagem dos sentimentos [Sprache der Empfindungen], que as palavras não conseguem expressar [nicht auszudrücken vermögen]". ${ }^{134}$ É através dessa linguagem dos sentimentos que a música consegue expressar um extenso campo [Gebiet] de idéias que estão fora dos limites da linguagem [außer den Grenzen der Sprache]. ${ }^{135}$

\section{Desabafos e fantasias de um monge amante da arte}

Os textos de Wackenroder e Tieck são presença constante nos livros que abordam a estética musical do Primeiro Romantismo. No entanto, uma questão que pode ser levantada com relação a muitos desses estudos diz respeito ao fato de não se levar em consideração que, tanto os Herzensergießungen quanto as Phantasien fazem parte de um conjunto ficcional. Embora o excelente livro editado no final dos anos 60 por Elmar Hertrich - o qual, no entanto, aborda somente o personagem Joseph Berglinger - constitua uma exceção, pode-se dizer que a grande maioria dos historiadores se contentou apenas em citar uma ou outra passagem - isolada do seu contexto original - para sustentar as suas

\footnotetext{
${ }_{132}$ MORITZ, K.P. Andreas Hartknopf, p. 131.

${ }^{133}$ MORITZ, K.P. Andreas Hartknopf, p. 131-32.

134 MORITZ, K.P. Andreas Hartknopf, p. 71.

${ }^{135}$ MORITZ, K.P. Andreas Hartknopf, p. 71.
} 
hipóteses, confundindo, no mais das vezes, autor e personagem e sem levar em conta o contexto literário mais amplo do qual essas citações fazem parte. Desse modo, uma pergunta que deveria ser colocada logo de início é: até que ponto as idéias expressas pelo monge-narrador ou pelo personagem de Joseph Berglinger realmente refletem as opiniões e os pontos de vista de Wackenroder e de Tieck enquanto autores? Sem querer solucionar definitivamente essa questão, examinaremos aqui alguns dos principais temas tratados nos dois livros publicados por Wackenroder e Tieck através de uma dupla perspectiva: levando em consideração, sempre que possível, as questões estéticas abordadas na correspondência de ambos dos anos de 1792/93 e, além disso, procurando ter sempre em vista a dimensão literária em que os problemas filosóficos abordados estão inseridos.

Um primeiro aspecto a ser considerado é a figura do mongenarrador - que estará presente em ambos os livros - e aparece já no prefácio das Herzensergießungen. A escolha desse monge amante da arte como narrador, além de dar unidade à obra como um todo, traz consigo conseqüências importantes para a maneira de se abordar as questões estéticas no livro. A principal conseqüência é, sem dúvida, a determinação de uma certa perspectiva a respeito da arte, que será marcada notadamente por sua proximidade com a religião. A peculiaridade da linguagem empregada pelo narrador, impregnada de devoção perante a arte, não passou desapercebida aos primeiros leitores. August Schlegel, que publicou uma recensão do livro em fevereiro de 1797 no Allgemeine Literatur-Zeitung comentou a esse respeito:

Nós o compreendemos e podemos traduzir facilmente a sua linguagem para o nosso modo de falar. Além disso, justamente por ser antiquada, essa linguagem possui o atrativo [Reiz] da novidade. Por mais que o livre jogo da imaginação [freien Spiele der Einbildungskraft], em que consiste a fruição da arte [Kunstgenuss], 
pareça essencialmente distinto daquela devoção [Andacht] [...], é, contudo, inegável, que a arte mais recente [...] possui um vínculo muito estreito com a religião. ${ }^{136}$

Ao tomar a arte como algo sagrado, o narrador considera que o artista - o gênio - recebe seu talento como dádiva divina, e a inspiração é imprescindível para a criação da verdadeira obra de arte. Essa visão a respeito da arte irá determinar, ao mesmo tempo, a postura do público (que deve ser marcada pela devoção e recolhimento perante a obra de arte) - e também do crítico de arte (pois, uma vez que a linguagem das palavras é insuficiente para apreender o divino da arte, teremos como conseqüência que uma obra de arte só pode descrita através de uma outra obra de arte).

Escritos na solidão da vida monástica, os textos teriam nascido não de um esforço teórico ou sistemático, mas de um "ímpeto interior" do narrador, desejoso de expressar a divindade da arte. Por isso mesmo, ele irá combater tanto a concepção que considera a arte como mero prazer dos sentidos, como também a concepção racionalista daqueles teóricos que abordam a arte com um olhar "crítico e frio", como Ramdohr, por exemplo. As crônicas sobre as vidas de grandes pintores do Renascimento italiano (Rafael, Michelangelo, Leonardo) e alemão (Dürer), que ocupam quase toda a primeira parte do livro, adotam, em certos momentos, um tom similar ao de uma hagiologia. Se a arte possui origem divina, esses grandes mestres seriam os "santos" da arte [Kunstheiligen].

O primeiro ensaio, intitulado "Raphaels Erscheinung" [A visão de Rafael] aborda o tema da inspiração [Begeisterung] do gênio. Já de início, ao constatar que o tema da inspiração dos poetas e artistas sempre foi um grande objeto de litígio, ele nomeia os seus dois adversários. Em primeiro lugar, o vulgo, que tem a esse respeito idéias absolutamente ${ }^{136}$ In: WACKENRODER, HKA I, p. 419. 
equivocadas e desconhece que a inspiração é uma revelação [Offenbarung] interior dos gênios da arte. Em segundo lugar, ele irá se opor aos teóricos e sistemáticos que, sem conhecer a verdadeira natureza da inspiração do artista, descrevem-na apenas "de ouvir falar" e, com seu falatório profano, tentam delimitar através das palavras o espírito e o significado daquilo que não se deixa apreender em palavras [der sich in Worte nicht fassen läßt]. ${ }^{137}$

Eles falam da inspiração do artista como de uma coisa que eles teriam sob os olhos; eles a explicam e contam muitas coisas a seu respeito. Mas deveriam se envergonhar em pronunciar a palavra sagrada, pois eles não sabem o quê estão falando.

Dentre esses "pseudo-sábios", os piores são os incrédulos, "que zombam e negam totalmente com risos sarcásticos a inspiração celestial da arte":

Eles arruínam os jovens ânimos de seus discípulos ao ensiná-los opiniões tão temerárias e irresponsáveis sobre coisas divinas, tal como se elas fossem humanas, e com isso implantam neles a loucura, como se estivesse no poder deles tomar aquilo que os maiores mestres da arte só alcançaram por inspiração divina [göttliche Eingebung]. ${ }^{138}$

A tese da inspiração divina do artista é demonstrada através do exemplo de Rafael. Numa carta escrita ao Conde de Castiglione, Rafael afirma: "Como se vê tão poucas figuras femininas belas, então eu me apóio numa certa figura no espírito, que vem a minha alma". ${ }^{139}$ Essas palavras misteriosas do pintor são interpretadas de maneira religiosa pelo monge, que supostamente teria encontrado, entre os velhos manuscritos do mosteiro, uma carta de Bramante, que narraria uma visão que Rafael

\footnotetext{
${ }^{137}$ WACKENRODER, HKA I, p. 55.

${ }^{138}$ WACKENRODER, HKA I, p. 55-56.

${ }^{139}$ No original italiano: "Essendo carestia di belle donne, io mi servo di certa idea che me viene al mente". Para uma abordagem desse tópico em Rafael, cf. PANOFSKY, E. Idea: a evolução do conceito de belo. Trad. P. Neves. São Paulo: Martins Fontes, 2000, p. 5960.
} 
teve da própria Virgem Maria. Tal imagem teria ficado gravada firmemente em sua alma, o que explicaria a beleza insuperável das Madonnas pintadas por ele. O monge conclui que a inspiração do artista provém do imediato auxílio divino [göttlichen Beistand], e rechaça como "um verdadeiro pecado" o palavreado profano dos teóricos sistemáticos.

Deve-se lembrar que a carta de Rafael citada acima foi extraída das crônicas escritas por Vasari sobre as vidas dos pintores. Porém, a narrativa acerca da aparição da Virgem é ficcional, tendo sido acrescentada por Wackenroder. Tal recurso não foi visto com bons olhos por August Schlegel em sua recensão:

Não podemos aprovar inteiramente a mistura de verdade histórica e invenção [Erdichtung] no ensaio $A$ visão de Rafael. Ao escrever aquelas palavras, Rafael não se referia a uma Madonna, mas sim, à deusa do mar Galathea [...], a qual, como se sabe, não pertence aos mais elevados Ideais criados por seu pincel. ${ }^{140}$

Esse procedimento, que mistura ficção e realidade, é uma das principais características dos textos que constituem toda a primeira parte dos Herzensergießungen. Talvez isso possa ser justificado, em primeiro lugar, pelo desejo de se afastar do discurso racionalista usualmente utilizado pelos teóricos da época. Além disso, se é verdade que as palavras não conseguem alcançar os mistérios mais profundos da arte, e se todo sistema nada mais é que um falatório vazio, então será somente através dos exemplos concretos e dos testemunhos que o monge conseguirá demonstrar suas teses sobre a essência da arte e do fazer artístico.

O tema do gênio é explorado pelo narrador também nos textos seguintes. No ensaio sobre a morte do pintor Francesco Francia, por exemplo, o monge narra de que maneira esse pintor alcançou uma posição elevada na arte apenas por sua aplicação incansável

${ }^{140}$ In: WACKENRODER, HKA I, p. 421. 
[unermüdeten Fleiß]. ${ }^{141}$ No entanto, embora seus trabalhos possuam uma elevada qualidade técnica, falta-lhe o gênio. E é ao ver pela primeira vez, já em sua velhice, um quadro pintado por Rafael, que Francesco Francia se dá conta da imensa distância que os separa, e que a genialidade ali corporificada é um dom divino, que não pode ser alcançada pelo mero estudo da arte. Essa questão é aprofundada no ensaio seguinte, intitulado "Der Schüler und Raphael" [O aprendiz e Rafael]. Narrado sob forma epistolar, o jovem aprendiz se dirige a Rafael perguntando o que deve fazer para, em alguma medida, tornar-se semelhante a ele, pois diferentemente do que ocorre com as obras de outros mestres, o jovem relata a impossibilidade de se imitar as obras de Rafael e constata uma distância incomensurável entre sua cópia e o original.

Em resposta ao jovem aprendiz, Rafael limita-se a dizer que ele próprio não sabe explicar como executa suas obras:

[...] infelizmente eu não posso te dizer o que desejas saber de mim. Não porque seja um segredo que eu não queira revelar - pois eu gostaria de comunicá-lo, do fundo do coração, a ti e a todos - mas porque eu mesmo o desconheço. [...] Tu não irás acreditar em mim, e, contudo assim o é. Assim como ninguém pode explicar a razão pela qual possui uma voz rouca ou suave, tampouco eu poderia te dizer por que os quadros, em minhas mãos, tomam justamente essa forma e não uma outra. [...] Que eu tenha justamente essa maneira de pintar, e não outra [...] me parece fazer parte de minha natureza; eu não a obtive através do amargo suor, e não é algo que possa ser deliberadamente estudado. ${ }^{142}$

Embora não tenhamos nenhum subsídio documental ${ }^{143}$ que nos permita apontar uma influência direta de Kant, não podemos deixar de

\footnotetext{
${ }^{141}$ WACKENRODER, HKA I, p. 61.

${ }_{142}$ WACKENRODER, HKA I, p. 68-69.

${ }_{143}$ Deve-se lembrar, no entanto, a possibilidade de que Wackenroder e Tieck conhecessem a filosofia kantiana ao menos em segunda mão, por intermédio de Reichardt. Este publicara em sua revista, já no ano de 1791, diversos excertos da Crítica do Juízo - com especial ênfase aos parágrafos dedicados à teoria kantiana no gênio. A esse respeito, ver: REICHARDT, J. F. Musikalisches Kunstmagazin. 2. Bd.(7. Stück). Berlin: Im Verlage des Verfassers, 1791, p. 87-89.
} 
notar a semelhança entre a concepção exposta nesta carta fictícia de Rafael e alguns aspectos da concepção acerca do gênio exposta na Terceira Crítica. Ali, no $\S 46$, Kant definia a arte como um produto do gênio. E o gênio, por sua vez, era definido em primeiro lugar como sendo um talento inato, isto é, um dom natural e que não pode ser aprendido por meio de nenhuma regra. Assim, suas obras são marcadas pela originalidade e pela sua exemplaridade, ou seja, embora não tenham surgido por imitação, elas "têm de servir a outros como padrão de medida ou regra de julgamento". ${ }^{144}$ Segundo Kant:

O produto de um gênio (de acordo com o que nele é atribuível ao gênio e não ao possível aprendizado ou à escola) é um exemplo não para a imitação [...], mas para a sucessão por um outro gênio, que por este meio é despertado para o sentimento da sua própria originalidade. ${ }^{145}$

Embora a obra do gênio possa servir como modelo - não para a mera imitação - mas para despertar o outro gênio para sua própria originalidade, Kant afirma que o próprio gênio "não pode descrever ou indicar cientificamente como realiza seu produto":

[...] o próprio autor de um produto, que ele deve a seu gênio, não sabe como para isso as idéias se encontram nele e tampouco tem em seu poder [...] comunicá-las a outros em tais prescrições que os põem em condição de produzir produtos homogêneos. ${ }^{146}$

Mais adiante, Kant afirma que por mais minuciosos que possam ser os preceitos da arte poética, "não se pode aprender a poetar" [dichten lernen]:

Nenhum Homero ou Wieland pode indicar como as suas idéias imaginosas, e contudo ao mesmo tempo cheias de pensamento, surgem e se reúnem em sua cabeça, porque ele mesmo não o sabe e portanto também não pode ensinar a nenhum outro.

\footnotetext{
${ }^{144}$ KANT, KdU, § 46, B 182.

145 KANT, KdU, § 49, B 200.

${ }^{146}$ KANT, KdU, § 46, B 182.
} 
Analogamente ao que ocorre no caso da poesia, na narrativa de Wackenroder o pintor Rafael relata que, embora tenha aprendido até certo ponto por imitação, há algo inato em seu fazer artístico que não foi aprendido nem pode ser ensinado, que simplesmente escapa ao âmbito do estudo e do exercício. Também aqui podemos traçar um paralelo com relação a Kant quando ele afirma que a arte bela pressupõe também um lado mecânico, passível de ser captado e seguido segundo regras. Ele afirma inclusive que esse lado mecânico é uma "condição essencial da arte". ${ }^{147}$ Mas como vimos, embora o lado mecânico seja uma condição necessária, ele não é uma condição suficiente, pois o produto da bela arte depende também da originalidade do talento do artista genial.

Essa união entre genialidade artística e o estudo da arte é exemplificado pelo monge-narrador num outro ensaio, que trata da vida do pintor Leonardo Da Vinci. Através da biografia de Leonardo, ele mostra que a inspiração genial tem que estar unida a um estudo aplicado e profundo dos fundamentos da arte.

$O$ aspecto da originalidade do gênio é retomado pelo narrador no ensaio sobre Michelangelo. A essa originalidade se contrapõe o espírito de imitação. Porém, tudo aquilo que é grandioso, original e sublime na arte de Michelangelo torna-se, nas mãos de seus imitadores, apenas um pálido reflexo ou então um exagero caricatural:

Não há, no mundo dos artistas, absolutamente nenhum objeto mais elevado e mais digno de adoração do que: - um verdadeiro Original! [ursprünglich Original]. - Trabalhar com uma aplicação assídua, uma imitação fiel, um julgamento sensato, - é humano; mas penetrar a essência inteira da arte com um olhar inteiramente novo, apreendêla, por assim dizer, com um gesto totalmente novo, - é divino. Entretanto é o destino dos originais suscitar uma tropa miserável de imitadores [...]. Um original lança-se de uma vez com um salto audacioso até o limite do domínio da arte, e lá permanece, ousado e firme, e mostra o extraordinário e o maravilhoso [Wundervolle]. Mas

${ }^{147}$ KANT, KdU, § 47, B 186. 
para o espírito tolo do homem não há quase nada de extraordinário e maravilhoso cujo limite não seja muito próximo da insensatez [Torheit] e da falta de gosto [Abgeschmacktheit]. ${ }^{148}$

Além desses três mestres do Renascimento italiano, Wackenroder volta sua atenção também para o Renascimento alemão, representado pela figura do pintor Albrecht Dürer. Este ensaio - que chegou a ser publicado separadamente, antes da edição dos Herzensergießungen ${ }^{149}$ ocupa a posição central na estrutura geral do livro. Mas aqui, o tema central do ensaio não é tanto a questão do gênio, mas sim a relação entre arte e religião, que já havia sido esboçada anteriormente. ${ }^{150}$ Tal como ocorria com os ensaios a respeito dos pintores italianos, também aqui se evoca uma época de ouro da arte que contrasta enormemente com a época moderna. Se para Dürer e seus contemporâneos, a arte era algo elevado e sublime, na época do narrador a arte é considerada como um mero jogo [Spielwerk] agradável aos sentidos. Esse tema da decadência da arte é retomado por Wackenroder em outros ensaios - notadamente no ensaio sobre Joseph Berglinger - e reaparece na obra de outros autores posteriores, como Hoffmann, por exemplo.

\section{Crítica de arte e teoria da linguagem}

Uma das principais influências do teórico K. P. Moritz sobre a obra de Wackenroder pode ser encontrada em sua teoria da linguagem e,

\footnotetext{
${ }_{148}$ WACKENRODER, HKA I, p. 112.

${ }^{149} \mathrm{O}$ ensaio foi editado pela primeira vez na revista Deutschland (Bd. 3, 7. Stück, 1796, p. 59-73), editada pelo compositor J. F. Reichardt.

50 No ensaio "Uma carta do jovem pintor florentino Antonio a seu amigo Jacobo em Roma", lemos na resposta de Jacobo: "a arte [...] tem origem divina [himmlischen Ursprung]; ela deve ser cara ao artista, logo após a religião; ela tem que se tornar um amor religioso [religiöse Liebe] ou uma religião amada [geliebte Religion]". Cf. WACKENRODER, HKA I, p. 72.
} 
conseqüentemente, em sua crítica de arte. Como mencionamos anteriormente, Moritz defendia a tese de que não se pode descrever uma obra de arte através de palavras: as palavras acabam [aufhören] justamente "onde começa a verdadeira obra de arte". ${ }^{151}$ Há, portanto, uma espécie de incomensurabilidade entre a linguagem das palavras e a linguagem das formas, pois os conceitos são demasiadamente limitados para dar conta da multiplicidade de significados evocados pela obra de arte. Para Moritz, "a descrição através de palavras tem que se contentar em meramente indicar [anzudeuten] aquilo que a sua própria presença [Dasein] diz mais do que as palavras". ${ }^{152}$ No final de seu ensaio sobre a descrição das obras de arte, ele escreve:

Voltamos novamente ao ponto [inicial], de que as obras de artes plásticas já são em si a descrição mais perfeita [vollkommenste Beschreibung], e que não podem ser descritas novamente. Pois a descrição através dos contornos é já em si mesma mais significativa e determinada do que qualquer descrição através de palavras. ${ }^{153}$

As afirmações de Moritz acerca da escultura são reiteradas - mas agora referindo-se à pintura - pelo monge-narrador das Herzensergießungen:

Uma bela imagem ou quadro, a meu ver, absolutamente não podem ser descritos; pois no instante em que se diz mais do que uma única palavra a seu respeito, a imaginação foge do quadro e voa, por si só, pelos ares. ${ }^{154}$

Se, para Moritz, essa concepção acerca da impossibilidade da descrição de uma obra de arte através de palavras estava fortemente relacionada com sua concepção do belo como um todo consumado em si mesmo, em Wackenroder essa concepção se fundamenta, em primeiro

\footnotetext{
${ }^{151}$ MORITZ, K. P. Schriften zur Ästhetik und Poetik, p. 95.

${ }^{152}$ MORITZ, K. P. Schriften zur Ästhetik und Poetik, p. 94.

${ }^{153}$ MORITZ, K. P. Schriften zur Ästhetik und Poetik, p. 102.

${ }^{154}$ WACKENRODER, HKA I, p. 82.
} 
lugar, na primazia do sentimento. Em outras palavras: o belo não existe para ser descrito, mas para ser sentido. ${ }^{155}$ Para Moritz, a única possibilidade de uma obra de arte ser descrita através de palavras ocorre quando as próprias palavras se transformam em algo belo, "quando a verdade dá lugar à poesia [Dichtung] e a descrição e o descrito se tornam um só". ${ }^{156}$ Da mesma forma, para Wackenroder a única possibilidade de se descrever um quadro através de palavras é por meio do poema. Aliás, seu ensaio intitulado "Zwei Gemäldeschilderungen" [Duas descrições de quadros], das Herzensergießungen pode ser considerado como uma tentativa de aplicação desse princípio, na medida em que o narrador se afasta da tradição descritiva winkelmanniana, por exemplo, e procura descrever os dois quadros por meio de dois poemas. Esse procedimento foi elogiado por August Schlegel em sua recensão do livro:

A idéia de se descrever pinturas colocando em diálogo os seus personagens é original e pode, em muitos casos, ser bastante conveniente. Os dois exemplos [...] agradam por sua ingenuidade [Naivetät], mas [o autor] poderia ter tido maior esmero [Sorgfalt] com relação à forma $[\text { Form }]^{15}$

Tanto a teoria de Moritz como a sua aplicação por Wackenroder no interior das Herzensergießungen parecem ter, por sua vez, influenciado um aspecto central da teoria da poesia do Círculo de Jena, a saber, aquela concepção de que "poesia só pode ser criticada por poesia". No Fragmento 117 do Lyceum der schönen Künste (1797), podemos ler: "Um juízo artístico [Kunsturteil] que não é, ele próprio, uma obra de arte [...] não tem, em absoluto, direito de cidadania no reino da arte". ${ }^{158}$ Esse mesmo ponto de vista reaparece logo no início da Conversa sobre a poesia (1800), de Friedrich Schlegel:

\footnotetext{
${ }^{155}$ WACKENRODER, HKA I, p. 88.

${ }^{156}$ MORITZ, K. P. Schriften zur Ästhetik und Poetik, p. 99.

${ }^{157}$ In: WACKENRODER, HKA I, p. 422.

158 In: SCHLEGEL, F. Conversa sobre a poesia e outros fragmentos. Trad. V.-P. Stirnimann. São Paulo: lluminuras, 1994, p. 91.
} 
Não é preciso que alguém se empenhe em obter e reproduzir a poesia através de discursos e doutrinas racionais, ou mesmo produzi-la, inventá-la, estabelecê-la e fornecer-lhe leis punitivas, como seria do agrado da arte poética. Assim como o coração da terra se reveste de plantas e formas [...], assim também brota espontânea a poesia da força primeva e invisível da humanidade [...]. Somente as formas e cores podem expressar, em cópia [nachbildend], como o homem é constituído; e de poesia, também só se pode falar em poesia [und so läßt sich auch eigentlich nicht reden von der Poesie als nur in Poesie]. Todo ponto de vista a seu respeito será verdadeiro e bom, na medida em que for, também ele, poesia [Poesie]. ${ }^{159}$

Assim como Wackenroder ${ }^{160}$, também Schlegel nega a possibilidade de uma criação artística fundamentada em poéticas prescritivas. $E$ da mesma forma que a criação não se dá mediante a mera aplicação de regras, cai por terra a figura do crítico de arte enquanto "Kunstrichter" [Juiz de arte]. Pelo contrário, o que se exige do crítico é que ele próprio seja um artista, e que sua crítica seja também arte. E da mesma forma deve ser o papel do espectador. Como escreveu Tieck numa carta a Wackenroder (dezembro de 1792) "um poeta pressupõe um poeta como leitor". ${ }^{161}$

Em todos esses autores a arte pode ser considerada como tentativa de "dizer o indizível". ${ }^{162} \mathrm{Em}$ Wackenroder isso está ligado também a uma determinada concepção acerca da natureza da linguagem e da arte, expressa principalmente no ensaio "Von zwei wunderbaren Sprachen, und deren geheimnißvoller Kraft“" [De duas linguagens maravilhosas e de sua força misteriosa], nos Herzensergießungen. Ali, o narrador defende a tese da origem divina da linguagem das palavras [Sprache der Worte]. Tendoa recebido de seu Criador, através dela o homem pode nomear [nennen]

\footnotetext{
159 SCHLEGEL, F. Gespräch über die Poesie. Stuttgart: Metzler, 1968, p. 285. Trad. Bras. Conversa sobre a poesia e outros fragmentos. Trad. V.-P. Stirnimann. São Paulo: lluminuras, 1994, p. 30.

${ }_{160}^{16}$ WACKENRODER, HKA I, p. 87.

${ }^{161}$ WACKENRODER, HKA II, p. 113.

162 WACKENRODER, HKA I, p. 87.
} 
todas as coisas do mundo, e mesmo as imagens mentais que estão em seu interior: "através das palavras reinamos sobre a Terra inteira". ${ }^{163}$

Mas há um limite para a linguagem das palavras: "o invisível [das Unsichtabe], que paira acima de nós". A linguagem é um instrumento adequado apenas às coisas terrenas, mas que não consegue dar conta das coisas celestes. O narrador continua:

Eu conheço, porém, duas linguagens maravilhosas [wunderbare Sprachen], através das quais o Criador concedeu aos homens, tanto quanto é possível às criaturas mortais [...], apreender e compreender as coisas celestes em toda a sua potência. Elas penetram em nosso interior [Inneren] por caminhos completamente distintos que por meio do auxílio das palavras; elas movem [...] todo o nosso ser de uma maneira maravilhosa e penetram em cada nervo, em cada gota de sangue que nos pertence. Uma dessas linguagens maravilhosas é falada apenas por Deus; a outra é falada por apenas alguns poucos escolhidos [Auserwählte] dentre os homens, que ele consagrou como seus favoritos. Eu quero dizer: a Natureza e a Arte. ${ }^{164}$

Temos, portanto a linguagem falada apenas pelo Criador - "no princípio era Verbo" - que é a própria natureza. A outra linguagem, também criadora - trata-se da linguagem misteriosa da arte - é falada pelo gênio, que é um "escolhido" por Deus para ser uma espécie de intérprete das coisas divinas para os demais homens. Assim, o aspecto criador da arte também opera como elo de ligação entre arte e religião, na medida em que permite uma certa analogia entre a criação divina e a criação que é resultado da ação do gênio. Numa carta a Tieck datada de 11 de dezembro de 1792, Wackenroder afirma: "Somente criar [schaffen] nos aproxima da divindade [Gottheit], e o artista, o poeta, é criador [Schöpfer]. Viva a arte! Somente ela nos eleva acima da terra e nos torna dignos dos céus". ${ }^{165}$

\footnotetext{
${ }^{163}$ WACKENRODER, HKA I, p. 97.

${ }^{164}$ WACKENRODER, HKA I, p. 97.

${ }^{165}$ WACKENRODER, HKA II, p. 101.
} 
Diferentemente da linguagem das palavras, que consegue nomear e distinguir todas as coisas terrenas, a natureza e a arte se distinguem por serem linguagens misteriosas. Embora a "fala" dessas duas linguagens seja vedada ao homem comum, é somente por meio delas que ele tem acesso a uma verdade superior, que está muito além dos conceitos limitados de que dispõe a linguagem ordinária. Com efeito, apesar da natureza ser, por assim dizer, "o livro de explicações mais claro sobre a essência e as características [Eigenschaften] divinas"166, aquilo que ela revela não pode ser expresso em palavras, pois a linguagem das palavras é "um instrumento demasiado terreno e grosseiro para manejar as coisas incorpóreas [Unkörperliche] tal como se manejam as corpóreas". ${ }^{167}$ Dessa forma, diz o narrador, é em vão que os sábios tentam compreender os segredos divinos. Como é impossível explicar as coisas divinas através de meios meramente humanos, inevitavelmente eles acabam caindo em erro:

[...] eles quiseram descobrir os segredos do céu e colocá-los entre as coisas terrenas, sob uma luz terrena e [...] expulsaram do peito os seus sentimentos obscuros [dunkeln Gefühle]. - Consegue o homem em sua fraqueza iluminar os segredos celestes? Acredida ele, ousado, poder trazer à luz o que Deus cobriu com sua mão? Pode ele expulsar arrogantemente de si os sentimentos obscuros que descem sobre nós como anjos velados? - Eu os venero [os sentimentos obscuros] em profunda humildade; pois é uma grande graça de Deus que ele nos tenha enviado essas autênticas testemunhas da verdade. Eu junto as mãos e oro. ${ }^{168}$

Assim como a natureza revela ao homem um tipo de verdade superior, que não pode ser apreendida pela linguagem discursiva, mas apenas através de um sentimento obscuro, também a arte "através de

\footnotetext{
${ }^{166}$ WACKENRODER, HKA I, p. 97.

${ }^{167}$ WACKENRODER, HKA I, p. 98.

${ }^{168}$ WACKENRODER, HKA I, p. 98.
} 
caminhos similarmente obscuros e misteriosos" exerce "uma força maravilhosa sobre o coração dos homens". ${ }^{169}$ Prossegue o narrador:

[A arte] se serve, portanto, de uma escrita hieroglífica [Hieroglyphenschrift], cujos sinais [Zeichen] exteriores nós conhecemos e compreendemos. Mas ela funde o espiritual [Geistige] e o invisível [Unsinnliche] às formas [Gestalt] visíveis de uma maneira tão comovente e digna de admiração, que todo o nosso ser $[\ldots]$ é comovido e abalado. ${ }^{170}$

Já se pode antever as conseqüências dessa valorização da arte como uma linguagem obscura e misteriosa para a estética da música. Ao criticar a linguagem das palavras por banir tudo o que fosse obscuro e inacessível à razão, e ao valorizar o aspecto obscuro da arte - que embora seja inapreensível por meio da razão discursiva, possui um efeito muito mais profundo e direto sobre a alma das pessoas - Wackenroder abre também a possibilidade de valorização da arte dos sons. Não será por acaso que a reflexão sobre a música constituirá toda a segunda parte do livro, e que o artista moderno será exemplificado pela figura de um compositor. Pois a música, mais do que qualquer outra das belas-artes, rejeita o paradigma da imitação vigente até então, criando a partir de si mesma, sem apoiar-se em nenhum modelo exterior. Ao mesmo tempo, é a mais obscura das artes, e a única capaz de exprimir o indizível, ou seja, aquilo que a linguagem das palavras não é capaz de exprimir.

Comparada a essas duas linguagens misteriosas - a natureza e a arte - a limitação das palavras se mostra de maneira ainda mais contundente. Pois se ela só consegue dar conta das coisas terrenas e não consegue apreender as maravilhas celestes, tanto a natureza como a arte - embora por vias distintas - conseguem nos elevar de maneira imediata até a divindade, e são duas formas de apreensão do Absoluto: a

\footnotetext{
${ }^{169}$ WACKENRODER, HKA I, p. 98.

${ }^{170}$ WACKENRODER, HKA I, p. 98.
} 
natureza manifesta os mistérios divinos na exterioridade, e a arte volta-se para a interioridade. Como vimos, a criação do artista é, em certa medida, análoga à criação divina; e o gênio, através de suas criações, nos abre "os tesouros do peito humano, volta nosso olhar para nosso interior [Inneres] e nos mostra o invisível [das Unsichtbare], isto é, tudo o que é nobre, grande e divino, sob uma forma humana". ${ }^{171}$

Essa concepção da arte como algo divino irá determinar a teoria de Wackenroder não apenas no que concerne ao aspecto da criação artística, mas também no que diz respeito à recepção da arte por parte de quem a contempla. Com efeito, ao tratar das obras de arte do ponto de vista do espectador, Wackenroder irá defender a contemplação das obras de arte a partir de um sentimento de devoção religiosa. Esse ponto de vista é desenvolvido especialmente no ensaio "Wie und auf welcher Weise man die Werke der großen Künstler der Erde eigentlich betrachten, und zum Wohl seiner Seele gebrauchen müsse" [Como e de que maneira deve-se verdadeiramente contemplar as obras dos grandes artistas do mundo e utilizá-las para o bem de sua alma]. Um aspecto marcante aqui é a utilização que o narrador faz do vocabulário religioso (contemplação silenciosa e humilde, veneração, templo, prece) para caracterizar a postura ideal do espectador diante de uma obra de arte. Ao mesmo tempo, ele critica a concepção de arte como mero passatempo e como algo meramente agradável aos sentidos:

As galerias de pinturas são consideradas como feiras, onde as novas mercadorias são julgadas, louvadas e desprezadas de maneira superficial [im Vorübergehen]; e deveriam ser templos, onde, numa calma e silenciosa humildade [Demuth] e numa solidão que eleve o coração, admirar-se-iam os grandes artistas como aos mais elevados dentre os seres terrestres, e com a contemplação longa e fixa de suas obras, aquecer-se nos esplendor solar dos pensamentos e

\footnotetext{
${ }^{171}$ WACKENRODER, HKA I, p. 99.
} 
sentimentos mais encantadores. Eu comparo a fruição [Genuß] das mais nobres obras de arte à prece [Gebet]. ${ }^{172}$

Para o narrador, seria um sacrilégio [Frevel] entrar num museu, "a casa onde estão conservadas por toda a eternidade as criações mais dignas de admiração que puderam ser produzidas por mãos humanas, como uma mensagem silenciosa da dignidade dessa raça"173, sem estar imbuído de um sentimento de devoção religiosa. O espectador deve buscar unir sua alma com as obras dos artistas, formando um todo. Desse modo, é o coração e não a razão fria que possui a primazia quando se trata se contemplar uma obra de arte: "Suas figuras mágicas são mudas e fechadas quando as contemplais de maneira fria". ${ }^{174}$ As obras de arte não existem para serem analisadas e dissecadas através da razão do ávido construtor de sistemas. mas sim "para que se penetre nelas com 0 coração complacente e se viva e se respire em seu interior". ${ }^{175}$ Dada a inesgotabilidade de sentido de uma obra de arte, o deleite provocado por sua contemplação é também inesgotável. ${ }^{176} \mathrm{O}$ monge prossegue:

Acreditamos sempre penetrá-las mais profundamente e, não obstante, elas excitam os nossos sentidos de maneira sempre nova, e não vemos nenhum limite [Grenze] em que nossa alma pudesse esgotá-la [erschöpft]. Nelas flameja um óleo de vida que arde eternamente, o qual nunca se apaga diante de nossos olhos. ${ }^{177}$

\footnotetext{
${ }^{172}$ WACKENRODER, HKA I, p. 106.

173 WACKENRODER, HKA I, p. 107.

174 WACKENRODER, HKA I, p. 107.

175 WACKENRODER, HKA I, p. 107.

176 Pode-se encontrar este ponto de vista também em Moritz, como, por exemplo, na passagem seguinte: "A repetição [Wiederholung] do belo não suscita tédio [Überdruß], mas sim, um atrativo [Reiz] multiplicado". (Cf. MORITZ, K. P. Andreas Hartknopf Predigerjahre. Berlin: Unger, 1790, p. 26).

177 WACKENRODER, HKA I, p. 108.
} 
Diferentemente daquelas pessoas que procuram na arte somente a surpresa da novidade [Überraschung des Neuen], e que consideram que a sua principal finalidade é proporcionar prazeres aos sentidos, o narrador considera que a verdadeira forma de se contemplar uma obra de arte "exige uma serenidade silenciosa e tranqüila do ânimo [Gemüt], e se exterioriza não por meio de exclamações e palmas, mas somente através de movimentos interiores [innere Bewegungen]". ${ }^{178}$ Ele próprio somente se dirige à contemplação das obras de arte "com seriedade e com o ânimo [Gemüt] preparado", retornando incessantemente a elas, até que elas estejam firmemente impregnadas em seus sentidos e em sua imaginação [Einbildungskraft]. ${ }^{179}$ Por fim, a conclusão do ensaio é novamente dirigida contra os "juízes da arte": para o narrador, querer julgar um artista sublime é uma ousadia insensata e aponta para o orgulho vaidoso dos homens. Além disso, uma vez que a arte está acima dos homens, a atitude que se deve ter diante dela deve ser de humidade, admiração e veneração.

O ensaio que conclui a primeira parte das Herzensergießungen, intitulado "Die Mahlerchronik" [A crônica dos pintores], ao mesmo tempo em que sintetiza os principais temas abordados até este ponto, prepara também a transição da arte da pintura para a arte da música; da "época de ouro" dos grandes mestres renascentistas para a sua própria época. 0 enfoque da crítica de arte alcança então uma dimensão histórica, ou melhor, é pensado no campo de uma certa historicidade.

\footnotetext{
${ }_{178}^{178}$ WACKENRODER, HKA I, p. 108.

${ }^{179}$ WACKENRODER, HKA I, p. 108.
} 
Neste ensaio, o monge relata um episódio de sua juventude, quando conhece um religioso que the conta as vidas dos pintores e que, de certa forma, acabou por conduzi-lo ao estudo da história dos artistas, "que tanto alimento fornece ao entendimento [Verstand], ao coração e à fantasia". ${ }^{180}$ Ao narrar um episódio da vida de Domenichino, coloca-se em relevo a exigência de que o artista se coloque no mesmo afeto [Affekt] que ele deseja expressar na obra: "Quando pintava, ele penetrava em seu objeto sempre com a alma tão vivaz, que ele mesmo experimentava os sentimentos e afetos que ele queria representar". ${ }^{181}$ A tese acerca da impossibilidade de se descrever uma obra de arte mediante palavras é retomada com a narrativa sobre o pintor Annibale Caracci: "ele sentia intimamente a grandeza muda [die stumme Größe] da arte", e cuidava mais em produzir grandes obras do que jogar com palavras leves e graciosas sobre as grandes obras de arte. ${ }^{182} \mathrm{~A}$ tese segundo a qual uma obra de arte só pode ser descrita através de outra obra de arte também é retomada aqui, ao se narrar o episódio em que o irmão de Caracci tentava descrever minuciosamente com palavras todas as belezas particulares do Laocoonte, com discursos graciosos e, Annibale, ao invés de tentar descrevê-la através de palavras, desenhou, de memória, a escultura do Laocoonte "com tanta fidelidade e exatidão, que se acreditava tê-la sob os olhos". ${ }^{183}$

Com as narrativas de episódios da vida de Giotto, Jacques Callot e Albertinelli, já se antecipam temas que serão desenvolvidos na segunda

\footnotetext{
${ }^{180}$ WACKENRODER, HKA I, p. 129.

${ }^{181}$ WACKENRODER, HKA I, p. 124.

${ }^{182}$ WACKENRODER, HKA I, p. 125.

${ }^{183}$ WACKENRODER, HKA I, p. 125. Deve-se lembrar que a escultura de Laocoonte foi, na época, objeto de discussão de toda a estética alemã. Goethe, por exemplo, começa seu ensaio intitulado "Sobre Laocoonte" (1798) afirmando que uma obra de arte autêntica permanece sempre infinita para nosso entendimento, e que embora possa ser contemplada e suscite um certo efeito, ela não pode ser propriamente conhecida e sua essência não pode ser expressa por meio de palavras (Ver: GOETHE, J. W. Escritos sobre arte, p. 115).
} 
parte do livro, que trata da arte musical por meio da biografia de um compositor fictício chamado Joseph Berglinger. Tal como Berglinger, Giotto nasceu numa condição social desfavorável, mas parecia "chamado pelos céus para a arte da pintura". ${ }^{184}$ Jacques Callot antecipa o episódio da fuga de Berglinger, pois tal como este, não possui permissão do pai para estudar arte, e resolve fugir para realizar suas aspirações. Juntamente com Albertinelli, Berglinger irá partilhar a aversão ao estudo penoso da parte mecânica da arte. Por fim, com a vida de Fra Angélico, o narrador acentua a tese da ligação entre arte e religião, tese esta que permeia todo o livro.

Como já acentuamos anteriormente, toda a primeira parte dos Herzensergießungen dedica-se principalmente à arte da pintura, representada pelos mestres do Renascimento italiano e alemão, que constituiriam uma espécie de "época de ouro" da arte. Ao contrário das épocas posteriores, que pretenderam tornar-se grandes imitando a grandeza dos antigos mestres, o narrador se pergunta: "E esses ancestrais, quem eles imitavam? Eles tiravam todo o seu esplendor [Herrlichkeit] a partir de si mesmos [aus sich selber]". ${ }^{185}$

Ao voltar seu olhar para sua própria época, a pintura sai de cena e dá espaço à arte dos sons. Pode-se perguntar, então, por que Wackenroder teria escolhido justamente a música como representante da época moderna? Tendo em vista a teoria da arte esboçada ao logo da primeira parte do livro, podemos aventar algumas hipóteses. Em primeiro lugar, devido à proximidade entre música e religião. Essa proximidade já havia sido mencionada, muito de passagem, no ensaio sobre Albrecht Dürer, quando o narrador citava um escrito de Martinho Lutero, em que ele afirmava que "depois da Teologia, dentre todas as ciências e artes do

\footnotetext{
${ }^{184}$ WACKENRODER, HKA I, p. 125.

${ }^{185}$ WACKENRODER, HKA I, p. 112.
} 
espírito humano, é a música que ocupa o primeiro lugar". ${ }^{186}$ Além disso, a música é a arte da interioridade por excelência. Diferentemente das artes plásticas - pintura ou escultura - que expõem seus objetos visualmente no espaço; as obras musicais desdobram-se sucessivamente no tempo. A música é, portanto, uma arte progressiva e sentimental, no sentido schilleriano do termo. ${ }^{187}$ Com efeito, se os antigos (ingênuos) se caracterizavam pela arte da limitação [Begrenzung], os modernos (sentimentais) se caracterizam pela arte do infinito [Kunst des Unendlichen]:

A grande vantagem que as artes plásticas da Antigüidade afirmam sobre os tempos modernos e, acima de tudo, a relação desigual de valor em que estão a poesia e as artes plásticas modernas em face desses dois gêneros na Antigüidade explicam-se justamente pela força do artista antigo residir na limitação (e o que foi dito aqui do poeta pode, sob as restrições que se impõem por si, ser estendido ao artista em geral). Uma obra para o olho só encontra sua perfeição [Vollkommenheit] na limitação; uma obra para a imaginação [Einbildungskraft] pode alcançá-la também pelo ilimitado [Unbegrenzt]. [...] Em obras modernas isso é diferente, e se aqui os poetas antigos também vencem [...] naquilo que se pode expor sensivelmente e é corpóreo [körperlich], o moderno, por sua vez, pode deixá-los para trás na riqueza da matéria, naquilo que não pode se expor [undarstellbar] e é inefável [unaussprechlich], em suma, naquilo que nas obras de arte se chama espírito [Geist]. ${ }^{18}$

A partir dessas afirmações de Schiller resulta evidente que aquilo que ele afirma acerca da poesia vale também para a música. Pois não é a música justamente a arte que deixa para trás tudo o que é corpóreo e consegue expor o inefável? Com efeito, a afinidade especial entre a música e o gênero sentimental é posta em relevo pelo próprio Schiller ao

\footnotetext{
${ }^{186}$ WACKENRODER, HKA I, p. 92.

187 As reflexões de Schiller sobre a poesia ingênua e sentimental [naive und sentimentalische Dichtung] foram publicados pela primeira vez na revista Die Horen entre 1795-96 e é bastante provável que Wackenroder e Tieck tenham tomado conhecimento das mesmas.

${ }^{188}$ SCHILLER, F. Über naive und sentimentalische Dichtung. Stuttgart: Reclam, 2002, p. 37-38. Trad. Bras. Poesia ingênua e sentimental. Trad. M. Suzuki. São Paulo: lluminuras, 1991, p. 63.
} 
tratar de Klopstock, a quem denomina um "poeta musical" [musikalischen Dichter] e esclarece:

Digo musical para lembrar aqui a dupla afinidade da poesia, com a arte dos sons [Tonkunst] e com as artes plásticas [bildenden Kunst]. Ou seja, conforme imite um objeto determinado [bestimmten Gegenstand], como o fazem as artes plásticas, ou conforme produza apenas um estado da mente [Zustand des Gemüts], como a arte do som, sem ter para isso necessidade de um objeto determinado, a poesia pode ser chamada de plasmadora (plástica) ou de musical. ${ }^{189}$

Uma vez que a música reúne em si todas as características da arte tão admiradas pelo narrador das Herzensergießungen - a proximidade com a religião e o sentimento, a impossibilidade de ser descrita adequadamente através das palavras, a originalidade de uma arte que não é imitativa, mas que cria a partir de si mesma - e se, por ser a arte da interioridade e devido à sua capacidade de expor o inefável, é correto considerar a música como uma arte sentimental - e talvez a arte sentimental por excelência - poderemos perceber que não é por acaso que o artista moderno na segunda parte do livro será representado não mais por um pintor, mas sim, por um "artista dos sons" [Tonkünstler], isto é, por um compositor.

Klopstock - o "poeta musical", como o denominou Schiller - foi também bastante admirado por Wackenroder e Tieck, que chegaram, inclusive, a visitá-lo na cidade de Hamburgo em $1794 .{ }^{190}$ A concepção acerca da arte e do gênio expressa nas Herzensergießungen permite que se tracem alguns paralelos com os escritos de Klosptock, especialmente no que concerne à valorização da inspiração e do entusiasmo do gênio

\footnotetext{
${ }^{189}$ SCHILLER, F. Über naive und sentimentalische Dichtung, p. 55. Trad. Bras. Poesia ingênua e sentimental, p. 75.

${ }^{190}$ Cf. WACKENRODER, HKA II, p. 655.
} 
bem como do aspecto religioso e da expressão dos sentimentos através da obra de arte, em oposição à exatidão e clareza exigidas pelos teóricos racionalistas. No ensaio "Von der heiligen Poesie" [Da poesia sagrada], por exemplo, Klopstock opõe o gênio ao engenho [Witz] enquanto faculdade meramente combinatória: ${ }^{191}$

A poesia mais elevada é obra do gênio. [...] Há obras do engenho [Witz] que são magistrais, sem que o coração tenha contribuído com algo. Contudo, o gênio sem coração seria apenas um gênio pela metade. - Os efeitos últimos e mais elevados das obras do gênio estão no fato de moverem a alma inteira [die ganze Seele]. [...] Comover o coração inteiramente é o que há de mais elevado [das Höchste] em todo tipo de eloqüência [...]. Fazer isso através da Religião é ainda mais elevado. ${ }^{192}$

Conforme lembra Jochen Schmidt, temos novamente aqui a defesa do estilo de escrita que comove o coração [hertzrührende Schreibart], que fora preconizado por Bodmer e Breitinger, assim como a concepção segundo a qual o poeta não deve escrever a partir do "cálculo frio da razão", mas sim, a partir da paixão interior. Numa carta a Wackenroder datada de dezembro de 1792, Ludwig Tieck defende uma opinião semelhante:

Tome cuidado para não cometer o mesmo erro de tantos poetas: de pensar [denken] ao invés de sentir [Empfinden]. O poeta deve falar a partir de seu coração [aus seinem Herzen], e só assim ele irá nos comover [rühren]. Se ele for da observação [Beobachtung] para o sentimento [Empfindung], ele irá, na maior parte das vezes, tomar um caminho errado. Pode-se muito bem admirar ainda o plano bem ordenado, a bela métrica das sílabas, mas ele vai passar ao largo por nosso coração, e só vai agradar aos eruditos, que poderão citar uma grande quantidade de paralelos com Catulo, Horácio e Virgílio. ${ }^{193}$

Tanto para Tieck como para Klopstock, gênio e sentimento parecem ser indissociáveis, e a criação genial "só consegue comover o coração

${ }^{191}$ SCHMIDT, J. Die Geschichte des Genie-Gedankens I, p. 65.

192 KLOPSTOCK, F. G. "Von der heiligen Poesie". In: Ausgewählte Werke. Hg. Von Karl August Schleiden. München: Carl Hanser, 1962, p. 1000 e 1009.

${ }^{193}$ WACKENRODER, HKA II, p. 112. 
porque ela mesma tem sua origem no coração". ${ }^{194}$ Além disso, ao retomar a figura do poeta como visionário - isto é, divinamente inspirado, e não um mero erudito - Klopstock o faz dentro de uma conotação cristã. ${ }^{195}$

Wackenroder e Tieck extrapolam para o artista em geral essa dimensão religiosa que Klopstock conferia ao poeta genial, bem como sua capacidade de apreensão e apresentação do divino. É especialmente nos textos que tratam da vida do compositor Joseph Berglinger que essa influência de Klopstock se faz sentir de maneira ainda mais intensa.

Como mencionamos anteriormente, a partir do ensaio "Das merkwürdige musikalische Leben des Tonkünstlers Joseph Berglinger" [A vida musical do compositor Joseph Berglinger] há uma quebra na estrutura do livro, e o narrador abandona a perspectiva do historiador da arte passando a narrar a vida do amigo falecido a partir da lembrança dos seus relatos. Assim, a autenticidade dos relatos é garantida devido à proximidade entre os dois amigos, e também pelo fato do próprio Berglinger ter the contado a história de sua vida inúmeras vezes. Além disso, o monge acrescenta à narrativa fragmentos de escritos de Berglinger que ele teria encontrado entre seus pertences após sua morte prematura. A história de Berglinger é dividida pelo narrador em duas partes principais: na primeira, é narrada a infância de Berglinger, suas relações familiares e sociais, seu conflito interior e sua vocação para a música, culminando com sua fuga para a Residência Episcopal, a fim de se dedicar inteiramente à música. A segunda parte trata da inadequação do artista às exigências da sociedade da corte, do retorno à casa paterna e, por fim, da composição de sua última obra e da morte prematura de Berglinger.

\footnotetext{
${ }^{194}$ SCHMIDT, J. Die Geschichte des Genie-Gedankens I, p. 65. ${ }^{195}$ SCHMIDT, J. Die Geschichte des Genie-Gedankens I, p. 63.
} 
Nascido numa pequena cidade no sul da Alemanha, Berglinger foi criado apenas pelo pai, um médico já idoso, cujo maior desejo era que o filho se dedicasse também a essa profissão. ${ }^{196}$ Desde muito cedo fica clara a inadequação de Berglinger à sua família - inadequação esta que, mais tarde, irá se estender à sociedade como um todo. $O$ único consolo do jovem Berglinger será encontrado na arte da música e no impulso irresistível de tornar-se compositor e dedicar sua vida inteiramente à arte. $\mathrm{Na}$ medida em que não se trata da "escolha" por uma profissão como outra qualquer, mas de uma verdadeira "vocação" para a arte, no sentido religioso do termo, podemos notar a retomada do tema do gênio inato, mas agora no âmbito da arte musical. Desde o início da narrativa, o tema da interioridade do personagem se faz presente, o que, de certa forma, já prefigura a tendência de Berglinger em relação à música. Segundo o comentário de Elmar Hertrich, a música significa, para Berglinger, a sua vida interior amplificada. ${ }^{197}$

O narrador acentua também a força da imaginação de Berglinger, que desde pequeno vivia voltado para o seu fantasiar interior e cuja "principal alegria, desde os seus primeiros anos, era a música". ${ }^{198}$ Uma experiência decisiva deu-se durante uma viagem à casa de um parente numa cidade vizinha, que era também a Residência Episcopal. Nessa cidade, o pequeno Berglinger teve contato com a música sacra executada nas igrejas. Pela primeira vez ele tinha a oportunidade de ouvir "os Oratórios sacros, cantilenas e coros com tímpanos e trompetes". ${ }^{199}$ Sua

\footnotetext{
196 Muitos comentadores identificaram na história de Berglinger fortes traços autobiográficos de Wackenroder. No entanto, não iremos nos deter neste aspecto, uma vez que os possíveis paralelos entre as vidas de Wackenroder e do personagem Joseph Berglinger nos parecem ser de pouca relevância para a compreensão do livro.

${ }_{197}$ HERTRICH, E. Joseph Berglinger: eine Studie zu Wackenroders Musiker-Dichtung. Berlin: Walter de Gruyter, 1969, p. 29.

${ }_{198}$ WACKENRODER, HKA I, p. 131.

${ }^{199}$ WACKENRODER, HKA I, p. 132.
} 
atitude diante dessa música era de devoção interior ${ }^{200}$ [innerer Andacht] e, ao ouvi-la "ele se ajoelhava humildemente". ${ }^{201}$ Através da música Berlinger conseguia se afastar do mundo prosaico e "seu interior [Inneres] era purificado [...] de todas as mesquinharias terrenas". ${ }^{202}$ Quando a música finalmente chegava ao fim e ele voltava da igreja, era como se a música tivesse purificado e enobrecido a sua alma. Mas não apenas a música de igreja tinha esse efeito arrebatador sobre sua alma. Também a música de concerto era ouvida por ele com a mesma devoção que a música sacra:

Quando Joseph estava em um grande concerto, ele se sentava num cantinho, sem nem olhar para o magnífico grupo de ouvintes, e ouvia com a mesma devoção [Andacht], como se ele estivesse na igreja [als er in die Kirche wäre], - igualmente quieto e imóvel, com os olhos fixos no chão. ${ }^{203}$

A atitude ideal do espectador diante da obra de arte musical é descrita aqui através do exemplo do jovem Berglinger. Aqui fica claro que a atitude de devoção [Andacht] e recolhimento do ouvinte diante da música é fundamental, não importando se se trata de música religiosa ou de música de concerto. A atitude de respeito quase religioso do ouvinte perante a obra de arte musical deve ser a mesma. Além disso, o narrador enfatiza o completo desprezo de Berglinger pela música enquanto

\footnotetext{
${ }^{200} \mathrm{Em}$ seu artigo sobre Wackenroder e Moritz, H. J. Schrimpf observa que esse conceito de devoção à arte [Andacht zur Kunst], que é central nas Herzensergießungen, já estava presente num romance inacabado de Moritz, editado em 1794, intitulado "Die neue Cecilia". Ali, Moritz salienta que "o sentido para o belo da natureza e da arte é, originariamente, um sentido religioso, e é com 'devoção religiosa' que Cecília adentra o 'santuário da arte'". Mas Schrimpf nota ainda uma importante mudança de ênfase de Moritz para Wackenroder: para este, "a religiosidade está fundada no ânimo [Gemüt] do artista, e não mais, como em Moritz [...] na beleza corpórea das figuras. A alegria dos sentidos pagã-antiga é substituída pela interioridade cristã". Cf. SCHRIMPF, H.-J. "W.H. Wackenroder und K. Ph. Moritz: Ein Beitrag zur frühromantischen Selbstkritik". In: Zeitschrift für deutsche Philologie. Bd.84 (1964). S. 403-404.

${ }^{201}$ WACKENRODER, HKA I, p. 132.

${ }^{202}$ WACKENRODER, HKA I, p. 132.

${ }^{203}$ WACKENRODER, HKA I, p. 133.
} 
acontecimento meramente social. ${ }^{204}$ Se Kant ainda admitia a chamada "música de mesa" [Tafelmusik], que não é feita para se ouvir com atenção, mas para "preencher" o vazio e favorecer os convidados a uma alegre conversação ${ }^{205}$ entre si, Berglinger exige do ouvinte, diante de todo gênero musical, uma audição concentrada e atenta - muito semelhante àquela fruição verdadeiramente estética que, décadas mais tarde, seria definida por Hanslick como o escutar atento da sucessão de formas sonoras. Aliás, deve-se notar que apesar da defesa da música como expressão dos sentimentos, a atitude de Berglinger diante da obra de arte musical revela surpreendentes pontos de contato com a concepção estética de Eduard Hanslick. ${ }^{206} \mathrm{~A}$ atitude de Berglinger é a de um ouvinte completamente concentrado e ativo. Como o narrador salienta: "Nem o mínimo som the escapava, e por causa dessa atenção [Aufmerksamkeit] tão intensa, ele ficava, ao final, totalmente cansado [ermüdet] e sem forças". ${ }^{207}$ Essa característica peculiar da fruição de uma obra musical é mencionada também em duas cartas do próprio Wackenroder. Numa delas, datada de 27.11.1792, e endereçada a Tieck, ele afirma:

Ontem, como de costume, estive com Bernhardi no concerto das quartas-feiras. Como eu estou habitualmente muito atento [ao

\footnotetext{
${ }^{204}$ Neste aspecto, a atitude de Berglinger já antecipa a do Kapellmeister Kreisler. Embora o personagem criado por Hoffmann não seja tão impregnado desse sentido de religiosidade característico de Berglinger, pode-se afirmar que ambos atribuem o mesmo valor elevado à arte musical

${ }^{205}$ Essa passagem encontra-se no $\S 44$ da Crítica do Juízo de Kant: "Artes agradáveis são aquelas que têm em vista simplesmente o gozo. [...] A isto pertence também [...] a música de mesa: uma coisa singular, que deve entreter, somente como um rumor agradável, a disposição dos ânimos à alegria e, sem que alguém conceda à sua composição a mínima atenção, favorece a livre conversação entre um vizinho e outro" (Cf. KANT, KdU, § 44, B 178).

${ }^{206}$ Hanslick afirma que as obras musicais exigem do ouvinte "um acompanhamento incansável, na mais intensa atenção" (Cf. HANSLICK, E. Vom musikalisch-Schönen. Darmstadt: Wissenschaftliche Buchgesellschaft, 1973, p. 78-79. Trad. Port. Do Belo Musical. Trad. A. Morão. Lisboa: Ed. 70, 1994, p. 83).

${ }^{207}$ WACKENRODER, HKA I, p. 133.
} 
concerto], fica especialmente evidente para mim o quanto a música sempre me deixa cansado [müde]. ${ }^{208}$

No entanto, a referência mais significativa de Wackenroder a esse respeito está numa carta enviada a Tieck em 05.05.1792:

Quando vou a um concerto, penso que eu fruo a música sempre de duas maneiras. Somente uma maneira de fruição [Genuß] é a verdadeira [wahre]: ela consiste na mais atenta observação dos sons e seu avanço [aufmerksamsten Beobachtung der Töne und ihrer Fortschreitung]; na completa entrega da alma, nessa correnteza avassaladora de sentimentos; no distanciamento e afastamento de todo pensamento importuno e de toda impressão sensível que lhe seja estranha. Esse ávido sorver dos sons está ligado a um certo esforço [Anstrengung], que não se consegue agüentar por muito tempo. Justamente por causa disso é que eu acredito poder afirmar que só se consegue ouvir participativamente uma música durante uma hora, no máximo. Por isso, os concertos, óperas e operetas ultrapassam os limites da natureza. ${ }^{209}$

Além do aspecto da recepção da obra de arte musical por parte do ouvinte, também a valorização da música instrumental, e em especial das sinfonias $^{210}$, já é apontada no ensaio sobre Berglinger. Essa valorização está ligada à concepção da música como linguagem dos sentimentos ${ }^{211}$ que, como vimos, tem suas origens em Forkel e Moritz. Mas além disso, está ligada às qualidades de obscuridade e mistério, características da música instrumental. Diferentemente dos teóricos racionalistas, que consideravam tal obscuridade como um dos principais defeitos da música instrumental, para o narrador das Herzensergießungen, esse é "um dom maravilhoso da música", a qual "possui um efeito ainda mais poderoso sobre nós, e colocando em agitação todas as forças de nosso ser, quanto

\footnotetext{
${ }^{208}$ WACKENRODER, HKA II, p. 91.

${ }^{209}$ WACKENRODER, HKA II, p. 29.

${ }^{210}$ WACKENRODER, HKA I, p. 133.

${ }^{211}$ WACKENRODER, HKA I, p. 133-34.
} 
mais obscura e misteriosa [dunkler und geheimnisvoller] for a sua linguagem". 212

O retorno de Berglinger à casa paterna, seu conseqüente retorno ao mundo prosaico e o afastamento do mundo da música seria comparável, de certa forma, à expulsão do homem do Paraíso. Após experienciar esse mundo ideal proporcionado pela música, torna-se ainda mais doloroso para Berglinger retornar a um ambiente ao qual ele sente não pertencer, e no qual está impedido de realizar suas aspirações mais profundas. Seu conflito interior entre arte e vida comum vai, aos poucos, tomando proporções insustentáveis. A dificuldade de Berglinger em se adaptar às preocupações mesquinhas do cotidiano pode ser vista como um reflexo ou uma conseqüência - do sentimento de inadequação do artista perante o mundo prosaico. Aos poucos, sua vocação foi ficando mais evidente para ele: uma voz interior [innere Stimme] Ihe dizia incessantemente que ele havia nascido com uma finalidade mais elevada e nobre. Pouco a pouco, Berglinger se convenceu "de que tinha sido posto no mundo por Deus [...] a fim de que se tornasse um excelente artista na música". ${ }^{213}$ Nessa mesma época, Berglinger escreveu diversos poemas, os quais "ele musicou, sem conhecer as regras, em sua maneira pueril e repleta de sentimento". ${ }^{214}$ Após muito hesitar, Berglinger resolve abandonar a casa paterna e fugir para a cidade da Residência Episcopal, a fim de poder aprender a arte da música desde os seus fundamentos. Esse tema da fuga e da viagem é bastante comum na literatura romântica. A primeira frase do Werther, por exemplo, é significativa nesse sentido: "Sinto-me feliz por ter partido!". ${ }^{215}$ Elmar Hertrich nota que essa temática está

\footnotetext{
${ }^{212}$ WACKENRODER, HKA I, p. 134.

${ }^{213}$ WACKENRODER, HKA I, p. 136.

${ }^{214}$ WACKENRODER, HKA I, p. 136.

${ }^{215}$ GOETHE, J. W. Die Leiden des jungen Werther. München: DTV, 1978, p. 7. Trad. Bras. Os sofrimentos do jovem Werther. Trad. L. C. Lack. Sao Paulo: Nova Alexandria, 1999, p. 11.
} 
relacionada à tentativa de fuga do herói romântico "do mundo limitado da burguesia, que não tem lugar para eles", e que esse herói está "sempre em busca de um mundo mais elevado, em que possa encontrar a sua realização". 216

A segunda parte do ensaio começa muitos anos após a fuga de Berglinger da casa paterna. Ele se tornou Kapellmeister na Residência Episcopal e vive agora rodeado por um grande esplendor. Mas o esplendor do mundo exterior em que vive só serve para acentuar ainda mais sua miséria interior. É com amargura que ele constata que a realização dos seus sonhos de infância, de tornar-se um artista e dedicarse completamente à música, não o conduziu à felicidade desejada. Esse estado de ânimo é contado pelo próprio Berglinger, por meio de uma carta enviada ao narrador. Quanto à sua estrutura, podemos dividir a carta em quatro partes, nas quais ele aborda respectivamente sua relação com a música, com o público, com a sociedade de corte e com os demais músicos. A primeira parte da carta, que trata de sua relação com a música, gira em torno de sua recusa à "gramática da arte" $[\text { Kunstgrammatik] }]^{217}$, isto é, às suas regras mecânicas, em favor da expressão imediata dos sentimentos através de suas obras. A esse respeito, é possível traçar novamente um paralelo entre Berglinger e Werther. Na carta de 26 de maio de 1771, Werther escreve:

Isso fortaleceu minha resolução de, doravante, ater-me exclusivamente à natureza. Só ela é infinitamente rica; só ela forma [bildet] o grande artista. Pode-se dizer muitas coisas em favor das regras [Regeln], mais ou menos o que se pode dizer em favor da sociedade burguesa. Um homem que se forma de acordo com as

${ }^{216}$ HERTRICH, E. Joseph Berglinger: eine Studie zu Wackenroders Musiker-Dichtung. Berlin: Walter de Gruyter, 1969, p. 51.

${ }^{217}$ Segundo a definição de Forkel, a gramática musical [musikalische Grammatik] contém as regras [Vorschriften] para a conexão dos sons e acordes isolados [para a formação] das frases [Sätzen] e compreende os aspectos melódicos, harmônicos e rítmicos da música. Cf. FORKEL, J. N. Allgemeine Geschichte der Musik I. Leipzig: Schwickert, 1788 , p. $21,35-36$. 
regras jamais produzirá algo de mau-gosto [Abgeschmackt] ou ruim [Schlecht] [...]; mas em compensação [...] toda regra destrói o verdadeiro sentimento da natureza [wahre Gefühl von Natur] e a verdadeira expressão [Ausdruck] do mesmo. ${ }^{218}$

Tanto no caso de Werther ${ }^{219}$ como no de Berglinger, não é apenas a recusa às regras que está em jogo, mas também a adequação a uma sociedade vista por eles como artificial, em que o parecer se sobrepõe ao ser, ou seja, em que as aparências contam mais do que os sentimentos genuínos. Na segunda parte da carta, Berglinger narra sua relação com o público:

Como eu pude imaginar que esses ouvintes orgulhosamente vestidos em ouro e seda reunir-se-iam para fruir uma obra de arte, para aquecer seus corações, para oferecer seus sentimentos ao artista! Se mesmo na majestosa catedral, nas festividades mais sagradas, quando tudo que existe de mais belo e grandioso na arte e na religião penetra com força sobre eles, [os corações] desses ouvintes não são aquecidos, por que isso iria acontecer na sala de concertos? - O sentimento e o senso para a arte saíram de moda e se tornaram vulgares; demonstrar seus sentimentos [ao contemplar] uma obra de arte seria tão estranho e ridículo como querer falar [...] utilizando versos e rimas, enquanto todos utilizam a prosa racional e compreensível para se fazer entender. É para essas almas que eu trabalho! [...] Esse é o alto destino, para o qual eu acreditava ter nascido! $!^{220}$

Seu único consolo é imaginar que, mesmo muito tempo após a sua morte, alguém que possua uma tal simpatia [Sympathie] com sua alma, consiga sentir, através de suas melodias, exatamente o que ele sentiu ao

${ }^{218}$ GOETHE, J. W. Die Leiden des jungen Werther, p. 15. Trad. Bras. Os sofrimentos do jovem Werther, p. 19.

${ }^{219} \mathrm{Na}$ carta de 24.12.1771, Werther escreve: "E a miséria resplandecente [glänzende Elend], o tédio [Langeweile] que reina entre a gente estúpida que se vê por aqui! $\mathrm{E}$ a mania de posição social: espiam-se mutuamente apenas para encontrar uma oportunidade de passar a perna um no outro", Na carta de 08.01.1772, lemos ainda: "Que gente é essa, criaturas cujas almas são absorvidas pelas formalidades [Zeremoniell]; cujos interesses e esforços, durante anos inteiros, estao exclusivamente voltados em tentar conseguir a cadeira mais próxima da cabeceira da mesa de recepção! [...] Tolos, não vêem que o lugar nada significa, e que aquele que ocupa o primeiro posto nem sempre desempenha o papel mais importante!". GOETHE, J. W. Die Leiden des jungen Werther, p. 62-64. Trad. Bras. Os sofrimentos do jovem Werther, p. 72-73.

${ }^{220}$ WACKENRODER, HKA I, p. 140. 
escrevê-las. Esse conceito de simpatia, que possui um papel central neste trecho, aparece também nas cartas de Wackenroder e Tieck, e está intimamente ligado ao ideal de expressão dos sentimentos através da arte, típicos da Empfindsamkeit, e que já mencionamos anteriormente:

Tudo o que nos agrada nas belas-artes, só pode agradar na medida em que cada artista toca aqueles sons que ressoam de maneira clara e pura em nossa alma [...], é só dessa maneira que o poeta pode nos comover, pois a comoção [Rührung] nada mais é do que a simpatia [Sympathie] com a pessoa que nos comove [...]. No sublime [Erhabnen] nós descobrimos a nós mesmos, a simpatia nos atrai para a pessoa que pensa de maneira sublime, e esse amor mesclado com veneração pode ser tão forte, que ele irrompe em lágrimas. ${ }^{221}$

Mas na sociedade de corte em que vive, Berglinger perdeu completamente as esperanças de encontrar um ouvinte simpático aos seus sentimentos: é em vão que ele tenta comover seus ouvintes. $O$ fracasso de Berglinger como compositor não se deve ao seu suposto diletantismo, como acreditam alguns comentadores - pois um diletante dificilmente alcançaria a posição de Kapellmeister da corte. As causas de seu fracasso devem ser buscadas, antes, no descompasso entre a sensibilidade romântica de Berglinger enquanto compositor - que deseja expressar seus sentimentos e a sua subjetividade através de suas obras - e o público cortesão para quem ele escreve. O conflito de Berglinger reflete o surgimento da figura do músico criador autônomo em oposição ao músico empregado da corte. Na terceira parte de sua carta ao narrador, Berlinger descreve o conflito entre seu mundo interior e a sociedade de corte em que vive:

Porém, mais repugnantes são as outras relações em que o artista é enredado. Sobretudo [...] a subordinação da arte às vontades da corte. [...] É tudo tão indigno e tão humilhante para a alma humana,

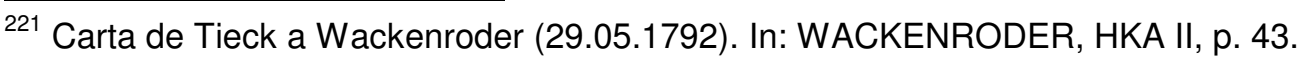


que minha língua não consegue pronunciar nem uma única sílaba a esse respeito. ${ }^{222}$

Essa subordinação da arte às vontades e aos caprichos da corte é algo insuportável para Berglinger. Pior ainda é a constatação de que os demais músicos da corte estão perfeitamente adaptados ao seu papel social, que consiste em entreter os ouvintes através da música. Esse conflito entre o artista genial e a sociedade, exposto através da figura de Berglinger, será também uma das principais marcas do personagem do Kapellmeister Kreisler, de E. T. A. Hoffmann - que irá retomar esse tema da inadequação do artista não mais no contexto da sociedade de corte, mas sim, no da sociedade burguesa. Da mesma forma, o tema da música como mero passatempo e prazer dos sentidos, que será abordado também por Hoffmann em alguns textos da Kreisleriana, já se faz presente nas Herzensergießungen:

Quão estranha e singular é a arte! Será que é só para mim que ela possui essa força tão misteriosa [geheimnisvolle Kraft], enquanto para as outras pessoas ela é apenas divertimento dos sentidos [Belustigung der Sinne] e um agradável passatempo [angenehmer Zeitvertreib]? O que ela é de fato, se para todas as pessoas a arte é um Nada, e somente para mim ela é Algo? Não é a mais infeliz das idéias fazer dessa arte a sua ocupação principal [...], dessa arte que na vida real terrena não desempenha nenhum papel diferente do que o jogo de cartas ou outro passatempo [Zeitvertreib] qualquer? $?^{223}$

Quando uma das composições de Berglinger finalmente parece ter obtido o efeito que ele sempre desejara, tocando o coração de seus ouvintes, ele recebe a notícia de que seu pai está muito doente e que suas irmãs estão vivendo em situação miserável. Ele retorna à sua cidade natal, mas seu pai falece logo em seguida. Mesmo profundamente abalado pela morte do pai, Joseph deve retornar à Residência Episcopal

\footnotetext{
222 WACKENRODER, HKA I, p. 141.

${ }^{223}$ WACKENRODER, HKA I, p. 142.
} 
para retomar suas atividades como compositor da corte. Como a Páscoa se aproxima, Berglinger deve compor uma nova música para ser usada na cerimônia da Sexta-feira da Paixão. Com lágrimas nos olhos, agitado por seus sentimentos e tomado por uma maravilhosa inspiração [Begeisterung], ele compôs uma Paixão que, "com suas melodias penetrantes, contendo todas as dores do sofrimento, permanecerá eternamente como uma obra-prima”. ${ }^{224}$ Mas os esforços empregados na composição e execução de sua música foram demais para Berglinger, que adoece e morre pouco tempo depois.

\section{Os escritos musicais de Berglinger}

As Phantasien über die Kunst (1799) foram editadas e publicadas por Tieck pouco após a morte de Wackenroder. No "Prefácio", Tieck escreve que Wackenroder tinha uma especial preferência pelos ensaios sobre música e ele sempre desejou vê-los editados. ${ }^{225}$ Por se tratar de uma espécie de continuação do livro anterior, a estrutura básica continua a mesma: um conjunto de ensaios divididos em duas partes principais, sendo a primeira delas dedicada à pintura ou à arte de maneira geral, e a segunda parte, dedicada apenas à música, reúne os escritos do personagem Joseph Berglinger. Embora a figura do monge-narrador reapareça aqui, cabe notar que seu papel é bastante reduzido, se comparado ao livro anterior; especialmente na segunda parte, na qual, ao invés de narrar diretamente os acontecimentos, o monge apenas assume o papel de editor ${ }^{226}$ dos ensaios e cartas que teriam sido escritos pelo

\footnotetext{
${ }^{224}$ WACKENRODER, HKA I, p. 144.

${ }^{225}$ WACKENRODER, HKA I, p. 149.

${ }^{226}$ Novamente é possível, a esse respeito, fazer um paralelo com o Werther, no qual também encontramos a figura do editor que apenas organiza as cartas do amigo falecido. O significado dessa estratégia e de outras que presidem o gênero do romance na segunda metade do século XVIII é amplamente investigado por Raquel de Almeida Prado e por Franklin de Matos. A esse respeito, ver: PRADO, R. A. Perversão da
} 
próprio Berglinger, principalmente durante seus anos de aprendizado na Residência Episcopal.

Nos textos da primeira parte, reencontramos alguns dos temas principais que já haviam aparecido nas Herzensergießungen, como o papel da inspiração na arte, a conexão íntima entre arte e religião e a "divindade da arte" [Göttlichkeit der Kunst], considerada como o produto mais sublime do espírito humano. A tese da impossibilidade da descrição de uma obra de arte através da linguagem das palavras - que, como vimos anteriormente, denota a influências das teorias de K. P. Moritz - é retomada no ensaio intitulado "Die Farben" [As Cores]. Ali, o narrador considera quase impossível a tarefa de se descrever uma pintura, pois "as palavras permanecem mortas e [...] não explicam nada”. É somente com uma descrição "genuinamente poética" que a linguagem das palavras consegue "suscitar um novo encanto" [Entzücken]. ${ }^{227}$

É nesse mesmo ensaio que a arte musical começa a assumir um papel de maior relevância perante as demais artes. Tal como ocorre com as artes figurativas, também a música não pode ser descrita por meio de palavras. Novamente aqui, podemos perceber a influência de Moritz, para o qual a música estava para além dos limites da linguagem e conseguiria expressar o inefável, ou seja, aquilo "que as palavras não conseguem expressar". ${ }^{228}$ Assim como Moritz, o monge-narrador considera a música como "um órgão mais fino que a linguagem":

A música é o último sopro dos espíritos [Geisterhauch], o elemento mais delicado, do qual os mais ocultos sonhos da alma tiram seu alimento, como de um riacho invisível; ela brinca em torno dos homem, quer tudo e nada, ela é um órgão mais fino [feiner] que a

retórica, retórica da perversão: moralidade e forma literária em 'As ligações perigosas' de Choderlos de Laclos. São Paulo: Ed. 34, 1997, p. 38ss. Cf. também: MATOS, F. O filósofo e o comediante: ensaios sobre literatura e filosofia na llustração. Belo Horizonte: Ed. UFMG, 2001, p. 223ss.

${ }^{227}$ WACKENRODER, HKA I, p. 192.

${ }^{228}$ MORITZ, K. P. Andreas Hartknopf. Eine Allegorie, p. 71. 
linguagem, talvez mais delicado [zart] que seus pensamentos, o espírito não pode mais usá-la como meio [Mittel], como órgão [Organ], mas ela é a coisa mesma [die Sache selbst], por isso ela vive e oscila em seus próprios círculos mágicos. ${ }^{229}$

O tema da autonomia da música - tratada como "a coisa mesma", e não como meio ou instrumento para um fim externo a ela - bem como a tese da música como uma linguagem menos grosseira que a linguagem das palavras (que são mencionados apenas de passagem nesse ensaio), serão desenvolvidos com maior pormenor na segunda parte do livro, que reúne, como já mencionamos, os ensaios sobre música escritos pelo compositor Joseph Berglinger.

No ensaio "Die Wunder der Tonkunst" [As Maravilhas da Arte Musical], Berglinger descreve a música como sendo a mais maravilhosa das belas-artes, pois somente ela "descreve sentimentos humanos de maneira sobre-humana e nos mostra todos os movimentos de nossa alma de forma incorpórea", utilizando uma língua "que não conhecemos na vida cotidiana, uma língua que aprendemos, não sabemos nem onde nem como, a única que gostaríamos de considerar como a linguagem dos anjos". ${ }^{230}$ É graças a essa linguagem obscura e intraduzível que a música obtém seus maiores efeitos. Ela não se dirige à razão, não deseja provar teses através de argumentos, mas penetra diretamente no coração e na alma de quem a ouve. De maneira mais poderosa do que as leis, a razão e a filosofia, a música fala diretamente ao coração ${ }^{231}$, através de uma força indescritível, que permanece inalcançável para a linguagem das palavras. Berglinger se pergunta:

Mas que palavras devo escolher e utilizar, para dar conhecimento da força que a música exerce sobre o nosso coração, com os seus sons opulentos, com as suas ressonâncias encantatórias? Ela entra

\footnotetext{
${ }^{229}$ WACKENRODER, HKA I, p. 191-92.

230 WACKENRODER, HKA I, p. 207.

${ }^{231}$ WACKENRODER, HKA I, p. 230.
} 
diretamente na alma, com a sua presença Angélica, e exala um hálito celestial. ${ }^{232}$

Como explicar essa ação irresistível que a música exerce sobre a alma de seus ouvintes? Embora Berglinger reconheça que os fundamentos da música repousam nas leis matemáticas da acústica, ele defende que não é graças a esse elemento racional que a música consegue suscitar efeitos maravilhosos no coração de seus ouvintes. Para ele, existe uma obscura e misteriosa simpatia "entre as proporções matemáticas do som e cada uma das fibras do coração humano". Graças a essa simpatia indescritível, a música transformou-se "num mecanismo rico e dócil, adequado à representação dos sentimentos humanos". ${ }^{233}$

Além dessa simpatia misteriosa entre o elemento material da música, isto é, o som, e os sentimentos humanos, Berglinger defende que há também um mecanismo de simpatia entre os sentimentos do artista e do ouvinte e que, em última instância, é válido não apenas para a música, mas para todas as artes de modo geral. De acordo com essa teoria, um sentimento só pode ser compreendido pelo sentimento, e "uma obra de arte só pode ser integralmente compreendida pelo mesmo sentimento que a produziu". ${ }^{234}$ Daí também a exigência de que o artista fale a partir de seu coração, pois somente se o próprio artista estiver comovido é que ele conseguirá comover seus ouvintes. Daí a crítica àqueles que apenas pensam ao invés de sentir" ${ }^{235}$ : "Quem quiser descobrir, com a varinha mágica da razão inquiridora, aquilo que só intimamente se pode sentir, descobrirá apenas pensamentos sobre o sentimento, mas nunca o próprio sentimento". ${ }^{236} \mathrm{E}$ ainda:

\footnotetext{
${ }^{232}$ WACKENRODER, HKA I, p. 229.

${ }^{233}$ WACKENRODER, HKA I, p. 217.

${ }^{234}$ WACKENRODER, HKA I, p. 219.

${ }^{235}$ Ver carta de Tieck a Wackenroder, de 20.12.1792 (WACKENRODER, HKA II, p. 112).

${ }^{236}$ WACKENRODER, HKA I, p. 218.
} 
Que pretendem os racionalistas timoratos e desconfiados, que exigem a explicação por palavras de cada uma das centenas e centenas de obras musicais e não conseguem entender que nem todas têm um significado específico, como acontece na pintura? Pretenderão eles aferir a linguagem mais rica pela mais pobre e reduzi-la a palavras? Será que eles encheram o coração vazio apenas com descrições de sentimentos? ?37 $^{237}$

É no ensaio intitulado "Symphonien" [Sinfonias] que todos esses aspectos encontram uma espécie de síntese, cujas conseqüências seriam de grande importância para a estética musical posterior. A música, que é tida por Berglinger como "a mais obscura [dunkleste] de todas as artes", é considerada aqui como "o mistério último da fé, a mística, a religião totalmente revelada". ${ }^{238}$ Essa valorização da obscuridade da música, como já vimos anteriormente, estava ligada à tese que considerava a música como uma linguagem dos sentimentos. Mas a tese mais radical, sem dúvida, é a que propõe a radical separação entre a música vocal e a música instrumental. Se tradicionalmente a música vocal era vista como superior, pois com o auxílio da poesia, ela conseguiria chegar a um grau de determinação que a música instrumental por si jamais conseguiria alcançar, a partir daqui teremos a inversão total desse ponto de vista: Berglinger defende que a música não deve ser considerada como um mero complemento da poesia, mas deve ser fruída por si só, em sua plena autonomia:

A música instrumental deveria, talvez, mover-se na sua própria força, respirar no seu elemento característico, sem qualquer acompanhamento instrumental; tal como a música instrumental segue o seu próprio caminho e não se interessa por nenhum texto, por nenhuma poesia subjacente, poetando para si própria e comentando-se a si mesma poeticamente. Ambas as formas [música

\footnotetext{
${ }^{237}$ WACKENRODER, HKA I, p. 219.

${ }^{238}$ WACKENRODER, HKA I, p. 241.
} 
vocal e música instrumental] podem existir independentemente puras e separadas. ${ }^{239}$

A defesa da música instrumental em sua autonomia só foi possível com a superação do princípio de imitação da natureza. No caso da arte dos sons, isso aparecia com clareza no ensaio "Die Töne" [Os sons], no qual Berglinger afirmava claramente que a música, já por meio de sua matéria-prima, não é uma arte imitativa [sie ahmt nicht nach], e que ela constitui um mundo isolado [abgesonderte Welt] por si mesma. ${ }^{240}$

Berglinger considera a música vocal como uma arte condicionada [bedingte]. Por estar ligada a um poema, ela é, em última instância, "apenas uma declamação, um discurso elevado", ao passo que somente a música instrumental é verdadeiramente independente e autônoma, pois "fixa para si as suas leis". Através do seu jogo livre e sem objetivo, ela "alcança o objetivo mais elevado", e com sua linguagem obscura, ela "exprime o que há de mais profundo e de mais maravilhoso". ${ }^{241}$

Dentre os diversos gêneros de música instrumental, a posição mais elevada vai ser ocupada pela sinfonia:

Os coros plenos, as peças a várias vozes complexamente elaboradas com toda a arte, constituem o triunfo da música vocal; mas o supremo triunfo, o mais belo louvor dos instrumentos são as sinfonias. As sonatas, os artísticos trios e quartetos são como que os exercícios escolares para esta perfeição da arte. O compositor tem aqui um campo infindável para mostrar sua força, a sua profundidade de pensamento; aqui, pode falar a elevada linguagem poética, que desvenda em nós o que há de mais maravilhoso e põe a descoberto todas as profundidades. ${ }^{242}$

Essa supremacia da sinfonia já tinha sido antecipada no ensaio anterior "A essência singular da arte musical e a psicologia da música instrumental contemporânea", em que a sinfonia era igualmente tratada

\footnotetext{
${ }^{239}$ WACKENRODER, HKA I, p. 242.

${ }^{240}$ WACKENRODER, HKA I, p. 236.

${ }^{241}$ WACKENRODER, HKA I, p. 243.

242 WACKENRODER, HKA I, p. 243-44.
} 
como o "último e supremo triunfo dos instrumentos", na qual se encontra representado "todo um drama dos afetos humanos". ${ }^{243}$ Essa analogia com o drama é retomada aqui. Mas cabe notar que se trata de um drama superior àquele produzido pelo poeta, pois enquanto este permanece ligado à linguagem limitada das palavras, e às leis de verossimilhança, a música permanece num mundo puramente poético. A linguagem misteriosa dos sons não necessita representar nada de exterior, de modo que matéria e objeto, forma e conteúdo encontram-se unidos, mais do que em qualquer outra forma de arte, de maneira indissolúvel:

\begin{abstract}
Estas sinfonias podem representar um drama tão variegado, tão complexo, confuso, com um tão belo desenvolvimento, como o poeta jamais pode nos dar; pois que revelam em linguagem enigmática o que há de mais enigmático, não dependem de quaisquer leis da verossimilhança, não precisam recorrer a quaisquer histórias ou caracteres e permanecem em seu mundo puramente poético. [...] A matéria instrínseca é, desde o princípio até o fim, o seu objeto; a própria finalidade está presente em cada momento e com ela começa e termina a obra de arte. ${ }^{244}$
\end{abstract}

Através da leitura dos ensaios sobre o compositor Joseph Berglinger, percebe-se a ligação desse personagem com as tradições estéticas da Empfindsamkeit e do Sturm und Drang, especialmente no que diz respeito à valorização da expressão subjetiva do artista através da obra de arte, bem como sua crítica às poéticas normativas, à criação e ao julgamento da obra de arte a partir de regras. Mas ao mesmo tempo em que muitos temas presentes nos textos musicais desse personagem possuem sua origem em movimentos estéticos anteriores, é preciso salientar também que esses textos contêm inúmeras idéias e problemas

\footnotetext{
${ }^{243}$ WACKENRODER, HKA I, p. 221.

${ }^{244}$ WACKENRODER, HKA I, p. 244.
} 
novos, que seriam retomados e retrabalhados por outros autores, como já mencionamos no incício deste capítulo, de modo que se poderia considerar o personagem Joseph Berglinger como uma espécie de "elo entre Empfindsamkeit e Romantismo". Na formulação de Elmar Hertrich, Berglinger "marca o ponto de virada no qual o subjetivismo tardio da Empfindsamkeit faz surgir a problemática da arte e do artista do Romantismo". ${ }^{245}$ De especial interesse para o desenvolvimento de uma estética musical romântica foram, em primeiro lugar, o reconhecimento da obscuridade da música como índice de uma riqueza de significados que ultrapassa o âmbito limitado da linguagem das palavras. Em segundo lugar, a música deixa de ser vista como um passatempo agradável, mera fonte de deleite, e passa a ser vista como forma de acesso ao divino, "o mistério último da fé", "a Religião totalmente revelada". 246 Essas formulações abrem caminho para a concepção romântica ${ }^{247}$, em que a música se torna não somente a mais elevada dentre as belas-artes, mas também o lugar privilegiado de experiência do Absoluto.

\footnotetext{
${ }^{245}$ HERTRICH, E. Joseph Berglinger: eine Studie zu Wackenroders Musiker-Dichtung. Berlin: Walter de Gruyter, 1969, p. 222.

${ }^{246}$ WACKENRODER, HKA I, p. 241.

${ }^{247}$ Waizbort observa, com razão, que "a religião da arte romântica foi uma emancipação da arte, que deixou de servir a qualquer função que lhe fosse exterior, deixou de ser música funcional. Isso se concretizou sobretudo na música instrumental; liberta de vínculo com a língua, apenas ela constitui-se como música plena e pura" (WAIZBORT, L. "Chaves para ouvir Schumann", p. 186).
} 


\title{
IV. KANT E SCHELLING: DA INTUIÇÃO INTELECTUAL À INTUIÇÃO ESTÉTICA
}

\begin{abstract}
"A arte [...] consegue para a intuição [Anschauung] justamente aquilo que a mais alta filosofia consegue através da especulação". ${ }^{48}$
\end{abstract}

No primeiro capítulo de sua "Introdução à Estética do Primeiro Romantismo", Manfred Frank chama a atenção do leitor para o fato de que, no interior de uma certa tradição filosófica ocidental, sempre houve uma considerável desconfiança com relação à Estética: "De Platão a Frege, sem esquecer Descartes, nada esteve sob maior suspeita do que a segurança [que podemos obter através] dos sentidos". ${ }^{249}$ Como nos mostra Frank, se é certo que a filosofia aspira à verdade, e se o verdadeiro é concebido como sendo aquilo que se mantém imutável e imune ao fluxo do devir; e ainda, se a aspiração maior das ciências e da filosofia sempre foi trabalhar com conceitos firmes e bem-definidos, então podemos compreender um dos motivos pelos quais a Estética justamente por lidar com a esfera do sensível - esteve sempre sob

\footnotetext{
${ }^{248}$ SCHLEGEL, A. W. Die Kunstlehre. Hg. E. Lohner. Stuttgart: W. Kohlhammer, 1963, p.

${ }^{729}$ FRANK, M. Einführung in die frühromantische Ästhetik. Frankfurt a.M.: Suhrkamp, 1989, p. 8.
} 
suspeita desde a Antiguidade Clássica. Por esse motivo, a arte foi considerada, ao longo de mais de dois mil anos, "como uma espécie de conhecimento menor e tateante ('cognitio inferior', na famosa definição de Alexander Baumgarten)". ${ }^{250}$ Ora, para que a estética pudesse adquirir importância para a reflexão filosófica era necessário que se operasse uma profunda modificação no antigo paradigma filosófico. Nas palavras de Frank, "foi preciso que a concepção acerca da essência da representação e o modelo de verdade [que estava] intimamente ligado a ela fossem fundamentados de maneira completamente nova". ${ }^{251}$ Foi somente a partir do momento em que ocorreu uma ruptura radical com um modelo de verdade que pressupunha uma correspondência simples entre a coisa e o intelecto, que a expressão estética pôde adquirir relevância para a filosofia. E essa ruptura deve-se principalmente à chamada "revolução copernicana" ocasionada pela filosofia crítica de Kant, e inaugurada no ano de 1781, com a publicação da Crítica da Razão Pura. No "Prefácio" à segunda edição da Primeira Crítica, Kant escreve:

Até hoje admitia-se que o nosso conhecimento se devia regular pelos objetos; porém, todas as tentativas para descobrir a priori, mediante conceitos, algo que ampliasse o nosso conhecimento, malogravamse com esse pressuposto. Tentemos, pois, uma vez, experimentar se não se resolverão melhor as tarefas da metafísica, admitindo que os objetos se deveriam regular pelo nosso conhecimento, o que assim já concorda melhor com o que desejamos, a saber, a possibilidade de um conhecimento a priori desses objetos, que estabeleça algo sobre eles antes de nos serem dados. [...] Se a intuição tivesse de se guiar pela natureza dos objetos, não vejo como deles se poderia conhecer algo a priori; se, pelo contrário, o objeto (enquanto objeto

${ }^{250}$ FRANK, M. Einführung in die frühromantische Ästhetik. Frankfurt a.M.: Suhrkamp, 1989, p. 14.

${ }^{251}$ FRANK, M. Einführung in die frühromantische Ästhetik. Frankfurt a.M.: Suhrkamp, 1989, p. 14. 
dos sentidos) se guiar pela natureza da nossa faculdade de intuição, posso perfeitamente representar essa possibilidade. ${ }^{252}$

Como bem notou Frank, o cerne dessa revolução operada por Kant está na demonstração de que "há uma relação entre a estrutura do objeto [Objekt] e a forma do juízo [Urteil]":

A idéia central de Kant [...] é que, aquilo que nós chamamos de objetos [Objekte] nada mais é do que aquilo a que nós nos referimos nos juízos verdadeiros. Nisso consiste a diferença entre os objetos [Objekte] e os objetos [Gegenstände] de representações meramente subjetivas (KrV B 142). Ora, pensar é julgar, e julgar é a função através da qual uma multiplicidade de representações distintas é unificada numa única representação. ${ }^{253}$

Kant coloca na atividade do sujeito a chave para o conhecimento dos objetos da experiência, de modo que o sujeito transcendental se torna condição de todo e qualquer conhecimento. Dessa maneira, Kant transformou completamente o fundamento epistemológico da metafísica, mostrando que o sujeito não é meramente passivo ou receptivo, mas antes, que "o pensamento se baseia numa atividade, cujo autor é o sujeito consciente-de-si [selbstbewußte Subjekt]. O intelecto [...] constitui uma imagem do mundo [...], não como ele é, mas como ele aparece [erscheint] para nós". 254

A filosofia de Kant estabeleceu definitivamente a impossibilidade de se ultrapassar os limites da experiência possível. Nosso conhecimento refere-se apenas a fenômenos e não às coisas em si que, "embora em si mesmas reais, se mantêm para nós incognoscíveis". ${ }^{255}$ Embora se possa pensá-lo, o supra-sensível não pode ser conhecido, de modo que o

252 KANT, I. Kritik der reinen Vernunft. Hamburg: Felix Meiner, 1998. Trad. Port.: Crítica da Razão Pura. Trad. M. Pinto dos Santos e A. F. Morujão. Lisboa: Calouste Gulbenkian, 2001. (Doravante: KrV) B XVI-XVII.

${ }^{253}$ FRANK, M. Einführung in die frühromantische Ästhetik. Frankfurt a.M.: Suhrkamp, 1989, p. 15.

${ }^{254}$ FRANK, M. Einführung in die frühromantische Ästhetik. Frankfurt a.M.: Suhrkamp, 1989, p. 14.

${ }^{255} \mathrm{KrV} \mathrm{B} X \mathrm{X}$. 
conhecimento objetivo é, pois, o conhecimento dos fenômenos, limitandose àquilo que é condicionado. ${ }^{256}$

Entretanto, como nota Pedro Pimenta, "em se tratando de conceito que encerra a série dos fenômenos sensíveis, o incondicionado é requerido para que o sistema do conhecimento se complete". ${ }^{257} \mathrm{~A}$ exigência do incondicionado ${ }^{258}$, indicada por Kant no $\S 76$ da Crítica do Juízo ${ }^{259}$ foi profundamente sentida pelos pensadores pós-kantianos, para os quais essa problemática do Absoluto se resolve, de certa forma, não propriamente no âmbito da filosofia, mas no âmbito da arte. Isso é especialmente claro no primeiro período da produção filosófica de Schelling.

$\mathrm{Na}$ sétima de suas Vorlesungen über schöne Literatur und Kunst [Preleções sobre bela litaratura e arte], ministradas em Berlim no ano de 1801, A. W. Schlegel afirma que, comparada às teorias idealistas, a teoria kantiana da arte, tal como exposta na Crítica do Juízo, se deteve no meio do caminho [auf halbem Wege stehengeblieben ist]. A seu ver, Schelling

\footnotetext{
${ }^{256}$ Além da "revolução copernicana", deve-se ressaltar o lugar que a imaginação ocupa na Crítica da Razão Pura e, posteriormente, na Crítica do Juízo, tornando-se ainda o centro da filosofia de Fichte (a esse respeito cf. TORRES FILHO, R. R. O Espírito e a Letra. São Paulo: Ática, 1975). Quer-nos parecer que esses elementos, bem como a noção de reflexão, estão na base do pensamento romântico quando ele se aproxima da música.

${ }^{257}$ PIMENTA, P. P. Reflexão e moral em Kant. Rio de Janeiro: Azougue, 2004, p. 30.

${ }^{258}$ A esse respeito, cf. ainda: TORRES FILHO, R. R. "Produção extrateórica da síntese". In: Ensaios de filosofia ilustrada. São Paulo: lluminuras, 2004, p. 164-5: "A questão que move esse ensaio (Vom Ich), subtitulado 'Sobre o incondicionado no saber humano', é, declaradamente, a de encontrar o fundamento, o alicerce, a base (Grund) onde possa assentar-se definitivamente o edifício da filosofia crítica - a filosofia dos novos tempos, que a crítica da razão inaugurada por Kant teve o mérito de inaugurar e augurar. Esse fundamento, que Schelling propõe seja tomado como princípio, está ausente em Kant, que nunca o formulou, apenas o pressupôs, e só pode ser o próprio incondicionado que nesse texto aparece sob o título de 'eu absoluto' (...) isto é, não relativo a nenhum não-eu oposto a ele, com o qual estivesse numa relação de determinação recíproca".

${ }^{259}$ KANT, I. KdU, § 76, B 339: "A razão é uma faculdade dos princípios e caminha para o incondicionado em sua exigência mais extrema". E mais adiante (B 341) ele fala de uma: "[...] incessante exigência da razão em aceitar algo (o fundamento originário) como existindo necessariamente incondicionado".
} 
foi o primeiro filósofo que conseguiu ir além de Kant nesse campo ${ }^{260} \mathrm{e}$ quem primeiramente começou a colocar expressamente "as bases de uma doutrina da arte filosófica em ligação com o princípio do idealismo transcendental", tendo dedicado à arte uma seção inteira em seu sistema. $^{261}$

É ao "Sistema do Idealismo Transcendental", publicado por Schelling em 1800, que August Schlegel faz referência aqui. A relevância dessa obra - em cujo último capítulo se percebe a influência de autores como Novalis, Tieck, e dos próprios irmãos Schlege ${ }^{262}$ - não pode ser subestimada: nela a arte alcança uma importância filosófica tal como nunca antes fora possível na história do pensamento. Ainda nas palavras de A. W. Schlegel, nessa obra Schelling teria colocado a arte "em seu verdadeiro ápice [Gipfel], enquanto dissolução [Auflösung] de uma contradição infinita [eines unendlichen Widerspruchs] no homem, [enquanto] a reunificação das aspirações [Strebungen] divididas do espírito humano em última instância". ${ }^{263}$ A união entre necessidade e liberdade, a passagem entre filosofia teórica e prática, tão almejada por Kant, será levada a cabo, no "Sistema do Idealismo Transcendental", por meio da arte e do belo - considerado por ele como sendo o infinito exposto finitamente [das Unendliche endlich dargestellt]. Daí a tese, defendida por Schelling, de que a arte é o único e verdadeiro órganon e, ao mesmo tempo, o documento da filosofia.

Assim, cabe agora investigar as seguintes questões: como foi possível que a arte adquirisse essa importância para a filosofia? De que

\footnotetext{
${ }^{260}$ Ele afirma que Fichte se exprimiu "apenas de passagem" sobre a estética em sua doutrina dos costumes. Cf. SCHLEGEL, A. W. Die Kunstlehre. Hg. E. Lohner. Stuttgart: W. Kohlhammer, 1963, p. 80.

${ }^{261}$ SCHLEGEL, A. W. Die Kunstlehre. Hg. E. Lohner. Stuttgart: W. Kohlhammer, 1963, p. 80.

${ }^{262}$ Cf. TILLIETTE, X. L'absolu et la philosophie: essais sur Schelling. Paris: PUF, 1987, p. $92-95$.

${ }^{263}$ SCHLEGEL, A. W. Die Kunstlehre, p. 80-81.
} 
maneira a arte apresenta uma possibilidade de exposição do infinito ou do absoluto?

Essas questões constituíam o horizonte comum das reflexões de Schelling, bem como de alguns de seus colegas do Stift de Tübingen. Uma proposta de solução foi esboçada já no fragmento conhecido como O mais antigo programa de sistema do Idealismo alemão ${ }^{264}$ :

Por último, a Idéia que unifica tudo, a Idéia da beleza [Schönheit], tomada a palavra em seu sentido superior, platônico. Pois estou convicto de que o ato supremo da Razão, aquele em que ela engloba todas as Idéias, é um ato estético [ästhetischer Akt], e que verdade e bondade [Wahrheit und Güte] só estão irmanadas na beleza. O filósofo tem de possuir tanta força estética quanto o poeta. Os homens sem senso estético [ästhetischen Sinn] são nossos filósofos da letra. A filosofia do espírito é uma filosofia estética [...] A poesia [Poesie] adquire com isso uma dignidade superior, torna-se outra vez no fim o que era no começo - mestra da humanidade; pois não há mais filosofia, não há mais história, a arte poética [Dichtkunst] sobreviverá a todas as outras ciências e artes. ${ }^{265}$

Partindo do estudo da Terceira Crítca de Kant, bem como dos escritos filosóficos de Platão, Hölderlin ${ }^{266}$ procurava indicar que a

\footnotetext{
${ }^{264}$ Publicado pela primeira vez somente em 1917, por Franz Rosenzweig, o fragmento data de 1796/97, aproximadamente. Embora a caligrafia seja de Hegel, a autoria do texto é incerta: alguns estudiosos consideram Schelling como sendo o autor; outros a consideram como sendo da autoria de Hegel, por fim, outros consideram que o texto teria sido escrito por Hölderlin.

265 "Das sogenannte Älteste Systemprogramm". In: FRANK, M.; KURZ, G. (Hg). Materialien zu Schellings philosophischen Anfängen. Frankfurt a.M.: Suhrkamp, 1975, p. 111 (trad. Brasileira de R. Rodrigues Torres Filho. In: SCHELLING, F.W.J. Obras escolhidas. São Paulo: Abril Cultural, 1984, p. 42-43).

${ }^{266}$ Cf. HÖLDERLIN, F. Sämtliche Werke. Bd. 6 (Briefe). Hg. A. Beck. Stuttgart: Kohlhammer, 1965, em especial: carta a seu irmão, de 21.05.1794: "Kant é praticamente minha única leitura no momento. Esse espírito esplêndido se revela cada vez mais para mim" (Op. Cit, p. 130); carta a Hegel, de 10.07.1794: "Minha ocupação agora está bastante concentrada. Kant e os gregos são quase minha única leitura. Procuro tornarme familiarizado especialmente com a parte estética da filosofia crítica" (Op. Cit., p. 139); carta a Neuffer, de 10.10.1794: "Talvez possa te enviar um ensaio sobre as idéias estéticas [ästhetischen Ideen], [que] pode ser considerado como um comentário sobre o Fedro de Platão. [...] No fundo ele deve conter uma análise do belo e do sublime que [por um lado] simplifica a de Kant, e que, por outro lado, a torna mais multifacetada, tal como já foi feito em parte por Schiller em seu escrito Sobre a graça e a dignidade - o qual, contudo, fica um passo atrás do limite [Grenzlinie] kantiano" (Op. Cit., p. 149-150).
} 
unificação entre teoria (verdade) e prática (bondade) deveria ser efetuada através da beleza. Mas para isso, seria preciso reabilitar a intuição intelectual. Numa carta a Niethammer, de 24.02.1796, ele escreve:

Nas cartas filosóficas, quero encontrar o princípio [Prinzip] que me explique as cisões [Trennungen] nas quais nós pensamos e existimos, mas que também seja capaz de fazer desaparecer o conflito [Widerstreit] entre o sujeito e o objeto, entre nosso Eu [Selbst] e o mundo, e também entre Razão e Revelação, - teoricamente, na intuição intelectual [intellektualer Anschauung], sem que a nossa razão prática tivesse que vir em auxílio. Para isto, necessitamos de sentido estético [ästhetischen Sinn] e irei chamar minhas cartas filosóficas "Novas cartas sobre a educação estética do homem". Ali também passarei da filosofia para poesia [Poesie] e para a religião. ${ }^{267}$

Como se pode perceber, embora Kant tivesse negado, na Crítica da Razão Pura ${ }^{268}$, a possibilidade de uma intuição intelectual [intellektuelle Anschauung], capaz de constituir representações excluindo os sentidos, por meio de uma espontaneidade [Selbsttätigkeit] do entendimento, os filósofos pós-kantianos irão procurar atribuir um novo papel a esse

${ }^{267}$ HÖLDERLIN, F. Sämtliche Werke. Bd. 6 (Briefe). Hg. A. Beck. Stuttgart: Kohlhammer, 1965, p. 219.

${ }^{268} \mathrm{~A}$ esse respeito, ver p. ex.: KrV B 33; "Por intermédio da sensibilidade são-nos dados objetos e só ela nos fornece intuições. [...] O pensamento [...] tem sempre que referir-se [...] a intuições [...], no que respeita a nós, por via da sensibilidade, porque de outro modo nenhum objeto nos pode ser dado"; B 72: "Não querendo considerar o espaço e o tempo formas objetivas de todas as coisas, resta apenas convertê-las em formas subjetivas do nosso modo de intuição [...]; modo que se denomina sensível, porque não é originário, quer dizer, não é um modo de intuição tal, que por ele seja dada a própria existência do objeto da intuição (modo que se nos afigura só poder pertencer ao Ser supremo), antes é dependente da existência do objeto e, por conseguinte, só possível na medida em que a capacidade de representação do sujeito é afetada por esse objeto. [...] apesar dessa universalidade, este modo de intuição não deixa de ser sensibilidade, justamente por ser intuição derivada (intuitus derivativus) e não original (intuitus originarius); não é, portanto, intuição intelectual [intellektuelle Anschauung], como aquela que, pelo fundamento acima exposto, parece só competir ao Ser supremo [...]"; B 92-93 "Ora, independentemente da sensibilidade, não podemos participar em nenhuma intuição. O entendimento não é, pois, uma faculdade de intuição. [...] o conhecimento de todo o entendimento, pelo menos do entendimento humano, é um conhecimento por conceitos, que não é intuitivo, mas discursivo". 
conceito. ${ }^{269}$ Já em 1795, em seu livro Vom Ich als Princip der Philosophie oder über das Unbedingte im menschlichen Wissen [Do Eu como princípio da filosofia ou sobre o incondicionado no saber humano], Schelling afirmava: "Sei muito bem que Kant negou toda intuição intelectual [intellektuale Anschauung]; mas sei também onde ele o fez: numa investigação que em toda parte apenas pressupõe o Eu absoluto". ${ }^{270}$ Nesse mesmo escrito, ele afirma ainda:

O Eu não pode ser dado mediante nenhum mero conceito [Begriff]. Pois conceitos só são possíveis na esfera do condicionado [Sphäre des Bedingten], só [é possível ter conceitos] de obejtos [Objekten]. Se o Eu fosse um conceito, seria preciso haver algo mais elevado, do qual ele tivesse [...] recebido sua unidade. Em uma palavra: o Eu seria completamente condicionado. Conseqüentemente, o Eu só pode ser determinado em uma intuição [Anschauung]. Mas o Eu só é Eu devido ao fato de que ele jamais pode se tornar objeto e, portanto, não pode ser determinado em nenhuma intuição sensível [sinnlichen Anschauung]. Logo, ele só é determinável numa intuição que absoultamente não é sensível, isto é, numa intuição intelectual [intellektualen Anschauung]. - Onde há objeto, há intuição sensível, e vice-versa. Onde não há nenhum objeto, isto é, no Eu absoluto, não há nenhuma intuição sensível, logo, ou não há nenhuma [intuição], ou [há] uma intuição intelectual. Portanto, o Eu é determinado por si mesmo, enquanto mero Eu, na intuição intelectual. ${ }^{271}$

Num estudo acerca da recepção da Terceira Crítica por Fichte e Schelling, Horstmann ${ }^{272}$ afirma que a originalidade deste último estaria justamente na utilização da intuição intelectual na tentativa de resolver os problemas postos a partir Crítica da Razão Pura. ${ }^{273}$ Se é preciso mostrar

${ }^{269}$ Cf. NEUBAUER, J. "Intellektuelle, intellektuale und ästhetische Anschauung". In: Deutsche Vierteljahrsschrift für Literaturwissenschaft und Geistesgeschichte. Vol. 46 (1972), pp. 294-319.

270 SCHELLING, F. W. J. Ausgewählte Schriften I. Frankfurt a.M.: Suhrkamp, 2003, p. I/1, 181.

${ }_{271}$ SCHELLING, F. W. J. Ausgewählte Schriften I, p. I/1, 181.

272 HORSTMANN, R.-P. "Kant hat die Resultate gegeben: Zur Aneignung der Kritik der Urteilskraft durch Fichte und Schelling". In: FULDA, H. F.; HORSTMANN, R.P. Hegel und die Kritik der Urteilskraft. Stuttgart: Klett-Cotta, 1990, pp. 45-65.

${ }^{273}$ HORSTMANN, R.-P. "Kant hat die Resultate gegeben: Zur Aneignung der Kritik der Urteilskraft durch Fichte und Schelling", p. 59. 
que filosofia teórica e filosofia prática provêm de um único princípio, esse princípio tem que ser incondicionado e só podemos ter acesso a ele por intermédio de uma intuição intelectual [intellektuale Anschauung].

\section{Nas Abhandlungen zur Erläuterung des Idealismus der} Wissenschaftslehre [Ensaios para a explicação do idealismo da doutrinada-ciência], escritas entre 1796-97, Schelling esclarece:

Esse conhecimento chama-se intuição [Anschauung], porque ele é sem mediação [unvermittelt]; intelectual, porque ele tem como objeto uma atividade que ultrapassa tudo o que é empírico e que jamais é alcançada mediante conceitos. Pois só há conceitos de objetos e daquilo que é limitado [begrenzt] e que é intuído pelos sentidos. [...] É somente aquela nossa intuição pura de nós mesmos [unsrer selbst] que torna possíveis a unidade objetiva da apercepção e o correlato de toda apercepção, o Eu penso. ${ }^{274}$

Também Fichte chegou a indicar a questão da intuição intelectual ${ }^{275}$, por exemplo, num texto de 1800, intitulado Anúncio de uma nova exposição da doutrina-da-ciência. Ali, Fichte defende que a filosofia seria "um conhecimento da própria razão por si mesma - por intuição", e afirma:

A primeira parte desta definição é a importante descoberta de Kant, que este, contudo, não chegou a executar; a segunda, como condição de possibilidade dessa execução, foi acrescentada pela doutrina da ciência [...]. Só peço que não rejeitem de antemão e sem exame essa idéia, tão logo ouçam pronunciar as palavras doutrinada-ciência e intuição e intuição intelectual (pois é de uma tal intuição

\footnotetext{
${ }^{274}$ SCHELLING, F. W. J. Ausgewählte Schriften I, p. I/1, 401.

275 Acerca da relação entre o filósofo e o gênio na filosofia pós-kantiana, ver especialmente o terceiro capítulo ("A descoberta da arte de filosofar") do livro O gênio romântico, de Márcio Suzuki. Sobre a questão da intuição intelectual, Suzuki comenta que "a genialidade filosófica não é outra coisa que aquilo que a doutrina-da-ciência chama de intuição intelectual - 'o único ponto de vista firme para toda filosofia', a partir do qual 'se deixa esclarecer tudo o que ocorre na consciência' -, ato pelo qual 'o filósofo observa a si mesmo, intui imediatamente seu agir, sabe o que faz, porque ele - o faz!'. A intuição intelectual é o grau supremo de claridade a que pode almejar a filosofia científica. [...] Sem intuição intelectual não se pode pretender explicar as sínteses que a Crítica da Razão Pura descreve como elo entre conceito e intuição. Para a doutrina-daciência, ela é 'absoluta identidade' de ser e liberdade, a 'forma absoluta do saber'" (SUZUKI, M. O gênio romântico, p. 87-88).
} 
que parte a doutrina-da-ciência) [...]. Intuição intelectual, para mim, não é intuição de algo consistente. O que ela seja, justamente porque toda intuição está em um plano superior ao conceito, não pode tornar-se concebível; só é possível travar conhecimento com ela tendo-a. ${ }^{276}$

Mas no Sistema do Idealismo Transcendental (1800), Schelling vai ainda além de Fichte ao exigir que a intuição intelectual, através da qual o filósofo trava conhecimento com a identidade absoluta entre sujeito e objeto, deva ser objetivada. Essa exigência, aparentemente paradoxal, mas necessária para que o sistema se complete $^{277}$, será solucionada através da obra de arte e da intuição estética, na qual Schelling encontrará justamente a intuição intelectual tornada objetiva.

Vejamos, em linhas gerais, como isso se torna possível. Schelling coloca para si a tarefa de encontrar o primeiro princípio [ersten Prinzip] da filosofia, o qual deve ser absolutamente certo e por meio do qual tudo o mais adquire sua certeza. Assim sendo, colocam-se dois problemas para a filosofia. O primeiro deles consiste em explicar a seguinte questão: como as representações podem concordar absolutamente com objetos que existem de maneira totalmente independente delas? Essa é a tarefa da filosofia teórica, a qual tem que investigar a possibilidade da experiência. O segundo problema consiste em explicar: como algo objetivo pode ser modificado mediante algo meramente pensado, de maneira que ele concorde inteiramente com o pensado? Essa é a tarefa da filosofia prática, a qual deve investigar a possibilidade do agir livre.

Com esses dois problemas, diz Schelling, caímos numa contradição, de modo que, com a certeza teórica perdemos a prática e vice-versa: "É impossível que, ao mesmo tempo, haja verdade em nosso conhecimento

${ }^{276}$ FICHTE, J. G. "O Programa da Doutrina-da-Ciência (1800)". In: A Doutrina-da-Ciência de 1794 e outros escritos. Trad. R. R. Torres Filho. São Paulo: Nova Cultural, 1988, p. 192.

${ }^{277}$ SCHELLING, F. W. J. Ausgewählte Schriften I, p. I/3, 349. 
[Erkenntnis] e realidade em nossa vontade [Wollen]". ${ }^{278}$ É preciso, pois, resolver essa contradição; e a tarefa suprema da filosofia consiste justamente na resolução desse problema ou, em outras palavras, na resposta à questão: como podem ser pensadas as representações enquanto orientando-se segundo os objetos e, simultaneamente, como os objetos [podem ser pensados] enquanto orientando-se segundo as representações? ${ }^{279}$

Mas esse problema não pode ser resolvido nem na filosofia teórica, nem na filosofia prática, mas sim, num âmbito mais elevado e que é o elo de ligação entre ambas, e que "não é nem teórico nem prático, mas ambos ao mesmo tempo". ${ }^{280}$

Assim, torna-se necessário encontrar o produto de uma atividade simultaneamente consciente e inconsciente (ou seja: subjetiva e objetiva ao mesmo tempo). Além disso, Schelling observa que o sistema do saber deve estar completo quando ele volta ao ponto de onde partiu, ao seu princípio. Como a filosofia transcendental parte do Eu, ela só está completa quando se puder mostrar aquela identidade no seu princípio (no Eu). Por isso ele postula que "na consciência mesma, mostra-se essa atividade simultaneamente consciente e inconsciente". ${ }^{281}$ E qual é essa atividade? A resposta de Schelling é:

Uma tal atividade só pode ser a [atividade] estética, e cada obra de arte só pode ser compreendida enquanto produto de uma tal [atividade]. O mundo ideal da arte e o mundo real dos objetos são, portanto, produtos de uma e mesma atividade. [...] O mundo objetivo é apenas a poesia [Poesie] originária e ainda inconsciente do espírito [Geist]; o órgão universal [allgemeine Organon] da filosofia - e sua

\footnotetext{
${ }^{278}$ SCHELLING, F. W. J. Ausgewählte Schriften I, p. I/3, 348.

${ }^{279}$ SCHELLING, F. W. J. Ausgewählte Schriften l, p. I/3, 348.

${ }^{280}$ SCHELLING, F. W. J. Ausgewählte Schriften I, p. I/3, 348.

${ }^{281}$ SCHELLING, F. W. J. Ausgewählte Schriften I, p. I/3, 349.
} 
chave de abóbada [Schlußstein ihres Gewölbes] - é a filosofia da arte. $^{282}$

Schelling afirma que esse agir [Handeln] só pode ser apreendido mediante uma "intuição interna imediata" [unmittelbare innere Anschauung], pois, uma vez que o único objeto imediato da consideração transcendental é o subjetivo [das Subjektive], "o único órgão [Organ] desse modo de filosofar é o sentido interno [innere Sinn]" e seu objeto [Objekt] não pode ser uma intuição externa [äußern Anschauung]". 283

Assim, é o ato estético da imaginação que torna possível a reflexão do absolutamente inconsciente e não objetivo:

Assim como a arte, também a filosofia se baseia na faculdade produtiva [produktiven Vermögen], e a distinção entre ambas consiste meramente na diferença de direção da força produtiva [produktiven Kraft]. Pois enquanto a produção na arte se orienta em direção ao exterior [nach außen sich richtet], para refletir o inconsciente mediante produtos, a produção filosófica se orienta imediatamente em direção ao interior, para refleti-lo em uma intuição intelectual [in intellektueller Anschauung]. - O sentido [Sinn] próprio, com o qual esse modo [Art] da filosofia tem que ser apreendido é, portanto, o [sentido] estético, e justamente por isso a filosofia é o verdadeiro órganon da filosofia. ${ }^{284}$

É preciso encontrar na inteligência uma intuição [Anschauung] através da qual "o Eu seja para si mesmo consciente e inconsciente simultaneamente", pois é somente através de uma intuição como esta que o problema supremo da filosofia transcendental - a saber, o acordo do subjetivo e do objetivo - pode ser solucionado. ${ }^{285}$ Essa intuição, na qual a atividade consciente e inconsciente se objetiva "em uma e na mesma

\footnotetext{
282 SCHELLING, F. W. J. Ausgewählte Schriften I, p. I/3, 349.

283 SCHELLING, F. W. J. Ausgewählte Schriften I, p. I/3, 350.

284 SCHELLING, F. W. J. Ausgewählte Schriften I, p. I/3, 351.

285 SCHELLING, F. W. J. Ausgewählte Schriften I, p. I/3, 610-611.
} 
intuição [in einer und derselben Anschauung]" e na qual o Eu é para si mesmo consciente e inconsciente ao mesmo tempo, nada mais é que a intuição artística [Kunstanschauung]. E a sexta e última parte do Sistema do Idealismo Transcendental de Schelling se volta justamente para a dedução e análise dessa intuição.

Ora, essa intuição artística deve reunir aquilo que existe separadamente no fenômeno da liberdade e na intuição do produto da natureza, a saber: a "identidade do consciente e do inconsciente no Eu" e a "consciência dessa identidade": "o produto dessa intuição terá seus limites, por um lado, no produto da natureza, e por outro lado, no produto da liberdade, e precisará unir em si os caracteres de ambos", ou seja, é necessário que 0 produto ${ }^{286}$ dessa união seja capaz de unir em si os traços distintivos tanto da natureza (teoria) quanto da liberdade (prática). E o que esse produto tem em comum com o produto da liberdade? É o fato dele ter sido produzido com consciência [mit Bewußtsein] - ou seja, é o contrário do produto orgânico da natureza. $\mathrm{E}$ o que ele tem em comum com o produto da natureza? É o fato dele ter sido produzido sem consciência [bewußtlos], como uma atividade cega. Como isso é possível? Como resolver essa aparente contradição? De que maneira liberdade e necessidade podem ser unidas de maneira absoluta? "É preciso haver um ponto", diz Schelling, "em que ambas coincidam [zusammenfallen]". ${ }^{287}$ Portanto, é preciso que a produção seja livre, mas que o produto apareça como identidade absoluta da atividade livre e da atividade necessária. Ora, esse produto nada mais é do que o produto do gênio, "e como o gênio só é possível na arte", o produto postulado é

\footnotetext{
${ }^{286}$ Schelling afirma que, se conhecermos o produto dessa intuição, conheceremos a intuição mesma, de modo que "precisamos deduzir apenas o produto para deduzir a intuição". SCHELLING, F. W. J. Ausgewählte Schriften I, p. I/3, 612.

${ }^{287}$ SCHELLING, F. W. J. Ausgewählte Schriften I, p. I/3, 614.
} 
justamente o produto artístico [Kunstprodukt]. ${ }^{288}$ É na obra de arte que liberdade e necessidade, sujeito e objeto aparecem unidos:

Que toda produção estética se baseia numa oposição [Gegensatz] de atividades, pode-se deduzir com razão já a partir dos testemunhos de todos os artistas, de que eles são involuntariamente impelidos [unwillkürlich getrieben] à produção de suas obras e que através da produção das mesmas eles apenas satisfazem um impulso irresistível [unwiderstehlichen Trieb]. ${ }^{289}$

Sendo a arte algo consumado mediante duas atividades completamente distintas, aquele que a produz - o gênio - está acima de ambas. No gênio, consciente e inconsciente encontram-se inseparavelmente reunidos. Aquilo a que os Antigos denominavam téchne - ou seja, a parte da arte que pode ser ensinada e aprendida, que pode ser exercitada com consciência [Bewußtsein] e reflexão - deve estar associada a um inconsciente [Bewußtlos], a algo que não pode ser aprendido nem alcançado através de exercício, mas que é inato, um livre dom da natureza. Nem uma, nem outra dessas partes constituintes da arte pode reivindicar a superioridade com relação à outra, uma vez que é somente a união de ambas que produz o supremo na arte. ${ }^{290}$

Uma vez que o gênio é aquele que manifesta essa unidade originária entre consciente e inconsciente, Schelling irá considerar que o gênio está para a estética assim como o Eu está para a filosofia. Ele é o "supremo e absoluto Real" [das Höchste absolut Reelle], aquilo que embora nunca se torne objetivo é, contudo, "causa de todo o Objetivo" [Ursache alles Objektiven]. ${ }^{291}$

\footnotetext{
288 SCHELLING, F. W. J. Ausgewählte Schriften I, p. I/3, 616.

289 SCHELLING, F. W. J. Ausgewählte Schriften I, p. I/3, 616.

290 Schelling comenta um pouco mais adiante, que nenhuma tem a prioridade com relação à outra, e que é justamente a indiferença de ambas - entre arte e poesia, ou em outras palavras, entre técnica e dom - que se reflete na obra de arte. Cf. SCHELLING, F. W. J. Ausgewählte Schriften I, p. I/3, 619 (nota 1).

291 SCHELLING, F. W. J. Ausgewählte Schriften I, p. I/3, 619.
} 
Tendo estabelecido essa analogia entre o gênio e o Eu absoluto, Schelling passa, então, a analisar o caráter do produto artístico em geral.

Como já foi mencionado, a obra de arte, enquanto síntese da natureza e da liberdade, reflete a "identidade da atividade consciente e inconsciente". Uma vez que a oposição entre ambas é infinita, Schelling conclui que, da mesma forma, o caráter fundamental de uma obra de arte é uma "infinitude inconsciente" [bewußtlose Unendlichkeit] ${ }^{292}$.

Além daquilo que ele colocou na obra de maneira evidentemente intencional, o artista parece instintivamente ter exposto, por assim dizer, uma infinitude [Unendlichkeit], a qual nenhum entendimento finito [endlicher Verstand] é capaz de desenvolver completamente. ${ }^{293}$

É impossível não perceber aqui a retomada do conceito kantiano de "idéia estética", a saber, aquela representação da faculdade da imaginação que dá muito a pensar, mas à qual nenhum conceito é inteiramente adequado. Essa influência fica ainda mais evidente, se lembrarmos que na Crítica da Faculdade do Juízo, uma das principais características da figura do gênio era justamente a capacidade de exposição de idéias estéticas. ${ }^{294}$ É graças a essa inadequação a conceitos que caracteriza a idéia estética que Schelling irá se basear para afirmar que as verdadeiras obras de arte contêm em si um sentido infinito e que as palavras e conceitos não conseguem dar conta.

Outra característica marcante da obra de arte, e que será de enorme importância para o pensamento do primeiro romantismo, está no fato de que toda produção estética parte de uma cisão infinita em-si [an sich unendlichen Trennung] das duas atividades (consciente e inconsciente). Mas, uma vez que ambas atividades devem ser apresentadas enquanto

\footnotetext{
${ }^{292}$ SCHELLING, F. W. J. Ausgewählte Schriften I, p. I/3, 619.

${ }^{293}$ SCHELLING, F. W. J. Ausgewählte Schriften I, 2003, p. I/3, 619.

294 Cf. KANT, KdU, § 57, Observação 1, B 242: "Em conseqüência disso podemos explicar o gênio também pela faculdade de idéias estéticas, com o que é ao mesmo tempo indicada a razão pela qual, em produtos do gênio, a natureza (do sujeito) e não um fim refletido dá a regra à arte (à produção do belo)".
} 
reunidas no produto artístico, Schelling irá concluir que através da obra de arte um infinito é exposto finitamente [ein Unendliches endlich dargestellt]. Esse infinito exposto de maneira finita nada mais é que a própria beleza [Schönheit], sem a qual não há obra de arte. ${ }^{295} \mathrm{Em}$ outras palavras, toda obra de arte genuína é bela, na medida em que ela expõe finitamente o infinito.

Após haver determinado as características da obra de arte, é preciso investigar ainda em que estas se distinguem de outros produtos. Schelling irá se concentrar na distinção do produto estético em relação: 1) ao produto da natureza (organismo); 2) ao produto artístico vulgar [gemeinen Kunstprodukt] e, por fim, 3) à ciência.

Com relação ao primeiro ponto, as observações de Schelling trarão, como iremos ver, conseqüências importantes para a estética posterior (sobretudo no que diz respeito à doutrina da arte como imitação da natureza). Ele aponta duas diferenças fundamentais entre os produtos da arte e os produtos da natureza:

a) o ser orgânico [organische Wesen] expõe [darstellt] ainda indiviso [ungetrennt], o que a produção estética expõe - unificado [vereinigt] - após a cisão [Trennung]; b) a produção orgânica não parte da consciência [Bewußtsein], e portanto, não parte da contradição infinita [unendlichen Widerspruch], que é a condição [Bedingung] da produção estética. Assim, se a beleza é inteiramente a dissolução [Auflösung] de um conflito [Widerstreit] infinito, logo, o produto orgânico da natureza não será necessariamente belo, e quando o for, a beleza aparecerá como totalmente casual [schlechthin zufällig], pois a sua condição [Bedingung] não pode ser pensada enquanto existente. ${ }^{296}$

Com essa última distinção, e a determinação do belo natural como sendo algo de natureza meramente casual, Schelling está rompendo com o privilégio que o belo na natureza possuía na Terceira Crítica e, ao mesmo tempo, já aponta para a concepção hegeliana da estética como

\footnotetext{
295 SCHELLING, F. W. J. Ausgewählte Schriften I, p. I/3, 620.

${ }^{296}$ SCHELLING, F. W. J. Ausgewählte Schriften I, p. I/3, 622.
} 
ciência dedicada exclusivamente ao belo da arte. ${ }^{297}$ Outra conseqüência importante, como mencionamos acima, diz respeito à concepção da arte como imitação da natureza: ao invés desse belo "meramente casual" da natureza fornecer as regras para a arte é, antes, tudo aquilo que a arte "produz em sua perfeição [Vollkommenheit], que é princípio e norma para o ajuizamento da beleza natural". 298

A segunda distinção feita por Schelling, a saber, entre o produto estético [ästhetische Produkt] e o produto artístico vulgar [gemeinen Kunstprodukt] consiste primordialmente no fato de que a produção estética é absolutamente livre em seu princípio. Na linguagem kantiana, poder-se-ia dizer que o produto artístico vulgar (no qual poder-se-ia englobar os artefatos meramente técnicos) possui uma finalidade externa a si, enquanto o produto estético obedece a uma finalidade interna, uma "finalidade sem fim". Dessa independência com relação a fins externos origina-se, segundo Schelling, "aquela santidade [Heiligkeit] e pureza [Reinheit] da arte". Ele chega mesmo a afirmar que a verdadeira arte não apenas rejeita qualquer parentesco com o mero prazer dos sentidos [Sinnenvergnügen] e com o útil [Nützlichen], mas rejeita também o parentesco com tudo aquilo que pertence ao âmbito da Moralidade e das ciências. ${ }^{299}$ É justamente a distinção entre arte e ciência - ou, em outras palavras, entre arte e conhecimento teórico - que constitui o terceiro ponto abordado pelo autor. A seu ver, arte e ciência são tão opostas em suas tendências, pois:

\footnotetext{
${ }^{297}$ Logo no início de seu curso de estética, Hegel afirma: "Estas lições são dedicadas à estética, cujo objeto é o amplo reino do belo; de modo mais preciso, seu âmbito é a arte, na verdade, a bela arte". E um pouco adiante: "[...] o belo artístico está acima da natureza. Pois a beleza artística é a beleza nascida e renascida do espírito". Cf. HEGEL, G. W. F. Vorlesungen über die Ästhetik I. Frankfurt a.M.: Suhrkamp, 1986, p. 13-14. Trad. Brasileira: Cursos de Estética I. Trad. M. A. Werle. São Paulo: Edusp, 2001.

${ }^{298}$ SCHELLING, F. W. J. Ausgewählte Schriften I, p. I/3, 622.

${ }^{299}$ SCHELLING, F. W. J. Ausgewählte Schriften I, p. I/3, 622-23.
} 
Embora a ciência, em sua função suprema, possua uma e a mesma tarefa que a arte, no entanto, devido à sua maneira de solucioná-la, tal tarefa é infinita para a ciência, de modo que se pode dizer que a arte seria o modelo [Vorbild] da ciência, e que esta deve chegar onde a arte está. ${ }^{300}$

Em outras palavras, a arte fornece de maneira imediata, através de uma intuição estética, aquilo que, no âmbito da teoria, só pode ser concebido como uma "aproximação infinita". Também Hölderlin, alguns anos antes, expressava um ponto de vista semelhante numa carta a Schiller (datada de 04 de setembro de 1795). Ali, Hölderlin apontava que a exigência de uma união entre sujeito e objeto num Eu absoluto seria possível "esteticamente, na intuição intelectual [intellektualen Anschauung]" - mas teoricamente ela só seria possível numa "aproximação infinita" [unendliche Annäherung]. ${ }^{301}$ Dada a proximidade entre Hölderlin e Schelling, é bastante provável que o último capítulo do "Sistema do Idealismo Transcendental" seja uma tentativa de se chegar a uma solução para aquelas questões compartilhadas pelos três Stiftler de Tübingen, e que já se encontravam esboçadas no "Mais antigo programa de sistema do Idealismo alemão". ${ }^{302}$

\footnotetext{
${ }^{300}$ SCHELLING, F. W. J. Ausgewählte Schriften I, p. I/3, 623.

${ }^{301}$ HÖLDERLIN, F. Sämtliche Werke VI. Stuttgart: W. Kohlhammer, 1965, p. 196-97. A citação original é a seguinte: "[...] ich suche mir die Idee eines unendlichen Progresses der Philosophie zu entwickeln, ich suche zu zeigen, daß die unnachläßliche Forderung, dia an jedes System gemacht werden muß, die Vereinigung des Subjekts und Objekts in einem absoluten - Ich oder wie man es nennen will - zwar ästhetisch, in der intellektualen Anschauung, theoretisch aber nur durch eine unendliche Annäherung möglich ist".

${ }^{302}$ Cabe lembrar ainda que o papel elevado ocupado pela beleza e a relação entre filosofia e poesia são retomados também por Hölderlin no Livro II do Hipérion: "A poesia - respondi seguro de minha opinião - é o começo e o fim dessa ciência [a saber, da filosofia]. Ela se origina da poesia de um ser divino, como Minerva da cabeça de Júpiter. E desse modo, afinal, o incompatível conflui novamente para ela, para a fonte misteriosa da poesia. [...] A grandiosa frase de Heráclito, hèn diaphéron heautôi [o uno diferente em si mesmo] só poderia ser encontrada por um grego, pois é a essência da beleza e, antes de ter sido encontrada, não havia filosofia alguma". Cf. HÖLDERLIN, F. Hipérion ou o eremita na Grécia. Trad. E. J. Paschoal. São Paulo: Nova Alexandria, 2003, p. 85.
} 
No que concerne ao papel do gênio na arte e na ciência, Schelling parece retomar o ponto de vista defendido por Kant no $\S 47$ da Crítica do Juízo: tendo afirmado que o gênio se opõe totalmente ao espírito de imitação, e visto que aprender não é senão imitar, Kant argumenta que mesmo as maiores descobertas no campo da ciência - como as leis newtonianas da gravitação universal - não podem ser consideradas como produtos do gênio, uma vez que a ciência se situa no âmbito da reflexão segundo regras, sendo possível ensiná-las e aprendê-las:

Assim se pode bem aprender tudo o que Newton expôs na sua obra imortal Princípios de Filosofia Natural, por grande que fosse a cabeça que a descoberta de tais coisas exigia; mas não se pode aprender a escrever com engenho, por mais minuciosos que possam ser todos os preceitos de arte poética [...]. Newton poderia mostrar [...] a qualquer outro e seus sucessores [...] todos os passos que ele tinha a dar desde os primeiros elementos da geometria até às suas grandes e profundas descobertas; mas nenhum Homero ou Wieland pode indicar como as suas idéias imaginosas, e ao mesmo tempo cheias de pensamento, surgem e se reúnem em sua cabeça. ${ }^{303}$

Schelling, por sua vez, não nega que um problema científico possa ser solucionado de maneira genial; mas, no entanto, ele observa ainda que essa mesma tarefa pode ser solucionada também de maneira mecânica. Contudo, o mesmo não se passa no caso da produção de uma obra de arte: esta é possível "apenas e tão somente através do gênio", pois em toda tarefa solucionada pela arte, há a união de uma contradição infinita [unendlicher Widerspruch]. ${ }^{304}$ A diferença fundamental é entre possibilidade e necessidade: a ciência pode ser produzida pelo gênio, mas apenas uma obra de arte genuína é um produto necessário do gênio e de sua atividade que reúne o consciente e o insconsciente, a

\footnotetext{
${ }^{303}$ KANT, KdU, § 47, B 183-84.

${ }^{304}$ SCHELLING, F. W. J. Ausgewählte Schriften I, p. I/3, 623.
} 
necessidade e a liberdade, e cujo produto é uma síntese entre o sujeito e o objeto.

Assim, o gênio se distingue do mero talento [Talent] e da habilidade [Geschicklichkeit] pelo fato de que através dele se resolve "uma contradição que absolutamente não pode ser solucionada através de mais nada". A produção estética tem como condição [Bedingung] "uma oposição infinita" [unendlicher Gegensatz] da atividade consciente e da atividade insconsciente e, portanto, é possível "somente através do gênio". ${ }^{305}$

Tendo determinado a essência e as características do produto da arte, Schelling passa então a examinar a relação da filosofia da arte com o sistema da filosofia em seu todo. Tendo em vista que a filosofia parte e deve partir - de um princípio [Princip] "absolutamente idêntico" e totalmente não-objetivo [schlechthin nichtobjektiv], é preciso investigar a seguinte questão: "como esse Não-Objetivo absoluto [absolut Nichtobjektive] deve ser compreendido e trazido à consciência (o que é necessário), tendo em vista que ele é condição para a compreensão de toda a filosofia?". 306

É evidente que esse princípio incondicionado da filosofia não pode ser apreendido nem exposto mediante conceitos: ele pode apenas ser intuído. Desse modo, diz Schelling, "não resta mais nada, a não ser expôlo numa intuição imediata [unmittelbaren Anschauung], a qual é, de novo, ela mesma, inapreensível [unbegreiflich]", ou seja, esse primeiro princípio não pode ser explicado por nenhum outro, pois, do contrário, ele necessitaria de um outro princípio, e assim infinitamente. Desse modo, esse primeiro princípio absolutamente idêntico só pode ser apreendido de maneira imediata, por meio de uma intuição intelectual. Com efeito, essa

\footnotetext{
305 SCHELLING, F. W. J. Ausgewählte Schriften I, p. I/3, 624.

${ }^{306}$ SCHELLING, F. W. J. Ausgewählte Schriften I, p. I/3, 624-625.
} 
intuição - que não é uma intuição sensível, mas sim uma intuição intelectual - é uma intuição meramente interior. Seu objeto [Gegenstand] não é nem o objetivo [Objektive] nem o subjetivo [Subjektive], mas sim o absolutamente Idêntico [das absolut Identische]. "Uma tal intuição", diz Schelling, "é o órgão de toda a filosofia [das Organ aller Philosophie]". ${ }^{307}$ Mas isso conduz a uma segunda questão: se há, de fato, essa intuição intelectual, como posso garantir que ela não se baseia numa ilusão [Täuschung] subjetiva? Em outras palavras, para que essa intuição intelectual seja considerada como algo indubitável, é preciso que ela própria se objetive de alguma forma, ou seja, é preciso que haja uma forma universal de objetividade dessa intuição intelectual, e que possa ser reconhecida por todos os homens. Para Schelling, a intuição intelectual só pode se tornar objetiva através de uma segunda intuição, a saber, através da intuição estética. Dessa forma, essa objetividade "universalmente reconhecida" da intuição intelectual nada mais é do que a própria Arte; e a intuição estética nada mais é do que intuição intelectual que se tornou objetiva: $^{308}$

A obra de arte apenas reflete para mim aquilo que não é refletido por mais nada, aquele Idêntico absoluto [absolut Identische], que mesmo no Eu já se dividiu; assim, aquilo que para o filósofo já se divide no primeiro ato da consciência [Akt des Bewußtseins], e que é, de outra forma, inacessível a qualquer intuição [Anschauung], resplandece através do milagre da arte [Wunder der Kunst], a partir de seus produtos. ${ }^{309}$

Mas a importância da arte no Sistema do Idealismo Transcendental não se restringe apenas ao fato dela objetivar o primeiro princípio da filosofia e a primeira intuição (intuição intelectual) da qual ela parte. Para Schelling, "o mecanismo todo [der ganze Mechanismus] que a filosofia

\footnotetext{
${ }^{307}$ SCHELLING, F. W. J. Ausgewählte Schriften I, p. I/3, 625, nota.

${ }^{308}$ SCHELLING, F. W. J. Ausgewählte Schriften I, p. I/3, 625.

${ }^{309}$ SCHELLING, F. W. J. Ausgewählte Schriften I, p. I/3, 625.
} 
deduz, e sobre o qual ela mesma repousa, só se torna objetivo através da produção estética". ${ }^{310}$ Assim como a filosofia parte de uma "divisão infinita [unendlichen Entzweiung] de atividades opostas [entgegengesetzter Tätigkeiten]", da mesma forma, toda produção estética está baseada "nesta mesma divisão", a qual, no entanto, é completamente suprimida [aufgehoben] através de cada representação da arte. ${ }^{311}$ A faculdade produtiva - que Schelling chama de faculdade artística [Kunstvermögen] consegue realizar aquilo que, à primeira vista pareceria impossível: suprimir uma oposição infinita em um produto finito, isto é, numa obra de arte, que consegue expor aquele infinito de maneira finita.

Ainda acerca da relação da filosofia da arte com o sistema da filosofia em seu todo, Schelling irá examinar a concepção da arte como único órganon e documento da filosofia ${ }^{312}$ :

Se a intuição estética é tão somente a [intuição] intelectual tornada objetiva, então compreende-se por si só, que a arte seria simultaneamente o único, verdadeiro e eterno órganon e documento [Dokument] da filosofia, e que comprova [beurkundet] sempre e ininterruptamente, aquilo que a filosofia não pode expor exteriormente, a saber, o inconsciente [das Bewußtlose] no agir e produzir e sua identidade originária [ursprüngliche Identität] com o consciente [Bewußten]. Justamente por isso a arte é, para o filósofo, o supremo [das Höchste], pois ela lhe abre, por assim dizer, o que há de mais sagrado [das Allerheiligste], onde se refugia, numa união [Vereinigung] eterna e originária [...], aquilo que está separado na natureza e na história. ${ }^{313}$

\footnotetext{
${ }^{310}$ SCHELLING, F. W. J. Ausgewählte Schriften I, p. I/3, 625-626.

${ }^{311}$ SCHELLING, F. W. J. Ausgewählte Schriften I, p. I/3, 626.

${ }^{312}$ A respeito dessa célebre passagem, Tilliette comenta que a arte cumpre uma tarefa tripla com relação à filosofia: 1) enquanto documento: "atestado, testemunha e carta de criação, fonte de conhecimento e objeto de investigação"; 2) órgão (e não cânon): "ferramenta, instrumento [...] espelho vivo de seu conceito", 3) chave de abóbada do sistema inteiro: "a arte é o representante, a hipotipose (exibição, exposição) do supremo e do absoluto para o filósofo transcendental". Cf. TILLIETTE, X. L'Absolu et la philosophie: essais sur Schelling. Paris: PUF, 1987, p. 94.

${ }^{313}$ SCHELLING, F. W. J. Ausgewählte Schriften I, p. I/3, 627-628.
} 
Com isso, Schelling retorna ao ponto de onde havia partido, concluindo assim seu sistema: pois o princípio originário da filosofia - a saber, aquela identidade originária entre subjetivo e objetivo, que só podia ser apreendida por meio da intuição intelectual - é o mesmo que se torna totalmente objetivo por meio da obra de arte (produzida pelo sujeito genial). "Se a arte é a única", escreve Schelling, "que consegue fazer objetivamente e com validade universal aquilo que o filósofo só consegue expor subjetivamente [subjektiv darzustellen]" então devemos esperar que a poesia finalmente adquira aquela dignidade superior, como mestra da humanidade (tal como já se havia esboçado no "Mais antigo programa de sistema") ${ }^{314}$. Nas palavras do autor, "tal como a filosofia, na infância da ciência, nasceu da poesia [Poesie] e foi por ela nutrida", é de se esperar que, juntamente com as outras ciências, ela deságüe "no oceano universal da poesia, do qual elas haviam partido". ${ }^{315}$ Daí a necessidade de uma nova Mitologia ${ }^{316}$, que atue como "elo intermediário" [Mittelglied] para esse retorno da ciência em direção à poesia. ${ }^{317}$

Se é certo afirmar que o Sistema do Idealismo Transcendental em sua totalidade está situado entre dois extremos - a intuição intelectual e a intuição estética - podemos afirmar também que filosofia e arte são, na verdade, os dois lados da mesma moeda: pois, se subtraíssemos da arte a sua objetividade [Objektivität], ela deixaria de ser o que é e se tornaria

314 "Das sogenannte Älteste Systemprogramm". In: FRANK, M.; KURZ, G. (Hg). Materialien zu Schellings philosophischen Anfängen. Frankfurt a.M.: Suhrkamp, 1975, p. 111 (trad. Brasileira de R. Rodrigues Torres Filho. In: SCHELLING, F.W.J. Obras escolhidas. São Paulo: Abril Cultural, 1984, p. 43).

${ }^{315}$ SCHELLING, F. W. J. Ausgewählte Schriften l, p. I/3, 629.

${ }^{316}$ Cabe notar que também essa necessidade de uma nova mitologia já estava prefigurada no final do "Mais antigo sistema": "Temos de ter uma nova mitologia, mas essa mitologia tem de estar a serviço das Idéias, tem de se tornar uma mitologia da Razão". Cf. "Das sogenannte Älteste Systemprogramm". In: FRANK, M.; KURZ, G. (Hg). Materialien zu Schellings philosophischen Anfängen. Frankfurt a.M.: Suhrkamp, 1975, p. 111 (trad. Brasileira de R. Rodrigues Torres Filho. In: SCHELLING, F.W.J. Obras escolhidas. São Paulo: Abril Cultural, 1984, p. 43).

${ }^{117}$ Somente em 1842 é que Schelling irá publicar sua Philosophie der Mythologie (Filosofia da mitologia). 
filosofia. Da mesma forma, se déssemos objetividade à filosofia, ela deixaria de ser filosofia e se tornaria arte. ${ }^{318}$ "É certo que a filosofia alcança o supremo [das Höchste]", mas somente uma pequena parte da humanidade - a saber: os filósofos - consegue chegar até esse ponto: ao infinito, ao incondicionado. Já a arte "conduz a humanidade toda, tal como ela é, ao conhecimento do supremo [Erkenntnis des Höchsten], e nisso consiste a eterna distinção [entre arte e filosofia] e o milagre da arte [das Wunder der Kunst]" ${ }^{319}$

No Sistema do Idealismo Transcendental de Schelling a arte se eleva acima de todos os demais objetos. Além de retomar e desenvolver diversos temas que já estavam indicados no "Primeiro programa de sistema", pode-se perceber nesse último capítulo dedicado à arte e à intuição estética, como bem notou Tilliette, ecos de Goethe, Moritz, Fichte, dos irmãos Schlegel e de Novalis. ${ }^{320}$ Com efeito, Tilliette defende a hipótese de que o contato de Schelling com os irmãos Schlegel, Fichte, Novalis e Tieck, ocorrido durante o ano de 1798 em Dresden teria sido decisivo na elaboração dessas páginas. Para Tilliette, o final do Sistema do Idealismo Transcendental "seria inconcebível" sem esses encontros. ${ }^{321}$ Acerca de uma possível influência dos Herzensergießungen, ele comenta que, embora não tenha podido conhecer Wackenroder (falecido prematuramente naquele mesmo ano), Schelling travou contato com Tieck e, embora não se possa atestar que ele tenha lido os

\footnotetext{
${ }^{318}$ SCHELLING, F. W. J. Ausgewählte Schriften I, p. I/3, 630.

${ }^{319}$ SCHELLING, F. W. J. Ausgewählte Schriften I, p. I/3, 630.

${ }^{320}$ Tilliette desenvolve esse ponto de vista no quinto capítulo ("La philosophie de l'art") de seu livro: TILLIETTE, X. L'absolu et la philosophie: essais sur Schelling. Paris: PUF, 1987, em especial às páginas 92-95.

${ }^{321}$ TILLIETTE, X. Recherches sur l'intuition intellectuelle de Kant à Hegel. Paris: Vrin, 1995.
} 
Herzensergießungen, essa é, no entanto uma hipótese bastante provável, dados os inúmeros indícios no uso do vocabulário. ${ }^{322}$

Mas de qualquer forma, independentemente das possíveis influências que possam ter se exercido sobre Schelling quando da redação da última parte seu Sistema do Idealismo Transcendental, devese notar aqui que o elevado valor adquirido pela arte é concedido graças à sua importância no interior desse mesmo sistema, no qual ela é a "chave de abóbada", sua parte superior e central e que arremata o todo da construção. Como bem observou Tilliette:

A arte, na aparição genial, resolve a aporia que divide o Eu e o mundo, a liberdade e a natureza, a consciência e o inconsciente. $\mathrm{O}$ gênio cria livremente aquilo que ele produz e efetua necessariamente aquilo que ele concebe livremente. Essa síntese que concilia os antagonismos e desvela o Absoluto indiviso sob as oposições refletese na obra, que é o receptáculo do infinito sob uma forma finita. ${ }^{323}$

Resultado da ação do gênio, a arte consegue realizar aquilo que parecia inconcebível: ser a síntese entre natureza e liberdade, a identidade originária entre sujeito e objeto, expondo o infinito no finito.

\footnotetext{
${ }^{322}$ Cf. SCHELLING, F.W. J. Ausgewählte Schriften I, p. I/3, 628: a arte como "o supremo [das Höchste]", que revela ao filósofo "o que há de mais sagrado [das Allerheiligste]"; a natureza caracterizada como "um poema" escrito "numa maravilhosa linguagem misteriosa" [in geheimer wunderbarer Sprache]. Um pouco mais adiante $(1 / 3,630)$, ele volta a falar no "milagre da arte" [das Wunder der Kunst].

${ }^{323}$ TILLIETTE, X. Recherches sur l'intuition intellectuelle de Kant à Hegel. Paris: Vrin, 1995, p. 125.
} 


\title{
V. A RECEPÇÃO DA CRÍTICA DO JUÍZO PELOS TEÓRICOS E CRÍTICOS MUSICAIS
}

\begin{abstract}
"A revolução no mundo filosófico abalou o fundamento sobre o qual a estética estava assentada, e seu sistema anterior, se é que se pode dar-lhe esse nome, foi deixado em ruínas. [...] Em sua Crítica do Juízo Kant já começou a aplicar os princípios da filosofia crítica ao gosto e, se não forneceu, pelo menos preparou os fundamentos para uma nova teoria da arte". ${ }^{324}$
\end{abstract}

Após termos visto de que maneira tornou-se possível que a experiência estética e a arte em geral adquirissem uma importância suprema para a filosofia, é preciso agora examinar de que modo a música - e em especial a música puramente instrumental - adquire importância e se torna modelo para as demais artes. ${ }^{325}$ Para tanto, procuraremos ver como a concepção kantiana de uma hierarquia das artes foi recebida por alguns teóricos e críticos musicais. Nosso objetivo aqui não será o de

\footnotetext{
324 Carta de Schiller ao Príncipe de Augustenburg (09.02.1793). SCHILLER, F. "Augustenburger Briefe". In: Über die ästhetische Erziehung des Menschen. Hg. K. Berghahn. Stuttgart: Reclam, 2000, p. 128.

325 Schopenhauer, por exemplo, irá considerar a música como "a rainha das artes", de sorte que "o objetivo de toda arte é tornar-se como a música" [grifos meus] (Cf. SCHOPENHAUER, A. Handschrifter Nachlaß Bd. IV (Neue Paralipomena). Hrsg. E. Grisebach. Leipzig: Reclam, 1931, p. 31).
} 
examinar pormenorizadamente as concepções musicais de Kant - o que exigiria um exame mais detido não apenas dos trechos dedicados à música na Crítica do Juízo e na Antropologia, mas também das reflexões, cartas e apontamentos de aulas feitos por seus alunos. Nosso propósito é mais modesto e consiste apenas em tentar reconstituir, em linhas bastante gerais, a maneira pela qual a estética de Kant foi compreendida e interpretada nos primórdios do século XIX.

\section{A ambigüidade da música: arte bela ou meramente agradável?}

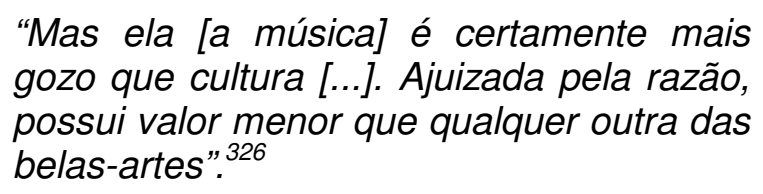

Pode-se afirmar, sem risco de exagero, que a recepção dos escritos kantianos referentes à música foi marcada por uma série de malentendidos. Como o musicólogo Stephan Nachtsheim procurou apontar, "desde os ataques de Herder, Kant é tido como o protótipo do especulador que não tem idéia do que diz em matéria de música". ${ }^{327}$ No entanto, estudos recentes têm demonstrado que se deveria ter mais cautela ao afirmar uma suposta indiferença de Kant pela música ou falta de conhecimento das discussões musicais de sua época. Pelo contrário, as reflexões kantianas publicadas postumamente trazem indícios de sua

\footnotetext{
${ }^{326}$ KANT, KdU § 53, B 218.

${ }^{327}$ NACHTSHEIM, S. Zu Immanuel Kants Musikästhetik. Chemnitz: Gudrun Schröder, 1997, p. 7.
} 
familiaridade com os textos sobre música de Rameau ${ }^{328}$, Rousseau, D'Alembert, Werckmeister ${ }^{329}$, Leibniz, Euler, Sulzer, dentre outros. Mas para o debate estético de sua época, os textos mais influentes de Kant foram, sem dúvida a Crítica do Juízo e a Antropologia.

Nos parágrafos dedicados à comparação do valor estético das belas-artes entre si na Crítica do Juízo, Kant atribui um lugar pouco elevado à música, pois considera que, em toda arte bela, o essencial consiste na forma e não na matéria da sensação disposta apenas para a fruição:

Pois em toda a bela arte o essencial consiste na forma [Form], que convém à observação e ao julgamento [Beurteilung] e cujo prazer [Lust] é, ao mesmo tempo, cultura [Kultur] e dispõe o espírito para idéias [...]; não consiste na matéria da sensação [Materie der Empfindung] (no atrativo ou na comoção), disposta apenas para o gozo [Genuß], o qual não deixa nada para a idéia, torna o espírito embotado, o objeto pouco a pouco repugnante e o ânimo insatisfeito consigo e instável [...] ${ }^{330}$

Apesar de reconhecer a forma ${ }^{331}$ nos fundamentos matemáticos da música, Kant tende a considerá-la em algumas passagens como uma arte mais próxima do meramente agradável e de um "belo jogo das sensações". Pode-se dizer que a posição kantiana diante da música é marcada por uma certa ambivalência, havendo duas maneiras de ajuizá-

\footnotetext{
${ }^{328}$ A esse respeito, ver o comentário de Erich Adickes ao Nr. 639 das "Reflexionen zur Anthropologie" de Kant. In: KANT, I. Gesammelte Schriften Bd. XV/1 (Handschriftlicher Nachlaß). Berlin: Walter de Gruyter, 1923, p. 277-79.

${ }^{329}$ No espólio de Kant havia um exemplar da Erweiterte und verbesserte Orgel-Probe (2. Auflage, 1716), de Andreas Werckmeister. A esse respeito, ver Nachtsheim (Op. Cit., p. 14).

${ }^{330}$ KANT, KdU § 52, B 214.

${ }^{331}$ Alguns estudiosos defendem a hipótese de que o conceito kantiano de forma musical tenha sido fortemente influenciado pela teoria musical alemã da época barroca. Numa passagem de seu livro Musicae mathematicae Hodegus curiosus (2. Aufl., 1687, p. 39), A. Werckmeister afirmava, por exemplo: na música "os números e proporções dão a forma e o som é a matéria" (apud NACHSTHEIMER, S. Zu Immanuel Kants Musikästhetik, p. 12, nota 22).
} 
la: seja segundo o movimento e o atrativo do ânimo, seja a partir do ponto de vista da razão.

Para compreermos o problema da posição ocupada pela música na hierarquia das artes estabelecida por Kant, é necessário examinar primeiramente a noção de agradável [Angenehm], a saber, aquilo "que apraz aos sentidos na sensação" e que, conseqüentemente, permanece sempre como algo de subjetivo e empírico. ${ }^{332}$ Para Kant, um juízo de gosto somente pode ser considerado puro na medida em que "nenhum comprazimento meramente empírico é misturado ao fundamento de determinação do mesmo". ${ }^{333}$ Em outras palavras, a partir do momento em que um atrativo ou comoção se misturam ao meu juízo, não posso mais considerá-lo como um juízo de gosto puro. ${ }^{334}$

Assim, Kant irá afirmar que o que constitui o fundamento de toda disposição para o gosto "não é o que deleita na sensação, mas simplesmente o que apraz por sua forma". ${ }^{335}$ Donde a questão: pode a música ser considerada legitimamente como uma arte bela, capaz de promover a cultura das faculdades do ânimo? Ou deveríamos, antes, considerá-la somente como uma arte agradável, que "tem em vista simplesmente o gozo" e cujo fim é "que o prazer acompanhe as representações como simples sensações"? ?36

A partir do $\S 51$ da Crítica do Juízo, Kant esboça uma divisão das belas-artes, escolhendo como princípio para uma tal divisão "a analogia

\footnotetext{
${ }_{332}$ KANT, KdU § 3, B 7.

${ }^{333}$ KANT, KdU § 14, B 39.

${ }^{334}$ Kant afirma, por exemplo que "um simples som [...], como porventura o de um violino [...] [parece] ter por fundamento simplesmente a matéria das representações, a saber, pura e simplesmente a sensação, e por isso mereceriam ser chamados somente agradáveis" (KANT, KdU, § 14, B 39).

${ }_{335}$ KANT, KdU § 14, B 42.

${ }^{336}$ KANT, KdU § 44, B 178. Dentre as artes agradáveis, Kant inclui a música de mesa [Tafelmusik], a qual "somente como um ruído agradável [angenehmes Geräusch], deve entreter a disposição dos ânimos à alegria e, sem que alguém conceda à sua composição a mínima atenção [die mindeste Aufmerksamkeit], favorece a livre conversação entre um vizinho e outro" (KANT, KdU §44, B 178).
} 
da arte com o modo de expressão que os homens se servem no falar para se comunicarem entre si”. ${ }^{337}$ Assim, uma vez que este modo de expressão consiste "na palavra, no gesto e no som (articulação, gesticulação e modulação)", Kant divide as artes em três espécies: as elocutivas, as figurativas e a arte do jogo das sensações. ${ }^{338}$

No que diz respeito à comparação do valor estético das artes entre si, Kant considera que a posição mais elevada pertence à poesia:

[Pois] ela alarga o ânimo pelo fato de pôr em liberdade a faculdade da imaginação e oferece, dentro dos limites de um conceito dado, sob a multiplicidade ilimitada de formas possíveis concordantes com ele, aquela [forma] que conecta a apresentação daquele [conceito] com uma profusão de pensamentos [Gedankenfülle], à qual nenhuma expressão lingüística é inteiramente adequada, e portanto se eleva esteticamente às idéias.

Quanto à música, sua posição será determinada pela questão relativa a seu estatuto como arte bela ou meramente agradável.

Tomando-se em consideração o aspecto puramente matemático ${ }^{339}$ das vibrações que compõem a música, ela poderia ser representada inteiramente como uma das belas-artes. Contudo, somente as proporções matemáticas presentes nas vibrações do som não lhe bastam, pois sua "beleza formal" não passaria, então, de um momento oculto na impressão da música e que não possui a menor participação no atrativo e no

\footnotetext{
${ }^{337}$ KANT, KdU § 51, B 204.

${ }^{338}$ KANT, KdU § 51, B 205.

${ }^{339}$ Além de Werckmeister, deve-se assinalar também a influência de Rameau no que diz respeito ao aspecto matemático da música. Cf. observação de Frank e Zanetti (In: KANT, I. Schriften zur Ästhetik und Naturphilosophie. Bd. 3: Kommentar. Frankfurt a.M.: Suhrkamp, 2001 p. 1255). Como se sabe, para Rameau, a harmonia - cujas bases estariam garantidas pelas relações físicas e matemáticas originadas pela vibração e ressonância do corpo sonoro - era considerada como o princípio fundamental da música. Assim, em última instância, todo o prazer suscitado pela música também se fundamentaria na harmonia, que é "a única base da música e o princípio de seus maiores efeitos" (RAMEAU, J. P. Observations sur notre instinct pour la musique et sur son principe. Paris: Prault, 1754, p. III). Para Rameau, "mover as paixões cabe somente à harmonia. A melodia extrai sua força somente dessa fonte, da qual ela emana diretamente" (Id., ibid., p. VI).
} 
movimento do ânimo, sendo apenas "a condição indispensável (conditio sine qua non) daquela proporção das impressões". 340

Dessa forma, apesar de reconhecer o elemento formal presente em seus fundamentos matemáticos, Kant parece tender a considerar a música mais como uma arte agradável:

[...] pois embora ela fale por meras sensações sem conceitos, por conseguinte não deixa, como a poesia, sobrar algo para a reflexão [Nachdenken], contudo ela move o ânimo de modo mais variado e, embora só passageiramente, no entanto mais intimamente; mas ela é certamente mais gozo que cultura [...]. Ajuizada pela razão [Vernunft], possui valor menor que qualquer outra das belas-artes. ${ }^{341}$

Desse modo, continua Kant:

[...] se apreciarmos o valor das belas-artes segundo a cultura [Kultur] que elas alcançam para o ânimo e tomarmos como padrão de medida o alargamento das faculdades [Erweiterung der Vermögen] que na faculdade do juízo têm que concorrer para o conhecimento, então a música possui entre as artes belas o último lugar (assim como talvez o primeiro entre aquelas que são apreciadas simultaneamente segundo o seu agrado), porque ela joga simplesmente com sensações. ${ }^{342}$

Além disso, a música provoca no ouvinte apenas uma impressão transitória [transitorischem Eindrucke] e extingue-se completamente. Por fim, Kant ressalta uma certa falta de urbanidade [Mangel der Urbanität] inerente à música: pois ela "estende sua influência além do que dela se pretende (à vizinhança) e assim, como que se impõe. Por conseguinte, causa dano à liberdade de outros". ${ }^{343}$

Da mesma forma em sua Antropologia, publicada alguns anos mais tarde, Kant afirma mais uma vez a supremacia da poesia diante das demais artes:

\footnotetext{
${ }^{340}$ KANT, KdU § 53, B 220.

${ }^{341} \mathrm{KANT}, \mathrm{KdU} \S 53, \mathrm{~B} 218$.

342 KANT, KdU § 53, B 220-21.

${ }^{343}$ KANT, KdU § 53, B 221.
} 
A poesia, contudo, não obtém a vitória apenas sobre a eloqüência, mas também sobre qualquer outra das belas-artes; sobre a pintura (de que faz parte a escultura) e mesmo sobre a música. Pois esta última só é arte bela (não simplesmente agradável) porque serve de veículo à poesia. Também não há entre os poetas tantas inteligências superficiais [...] quanto entre os músicos, porque aqueles também falam ao entendimento, mas estes meramente aos sentidos. ${ }^{344}$

Como se sabe, pouco tempo após a publicação da primeira edição Crítica do Juízo (1790), já se iniciavam as discussões sobre as teses ali expostas, dentre estas a problemática posição que Kant concede à música em sua hierarquia das artes.

Em sua recensão sobre a terceira Crítica ${ }^{345}$ o filósofo Karl Leonhard Reinhold comenta que Kant tinha toda a razão ao conceder à poesia a posição mais alta entre as belas artes. E prossegue: "Os amantes da música poderão considerar como uma injusta desvalorização [ungerechte Herabwürdigung] a posição mais baixa [unterste Stelle] que o Sr. Kant concede à música [na hierarquia das artes]". No entanto ele pondera que se deve levar em conta que a música deve ser considerada de maneiras essencialmente diferentes, isto é, seja enquanto arte bela [schöne], seja como arte meramente agradável [bloß angenehme]: "Sua pretensão à beleza funda-se somente na Harmonia e Melodia". Por outro lado, com relação aos atrativos [Reiz] e comoção [Rührung] "que a música possui em tão grande medida, ela é uma arte meramente agradável, ocupa incontestavelmente o primeiro lugar na hierarquia dessas artes [i.e. das

${ }^{344}$ KANT, I. Anthropologie in pragmatischer Hinsicht. Frankfurt/M: Suhrkamp, 2000, BA 197. Trad. Bras. Antropologia de um ponto de vista pragmático. Trad. C. A. Martins. São Paulo: lluminuras, 2006, p. 144-45.

${ }_{345}$ Publicada originalmente em 1793 na Allgemeine Literatur Zeitung e reeditada em seu livro "Beiträge zur Berichtigung bisherigen Mißverständnisse in der Philosophie". 
artes agradáveis], e é o elo de ligação entre as artes belas e as agradáveis" ${ }^{346}$ Se a teoria kantiana da música encontrou um defensor de peso na figura de Reinhold, por outro lado seus críticos não tardaram a surgir.

Mesmo antes da publicação da Crítica do Juízo, Herder já se alinhava como um defensor das especificidades da música frente às demais artes. Suas posições a respeito começam a se delinear já num pequeno texto de 1785, intitulado: "Ob Malerei oder Tonkunst eine größere Wirkung gewähre? - Ein Göttergespräch". ${ }^{347}$ Trata-se de uma alegoria em que as musas da pintura e da música discutem sobre qual dessas duas artes teria o maior efeito sobre a alma humana. A musa da pintura argumenta que a primazia caberia a ela, uma vez que poderia representar todos os objetos do mundo e representar todas as paixões. A música rebate $o$ argumento dizendo que, embora a pintura consiga representar todos os objetos do mundo exterior, ela não possui tanta força [Kraft] quanto a música, pois esta, somente por meio dos sons consegue comover, de maneira imediata, todo coração sensível. Por esse motivo, a música seria a "arte das artes" [die Kunst aller Künste]. ${ }^{348}$

A pintura responde que sua arte tem o efeito mais duradouro, além de ser "mais puro, mais claro, e mais elevado" que o da música, cujo efeito seria demasiado obscuro [dunkel]. ${ }^{349}$ Esses argumentos são bastante semelhantes àqueles utilizados pelos críticos da música instrumental no início do século XVIII, principalmente de que a música

\footnotetext{
${ }^{346}$ REINHOLD, K. L. "Über das Fundament der Geschmackenlehre". In: Beiträge zur Berichtigung bisheriger Mißverständnisse der Philosophen“. Hamburg: Felix Meiner, 2004, p. 252-53.

${ }^{347}$ Numa tradução livre: "Quem proporciona um efeito maior: a pintura ou a música? Uma conversa entre os deuses". Cf. HERDER, J.G. "Ob Malerei oder Tonkunst eine größere Wirkung gewähre? - Ein Göttergespräch". In: Sämtliche Werke Bd. 15. Hg. B. Suphan. Berlin: Weidmann, 1888, p. 222-240 (Doravante: SW, seguido do volume e número de página).

${ }^{348}$ HERDER, SW 15, p. 224.

${ }^{349}$ HERDER, SW 15, p. 224.
} 
não seria um objeto estético duradouro e a falta de clareza da música instrumental pura. Tal como a famosa pergunta de Fontenelle "Sonate, que me veux-tu?", a musa da pintura pergunta: "Quem poderia dizer [com palavras] o que os sons querem significar?". Ela argumenta que a música se utilizaria de uma linguagem demasiado confusa [verworrene], ao passo que a pintura teria o efeito "mais determinado, mais claro, mais duradouro". ${ }^{350}$

A música passa então a defender sua especificidade frente à pintura e responde que é impossível exigir dela que represente figuras ou cores, pois os sons pertencem ao âmbito do invisível. Embora o efeito da música seja, de fato, mais curto e passageiro se comparado à pintura, ele é também mais íntimo e, por isso, mais forte e poderoso.

Diante dessa réplica, também a poesia resolve se manifestar:

Contudo deves admitir que sem as minhas palavras, sem o canto, a dança e coisas do gênero teus sentimentos permanecem sempre na obscuridade para os homens. Tu falas ao coração; mas quão pouco falas ao intelecto [Verstand]! E mesmo quando falas ao coração, quão freqüentemente seus sentimentos [Regung] não passam de mera comoção sensível [sinnliche Rührung]! ${ }^{351}$

No entanto, apesar dessas críticas, a poesia é obrigada a reconhecer que a música, diferentemente da pintura, não é uma arte meramente imitativa: "Tu [...] és sempre criadora, pois não possuis nenhum modelo para sua arte, nem na terra nem nos céus". ${ }^{352}$ "Justamente por isso", prossegue a música, "meu efeito é sempre novo, original e maravilhoso":

Eu sou criadora e nunca imito; eu crio os sons [...] a partir do nada, a partir do invisível, e assim eles penetram a alma, como uma linguagem mágica de um outro mundo [Zaubersprache aus einer

\footnotetext{
${ }^{350}$ HERDER, SW 15, p. 225.

${ }^{351}$ HERDER, SW 15, p. 231.

${ }^{352}$ HERDER, SW 15, p. 233.
} 
andern Welt], e ela, tomada pela torrente do canto, se esquece e se perde a si mesma. ${ }^{353}$

Novamente a poesia intervém e relembra à música o grande efeito (tão louvado pelos Antigos) que era alcançado através da união de ambas. Por fim, ela propõe: "E não voltaríamos novamente a esse antigo e grande efeito, ó minha irmã, se a tua arte se unisse à minha?". ${ }^{354}$ Entretanto, a música rejeita a oferta, e faz uma defesa de sua autonomia estética:

Lembra-te, irmã, do que tu mesma disseste: o compositor cria a partir de si mesmo, a cada vez ele precisa criar [bilden] novamente a linguagem de seus sentimentos. [...] Não quero ser totalmente servil a ti, pois tornei-me tua mestra [...]. O compositor poetiza [dichtet] quando ele toca, assim como o verdadeiro poeta canta quando poetiza. ${ }^{355}$

A disputa entre a pintura e a poesia chega ao fim graças à intervenção de Apolo: "Vós ainda discutis se o ouvido deve ser olho e se o olho deve ser ouvido? Acalmai-vos. Quanto mais diverso for o efeito de cada uma, tanto mais próprio e melhor ele será". ${ }^{356}$

Tais ponderações em defesa da especificidade estética das artes serão retomadas alguns anos mais tarde, desta vez em declarada polêmica contra a Crítica do Juízo, em seu livro "Kalligone" (1801). Em sua primeira parte, mais especificamente no capítulo intitulado "Vom Schönen und Angenehmen der Umrisse, Farben und Töne" [Do belo e do agradável nos contornos, cores e sons], Herder tece duras críticas à doutrina kantiana sobre a música. Ele nega, por exemplo, que o fundamento matemático esteja por trás do prazer proporcionado pela arte dos sons: "No que diz respeito à melodia [...] nem Rameau nem Tartini me satisfazem inteiramente; as dúvidas de Rousseau contra estes e outros

\footnotetext{
${ }^{353}$ HERDER, SW 15, p. 233.

${ }^{354}$ HERDER, SW 15, p. 236.

${ }^{355}$ HERDER, SW 15, p. 237.

${ }^{356}$ HERDER, SW 15, p. 239.
} 
teóricos parecem-me bem fundamentadas". Ao tomar o partido de Rousseau e ao negar a tradição que privilegia o fundamento matemático na música, Herder está criticando, ao mesmo tempo, a filosofia kantiana da música. Para ele "o mero cálculo das relações, a medida dos intervalos" faz muito pouco sentido como explicação do comprazimento [Wohlgefallen] que encontramos na música:

Quem calcula, quem mede, quando sente as alegrias da música da maneira mais íntima e vivaz? Ouça-se o fantasiar [i.e. a improvisação] [...] de um compositor, vendo como ele compõe com entusiasmo e gênio; ele está ocupado com outras coisas, e não com o cálculo ou a escrita de números. ${ }^{357}$

Não foram apenas autores do porte de Herder que entraram na discussão com Kant. Diversos "autores menores" expressaram suas opiniões através dos artigos e resenhas publicados nos jornais especializados em música que começavam a surgir por volta dessa época, como por exemplo, o Allgemeine musikalische Zeitung (AmZ), de Leipzig. Dentre esses trabalhos, destacaríamos um artigo publicado em 1801 na AmZ a respeito da formação da música na Alemanha no século XVIII. Utilizando-se de um vocabulário marcadamente kantiano, seu autor, Johann Triest explica a origem das belas-artes: estas teriam surgido da necessidade humana de harmonizar suas forças do ânimo [Gemüthskräfte]: "a sensibilidade entregava à imaginação um material para o livre jogo e o entendimento procurava uni-los com suas regras". ${ }^{358}$

Triest faz uma distinção entre arte pura e aplicada, distinção esta que se aplica também à música. Aqui aparece provavelmente pela primeira vez o termo "música pura", a saber: uma arte existente por si

\footnotetext{
${ }^{357}$ HERDER, J. G. Schriften zu Literatur und Philosophie 1792-1800. Hg. H. D. Irmscher. Frankfurt/M: Dt. Klassiker Verlag, 1998, p. 701.

${ }^{358}$ TRIEST, J. "Bemerkungen über die Ausbildung der Tonkunst in Deutschland im 18. Jh“. In: Allgemeine Musikalische Zeitung 3, No. 14, (01.Jan. 1801), p. 227.
} 
mesma, "elaboração de um material sensível para o livre e belo jogo da faculdade da imaginação". Por outro lado, na medida em que a música servia como um meio estético para outros fins, ela deixava de ser uma arte pura e passava a ser arte aplicada [angewandte]. ${ }^{359}$ Mais adiante ele prossegue:

Originalmente a música só possuía valor enquanto arte aplicada [angewandte Kunst], isto é, era utilizada somente como expressão de sentimentos de um sujeito e foi preciso um longo tempo antes que fosse praticada como arte pura [reine Kunst], isto é, que a melodia, harmonia, etc. fossem cultivadas como jogo belo [als schönes Spiel] mesmo sem estarem ligadas a um texto ou coisas do gênero. ${ }^{360}$

Aqui a música instrumental é considerada por Triest como música pura, isto é, "um belo jogo sonoro (formado segundo regras artísticas) que possui uma conformidade a fins, embora no todo predomine apenas uma idéia estética, indeterminada" ${ }^{361} \mathrm{e}$ - diferentemente da opinião kantiana capaz de cultivar o homem:

Se só se considerar como música genuína aquela que expõe de maneira determinada os sentimentos de um sujeito (ainda que este seja o fim original e mais elevado da música), então estariam condenadas todas as composições sem canto [...]; e todas, ou [pelo menos] a maioria das sonatas, fugas, concertos, sinfonias, etc. seriam passatempos sem finalidade [zwecklose Spielereien]. Mas não: a música deleita [vergnügt] e - com permissão dos filósofos cultiva, ainda que não de maneira tão evidente como na igreja ou no teatro. ${ }^{362}$

Além do emprego do termo música pura, um outro aspecto importante do texto de Triest está no fato dele assinalar uma "transformação significativa" que se opera no âmbito da música pura: o compositor, que até então "somente fazia cálculos enquanto escrevia" e

\footnotetext{
${ }^{359}$ TRIEST, J. "Bemerkungen über die Ausbildung der Tonkunst“, p. 227-28.

${ }^{360}$ TRIEST, J. "Bemerkungen über die Ausbildung der Tonkunst", p. 230.

${ }^{361}$ Id., ibid. Sp. 228. Ele prossegue: "Por outro lado, a materialização [Versinnlichung] musical de um sujeito (seus sentimentos e ações), na qual a poesia, a mímica, etc, ocupam o primeiro lugar, chama-se música aplicada [angewandte]".

${ }^{362}$ TRIEST, J. "Bemerkungen über die Ausbildung der Tonkunst", Sp. 228, nota.
} 
privilegiava apenas o aspecto retórico da música, passou a privilegiar seu aspecto criador e poético [poetisch]. ${ }^{363}$ Outro aspecto digno de nota é o uso da terminologia kantiana para justificar a superioridade da música pura frente à música aplicada. Para Triest, o compositor de música instrumental expressa idéias estéticas, as quais não podem ser expressas por palavras. Como exemplo prático, ele utiliza as obras para teclado de C.P.E. Bach, as quais segundo ele, ultrapassam tanto o lado mecânico ("mero cálculo") da música [ou seja, a harmonia e o contraponto]; quanto o mero prazer sensível [sinnliche Ergötzung]: "[Em suas obras] surgia uma certa idéia estética [ästhetische Idee], isto é, composta de conceito [Begriff] e sensação [Empfindung], que não pode ser expressa em palavras". ${ }^{364}$ Dessa forma, a música instrumental de C.P.E. Bach é considerada por Triest como um modelo de música instrumental pura ${ }^{365}$. Nessas obras pode-se ver que:

[...] a música pura não é mero invólucro para a [música] aplicada, ou abstraída desta, mas pode alcançar por si só grandes fins. Não lhe é preciso dar voltas como mero jogo prosaico (ou no máximo retórico) dos sentidos ou do entendimento [bloßes Sinn- oder Verstandesspiel], mas ela é capaz de se elevar a poesia [Poesie], a qual é mais pura, quanto menos ela se rebaixa, mediante palavras [...], à região do sentido vulgar. ${ }^{366}$

Ora, mas como compreender essa referência feita por Triest à "idéia estética", que "não pode ser expressa por palavras", e que se manifestaria na música pura de compositores como C.P.E. Bach? Embora não

\footnotetext{
${ }^{363}$ TRIEST, J. "Bemerkungen über die Ausbildung der Tonkunst in Deutschland im 18. Jh“. In: Allgemeine Musikalische Zeitung 3, No. 18, (28.Jan. 1801), p. 297.

${ }^{364}$ TRIEST, J. "Bemerkungen über die Ausbildung der Tonkunst in Deutschland im 18. Jh“. In: Allgemeine Musikalische Zeitung 3, No. 18, (28.Jan. 1801), p. 300.

${ }^{365}$ Ao comentar que a obra instrumental de C.P.E.Bach é muito superior à vocal, o autor o justifica: "pois ele era por demais autônomo [selbständig], original [originell] e poético [poetisch] para compor com êxito [a partir de] um texto". TRIEST, J. "Bemerkungen über die Ausbildung der Tonkunst in Deutschland im 18. Jh". In: Allgemeine Musikalische Zeitung 3, No. 18, (28.Jan. 1801), p. 302.

366 TRIEST, J. "Bemerkungen über die Ausbildung der Tonkunst in Deutschland im 18. Jh“. In: Allgemeine Musikalische Zeitung 3, No. 18, (28.Jan. 1801), p. 301.
} 
mencione a fonte, Triest está se baseando na noção de idéia estética que é apresentada no $\S 49$ da Crítica do Juízo. Intimamente relacionada ao conceito kantiano de gênio (que se mostra justamente "na exposição ou exibição de idéias estéticas"), Kant define a noção de idéia estética da seguinte forma:

Por uma idéia estética entendo [...] aquela representação da faculdade da imaginação que dá muito que pensar, sem que contudo qualquer pensamento determinado, isto é, conceito, possa ser-Ihe adequado, representação que conseqüentemente nenhuma linguagem alcança inteiramente nem pode tornar compreensível. Vêse facilmente que ela é a contrapartida (Pendant) de uma idéia da razão, que inversamente é um conceito ao qual nenhuma intuição (representação da faculdade da imaginação) pode ser adequada. ${ }^{367}$

Embora na Crítica do Juízo Kant relacione a noção de idéia estética sobretudo à arte da poesia, cabe notar que essa noção é um dos principais fundamentos filosóficos sobre o qual a valorização da música pura irá se basear a partir dessa época. Isso pode ser percebido de maneira ainda tímida e alusiva no artigo de J. Triest. De maneira mais incisiva, porém, essa idéia será retomada nos escritos do filósofo e músico C. F. Michaelis, os quais podem ser considerados como uma primeira tentativa de ir além de Kant no campo da estética musical. Partindo de pressupostos kantianos, mas aberto a influências diversas Schiller, Moritz, Herder, Jean Paul, Schelling, dentre outros - muitos textos de Michaelis constituem contribuições teóricas importantes para a autonomização estética da música instrumental, e que há até pouco tempo foram praticamente ignoradas pelos estudiosos da estética musical alemã dos séculos XVIII e XIX.

${ }^{367}$ KANT, KdU, § 49, B 192-93. 


\section{Música e autonomia: Michaelis e a noção de idéia estética}

"O músico toma a essência de sua arte de si - nem mesmo a mais leve suspeita de imitação pode atingi-lo". ${ }^{368}$

Christian Friedrich Michaelis ${ }^{369}$ (nascido em Leipzig no ano de 1770 e falecido na mesma cidade em 1834), teve aulas de instrumento, contraponto e harmonia ${ }^{370}$ na Thomasschule e na Nicolaisschule, prosseguindo estudos superiores de teologia, línguas antigas, direito e filosofia em Leipzig a partir de 1787.

Em 1792 muda-se para Jena, em cuja Universidade pôde ter aulas com Reinhold, Schütz e Schmid. Decisivas para sua formação foram as preleções sobre estética de F. Schiller, que pôde ouvir no semestre de inverno de 1792/93. ${ }^{371}$ No artigo intitulado "Rückerinnerungen über Natur und Menschen", Michaelis descreve a atmosfera das aulas de Schiller:

\footnotetext{
368 NOVALIS Fragmente und Studien 1797-93, apud FRANK, M. Einführung in die frühromantische Ästhetik. Frankfurt a.M.: Suhrkamp, 1989, p. 276.

${ }^{369}$ Uma das principais fontes para a biografia de Michaelis é o artigo publicado por F. A. Reimann no Neue Nekrolog der Deutschen. 12. Jg., 1. Teil. Weimar: Voigt, 1836, p. 557568. Cf. ainda o verbete escrito por Prantl para a Allgemeine Deutsche Biographie. Bd. 21. Leipzig: Duncker \& Humblot, 1885, p. 677-78.

370 Ao que consta, Michaelis tocava violino e piano, tendo se familiarizado com a produção instrumental dos principais compositores de sua época, como J.S. Bach, C.P.E. Bach, Haydn, Clementi, Beethoven e Mozart. Aliás, teve oportunidade de ouvir o próprio Mozart tocando órgão na Thomaskirche. Além disso, freqüentou com assiduidade os concertos da recém fundada orquestra Gewandhaus de Leipzig - sob a direção de Johann Adam Hiller (1728-1804). (Cf. Nekrolog, p. 560-561).

${ }_{371}$ As anotações de aula desse curso foram publicadas por Michaelis após a morte de Schiller e constituem o único (e importantíssimo) registro dessas preleções, já que o manuscrito original de Schiller se extraviou. Cf. Geist aus Friedrich Schillers Werken. Nebst einer Vorrede über Schillers Genie und Verdienst und zwei nach seiner Handschrift gestochenen Briefe; Bd. II, Leipzig 1806, S. 241-284: "Anhang: Noch ungedruckte Fragmente aus Schillers ästhetischen Vorlesungen vom Winterhalbjahr
} 
Diante de aproximadamente vinte ouvintes eu assistia suas aulas sobre estética. Sua fala límpida, coerente, ordenada e clara [...] conquistou-me totalmente para o pensador cheio de espírito [geistreich] que era. Com uma pequena história da estética ele fez a introdução. Depois falou da utilização e essência da arte, em sua maior parte segundo princípios kantianos. ${ }^{372}$

É por volta dessa época que Michaelis toma contato com a Crítica do Juízo de Kant, que iria influenciar profundamente seu próprio pensamento estético. Após a publicação de seu Habilitationsschrift (De voluntatis humanae libertate) torna-se, em 1793, Privatdozent em Filosofia na Universidade de Leipzig e dois anos mais tarde publica seu principal ensaio sobre estética da música: Über den Geist der Tonkunst [Sobre o espírito da música], na verdade, uma tentativa de desenvolver as teses kantianas sobre a música. ${ }^{373}$ Nos anos seguintes viaja com freqüência a Jena, onde assiste os cursos de J. G. Fichte. Trava também contato com o compositor J. F. Reichardt, a quem dedica o segundo volume de seu ensaio Über den Geist der Tonkunst (publicado em 1800). Nos anos seguintes ele publicaria comentários sobre algumas das principais obras

1792-93“. Há uma tradução brasileira desse texto: SCHILLER, F. Fragmentos das preleções sobre estética do semestre de inverno de 1792-93. Trad. R. Barbosa. B. Horizonte: Ed. UFMG, 2004.

${ }^{372}$ Monatsschrift für Deutsche III, 2 (1802, V. Heft, Mai), p. 13

${ }^{373}$ Michaelis chegou a enviar um exemplar de seu livro para Schiller, como comprova a carta datada de 22.06.1795 (Cf. Brief Nr. 232. Schillers Werke, Nationalausgabe Bd 35. Weimar: Böhlau, 1964, p. 227). Infelizmente não há registro da resposta de Schiller. 
de Kant $^{374}$ e Fichte $^{375}$; bem como traduções ${ }^{376}$ e diversos artigos em jornais de música. ${ }^{377}$

No artigo "Sobre a posição da música entre as belas-artes" [Ueber den Rang der Tonkunst unter den schönen Künsten] ${ }^{378}$ publicado em 1799, Michaelis mostra-se ainda totalmente dependente de Kant: trata-se, aqui, de uma espécie de texto de popularização, parafraseando o conteúdo dos $\S 51$ a 53 da Crítica do Juízo, acerca da divisão e comparação do valor das belas-artes entre si. Neste artigo, seguindo de perto as observações de Kant, Michaelis considera que a Poesia e a Eloqüência dirigem-se primeiramente ao entendimento [Verstand], por meio das palavras e conceitos [Begriffe] que utiliza; as Artes Plásticas, por sua vez, dirigem-se primeiramente ao sentido da visão. Seu conteúdo [Inhalt] consiste em intuições externas e, por isso sua ligação com a imaginação [Einbildungskraft]. Por fim, a Música, por meio do sentido da audição, do sentido interno, dirige-se primeiramente à faculdade dos sentimentos [Gefühlvermögen]. ${ }^{379}$ Cabe notar que também aqui ele adere

\footnotetext{
374 "Entwurf der Aesthetik, als Leitfaden bei akademischen Vorlesungen über Kants Kritik der Urteilskraft”, 1796; "Kritik des teleologischen Beurteilungsvermögens“, 1798; „Ueber die Wichtigkeit der Untersuchungen der Kritik der praktischen Vernunft", 1800

375 "Philosophische Rechtslehre, zur Erläuterung über Fichtes Grundlage des Naturrechts", 1797-99; "Systhematischer Auszug aus Fichtes Grundlage der gesammten Wissenschaftslehre", 1798.

${ }^{376}$ Ao que parece, Michaelis dominava diversas línguas como o latim, francês e italiano. Sua grande predileção era o idioma inglês do qual traduziu e comentou diversos livros, entre eles a "História da Música" de Thomas Busbys. Cf. Nekrolog, p. 562-63. Para uma relação das obras traduzidas por ele, cf. p. 567-68.

${ }^{377}$ Publicou artigos sobre estética e teoria da música para a Allgemeine musikalische Zeitung de Leipzig, para a Berlinische musikalische Zeitung, Eunomia, Cäcilia e mais tarde para a Allgemeine musikalische Zeitung mit besonderer Rücksicht auf den Österreichischen Kaiserstaat, entre outras.

${ }_{378}$ Originalmente publicado na AmZ 2, Nr. 10 (04.12.1799), p. 183-86.

${ }^{379}$ No artigo "Sobre a pintura musical" [Ueber die musikalische Malerei] publicado em 1800, ele escreve: "No caso da música, na medida em que ela atua sozinha, abstraímos
} 
completamente à teoria kantiana, segundo a qual a música somente poderia ter uma alta posição na hierarquia das artes "em se tratando do atrativo [Reiz] e movimento do ânimo" que ela proporciona, mais do que as demais artes. ${ }^{380}$

Feita essa divisão de acordo com os meios que cada arte emprega, e conforme a faculdade do ânimo a que se dirigem, cabe determinar agora o critério para comparação entre as diversas artes, o que permitirá determinar o que torna uma arte mais "digna" do que as demais. Esse critério é a maior ou menor predisposição [Empfänglichkeit] de cada arte para a pura forma da beleza, sua capacidade de determinação na expressão do belo, do sublime e do moral, ou seja, quanto maior a sua capacidade de "cultivar" um indivíduo [je kultivierender sie ist], tanto maior o seu valor. Desse modo, mais uma vez ele seguirá a divisão hierárquica proposta por $\mathrm{Kant}^{381}$, atribuindo à poesia [Dichtkunst] a primeira posição entre as artes. Logo em seguida estão as artes plásticas e por último, a música. ${ }^{382}$

Utilizando-se de expressões muito similares às de Kant, Michaelis justifica a posição da música através do seguinte argumento: apesar da música ser a arte que proporciona o maior gozo [den grössten Genuss], ela também é a que menos proporciona cultura [Kultur], pois lida com meras sensações [blossen Empfindungen], que conduzem apenas a idéias indeterminadas de afetos. Ele prossegue:

de todo o visível [von allem sichtbaren] e de tudo exterior a nós; ela volta totalmente a nossa atenção para o nosso interior [Inneres], a saber, para as representações da imaginaçãao e as mudanças de nossos estados de ânimo [Gemüthzustandes], causadas por suas modulações" (MICHAELIS, Über den Geist der Tonkunst und andere Schriften. Hg. L. Schmidt. Chemnitz: Gudrun Schröder Verlag, 1997, p. 153 - doravante citado pela sigla GT).

${ }^{380}$ Cf. KANT, KdU § 53, B 218.

${ }^{381}$ Cf. KANT, KdU§ 53, B 215: "Entre todas [as artes] a poesia é aquela que possui a posição mais elevada".

${ }_{382}$ Ao afimar que último lugar na hierarquia das artes cabe à música, Michaelis assume mais uma vez o ponto de vista kantiano, para o qual a música seria, "contudo, mais gozo do que cultura" [mehr Genuß als Kultur]" (KANT, KdU, § 53, B 218). 
Também com referência à determinação e pureza da bela exposição [schöne Darstellung], ela vem após as demais artes, pois não pode impedir a mistura de encantos dos sentidos agradáveis ou desagradáveis [angenehmer oder unangenehmer Sinnenreize] tanto quanto as outras artes. ${ }^{383}$

No artigo "Algumas idéias sobre a natureza estética da música" [Einige Ideen über die ästhetische Natur der Tonkunst] ${ }^{384}$, publicado em 1801, percebemos já algumas mudanças em comparação ao artigo anterior. Aqui ele enfatiza a música como arte do sentido interno e da imaginação. Estando ligada à forma do sentido interno (a saber, o tempo) e estando completamente separada da forma do sentido externo, (ou seja, o espaço), a música pode representar meramente as mudanças no tempo, "com o espaço e seu conteúdo ela não tem nada a ver [...]. Porém as meras mudanças no tempo só podem ser sensações internas [innere Empfindungen], as quais são apreendidas, agrupadas e expostas por meio da imaginação [Einbildungskraft]". ${ }^{385}$ A música, como arte dos sons, não descreve nada que seja externo, nada que seja extenso ou espacial, mas "somente o interior [das Innere], a mera determinação do tempo" ${ }^{386}$

Temos aqui, portanto, uma valorização da música como arte da interioridade, como "arte do coração". Por voltar-se à interioridade, ela será caracterizada como a arte diametralmente oposta às artes plásticas, pois é arte do tempo, enquanto estas são artes do espaço. Justamente por ser uma arte da interioridade e do tempo, a música vai ser considerada como uma linguagem imediata dos afetos:

A sucessão das sensações internas, na medida em que se manifestam por meio de sons, constitui o material [Stoff], [...] em cuja formação [Bildung] e exposição [Darstellung] a música se exterioriza. [...] As sensações internas denominam-se Afetos [Affekte]. [...] Por

\footnotetext{
${ }^{383}$ MICHAELIS, GT, p. 148.

${ }^{384}$ Originalmente publicado em Eunomia 1, Nr. 1 (Março de 1801), p. 254-260.

385 MICHAELIS, GT, p. 175.

${ }^{386}$ MICHAELIS, GT, p. 175.
} 
isso a música se dá a conhecer como linguagem imediata dos afetos". ${ }^{387}$

Devido à característica da interioridade, Michaelis pode argumentar em favor de uma certa valorização da música, porém ainda não como arte autônoma, mas devido a uma certa analogia que ele percebe entre música e poesia: "pois como a música nada tem a ver com o espaço [...] ela se aproxima muito mais da poesia, do que a escultura e a pintura, e lida mais intimamente e de maneira imediata com a parte mais espiritual e interna do homem, do que aquelas artes que se misturam ao mundo corpóreo". 388

O alto valor que a poesia possui no interior das tradicionais hierarquias das artes tem a ver com o fato de utilizar-se de palavras e, portanto, de "elevar" a alma a conceitos [Begriffen]; enquanto a música, por sua vez, tem como esfera "o coração humano, com seus sentimentos [Empfindungen] e a imaginação [Einbildungskraft], em sua ocupação com os afetos". ${ }^{389}$ Assim, o valor maior da música estaria em sua capacidade de comover de maneira imediata, diferentemente das demais artes, que para tanto necessitam de mediações.

Como arte do sentido interno [innern Sinn], da imaginação, do tempo, avessa a toda espacialidade, a música é, por excelência, a arte da interioridade, uma vez que lida especialmente com 0 invisível [Unsichtbar]:

O poeta interpreta e reúne em conceitos os grandes e belos sentimentos [...] com os quais ele pretende nos dar prazer [ergötzen], e procura comunicá-los [...] por meio de palavras. [...] Mediante 0 entendimento [Verstand] ele excita nossa imaginação, e através disso ele nos suscita sentimentos e afetos. O poeta nos mantém em conexão com o mundo visível, pois seus conceitos estão sempre em

\footnotetext{
${ }^{387}$ MICHAELIS, GT, p. 175.

${ }^{388}$ MICHAELIS, GT, p. 175.

${ }^{389}$ MICHAELIS, GT, p. 176.
} 
íntima relação com este; o compositor nos separa do mesmo, e nos entretém com o invisível [Unsichtbaren]. ${ }^{390}$

No que diz respeito à questão: se a música seria meramente uma arte agradável ou se poderia ser, com direito, contada entre as artes belas, Michaelis irá lidar com a concepção de que a música, para ser considerada bela, deve agradar por si mesma. Se por um lado, a música pode ser considerada uma arte agradável na medida em que seu material pode causar prazer mesmo sem ser trabalhado (ou seja, é possível obter prazer mediante o puro som); por outro lado, ela só pode ser considerada uma arte bela por meio da composição musical. É graças à composição que $o$ artista ordena e depura a massa sonora, formando um todo [Ganze] adequado à imaginação. ${ }^{391}$

Ele continua: "A beleza da música baseia-se na Melodia e Harmonia. A melodia expressa o jogo dos sentimentos [Empfindungen] [...], forma a multiplicidade [das Mannigfaltige], sem a qual a beleza não é possível". Mas essa multiplicidade não pode se perder na ausência de regras, e deve, portanto, ser determinada para que haja beleza. Essa determinação resulta do compasso, do ritmo e da harmonia. Assim, para que a melodia se torne um todo belo [schönes Ganzes], ela necessita de uma forma harmônica e rítmica. Tal forma bela, segundo Michaelis, "agrada por si" [gefällt für sich], por meio de uma proporção livre, da simetria e depende de uma conformidade a leis livre [freie Gesetzmäßigkeit]. ${ }^{392}$

No artigo "Suplemento às idéias sobre a natureza estética da música" [Nachtrag zu den Ideen über die ästhetische Natur der Musik] $]^{393}$, Michaelis - utilizando-se das ferramentas teóricas proporcionadas pela filosofia kantiana - irá construir uma argumentação no sentido de se

\footnotetext{
${ }^{390}$ MICHAELIS, GT, p. 176.

${ }^{391}$ MICHAELIS, GT, p. 177-78.

392 MICHAELIS, GT, p. 178.

${ }^{393}$ Originalmente publicado em Eunomia 1, Nr. 1 (Abril de 1801), p. 343-348.
} 
considerar a indeterminação própria à música, a qual havia sido durante séculos a causa das censuras que se voltavam contra ela, como algo positivo. Essa indeterminação característica da música pura passa então a ser vista como algo que favorece a liberdade de fantasia do ouvinte. Elas são, de certa forma, algo análogo às idéias estéticas ${ }^{394}$ do poeta. $\mathrm{Na}$ medida em que a música é capaz de fornecer um campo infinito de pensamentos, ela possui também algo de ideal [etwas Idealisches] "algo que liberta e dá asas à imaginação, e a eleva acima das limitações da realidade". ${ }^{395}$

No artigo "Mais algumas observações sobre a posição da música dentre as belas-artes" [Noch einige Bemerkungen über den Rang der Tonkunst unter den schönen Künsten] $]^{396}$ Michaelis irá combater a opinião kantiana segundo a qual a música seria, dentre as belas-artes, aquela que proporciona menos cultura [Kultur]. Para Michaelis, a música é capaz de cultivar o espírito, na medida em que ela nos separa do mundo corpóreo e nos entretém com formas invisíveis [unsichtbaren Formen]. A música não é meramente uma arte agradável aos sentidos, não é um mero prazer sensível, mas uma arte que atua de maneira espiritual [geistige Art], cuja esfera própria é o âmbito do invisível [Unsichtbaren] e na qual a faculdade da imaginação possui um papel decisivo:

As sensações com as quais ela lida, não são sua [finalidade] última; seu fim não é uma mera excitação dos nervos, assim como não é a

\footnotetext{
${ }^{394}$ No $\S 49$ da Crítica do Juízo, Kant define a noção de idéia estética, a saber: "por uma idéia estética entendo [...] aquela representação da faculdade da imaginação que dá muito que pensar, sem que contudo qualquer pensamento determinado, isto é, conceito, possa ser-lhe adequado, representação que conseqüentemente nenhuma linguagem alcança inteiramente nem pode tornar compreensível" (KANT, KdU, B192-3). Muito embora Kant atribua à música um lugar pouco lisonjeiro ao comparar o valor estético das belas-artes entre si (cf. por exemplo o $\$ 53$ da Crítica do Juízo), deve-se notar que esse conceito de idéia estética será um dos principais fundamentos filosóficos sobre alguns autores pós-kantianos (Michaelis e Triest, por exemplo) utilizarão para basear seus argumentos em favor da valorização da música pura a partir dessa época.

${ }^{395}$ MICHAELIS, GT, p. 180

${ }^{396}$ Publicado originalmente na AmZ 6, Nr. 46 (15.08.1804), p. 765-775.
} 
cor das pinturas ou o brilho do mármore das colunas que constituem o efeito último dessas artes; é a imaginação [Einbildungskraft] que compõe um todo belo e sublime [...] a partir das sensações auditivas; e na fruição [Genuß] obtida a partir daí, [é a imaginação] que nos eleva silenciosamente acima das necessidades corpóreas e dos estímulos sensoriais. Nós nos perdemos na contemplação espiritual do elemento objetivo de uma bela composição musical, tanto quanto na sublimidade de uma ode de Klopstock; mas com a diferença que aqui [na ode] a nossa atividade é mais determinada, através de conceitos, enquanto lá [na música], a liberdade permanece, para acrescentar um conteúdo [Inhalt] para a mera forma da sensação. ${ }^{397}$

Outro aspecto a ser notado neste artigo é a influência de Schelling especialmente sua definição da belaza como exposição do infinito no finito - que já começava a se impor nos meios musicais:

A música deve ser considerada, talvez, como a mais livre dentre as demais artes, porque ela se apodera de nossa imaginação da maneira mais imediata, e pode preenchê-la com formas belas e sublimes, sem estar limitada ao âmbito dos conceitos do entendimento ou das intuições da efetividade comum. Nela, o individual e o ideal parecem unir-se da maneira mais fácil e íntima, nela se expressa talvez da maneira mais viva (como dizem os estetas modernos) a infinito através do finito [das Unendliche durch das Endliche]. ${ }^{398}$

Ao longo dos anos Michaelis irá desenvolver e tornar mais precisa sua própria posição, que pode ser considerada como uma tentativa de síntese de toda a discussão estética da época acerca do valor da música.

É talvez num artigo de 1808, intitulado "Sobre o aspecto ideal da música" [Ueber das Idealische der Tonkunst] ${ }^{399}$, que suas idéias aparecem de maneira mais incisiva. Antes de mais nada, é preciso perguntar: como entender essa definição da música enquanto uma arte ideal [idealisch]? É bastante provável que Michaelis estivesse empregando esse conceito no mesmo sentido definido por $A$. W. Schlegel, quando ele afirma: "Pode-se chamar [...] uma obra de arte de

\footnotetext{
${ }^{397}$ MICHAELIS, GT, p. 191.

${ }^{398}$ MICHAELIS, GT, p. 192.

${ }^{399}$ Publicado originalmente na AmZ 10, Nr. 29 (13.04.1808), p. 448-452.
} 
ideal [idealisch], quando nela matéria e forma [Stoff und Form], espírito e letra penetraram-se mutuamente até a completa indistinguibilidade". 400

Partindo de uma crítica ao princípio de imitação, Michaelis define a música como a "mais ideal e mais original" dentre as artes, uma vez que ela, por sua própria essência, "não consiste numa mera imitação [Nachahmung] da natureza". Sua finalidade não consiste numa mera imitação do mundo exterior, mas antes, ela produz como que por magia "um mundo totalmente próprio", de modo que é em vão que procuraríamos na realidade um suposto original, que the pudesse servir de modelo. Diferentemente das demais artes, a música não possui um "original" exterior a si mesma e seu encanto resulta de uma criação proveniente do próprio mundo interior do artista e não possui "nem forma [Form], nem matéria [Stoff], nem modelo [Urbild]" no mundo exterior. ${ }^{401}$

Michaelis coloca a música numa posição tão elevada em comparação às demais artes belas, que ele chega mesmo a afirmar que ela expõe [darstellt] de maneira pura, "o espírito [Geist] da arte, em sua liberdade e singularidade". A faculdade da imaginação, que tão elevada posição ocupa no contexto da filosofia crítica kantiana, aparece também como fundamental para a arte dos sons. Ele escreve: "A imaginação poética, criadora, revela integralmente a sua força na arte dos sons". $O$ valor da música é intrínseco a si própria e não reside numa representação ou significado de outra coisa que não seja ela mesma: "As obras musicais

\footnotetext{
$\overline{400}$ SCHLEGEL, A. W. Die Kunstlehre, p. 72. Note-se que esse aspecto da indivisibilidade entre forma e conteúdo na música foi ressaltado também por Goethe, numa Reflexão do ano de 1829: "A dignidade da arte aparece talvez na música de um modo o mais eminente, porque ela não tem matéria alguma que tivesse de ser descontada (da forma). Ela é completamente forma e conteúdo, e eleva e enobrece tudo quanto exprime" (Cf. GOETHE, J. W. Escritos sobre arte. Trad. M. A. Werle. S. Paulo: Humanitas, 2005, p. 266-67). Também o esteta e crítico musical vienense irá defender que forma e conteúdo são indissociáveis em música: "A música consiste em [...] formas sonoras [Tonformen], as quais não têm nenhum outro conteúdo [Inhalt] além de si mesmas" (HANSLICK, E. Vom musikalisch-Schönen, p. 96. Trad. Port. Do Belo Musical, p, 100).

${ }^{401}$ MICHAELIS, GT, p. 264
} 
consumadas [vollendete] possuem seu valor não meramente porque elas representam ou significam algo outro, mas [possuem valor] nelas mesmas, em sua própria e incomparável essência [Wesen]". ${ }^{402}$ É por conta dessa radical autonomia e liberdade que a música poderá ser tomada como modelo para todas as demais artes: ela é a única totalmente autônoma, que nada imita e que dita a si mesma suas próprias leis.

A música ocupa uma posição de destaque também quanto ao seu material; pois ela não se origina da natureza bruta, mas é um produto ideal [idealisch] da faculdade poética do artista criador. Enquanto o pintor ou escultor sempre apontam para um objeto natural, e nesse sentido, são dependentes de um material proveniente da realidade exterior, 0 compositor "não encontra na natureza nenhum todo musical [musikalisches Ganzes] diante de si”, o qual só precisasse ser retrabalhado ou reelaborado. Pelo contrário, "ele cria a verdadeira música meramente a partir de seu interior [aus seinem Innern]": 403

Suas melodias e harmonias não são emprestadas da natureza bruta, não são como que tomadas de empréstimo das criaturas cantantes [...], mas são invenção originária [ursprünglich] do homem pleno de sentimentos, dotado de imaginação e sentido para proporção [Ebenmaß] e harmonia [Wohlklang], são produtos ideais de uma faculdade poética [Dichtungsvermögens] ligada a uma organização propícia. ${ }^{404}$

A mudança radical que se opera, não apenas no pensamento de Michaelis, mas que vai aos poucos se impondo na estética musical como

\footnotetext{
402 MICHAELIS, GT, p. 264-65.

${ }^{403}$ Alguns anos mais adiante o escritor e compositor E.T.A. Hoffmann irá defender um ponto de vista semelhante, no texto "Ahnungen aus dem Reiche der Töne" (1814): "Nosso reino não é deste mundo - dizem os músicos - pois onde encontramos na natureza, tal como [o fazem] o pintor e o escultor, o protótipo de nossa arte? O som habita em toda parte, mas os sons, isto é, as melodias que falam a linguagem elevada do reino dos espíritos [die höhere Sprache des Geisterreichs], habitam apenas no peito humano" (HOFFMANN, Schriften zur Musik, p. 609-10).

${ }^{404}$ MICHAELIS, GT, p. 264-65.
} 
um todo, pode ser verificada mediante a comparação entre música e poesia. Se a poesia, em última instância, se refere sempre a objetos do conhecimento ou idéias da razão, se a linguagem que ela utiliza já está pronta; a música, por sua vez precisa sempre constituir a sua própria linguagem. A música não recebe a sua lei de nenhuma linguagem existente, mas "ela se dá sua própria lei" [sie ist ihre eigene Gesetzgeberin], ou seja, ela é autônoma, na medida em que "flui do mais íntimo da humanidade e só se submete às leis eternas da harmonia". ${ }^{405}$ Como ela não tem seu modelo na natureza, tampouco esta pode servir como pedra de toque para se avaliar o seu grau de perfeição (tal como ocorre com o pintor ou escultor, cujas obras tanto mais perfeitas são, quanto mais se aproximam daquilo que é imitado). Diferentemente da poesia, a música não se refere a objetos determinados do conhecimento, nem de maneira imediata a nenhuma idéia da razão, mas ela pode expressar sentimentos [Gefühle ausdrücken] ${ }^{406}$, os quais "despertam em nós certos objetos e idéias" ${ }^{407}$ Assim, se ela não se refere a objetos e idéias da razão de maneira imediata, como a poesia, ela pode referir-se a isso de maneira imediata, pode aludir simbolicamente [sinnbildlich] "o que nosso espírito intui ou pensa". 408

Michaelis encerra o artigo com uma significativa citação do compositor J. F. Reichardt ${ }^{409}$, na qual estão presentes alguns elementos característicos do Romantismo na música, especialmente no que diz respeito a dois aspectos principais: primeiramente, a música passa a se situar numa posição mais elevada do que a poesia (o próprio efeito da ${ }^{405}$ MICHAELIS, GT, p. 265.

${ }^{406}$ Aqui vemos uma diferença fundamental se compararmos Michaelis e Hanslick, por exemplo: apesar de Michaelis também se referir à música como arte autônoma, ele ainda está preso à concepção da música como expressão de sentimentos.

${ }^{407}$ MICHAELIS, GT, p. 265-66.

${ }^{408}$ MICHAELIS, GT, p. 266.

${ }^{409}$ Trata-se de uma observação que Reichardt havia acrescentado a um artigo intitulado "Vermischte Bemerkungen über Musik", publicado alguns anos antes por Michaelis no Berlinische musikalische Zeitung, 1. Jg., Nr. 4 (1805), p. 13. 
poesia é alcançado, em última instância, pelo ritmo, logo, ele é dependente de uma certa origem musical); em segundo lugar, ela passa a ser vista como uma linguagem capaz de exprimir o inefável, isto é, capaz de expressar aquilo que não se poderia dizer com a linguagem das palavras:

Onde as palavras não mais conseguem, não são mais suficientes, os sons, as harmonias expressam o inefável [das Unaussprechlich] e elevam o entusiasta [Begeisterten] muito acima de si mesmo. A construção dos versos e o ritmo poético mais perfeito recebem, eles mesmos, a sua mais elevada força e efeito somente mediante o ritmo musical que a ele se agrega. ${ }^{410}$

Retomando a questão da recepção dos escritos kantianos sobre a música, vale ressaltar que Kant não tinha em vista constituir um sistema das artes em sua Crítica do Juízo, e "muito menos uma teoria filosófica especial da música ou de outra arte. As estéticas especiais estavam fora do âmbito de problemas que Kant havia se colocado". ${ }^{411}$ Mesmo o trecho referente à divisão das artes entre si não pretendia ser uma teoria completa e acabada das artes, mas sim apenas um "esboço", como o próprio Kant ressalta numa nota de rodapé, à qual, provavelmente, poucos de seus críticos prestaram atenção. ${ }^{412} \mathrm{Nela}$, Kant alerta:

${ }^{410}$ Apud MICHAELIS, GT, p. 266. É interessante notar uma certa semelhança entre essa
formulação de Reichardt e um artigo de Forkel, publicado em 1778 na Musikalisch-
Kritische Bibliothek. Ali (Op. Cit., p. 66-67), Forkel afirmava que "onde as outras
linguagens não são mais suficientes, onde acaba sua capacidade de expressão" a
música começa a ser "uma linguagem da gradação infinita dos sentimentos". No entanto,
a diferença entre os dois autores é clara: Forkel está ainda ligado à concepção de
música como expressão dos sentimentos, enquanto a formulação de Reichardt está
ligada às concepções românticas da música como linguagem do inefável.
${ }_{411}$ NACHTSHEIM, S. Zu Immanuel Kants Musikästhetik, p. 15.
${ }^{412}$ Talvez isso se deva, em parte, à possibilidade de que muitos desses autores possam
ter tomado contato com as observações de Kant sobre a música apenas em segunda
mão, a partir dos inúmeros excertos publicados nos jornais especializados da época, 
O leitor não ajuizará este esboço [Entwurf] de uma possível divisão das belas-artes como uma propositada teoria. Trata-se apenas de uma das muitas tentativas [Versuchen] que ainda se podem e devem empreender. ${ }^{413}$

Porém, como se viu, as passagens referentes à música tanto na Crítica do Juízo como na Antropologia não tardaram a provocar polêmicas, suscitando objeções e posições contrárias. Entretanto, mais do que nas afirmações do próprio Kant acerca da arte dos sons, a chave para a compreensão da valorização da música pelos autores póskantianos parece estar, sobretudo, na recepção dos conceitos kantianos de gênio e de idéia estética. Foi, em grande medida, graças ao conceito de idéia estética, que a indeterminação conceitual da música puramente instrumental passou a ser considerada não mais como um vazio de conteúdo ou como um mero ruído agradável aos sentidos, mas sim, como um conteúdo inexponível em conceitos e que ultrapassa a mera linguagem das palavras.

Além de Kant, também a filosofia de Schelling desempenhou um papel importante na estética musical do início do século XIX. Com efeito, não tardou muito para que alguns autores procurassem aproximar a "idéia estética" kantiana com o "infinito" de Schelling: se Kant havia definido a beleza como sendo a expressão de idéias estéticas ${ }^{414}$, a definição da beleza dada por Schelling como sendo "o infinito exposto finitamente"415 logo passou a ser aplicada à estética da música. ${ }^{416}$ Já em 1800 (ou seja,

como, por exemplo, no Musikalisches Kunstmagazin (2. Bd., 7. Stück, 1791, p. 65ss.) e no Allgemeine musikalische Zeitung ("Aus Kants Anthropologie", In: AmZ 2, Nr. 1, 02.10.1799, p. 23-25).

${ }^{413}$ KANT, KdU § 51, B 205.

${ }_{414}^{4}$ KANT, KdU § 51, B 204.

${ }^{415}$ SCHELLING, Ausgewählte Schriften I, p. I/3, 620.

${ }^{416}$ Num artigo publicado alguns anos mais tarde na AmZ, G. W. Fink escreve: "Mas, nestas páginas, onde se falou expressamente dos juízos de Kant sobre a música, freqüentemente [em defesa de uma posição] contrária à dele. - Quando, posteriormente, a filosofia de Schelling começou a intervir na Alemanha, [este jornal] passou a orientar- 
no mesmo ano de publicação do Sistema do (dealismo Transcendental), a AmZ publicou uma recensão do livro Phantasien über die Kunst, de Wackenroder e Tieck, na qual se faz referência à "união do infinito e do finito na arte" e se afirma que a essência da arte é a "exposição sensível do supra-sensível" [Sinnliche Darstellung des Übersinnlichen], isto é, "o sensível, no qual o supra-sensível se revela". ${ }^{417}$

O exame desses textos publicados nos principais periódicos musicais de língua alemã na primeira década do século XIX revelou que a discussão estética levada a cabo ali estava fortemente enraizada nas questões filosóficas da época. Como se procurou indicar, as referências a Kant e Schelling ${ }^{418}$ tornam-se bastante freqüentes durante esse período, de modo que é neste contexto que se deve ler as críticas e análises musicais publicadas por Hoffmann a partir de 1809 na AmZ - e em especial, a sua recensão acerca da Quinta Sinfonia de Beethoven.

se por ela, e não segundo a [filosofia] de Kant" (cf. FINK, G. W. "Antwort auf einige Punkte der Recension der Berliner allgemeine musikalische Zeitung, von H. Dorn, im 31. Heft der Cäcilia". In: AmZ 30, Nr. 36 (03.09.1828), p. 587).

417 [ROCHLITZ, F.] "Recension: Phantasien über die Kunst". In: AmZ 2, Nr. 23 (05.03.1800), p. 401. A respeito da autoria deste artigo, cf. LAFITE, M. Musikästhetik im frühen 19. Jahrhundert. Dissertation zur Erlangung des Doktorgrades an der Universität Wien, 1974, p. 37.

${ }^{418}$ Além dos textos de Michaelis, poderíamos citar também os "Musikalische Fragmente" publicados por Franz Horn na AmZ em 1802. Ali, ele afirma: "A beleza nada mais é que [...] o sentimento de infinitude na finitude [...]. A beleza é a totalidade no uno [Alles in Einem]" (AmZ 4, Nr. 25, 17.03,1802, p. 404); "[Na música], o infinito deve ser exposto no finito" (AmZ 4, Nr. 26, 24.03.1802, p. 420); "[A música é] a pura inapreensibilidade, mas justamente por isso ela também admite a intuição intelectual pura [reine, intellektuelle Anschauung]" (Id., ibid., p. 419); "[Através da música] o infinito manifesta-se para a fantasia, já que ele não pode aparecer enquanto tal” (Id., ibid., p. 422). 


\title{
VI. CRÍTICA MUSICAL ENQUANTO TEORIA ESTÉTICA
}

\begin{abstract}
"As teorias estéticas sobre a música e, antes de mais nada, os programas estéticos (isto é, as exigências expressas acerca da música) são impensáveis sem a análise. [...] Toda crítica que seja dotada de algum valor é fundada na análise. $\mathrm{Na}$ medida em que não o é, [a crítica] se detém na impressão não-obrigatória [unverbindlich] e poderia merecer, já por causa disso, ser vista com a mais alta desconfiança". 419
\end{abstract}

A crítica musical publicada em jornais especializados é um fenômeno que só começou a se estabelecer firmemente na Alemanha no final do século XVIII e início do século XIX. De acordo com Ulrich Tadday, até então não havia jornais que se dedicassem exclusivamente a temas culturais e, além disso, a música desempenhava um papel apenas secundário - para não dizer: quase inexistente - nos demais jornais e gazetas da época. ${ }^{420}$ Essa situação começou a mudar a partir de 1798 , com a fundação do Allgemeine musikalische Zeitung (AmZ) na cidade de

${ }^{419}$ ADORNO, T. W. "Zum Problem der musikalischen Analyse". In: Frankfurter Adorno Blätter Bd. 7. München: edition text+kritik, 2001, p. 78-79.

${ }^{420}$ TADDAY, U. Die Anfänge des Musikfeuilletons: der kommunikative Gebrauchswert musikalischer Bildung in Deutschland um 1800. Stuttgart: Metzler, 1993. Além do estudo de Tadday, uma referência importante a esse respeito é: LAFITE, M. Musikästhetik im frühen 19. Jahrhundert. Dissertation zur Erlangung des Doktorgrades an der Universität Wien, 1974. 
Leipzig, que em poucos anos tornou-se o mais influente jornal musical de língua alemã, transformando-se num modelo para as publicações que viriam a ser fundadas posteriormente, como o Berlinische musikalische Zeitung (fundado em 1805, por J. F. Reichardt) e o Berliner allgemeine musikalische Zeitung (fundado por A. B. Marx, em 1824), entre outros.

Em 12 de janeiro de 1809, Hoffmann envia ao editor Friedrich Rochlitz, aquela que viria a ser sua primeira obra literária importante a ser publicada e também sua primeira contribuição para a AmZ. Trata-se do conto "Ritter Gluck", que mais tarde seria incorporado às suas Fantasiestücke in Callots Manier (1814). Na carta que acompanhava o conto, Hoffmann dizia:

\begin{abstract}
Atrevo-me a enviar-Ihe um pequeno ensaio [...], e pergunto-lhe se ele poderia porventura ser aceito pela AmZ. [...] Talvez eu pudesse [...] ocasionalmente escrever ensaios e também recensões de pequenas obras. Ficaria muito grato se o senhor tivesse a bondade de se interessar por esses trabalhos [...]. ${ }^{421}$
\end{abstract}

A oferta foi aceita pelo editor, que publicou o conto em 15 de fevereiro daquele mesmo ano (AmZ, 11. Jg, Nr. 20) e convidou Hoffmann para trabalhar como colaborador daquele jornal. A primeira recensão de Hoffmann para o AmZ, publicada em 17 de abril de 1809, foi a respeito de uma Sinfonia em Ré Maior de Friedrich Witt. Nessa recensão, Hoffmann chama a atenção do leitor para o enorme progresso alcançado pela música instrumental de sua época que, impulsionada pelas obras geniais de Haydn e Mozart, tornou-se o gênero supremo [das Höchste] da música instrumental, "por assim dizer, a ópera dos instrumentos". ${ }^{422}$

${ }^{421}$ Cf. HOFFMANN, E. T. A. Briefe und Tagebücher I. Hg. W. Harich. Weimar: Erich Lichtenstein, 1924, p. 269.

${ }^{422}$ HOFFMANN, E. T. A. Schriften zur Musik, p. 19. 
Entre 1809 e 1815, Hoffmann publicou 29 recensões na $A m Z^{423}$, sendo cinco delas sobre obras de Beethoven. ${ }^{424}$ Dentre elas, a mais significativa é, sem dúvida, a célebre recensão sobre a Quinta Sinfonia, de Beethoven. Foi somente em maio de 1810, cerca de dez meses após receber a partitura da sinfonia, que Hoffmann enviou a recensão para a redação da AmZ. ${ }^{425}$ Outros autores já haviam escrito críticas musicais sobre obras de Beethoven para a $A m Z^{426}$, às quais Hoffmann se refere de maneira implícita. A organização formal do texto de Hoffmann não diferere muito do padrão imposto pelo editor do jornal aos seus colaboradores, consistindo basicamente numa introdução de caráter geral, uma parte central analítica e considerações finais. No entanto, as dimensões da recensão da Quinta Sinfonia ultrapassam bastante os limites usuais para a época. Mas Hoffmann se destaca dos demais críticos especialmente pelas observações estéticas feitas na primeira e na última parte, pela profundidade e detalhamento da análise musical levada a cabo na parte central do texto e, principalmente, pela maneira com que faz a interligação entre a análise e a estética, e de que maneira, através da análise, Hoffmann defende uma determinada concepção a respeito da música e do gênio.

O texto começa com uma apologia da música instrumental: para Hoffmann, ela exprime de maneira pura a própria essência da arte, e somente nela é que podemos reconhecer essa essência:

\footnotetext{
423 SCHNAUS, P. E.T.A. Hoffmann als Beethoven-Rezensent der Allgemeinen Musikalischen Zeitung. München: Musikverlag Emil Katzbichler, 1977, p. 43.

${ }^{424}$ Além da recensão sobre a $5 \mathrm{a}$. Sinfonia, Hoffmann escreveu também sobre a Abertura Coriolano (Jun. 1812), os Trios Op. 70 (Set. 1812 e Jan./Fev. 1813), a Missa em Dó Maior (Maio 1813) e a música para o "Egmont", de Goethe (Jun. 1813). Na opinião do musicólogo Peter Schnaus "é com razão que as cinco recensões sobre Beethoven são tomadas freqüentemente como as publicações mais importantes de Hoffmann no campo da crítica musical" (Cf. SCHNAUS, P. E.T.A. Hoffmann als Beethoven-Rezensent, p. 45).

${ }^{425}$ HOFFMANN, E. T. A. Briefe und Tagebücher I, p. 316.

${ }^{426}$ SCHNAUS, P. E.T.A. Hoffmann als Beethoven-Rezensent, p. 14.
} 
Ela é a mais romântica das artes [romantischste aller Künste] poder-se-ia quase dizer: a única puramente romântica. A lira de Orfeu abriu as portas do Hades. A música abre ao homem um reino desconhecido [unbekanntes Reich]; um mundo que nada tem em comum com o mundo exterior dos sentidos [äußern Sinnenwelt] que o circunda, e no qual ele deixa para trás todos os sentimentos definíveis através de conceitos, para se entregar ao indizível [Unaussprechlichen]. Quão pouco os compositores de música instrumental reconheceram essa essência característica [eigentümliche Wesen] da música, ao tentar representar aqueles sentimentos determináveis [bestimmbaren Empfindungen], ou até mesmo acontecimentos, tratando de maneira plástica a arte que é a mais oposta às artes plásticas! ${ }^{427}$

Hoffmann foi buscar em Wackenroder e Tieck a concepção da música como uma linguagem do inefável, capaz de expressar aquilo que era inacessível à linguagem das palavras e dos conceitos. Mas ele trata a música sob uma ótica diversa daqueles outros dois autores. Em Hoffmann entra em cena o conceito de "romântico", que não aparecia nos textos de Wackenroder e Tieck: dentre todas as artes, a música é aquela que, segundo Hoffmann irá incorporar esse princípio romântico da maneira mais pura, revelando ao homem um reino desconhecido, que nada tem a ver com o mundo dos sentidos [Sinnenwelt], um reino do inefável, do incomensurável, do infinito. ${ }^{428}$ Assim, coloca-se a questão: de que maneira devemos interpretar o conceito de romantismo neste texto? Como compreender a afirmação feita por Hoffmann de que a música é a mais romântica de todas as artes? A esse respeito, o musicólogo Peter Schnaus fez a seguinte observação:

Hoffmann utiliza o conceito "Romântico" como um patrimônio público literário e estético, sem explicá-lo ou defini-lo no interior de sua recensão, e pressupõe, com isso, que se deva compreender esse conceito (que já tinha um longo processo de desenvovimento) no

\footnotetext{
${ }^{427}$ HOFFMANN, E. T. A. Schriften zur Musik, p. 34.

${ }^{428}$ Cf. SCHNAUS, P. E.T.A. Hoffmann als Beethoven-Rezensent, p. 58.
} 
sentido das correntes literárias do início de 1800 (Irmãos Schlegel, Tieck, Novalis). ${ }^{429}$

Fica claro, portanto, que o termo "romantismo" não é empregado aqui por Hoffmann no mesmo sentido em que o vemos empregado nos manuais e enciclopédias de música, como fizeram alguns comentadores. ${ }^{430} \mathrm{Na}$ realidade, esse conceito deve ser compreendido a partir da literatura e da teoria estética de sua época. É a partir desse contexto que devemos interpretar, por exemplo, a afirmação feita por Hoffmann de que as composições instrumentais de Haydn, Mozart e Beethoven "respiram um mesmo espírito romântico [romantischen Geist], o qual está justamente na mesma compreensão íntima da essência característica da arte". 431

\section{Música instrumental pura como modelo da arte romântica}

Nas paráfrases poéticas que utiliza para descrever o caráter das obras de Haydn, Mozart e Beethoven, Hoffmann define algumas das características do Romantismo que se manifesta na música. Nas composições de Haydn haveria um "desejo melancólico" [wehmütiges Verlangen]. As obras de Mozart seriam um "pressentimento do infinito" [Ahnung des Unendlichen], e colocariam o ouvinte num "anseio indizível" [unaussprechlicher Sehnsucht]. A música de Beethoven desperta "a dor do anseio infinito" [Schmerz der unendlichen Sehnsucht] e "suscita aquele

\footnotetext{
${ }^{429}$ SCHNAUS, P. E.T.A. Hoffmann als Beethoven-Rezensent, p. 58.

${ }^{430}$ Charles Rosen, por exemplo, no primeiro capítulo de seu livro The Classical Style, escreve que a nova arte criada por Haydn, Mozart e Beethoven "é, em parte por convenção, chamada de estilo clássico". Mas Rosen continua: "Essa não é a denominação de E. T. A. Hoffmann: para ele, Haydn e Mozart foram os primeiros compositores 'românticos'. Mas qualquer que seja o nome que se dê, a originalidade desse novo estilo e sua integridade foram sentidas muito cedo". (Cf. ROSEN, C. The Classical Style: Haydn, Mozart, Beethoven. London: Faber and Faber, 1976, p. 19).

${ }^{431}$ HOFFMANN, E. T. A. Schriften zur Musik, p. 35.
} 
anseio infinito [unendliche Sehnsucht], que é a essência do Romantismo". ${ }^{432}$

Como mostrou o musicólogo Carl Dahlhaus, o principal teórico sobre o qual Hoffmann fundamenta o seu conceito de romantismo é o escritor Jean Paul, especialmente nos parágrafos dedicados ao conceito de poesia romântica de sua Vorschule der Ästhetik (1804). Ali, Jean Paul define o elemento romântico da seguinte forma: "o Romântico é o belo sem limitações, ou o infinito belo, assim como há um [infinito] sublime". ${ }^{433}$

Essa relação entre infinitude e romantismo é um dos topos desse conceito, e que, de certa forma, tem suas origens no conceito schilleriano do "sentimental". ${ }^{434}$ Com efeito, no ensaio sobre poesia ingênua e sentimental, Schiller afirmava que toda poesia tem de possuir um conteúdo infinito [unendlichen Gehalt] e, enquanto o poeta ingênuo se caracteriza pela perfeição na limitação [Begrenzung], pela exposição absoluta de seu objeto, o poeta sentimental é poderoso pela arte do infinito [Kunst des Unendlichen]. ${ }^{435}$ Se a força maior dos artistas antigos está "na simplicidade das formas [Einfalt der Formen], naquilo que se pode expor sensivelmente [sinnlich darstellbar] e é corpóreo [körperlich]", a força do artista moderno está na riqueza da matéria [Stoff], ou seja, "naquilo que não se pode expor [undarstellbar] e é inefável [unaussprechlich], em suma, naquilo que nas obras de arte se chama espírito [Geist]" ${ }^{436} \mathrm{O}$ artista sentimental afasta todos os limites de seu

\footnotetext{
${ }^{432}$ HOFFMANN, E. T. A. Schriften zur Musik, p. 35-36.

433 PAUL, J. Vorschule der Ästhetik. Hamburg: Felix Meiner, 1990, p. 88 ("Das Romantische ist das Schöne ohne Begrenzung, oder das schöne Unendliche, so wie es ein erhabenes gibt").

${ }^{434}$ Contudo, deve-se ressaltar que isso não significa que os autores românticos concordassem incondicionalmente com Schiller. No § 21 de sua Vorschule der Ästhetik, Jean Paul faz inúmeras críticas a Schiller (cf. especialmente p. 85-6).

${ }^{435}$ SCHILLER, F. Über naive und sentimentalische Dichtung, p. 37. Trad. Bras. Poesia ingênua e sentimental, p. 63.

${ }^{436}$ SCHILLER, F. Über naive und sentimentalische Dichtung, p. 38. Trad. Bras. Poesia ingênua e sentimental, p. 63. Cf. também com a definição kantiana de espírito (KANT, KdU § 49, B 192).
} 
objeto [alle Grenzen entfernt] e se caracteriza pela exposição de um absoluto [Darstellung eines Absoluten]. ${ }^{437}$ Disto resulta que sua tarefa é uma tarefa infinita [unendliche Aufgabe], pois o Absoluto é uma meta alcançável somente numa progressão infinita. $O$ conceito de "sentimental", tal como empregado por Schiller está ligado à atividade reflexionante: enquanto o poeta ingênuo "segue apenas a natureza simples e a sensibilidade, e se limita à mera imitação da realidade" [Nachahmung der Wirklichkeit], o poeta sentimental age de modo inteiramente diverso:

Este reflete [reflektiert] sobre a impressão que os objetos Ihe causam e tão somente nessa reflexão [Reflexion] funda-se a comoção [Rührung] a que ele próprio é transportado e transporta. O objeto [Gegenstand], aqui, é referido a uma Idéia [auf eine Idee bezogen], e sua força poética reside apenas nessa referência. Por isso, o poeta sentimental sempre tem de lidar com duas representações e sensações conflitantes, com a realidade enquanto limite e com sua Idéia enquanto infinito [Unendlich]. ${ }^{438}$

Como bem observou Márcio Suzuki, a marca do poeta sentimental é a justamente essa atividade reflexionante e, é na reflexão que está "a diferença essencial entre o poeta ingênuo e o sentimental". ${ }^{439}$

Esse parentesco entre o sentimental e o romântico, bem como entre a música moderna e a arte sentimental é acentuado também por Friedrich Schlegel na "Carta sobre o romance":

${ }^{437}$ SCHILLER, F. Über naive und sentimentalische Dichtung, p. 70-71. Trad. Bras. Poesia ingênua e sentimental, p. 85.

${ }^{438}$ SCHILLER, F. Über naive und sentimentalische Dichtung, p. 38. Trad. Bras. Poesia ingênua e sentimental, p. 64.

${ }^{439}$ In: SCHILLER, F. Poesia ingênua e sentimental, p. 27. Suzuki nota ainda que "o poeta sentimental não apenas reflete, mas também convida o leitor a percorrer o mesmo fio de raciocínio em relação ao objeto. As mesmas operações de espírito do criador têm de ser desencadeadas no espírito do leitor, sem o qual não há comunicação. Com essa explicitação do vínculo entre o 'produtor' e o 'fruidor', Schiller retoma também um tema fundamental da filosofia fichteana, a saber, o de que a doutrina-da-ciência só é compreensível na medida em que se refaz, pela imaginação, o caminho trilhado por seu autor" (Idem, Ibidem). 
[...] segundo meu ponto de vista e no meu modo de falar, romântico [das romantisch] é justamente o que nos expõe [darstellt] uma matéria sentimental [sentimentalen Stoff] em uma forma fantástica [fantastischen Form], [ou seja, em uma forma determinada inteiramente pela fantasia]. ${ }^{440}$ Esqueça por um momento o significado corriqueiro e pejorativo [da palavra] sentimental [des Sentimentalen], em que por esta denominação se entende tudo o que comove de modo trivial e lacrimoso [...]. Pense antes em Petrarca ou em Tasso [...]. Tasso é mais musical, e Ariosto não é seguramente dos piores no elemento pitoresco. A pintura não é mais tão fantástica [fantastisch] como era em muitos mestres da Escola veneziana. A música moderna, por outro lado, [...] permaneceu no todo tão fiel a seu caráter [Charakter] que ousaria chama-la, sem timidez, uma arte sentimental [sentimentale Kunst]. ${ }^{441}$

A tendência em direção ao infinito é, também para Schlegel, uma das principais características desse elemento romântico. No famoso fragmento 116 do Athenäum, ele afirma que "a poesia romântica é uma poesia universal progressiva":

Só ela é infinita, só ela é livre, e reconhece, como sua lei primeira, que o arbítrio [Willkür] do poeta não está sujeito a nenhuma lei. A poesia romântica é o único gênero que é, mais do que um gênero, como que a própria arte poética: pois num certo sentido toda poesia é, ou deveria ser, romântica. ${ }^{442}$

A relação entre o elemento romântico e a música pode ser justificada de duas formas principais. Primeiramente, devido ao fato de que, para Schlegel, o elemento enigmático [das Rätselhafte] é a maior fonte do fantástico [Fantastischen]. ${ }^{443}$ Ora, se nos lembrarmos dos textos de Wackenroder e Tieck, veremos que a música instrumental passou a ser valorizada por eles justamente devido às suas qualidades de linguagem misteriosa e enigmática. Porém, mais do que isto, a música instrumental

\footnotetext{
440 Este último trecho entre colchetes é um acréscimo feito pelo próprio Schlegel na segunda versão do texto, publicada em 1823 no quinto volume de suas obras completas. ${ }^{441}$ SCHLEGEL, F. Gespräch über die Poesie, p. 333. Trad. Bras. Conversa sobre a poesia, p. 65.

${ }^{442}$ In: SCHLEGEL, F. Conversa sobre a poesia, p. 101.

${ }^{443}$ SCHLEGEL, F. Gespräch über die Poesie, p. 334. Trad. Bras. Conversa sobre a poesia, p. 66.
} 
está intimamente ligada à interioridade subjetiva, tal como o elemento romântico.

\section{O Romantismo e o Sublime}

Foi principalmente por conta da relação entre o elemento romântico e o aspecto da interioridade que se buscou ligar o Romantismo à religião cristã. No $§ 23$ da Vorschule der Ästhetik, Jean Paul afirma: "a origem e o caráter de toda nova poesia pode ser deduzida tão facilmente do Cristianismo, que se poderia chamar a poesia romântica igualmente como poesia cristã". ${ }^{444}$ Ele afirma que a religião cristã extirpou o mundo dos sentidos [Sinnenwelt] - ou seja, tudo o que é limitado à finitude e ao corpóreo - e o substituiu pelo mundo da interioridade ou, como Jean Paul também o denomina, pelo mundo dos espíritos [Geister-Welt], onde tudo é infinito [unendlich]:

[...] assim floresceu na poesia o reino do infinito [Reich des Unendlichen] por sobre as cinzas da finitude [Endlichkeit]. Anjos, demônios, santos, beatos e o infinito não tinham formas corpóreas [Körper-Formen] nem corpos de deuses [Götter-Leiber]; em compensação o colossal [Ungeheure] e o imenso [Unermeßliche] abriram suas profundezas; ao invés da serena alegria [heitern Freude] grega, apareceram ou 0 anseio infinito [unendliche Sehnsucht] ou a beatitude inefável [unaussprechliche Seligkeit] - a danação intemporal e sem barreiras - o medo dos espíritos [Geisterfurcht], que estremecem [schaudert] diante de si mesmos. [...] $\mathrm{Na}$ longa noite do infinito [Nacht des Unendlichen] o homem estava freqüentemente mais atemorizado do que esperançoso". ${ }^{445}$

Se compararmos o vocabulário utilizado por Jean Paul e aquele utilizado por Hoffmann, iremos verificar uma coincidência quase literal de certos termos e frases. E a tentativa de Hoffmann de unificar essa concepção romântica da arte com a tradição do sublime já está

\footnotetext{
${ }^{444}$ PAUL, J. Vorschule der Ästhetik, p. 93.
}

${ }^{445}$ PAUL, J. Vorschule der Ästhetik, p. 93. 
prefigurada também no texto de Jean Paul. Com efeito, os termos típicos da categoria do "romântico", tais como: infinitude [Unendlichkeit], anseio [Sehnsucht], pressentimento [Ahnung] estão, na recensão de Hoffmann, constantemente ligadas às categorias do sublime, tais como: colossal [Ungeheure], imenso [Unermeßlich], medo [Furcht], etc., as quais, por sua vez estavam indissoluvelmente ligadas à idéia do sublime pelo mesnos desde a publicação do livro do filósofo inglês Edmund Burke: Uma investigação filosófica sobre a origem de nossas idéias do sublime e do belo (1757). Ali, o sublime é definido como sendo a "mais forte emoção que a mente [mind] é capaz de sentir". Uma vez que as idéias de dor são "muito mais poderosas do que aquelas que provêm do prazer", Burke pode afirmar que:

Tudo aquilo que seja de algum modo capaz de incitar as idéias de dor e de perigo, isto é, que seja de alguma maneira terrível ou relacionado a objetos terríveis ou atua de um modo análogo ao terror constitui uma fonte do sublime. ${ }^{446}$

$\mathrm{Na}$ segunda parte de seu livro, Burke enumera diveras paixões relacionadas ao sublime: a principal delas é o terror, que é considerado como o princípio primordial do sublime ${ }^{447}$ Assim, tudo o que causa medo, assombro e espanto, são também considerados como igualmente sublimes. A relação entre a música instrumental e o sublime é indicada também por Burke. Isso se deve ao fato de que a obscuridade [obscurity] é necessária para tornar algo extremamente terrível. Quanto mais escuro, incerto, confuso e terrível um objeto se apresentar a nós, tanto mais nós o sentiremos como sublime. É exatamente isto que abre caminho para a

\footnotetext{
${ }^{446}$ BURKE, E. Uma investigação filosófica sobre a origem de nossas idéias do sublime e do belo. Trad. E. A. Dobránszky. Campinas: Papirus, 1993, p. 48. Deve-se notar que Burke faz uma ressalva importante a respeito do sublime: "Quando o perigo ou a dor se apresentam como uma ameaça decididamente iminente, não podem proporcionar nenhum deleite e sao meramente terríveis [terrible]; mas quando sao menos prováveis e de certo modo atenuadas, podem ser - e são - deliciosas [delightful]" (Idem, ibid.).

${ }^{447}$ BURKE, E. Uma investigação filosófica, p. 66.
} 
valorização da música instrumental, pois é justamente devido à sua obscuridade que a música pura torna-se capaz de suscitar o sublime:

A clareza de imagens é tão pouco necessária para incitar as paixões que se pode prescindir desse auxílio, mediante o recurso a certos sosns apropriados àquele objetivo, como provam os efeitos reconhecidos e poderosos da música instrumental. Na verdade uma grande clareza pouco contribui para incitar as paixões, pois é de certo modo inimiga de todo e qualquer entusiasmo. ${ }^{448}$

Tendo em vista que uma idéia obscura nos afeta mais do que uma idéia clara, e que "é o nosso desconhecimento das coisas que dá origem a toda e qualquer admiração de nossa parte e principalmente incita nossas paixões", Burke considera que "as idéias de eternidade e de infinito estão entre as que nos provocam a mais profunda impressão", pois talvez não haja "nada que compreendamos tão pouco quanto elas": 449

[...] dificilmente alguma coisa pode impressionar o espírito por sua grandiosidade, se não se aproxima, de algum modo, da infinitude [infinity], o que nenhuma pode fazer enquanto somos capazes de perceber seus limites. Ora, ver distintamente um objeto e perceber seus limites é a mesma coisa. Uma idéia clara é, portanto, um outro nome para uma idéia pequena. ${ }^{450}$

Ainda acerca da infinitude, Burke observa ela tende a preencher a mente com uma espécie de "horror deleitoso [delightful horror], que é o efeito mais genuíno e o teste mais infalível do sublime". ${ }^{451}$ Dentre as demais fontes do sublime enumeradas por Burke, destacamos ainda o poder (que está ligada à dor e à violência e, portanto, ao terror), as privações em geral (vazio, trevas, solidão e silêncio), a vastidão, a dificuldade, a magnificência e a subitaneidade. Numa comparação entre o sublime e o belo, Burke afirma:

\footnotetext{
${ }^{448}$ BURKE, E. Uma investigação filosófica, p. 68.

${ }^{449}$ BURKE, E. Uma investigação filosófica, p. 69.

${ }^{450}$ BURKE, E. Uma investigação filosófica, p. 70.

${ }^{451}$ BURKE, E. Uma investigação filosófica, p. 78.
} 
Os objetos sublimes possuem dimensões muito grandes, ao passo que os belos são comparativamente pequenos [...], a obscuridade é inimiga da beleza; as trevas e as sombras são essenciais ao grandioso; a beleza deve ser leve e delicada, o grandioso requer a solidez [...]. Essas idéias [do sublime e do belo] são, com efeito, de naturezas muito diferentes, uma fundada na dor, a outra no prazer. ${ }^{452}$

\section{A Sinfonia e o sublime: a ode pindárica como paradigma da obra de arte genial.}

Embora não de maneira tão radical como na recensão de Hoffmann, a relação entre o gênero sinfônico e a idéia do sublime já estava apontada no verbete Symphonie ${ }^{453}$, escrito por Johann Abraham Peter Schulz para a Allgemeine Theorie der Schönen Künste (editada por Sulzer). ${ }^{454}$

Nesse verbete, Schulz considera que a sinfonia se caracterizaria pela expressão do estilo elevado ou sublime: "A Sinfonia é especialmente apropriada para a expressão do grandioso [Großen], do solene [Feyerlichen] e sublime [Erhaben]". Um pouco mais adiante, ele escreve ainda:

Um tal Allegro na Sinfonia é o que uma Ode Pindárica é na Poesia; tal como esta, ele eleva [erhebt] e comove profundamente [erschüttert] a alma do ouvinte, e requer o mesmo espírito, a mesma imaginação sublime e o mesmo conhecimento da arte [Kunstwissenschaft], para ser bem-sucedido ali. ${ }^{455}$

A resposta à pergunta acerca de como conciliar a concepção de música como ruído agradável (que aparece no verbete Instrumentalmusik, por exemplo) com a idéia da sinfonia como expressão do sublime, pode ser respondida se levarmos em consideração que as duas foram escritas por autores distintos, como já mencionamos anteriormente. Assim, é

\footnotetext{
${ }^{452}$ BURKE, E. Uma investigação filosófica, p. 130.

${ }^{453}$ A tradução desse verbete está disponível em apêndice, ao final deste trabalho.

${ }^{454} \mathrm{Cf}$. DAHLHAUS, C. Klassische und romantische Musikästhetik, p. 99.

${ }^{455}$ In: SULZER, Allgemeine Theorie der Schönen Künste, Bd. 2, p. 1122.
} 
importante notar que ambas espelharam concepções diferentes a respeito da música (uma mais conservadora e outra mais progressiva), e que a teoria do gênio que Hoffmann vai tentar desenvolver é devedora dessa última concepção. Mas como entender essa referência ao sublime no verbete sobre a sinfonia escrito por Schulz? E qual o motivo dessa analogia entre a sinfonia e a ode? Para responder a essas questões, convém examinar alguns aspectos do estudo clássico de Karl Viëtor acerca da idéia do sublime na literatura alemã. ${ }^{456}$

Viëtor observa que o conceito de "sublime" não possuía, na Antigüidade, o mesmo significado que ela passou a ter a partir do século XVIII: tanto os gregos como os romanos não ligavam ao sublime as idéias de obscuridade e infinitude que seriam características desse conceito a partir do século XVIII. No tratado de Longino, por exemplo, o sublime é definido como sendo "o ponto mais alto, a eminência do discurso", e ele visa não à persuasão, mas sim ao êxtase dos ouvintes: o maravilhamento causado pelo sublime supera a persuasão e o agrado, e arrastam o ouvinte com uma força irresistível. ${ }^{457}$

Como bem observa Viëtor, embora seja preciso que se possua o talento para o sublime como dom inato, a técnica da expressão grandiosa pode ser aprendida. ${ }^{458} \mathrm{Com}$ efeito, Longino considera a aptidão à palavra (ou seja, um dom inato) como fundamento comum às cinco fontes do sublime enumeradas por ele. ${ }^{459}$ Mas dessas cinco fontes, somente as duas primeiras são dons naturais (a saber: a faculdade de lançar-se aos pensamentos elevados; e a paixão violenta e criadora de entusiasmo). As demais fontes (qualidade da fabricação das figuras, nobreza da expressão, composição digna e elevada), passam também pelo âmbito da

\footnotetext{
${ }^{456}$ VIËTOR, K. "Die Idee des Erhabenen in der deutschen Literatur". In: Geist und Form: Aufsätze zur deutschen Literaturgeschichte. Bern: A. Francke Verlag, 1952, p. 234-266. ${ }^{457}$ LONGINO. Do Sublime. Trad. Bras. F. Hirata. São Paulo: Martins Fontes, 1996, p. 44. ${ }^{458}$ VIËTOR, K. "Die Idee des Erhabenen in der deutschen Literatur", p. 239.

${ }^{459}$ LONGINO. Do Sublime. Trad. Bras. F. Hirata. São Paulo: Martins Fontes, 1996, p. 52.
} 
técnica, e podem, portanto, ser aprendidas e ensinadas. Assim, pode-se deduzir a partir destas indicações, que não basta que o orador possua apenas um talento natural para o sublime: é preciso que ele esteja unificado a uma técnica, para conseguir produzir seus efeitos.

Quanto à relação do sublime com a ode, esta parece ter sido estabelecida pela primeira vez por Boileau, em seu Discours sur l'Ode, sendo retomada também por Batteux e outros autores. ${ }^{460}$ Como bem notou Jochen Schmidt ${ }^{461}$, o gênero poético da Ode foi considerado, durante um bom tempo, como um paradigma da obra de arte genial. No artigo escrito por Addison, Píndaro é citado como um modelo de poeta genial natural (isto é, marcado por uma espontaneidade sem regras e por "um fogo e impetuosidade naturais"). ${ }^{462} \mathrm{Da}$ mesma forma, nas Conjectures on Original Composition (1759), de Edward Young ${ }^{463}$, Píndaro aparece como protótipo do gênio. ${ }^{464}$

Se na tradição inglesa a Ode pindárica era considerada sobretudo como produto de um gênio natural, na tradição alemã as coisas vão, aos

${ }^{460}$ Cf. A esse respeito VIËTOR, K. "Die Idee des Erhabenen in der deutschen Literatur", p. 240-43. Viëtor nota ainda que a primeira tradução de Longino para uma língua moderna foi editada por Boileau, no mesmo ano em que ele publicou sua Art Poétique (1674). A primeira tradução alemã de Longino foi publicada somente em 1737, por Karl Heinrich Heineken, na cidade de Dresden. Mas Viëtor considera que o ponto de virada decisivo na história da idéia do sublime deu-se na Inglaterra, com a publicação do tratado de Burke (1757) e a sua tentativa de realizar uma clara separação entre as idéias do sublime e do belo, o que influenciou decisivamente a estética moderna, sendo um marco importante em direção ao Romantismo (Idem, p. 251-55).

${ }^{461}$ SCHMIDT, J. Die Geschichte des Genie-Gedankens I, p. 180.

${ }^{462}$ ADDISON, J. The Spectator. Vol. II. London: J. \& R. Tonson, 1744, p. 298.

${ }^{463}$ YOUNG, E. Conjectures on original composition. London: A. Millar, 1759, p. 30.

${ }^{464}$ Tanto em Addison como em Young, o par Píndaro-Shakespeare (a Ode Pindárica entre os Antigos e o Drama Shakespeariano entre os modernos) já aparece como paradigma da genialidade natural: "uma estrela de primeira magnitude entre os Modernos foi Shakespeare; entre os Antigos, Píndaro". YOUNG, E. Conjectures on original composition. London: A. Millar, 1759, p. 30. 
poucos, mudando de figura. Nos Literaturfragmente, Herder observa que a criação de palavras, a conexão dos períodos, a métrica variada das odes pindáricas "não é obra do frenesi selvagem [wilder Phrenesie]", mas tudo pressupõe "tanta escolha [Wahl] e uma arte [tão] excelente [vortreffliche Kunst], que [...] a meu ver, Píndaro alcançou o mais alto grau de arte poética entre os gregos". ${ }^{465}$ Dessa forma, a concepção da ode como um gênero poético natural, originado apenas a partir do calor dos sentimentos do poeta e desligado de normas métricas e estróficas ${ }^{466}$ vai aos poucos se modificando de tal forma que essa aparente falta de ordem característica da ode e a audácia das formas de expressão utilizadas pelo poeta passam a ser vistas como resultado de uma escolha $e$ planejamento. Embora, como afirmou Sulzer, o plano [Plan] do poeta esteja "freqüentemente muito oculto [sehr versteckt]"467, é justamente nesse plano oculto do poeta que outros autores enxergavam o seu gênio poético. ${ }^{468}$ Como bem observa Schmidt, a desordem é apenas aparente: a ode tem uma ordem e uma lógica conscientemente ocultadas e, por trás dessa aparência caótica, na realidade se esconde uma extraordinária capacidade artística. ${ }^{469}$

De maneira análoga, a recensão de Hoffmann procurará evidenciar, através da análise musical, toda a reflexão [Besonnenheit] necessária para a composição da Quinta Sinfonia. Tal como exigia J. A. P. Schulz em seu verbete anteriormente citado, Hoffmann tentará demonstrar que a "imaginação sublime" anda de mãos dadas com o "conhecimento da arte" [Kunstwissenschaft] $^{470}$ e que só essa combinação entre inspiração e

\footnotetext{
${ }^{465}$ Apud SCHMIDT, J. Die Geschichte des Genie-Gedankens I, p. 188.

${ }^{466}$ SCHMIDT, J. Die Geschichte des Genie-Gedankens I, p. 196.

467 SULZER, J. G. Allgemeine Theorie der Schönen Künste, Bd. 2. Leipzig: Weidmann, 1774 , p. 833.

468 Jochen Schmidt cita como exemplo a 51. Literaturbrief de Lessing. Cf. SCHMIDT, J. Die Geschichte des Genie-Gedankens I, p. 219.

${ }_{469}$ SCHMIDT, J. Die Geschichte des Genie-Gedankens I, p. 218-19.

470 In: SULZER, J. G. Allgemeine Theorie der Schönen Künste, Bd. 2, p. 1122.
} 
reflexão pode dar origem a uma obra de arte musical capaz de mover "a alavanca do terror [Schauer], do temor [Furcht], do horror [Entsetzen], da dor [Schmerz]", e suscitar "aquele anseio infinito [unendliche Sehnsucht], que é a essência do Romantismo". ${ }^{471}$

\section{A concepção do gênio musical na recensão da "Quinta Sinfonia"}

Os críticos musicais contemporâneos a Hoffmann consideravam as obras de Beethoven, em geral, segundo dois pontos de vista principais: ou como resultado apenas do controle racional do compositor (em detrimento da espontaneidade criativa), ou então, como resultado da fantasia irracional do gênio e da ausência de regras.

Numa recensão do Trio para piano, clarinete e violoncelo op. 11, podemos ler, por exemplo: "[O compositor], com seu conhecimento harmônico incomum e amor pela composição séria, nos daria muitas [obras] de boa qualidade [...], se quisesse escrever sempre de maneira mais natural do que rebuscada". ${ }^{472}$ Numa outra recensão, acerca das Sonatas para piano e violino op. 12, lemos ainda:

É inegável: o Sr. van Beethoven segue um caminho próprio; mas que caminho bizarro e penoso! Erudito [gelehrt], erudito, e sempre erudito, e nenhuma natureza, nenhum canto! [...] Há [nessas obras] [...] uma procura por modulações incomuns, um asco pelos encadeamentos usuais, um acúmulo de dificuldade por cima de dificuldade, de modo que [o ouvinte] perde toda alegria e paciência com isso. ${ }^{47}$

Um outro exemplo pode ser visto numa crítica francesa publicada no Le Globe em maio de 1828: "De tempos em tempos encontramos [em

\footnotetext{
${ }^{471}$ HOFFMANN, Schriften zur Musik, p. 36.

472 [Anônimo] In: AmZ 1, Nr. 34 (22.05.1799), p. 541-42.

473 [Anônimo] In: AmZ 1, Nr. 36 (05.06.1799), p. 570-71.
} 
Beethoven] os defeitos da Escola alemã: mais bizarrice do que encanto, mais cálculo [calcul] do que inspiração verdadeira". ${ }^{474}$

Por outro lado, como dissemos, havia também críticos que acentuavam apenas o gênio irracional nas composições de Beethoven. Numa recensão sobre as Sonatas para piano Op. 10, podemos ler:

Sua abundância de idéias [...] ainda leva Beethoven, muito freqüentemente, a amontoá-las de maneira selvagem, umas sobre as outras e, de uma maneira algo bizarra, a agrupá-las de maneira a produzir não raro uma artificialidade obscura [dunkle Künstlichkeit] ou uma obscuridade artificial [künstliche Dunkelheit]. ${ }^{475}$

O autor de uma recensão sobre a $3^{\mathrm{a}}$. Sinfonia de Beethoven

(Eroica), publicada também na AmZ em 18.02.1807 afirmava ainda:

Esta composição, longa e extremamente difícil de se executar, é na verdade uma fantasia audaz e selvagem [kühne und wilde Phantasie]. Nela não faltam passagens ousadas e surpreendentes, nas quais se pode reconhecer o espírito cheio de talento de seu criador. [Mas] com muita freqüência, parece se perder completamente na ausência de regras [ins Regellose]. ${ }^{476}$

Até mesmo o julgamento de alguns compositores contemporâneos a Beethoven parecia seguir esse padrão. O relato de Ludwig Spohr acerca de uma apresentação da Quinta Sinfonia na cidade de Munique, em dezembro de 1815 é bastante ilustrativo a esse respeito:

Apesar de muitas belezas isoladas, [a Quinta Sinfonia] não forma um todo clássico [kein klassisches Ganze]. Em especial, falta imediatamente ao tema do primeiro movimento a dignidade que, a meu ver, o início de uma sinfonia deve necessariamente possuir. [...] O último movimento, com seu barulho que nada diz [nichtssagenden Lärm] é o menos satisfatório [...]. ${ }^{477}$

\footnotetext{
${ }^{474}$ Apud WALLACE, R. Beethoven's Critics. Cambridge: Cambridge University Press, 1989 , p. 107.

${ }^{475}$ Apud WALLACE, R. Beethoven's Critics, p. 8.

476 In: SCHNAUS, P. E.T.A. Hoffmann als Beethoven-Rezensent, p. 36.

477 SPOHR, L. Selbstbiographie. 1. Bd. Cassel und Göttingen: Georg H. Wigand, 1860, p. 229.
} 
Segundo o crítico George Grove, a Quinta Sinfonia foi freqüentemente caracterizada "como se fosse um milagre da irregularidade", como se Beethoven tivesse "abandonado as regras ordinárias que regulam a construção de uma peça musical" e colocado no papel a primeira coisa que vinha em sua mente. Dentre os defensores dessas idéias, Grove cita Berlioz e Fétis, o qual teria definido o estilo de Beethoven "como uma espécie de improvisação, ao invés de uma composição". ${ }^{478}$ Essas caracterizações da música de Beethoven parecem ser tributárias de uma certa concepção de gênio como puro dom da natureza e freqüentemente desprovido de gosto. Tal concepção era bastante comum na época, como podemos perceber através do verbete sobre o "Gênio" da Enciclopédie:

O gosto está freqüentemente separado do gênio. O gênio é um puro dom da natureza; o que ele produz é obra de um momento; o gosto é obra do estudo e do tempo; ele [o gosto] se atém ao conhecimento de uma grande quantidade de regras estabelecidas ou supostas; ele produz belezas que são apenas de convenção. Para que uma coisa seja bela segundo as regras do gosto, é preciso que ela seja elegante, acabada, trabalhada, sem o parecer: para ser do gênio, é preciso algumas vezes que ela seja descuidada; que ela tenha um ar irregular, escarpado, selvagem. O sublime e o gênio brilham em Shakespeare como relâmpagos numa longa noite, e Racine é sempre belo; Homero é pleno de gênio, e Virgílio, de elegância. As regras e as leis do gosto forneceriam entraves ao gênio; ele as quebra para voar ao sublime, ao patético, ao grande. [...] Enfim, a força e a abundância, uma certa rudeza, a irregularidade, o sublime, o patético: eis o caráter do gênio nas artes. ${ }^{47}$

Assim, não espanta que os críticos quisessem ver nas composições sinfônicas de Beethoven os exemplos acabados da irregularidade, da

\footnotetext{
${ }^{478}$ GROVE, G. Beethoven and his nine symphonies. 3. ed. New York: Dover, 1962, p. 142-43.

${ }^{479}$ In: DIDEROT, D. Oeuvres Esthétiques. Ed. P. Vernière. Paris: Garnier, 1994, p. 1112.
} 
rudeza e da fantasia selvagem do gênio, que despreza as regras em favor de sua necessidade de exprimir as paixões que o agitam.

Ora, é justamente contra esse tipo de concepção que Hoffmann vai se voltar em sua recensão. A teoria do gênio de Hoffmann considera a reflexão [Besonnenheit] e o estudo aprofundado da técnica como elementos inseparáveis da genialidade. Cabe notar que, assim como o conceito de romantismo, também o conceito de reflexão [Besonnenheit] empregado aqui por Hoffmann tem suas origens na Vorschule der Ästhetik de Jean Paul, o qual defende que o gênio não se caracterizaria apenas por sua fantasia (imaginação criadora), mas principalmente, por uma elevada reflexão [höhere Besonnenheit]. ${ }^{480}$ Para Jean Paul, é absurdo conceber um gênio desprovido de entendimento [Verstand]. No gênio todas as faculdades encontram-se reunidas: chiste [Witz], perspicácia [Scharfsinn], entendimento [Verstand], razão [Vernunft]. ${ }^{481} \mathrm{O}$ fogo da inspiração e o conhecimento erudito trabalham em conjunto; somente a concepção do todo é criada pela inspiração [Begeisterung], mas a elaboração das partes depende da reflexão. ${ }^{482}$ Somente 0 preconceito e uma interpretação equivocada, escreve Jean Paul, poderiam deduzir uma incompatibilidade entre 0 entusiasmo [Enthusiasmus] e a reflexão [Besonnenheit]. ${ }^{483}$

Além de Jean Paul, uma provável fonte para a teoria do gênio de Hoffmann poderia ser encontrada no Sistema do Idealismo Transcendental de Schelling ${ }^{484}$, no qual também se atribui um elevado valor à reflexão [Besonnenheit] do gênio. Schelling afirma que somente

\footnotetext{
${ }^{480}$ Jean Paul afirma não poder distinguir entre o gênio poético e o gênio filosófico: "os filósofos-inventores [erfindenden] foram todos poéticos". PAUL, J. Vorschule der Ästhetik, p. 56.

${ }^{481}$ PAUL, J. Vorschule der Ästhetik, p. 56.

${ }^{482}$ PAUL, J. Vorschule der Ästhetik, p. 59.

${ }^{483}$ PAUL, J. Vorschule der Ästhetik, p. 58.

${ }^{484}$ Numa anotação em seu diário, Hoffmann menciona o estudo da filosofia de Schelling. A esse respeito, ver: HOFFMANN, E. T. A. Briefe und Tagebücher I, p. 351.
} 
quando a inspiração está unida à reflexão é que o gênio consegue criar as obras de arte mais elevadas e que conseguem expor o infinito numa forma finita. 485

É devido a essa concepção do gênio como unidade de inspiração e reflexão que Hoffmann recorre ao emprego do procedimento analítico: pois é somente através da análise aprofundada da própria obra que se poderá mostrar unidade e a coerência interna da sinfonia, sua consistência e economia temática, capaz de produzir o máximo de variedade a partir de um material motívico mínimo. Contra os críticos que viam em Beethoven uma certa irregularidade e bizarrice, atribuídas à inspiração selvagem do gênio, Hoffmann procurará interpretar a Quinta Sinfonia como um todo orgânico, que se desenvolve inteiramente a partir de um único motivo que percorre todos os movimentos:

Assim como os estéticos artistas-medidores [Meßkünstler] freqüentemente deploraram a total falta de uma verdadeira unidade [Einheit] e de coerência interna [inneren Zusammenhang] em Shakespeare ${ }^{486}$; e somente o olhar aprofundado [apreende] que uma bela árvore, [com seus] botões e folhas, flores e frutos, resulta de uma única semente: da mesma forma, é somente um detalhamento [Eingehen] muito profundo da estrutura interna da música de Beethoven que revela a elevada reflexão [hohe Besonnenheit] do Mestre, reflexão esta que é inseparável do verdadeiro gênio e que é nutrida pelo contínuo estudo da arte [anhaltenden Studium der Kunst]. É no fundo de seu ânimo [Gemüt] que Beethoven porta o

\footnotetext{
${ }^{485}$ SCHELLING, Ausgewählte Schriften I, p. I/3, 618-619.

${ }^{486}$ Como bem notou Grove (Beethoven and his nine symphonies, p. 144), há uma notável semelhança entre as concepções de Hoffmann e Coleridge acerca do gênio e da forma orgânica produzida por este. Com efeito, Coleridge afirma que é preciso destruir a noção bastante popular de que Shakespeare teria sido um grande dramaturgo graças apenas a seu instinto. Ele considera errôneos os juízos segundo os quais Shakespeare seria um "selvagem", "irregular", "puro filho da natureza", etc. Para ele, o motivo desse erro está na confusão entre regularidade mecânica [mechanical regularity] e forma orgânica [organic form]: "A forma é mecânica quando imprimimos a um dado material uma forma pré-determinada e que não necessariamente provém das propriedades do material [...]. A forma orgânica, por outro lado, é inata; ela dá a forma a si mesma de dentro para fora, enquanto se desenvolve". COLERIDGE, S. T. The literary remains. Vol. 2. Ed. H. N. Coleridge. London: William Pickering, 1836, p. 61, 67.
} 
Romantismo da música, que ele exprime com elevada genialidade e reflexão em suas obras. ${ }^{487}$

Assim, a segunda parte da recensão dedica-se à análise pormenorizada da obra. ${ }^{488}$ Hoffmann descreve cada um dos movimentos e dedica especial atenção aos aspectos motívicos, harmônicos e da instrumentação da peça. Contudo, como bem observou Schnaus, é necessário salientar a diferença da análise realizada por Hoffmann em comparação com os procedimentos atuais. Na recensão da sinfonia, embora os aspectos mais gerais relativos à forma estivessem pressupostos, ela não constitui ainda um campo problemático de investigação. A harmonia, por exemplo, é abordada apenas em termos muito gerais, dando ênfase aos efeitos conseguidos pelas modulações inesperadas $^{489}$ e pela originalidade do encadeamento de certas passagens, como por exemplo:

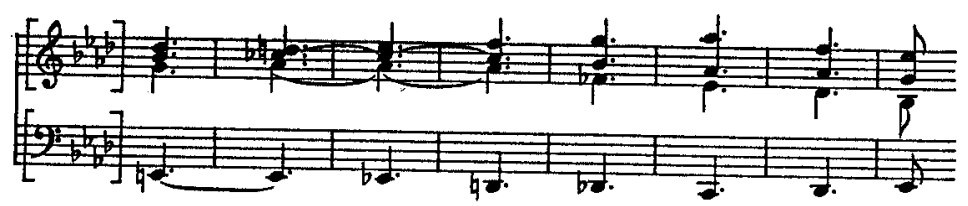

Ilustração Musical Nr. 1: Beethoven, Quinta Sinfonia ( $2^{\circ}$. Mov., cp. 41 e ss.).

Na análise melódica, Hoffmann não se detém tanto no material bruto e nas relações intervalares, mas a trata de acordo com tradição usual das recensões da $A m Z$, isto é, com caracterizações de afetos suscitados pela melodia, ou com adjetivos como: fluente, agradável, etc. ${ }^{490}$ No que diz respeito à dinâmica, Hoffmann acetua as mudanças extremas de

\footnotetext{
${ }^{487}$ HOFFMANN, Schriften zur Musik, p. 37.

${ }^{488}$ A tradução completa da recensão de Hoffmann está disponível em apêndice, ao final deste trabalho.

${ }_{489}$ Como no $3^{\circ}$. Movimento, compasso 27.

${ }^{490}$ Cf. SCHNAUS, P. E.T.A. Hoffmann als Beethoven-Rezensent, p. 52.
} 
intensidade da peça, e que ocorrem muitas vezes de maneira inesperada ${ }^{491}$ para o ouvinte da época. Também a instrumentação é analisada com detalhe. Hoffmann destaca a alternância entre cordas e sopros $^{492}$ e o fato de muitas passagens não se constituírem numa mera melodia acompanhada, como era o costume. A análise motívica é bem desenvolvida por Hoffmann, que identifica na idéia inicial da sinfonia o motivo unificador e que fornece coesão formal e organicidade à sinfonia inteira. $^{493}$

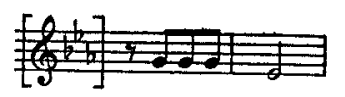

Ilustração Musical Nr. 2: Beethoven, Quinta Sinfonia (1 ${ }^{\circ}$. Mov., cp. 1-2).

No terceiro movimento, por exemplo, esse motivo reaparece da seguinte forma:

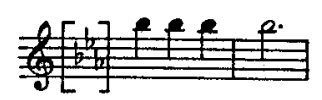

Ilustração Musical Nr. 3: Beethoven, Quinta Sinfonia ( $3^{\circ}$. Mov., cp. 27 e ss.).

A passagem para o quarto e último movimento é feita por uma transição que explora fragmentos do tema inicial ${ }^{494}$ do Scherzo combinados ao motivo inicial ${ }^{495}$ (como pedal de dominante ${ }^{496}$ nos baixos), conduzindo à modulação para a tonalidade de Dó Maior. ${ }^{497}$ Quanto à sua forma, o Allegro final poderia ser descrito como uma forma-sonata, porém com uma importante peculiaridade: Beethoven insere, de maneira

\footnotetext{
${ }^{491}$ Cf. $1^{\circ}$. Mov., cp. 227-228, $2^{\circ}$. Mov., cp. 28-29; $3^{\circ}$. Mov., cp. 18-19.

$4921^{\circ}$. Mov., cp. 196-227.

${ }^{493}$ Entretanto, Hoffmann não aponta a presença do motivo unificador no $2^{\circ}$. Mov., cp. 14 e 23; nem a semelhança existente entre os motivos do $2^{\circ}$. Mov., cp. 14 e o Trio do $3^{\circ}$. Mov., cp. 158-59, bem como o $4^{\circ}$. Mov., cp. 44. A presença do motivo se faz notar ainda sob forma de aumentação rítmica no $4^{\circ}$. Mov., cp. 150, 432 e 438, por exemplo.

${ }^{494} 3^{\circ}$. Mov., cp. 339.

${ }^{495} 3^{\circ}$. Mov., cp. 325.

${ }^{496} 3^{\circ}$. Mov., cp. 350.

${ }^{497} 4^{\circ}$. Mov., cp. 1.
} 
inesperada, um trecho do terceiro movimento (em dó menor) logo após o final do desenvolvimento. Embora Hoffmann assinale o reaparecimento do tema do Scherzo no último movimento, ele não dá tanta ênfase à originalidade desse procedimento. ${ }^{498}$

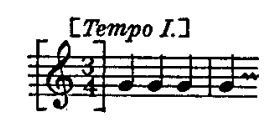

Ilustração Musical Nr. 4: Beethoven, Quinta Sinfonia (4‥ Mov., cp. 160 e ss.).

No entanto, deve-se ressaltar que não se trata aqui apenas do reaparecimento daquela idéia inicial unificadora, do motivo que está na base da sinfonia inteira, mas da interrupção do discurso e inserção de um trecho relativamente longo do movimento anterior (54 compassos, no total), num momento em que o ouvinte estaria esperando a reexposição do tema. ${ }^{499}$

$\mathrm{Na}$ terceira parte da recensão, dedicada às considerações finais, Hoffmann não se limita apenas aos usuais comentários acerca da dificuldade técnica de execução da peça, da qualidade de impressão da partitura ou sobre a redução para piano. Logo após a parte analítica ele retoma as considerações estéticas, procurando relacionar uma com a outra. Assim, ele observa que embora a sinfonia, considerada como um

\footnotetext{
${ }^{498}$ Embora o juízo do compositor L. Spohr a respeito da $5^{\text {a }}$. Sinfonia fosse, no conjunto, bastante desfavorável, a volta do tema do Scherzo no último movimento o impressionou por sua originalidade: "O último movimento, com seu barulho que nada diz [nichtssagenden Lärm] é o menos satisfatório; a volta do Scherzo ali é, porém, uma idéia tão feliz, que se tem que invejar o compositor por isso. Ela é de um efeito arrebatador! É uma pena que a volta do barulho apague tão depressa essa impressão!”. (SPOHR, L. Selbstbiographie. 1. Bd. Cassel und Göttingen: Georg H. Wigand, 1860, p. 229).

${ }^{499}$ Esse procedimento pouco usual de citação de um movimento anterior no último movimento ocorre também na Sinfonia Nr. 46 de Haydn (composta em 1772), mas não de maneira tão radical como em Beethoven (que só voltaria a empregar um efeito similar no quarto movimento de sua última sinfonia). Para uma análise mais detalhada do processo de interrupção e interpolação de material temático prévio na Sinfonia Nr. 46 de Haydn, ver: BONDS, M. E. Wordless Rhetoric: musical form and the metaphor of the oration. Cambridge, MA: Harvard University Press, 1991, p. 191-204 (em especial p. 203).
} 
todo, possa parecer a certos ouvintes "como uma genial rapsódia", ou seja, como uma sucessão livre e improvisada de materiais musicais, o ouvinte mais atento certamente irá perceber a sua unidade e, certamente será tomado "íntima e profundamente por um sentimento duradouro, que é justamente aquele anseio [Sehnsucht] inefável e cheio de pressentimentos, e nele será mantido até o acorde final" ${ }^{500}$ Esse efeito deve-se, segundo ele, não apenas aos detalhes técnicos como a disposição [Einrichtung] interna da instrumentação. Para Hoffmann, é sobretudo o "parentesco íntimo dos temas entre si, que engendra aquela unidade [Einheit] que mantém o ânimo [Gemüt] do ouvinte em um estado de espírito [Stimmung]". ${ }^{501}$ O parentesco existente entre os diversos movimentos e o motivo inicial que permeia toda a peça e que the dá sua enorme coerência interna devem-se à "genialidade refletida" [besonnene Genialität] do compositor. Embora a invenção [Erfindung] deva sua origem à espontaneidade do gênio de Beethoven, a análise técnica demonstrou que a execução [Ausführung] da composição foi levada a cabo com profunda reflexão [tiefer Besonnenheit]. Assim, Hoffmann demonstra que a Quinta Sinfonia não é produto da mera improvisação ou do entusiasmo do gênio, mas que ela é desenvolvida de acordo com as leis orgânicas inerentes ao próprio material temático. É devido, portanto, à união entre o entusiasmo criador e uma profunda reflexão que essa sinfonia expressa em alto grau, na visão de Hoffmann, o Romantismo da música [Romantik der Musik]. ${ }^{502}$

Essa interpretação da música de Beethoven é retomada por Hoffmann na recensão publicada em 1813, também na AmZ, a respeito dos Trios Op. 70. Tal como procedera na análise da Sinfonia, Hoffmann destaca incessantemente o trabalho temático e estrutural de Beethoven

\footnotetext{
${ }^{500}$ HOFFMANN, Schriften zur Musik, p. 50.

${ }^{501}$ HOFFMANN, Schriften zur Musik, p. 50.

${ }^{502}$ HOFFMANN, Schriften zur Musik, p. 50.
} 
também nos trios: utilizando um tema "simples, mas fecundo", Beethoven consegue estabeler um parentesco íntimo entre os movimentos e a "mais alta unidade [Einheit]" entre eles. ${ }^{503}$ Mas embora o domínio técnico seja imprescindível para o gênio, Hoffmann não deixa de observar que somente o conhecimento das regras mecânicas não é suficiente para se criar uma autêntica obra de arte. "Aquelas mesmas proporções numéricas", que nas obras dos "gramáticos desprovidos de gênio" permanecem apenas exemplos "rígidos e mortos" de um mero cálculo, nas obras de Beethoven transformam-se em "preparados mágicos, a partir dos quais surge um mundo mágico", que age intimamente sobre a alma do ouvinte. ${ }^{504} \mathrm{O}$ domínio harmônico de Beethoven é constantemente ressaltado por Hoffmann. Na passagem seguinte, por exemplo, ele coloca em relevo o efeito obtido por Beethoven através do emprego da enarmonia:

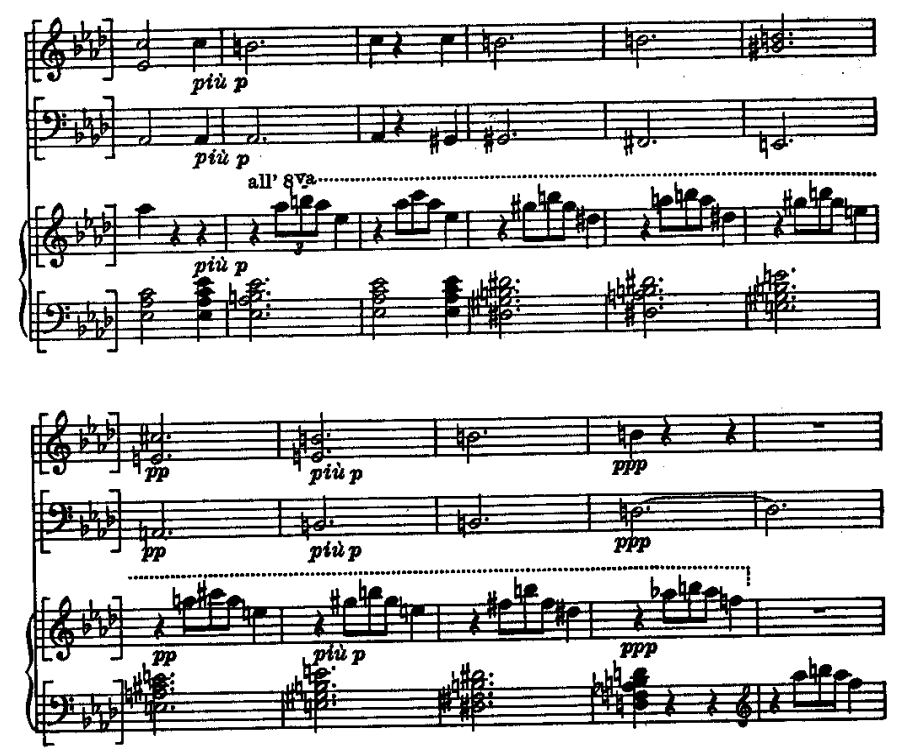

Ilustração Musical Nr. 5: Beethoven, Trio Op. 70 Nr. 2 (3º. Mov., cp. 96-106).

\footnotetext{
${ }^{503}$ HOFFMANN, Schriften zur Musik, p. 121.

${ }^{504}$ HOFFMANN, Schriften zur Musik, p. 121.
} 
Mas Hoffmann alerta:

Somente $O$ artista, que conteve 0 vôo excêntrico de seu gênio através do mais diligente estudo [eifrigste Studium] da arte, que adquiriu a mais alta reflexão [höchste Besonnenheit], e que agora reina sobre o reino interior da música, sabe de maneira clara e certa, onde deve empregar os meios mais surpreendentes [frappantesten] que a arte lhe oferece, [para obter] um efeito completo; ao passo que o aprendiz ou o imitador cego desprovido de gênio e de talento irá empregá-las erroneamente, justamente onde pretendia agir com todo o poder e força. ${ }^{505}$

Fica evidente, portanto, que o conceito de gênio utilizado por Hoffmann se afasta claramente daquele utilizado pelos teóricos da Empfindsamkeit e do Sturm und Drang. Embora o gênio não se submeta a regras exteriores, ele também não se deixa guiar simplesmente por sua fantasia: suas obras são resultado da união entre a consciência e o insconsciente, do dom natural e da habilidade técnica ou, na terminologia de Hoffmann, entre uma elevada genialidade [hohen Genialität] e uma reflexão [Besonnenheit] igualmente elevada. ${ }^{506}$ Justamente por incorporar esses elementos - trazidos à luz por meio da análise técnica das obras é que Beethoven pode ser tomado por Hoffmann como modelo do gênio na música. Argumentando contra aqueles críticos que viam nas obras instrumentais de Beethoven somente o produto de um gênio que, "sem se preocupar com a escolha [Auswahl] e formação [Formung] dos pensamentos [Gedanken], se abandona cegamente ao fogo arrebatador e aos estímulos [Anregungen] momentâneos de sua fantasia", ${ }^{507}$ Hoffmann afirma que "no que diz respeito à reflexão [Besonnenheit], dever-se-ia colocar [Beethoven] "inteiramente ao lado de Haydn e Mozart". 508

\footnotetext{
${ }^{505}$ HOFFMANN, Schriften zur Musik, p. 137.

${ }^{506}$ HOFFMANN, Schriften zur Musik, p. 119.

${ }^{507}$ HOFFMANN, Schriften zur Musik, p. 119.

${ }^{508}$ HOFFMANN, Schriften zur Musik, p. 119.
} 


\title{
CONSIDERAÇÕES FINAIS
}

\begin{abstract}
"O indispensável na obra de arte, o que a torna, muito mais do que um meio de prazer, um órgão do espírito, cujo análogo há de se encontrar em qualquer pensar filosófico ou político se for produtivo, é que contenha, mais do que idéias, matrizes de idéias, que nos forneça emblemas cujo sentido não cessará nunca de se desenvolver, que, precisamente por nos instalar num mundo do qual não temos a chave, [...] nos propicie enfim 0 pensamento como nenhuma obra analítica o pode fazer" ${ }^{509}$
\end{abstract}

Tanto os autores que se pretendem continuadores de uma tradição de escrita filosófica mais sistemática (como Michaelis), como aqueles que se mostram mais críticos a ela (como Wackenroder, Tieck e Hoffmann) partilham de um horizonte comum e apontam para um mesmo fato, a saber, para a crescente autonomia estética que a música instrumental pura adquire por volta do fim do século XVIII e princípio do XIX.

Dentre os elementos que contribuíram nesse processo poderíamos citar fatores de ordem social como, por exemplo, o aparecimento dos

${ }^{509}$ MERLEAU-PONTY, M. "A linguagem indireta e as vozes do silêncio". Trad. P. Souza Moraes. In: Textos selecionados (Col. Os Pensadores). São Paulo: Abril Cultural, 1984, p. 170. 
concertos públicos ${ }^{510}$ como lugar de realização da música autônoma, bem como fatores de ordem técnico-musical, dentre os quais mencionaríamos o aperfeiçoamento e invenção de novos instrumentos musicais e o surgimento de novas formas composicionais, como a forma-sonata. ${ }^{511}$ Com efeito, ao tomar a sinfonia como paradigma, a música instrumental deixa de ser vista como mero reforço da poesia ou da ação dramática, tornando-se modelo para todas as demais artes. ${ }^{512}$

No âmbito da história das idéias, um primeiro momento pelo qual a música adquire uma certa importância no âmbito das reflexões filosóficas da época se dá através das teorias sobre a origem das línguas, como se vê em Rousseau, por exemplo. Mas um outro aspecto a ser também considerado é a superação do princípio da imitação como fundamento comum às belas-artes. Se antes, a música pura não poderia possuir um lugar de destaque entre as demais artes, sendo vista apenas como um modo deficiente da música vocal, sendo criticada tanto por sua obscuridade e vagueza como por sua imitação imperfeita da natureza, teremos já a partir de meados do século XVIII uma mudança profunda de pensamento. Autores tão diversos como Chabanon, Adam Smith ou Reichardt chamarão a atenção para o fato de que a música poderia agradar por si mesma, e independentemente de uma imitação qualquer.

\footnotetext{
${ }^{510}$ Cf. CARVALHO, M. V. Razão e sentimento na comunicação musical. Lisboa: Relógio d'Água, 1999, p. 28. Também Charles Rosen (A Geração Romântica. S. Paulo: Edusp, 2000, p. 118) ressalta que "o que emancipou a música de sua dependência da corte e da igreja [...] foi a gradual proliferação do 'público de concerto' [...]. Esse desenvolvimento esteve acompanhado de uma mudança estética, uma nova concepção da obra de arte enquanto objeto independente, sem nenhuma outra função que a de induzir a contemplação e o prazer".

${ }^{511}$ Deve-se lembrar que não somente as sonatas propriamente ditas, mas também as sinfonias, trios, quartetos, etc., passam a ser escritos de acordo com os princípios da chamada forma-sonata.

${ }^{512}$ A música instrumental "iria ser considerada, por um bom tempo, o modelo ideal das outras formas de arte, uma espécie de absoluto, de fim, que só ilusoriamente poderia ser atingido pela pintura e pela poesia". Cf. ROSEN, C. A Geração Romântica. S. Paulo: Edusp, 2000, p. 118.
} 
Nos cursos sobre doutrina da arte ministrados em Berlin no ano de 1801, A. W. Schlegel censura a concepção - tal como defendida por Batteux, por exemplo - de que a arte deveria imitar a "bela natureza". August Schlegel argumenta que não haveria muito sentido em se fazer uma imitação meramente passiva, uma cópia ou repetição daquilo que está disponível na natureza. ${ }^{513}$ Temos a partir de agora uma mudança na concepção de imitação: a natureza deverá ser tomada "não como uma massa de produtos", mas sim em seu aspecto criador, "como aquilo mesmo que produz", e a imitação, por sua vez, passará a ser considerada não como a cópia do aspecto exterior da natureza, mas pelo contrário, a arte deverá ser, tal como a natureza, uma "criadora autônoma, [...] organizada e organizadora", configurando, dessa maneira, obras vivas e acabadas em si mesmas. ${ }^{514}$

Ora, se as artes a partir de agora devem ser criadoras, tal como a natureza, abre-se um espaço para que a música instrumental pura adquira uma certa importância estética. De fato, a partir do momento em que a arte não mais necessita imitar o aspecto meramente exterior da natureza, em que ela deixa de se pautar por regras e normas préestabelecidas e codificadas, tornando-se arte do gênio, é que a música instrumental pura (considerada como linguagem original, que não imita um objeto exterior, mas que cria a partir de si mesma) poderá ser tomada como a arte que mais se aproxima desse ideal. ${ }^{515}$ Aliás, não é à toa que

${ }^{513}$ SCHLEGEL, A. W. Die Kunstlehre. Hg. E. Lohner. Stuttgart: W. Kohlhammer, 1963, p. 84.

${ }^{514}$ SCHLEGEL, A. W. Die Kunstlehre, p. 91. A influência de Moritz aqui é clara, e o próprio $A$. Schlegel é o primeiro a reconhecê-la ao tecer inúmeros elogios à obra daquele autor, e em especial ao seu texto "Über die bildende Nachahmung des Schönen" (1788), no qual, como vimos anteriormente, o belo é descrito como algo que é acabado em si mesmo [das in sich Vollendete], e que pode ser apreendido como um todo por intermédio de nossa imaginação.

${ }^{515}$ Cf. Por exemplo o artigo de Michaelis Über das Idealische der Tonkunst (1808). 
se passa a considerar que a figura do compositor é a que melhor corporifica as características do verdadeiro gênio artístico. ${ }^{516}$

Como apontamos na introdução a este trabalho, também os escritos de Kant ocupam um papel fundamental para a reconstrução desse processo de autonomização da música instrumental pura, principalmente no que concerne ao problema da subjetividade, à questão do gênio como produtor de idéias estéticas, e ao problema do incondicionado. Partindo dos problemas deixados por Kant, é no Sistema do Idealismo Transcendental de Schelling (1800), que a arte adquire uma importância suprema enquanto órganon e documento de toda a filosofia.

Embora não se possa determinar com absoluta precisão a recepção da Crítica do Juízo no pensamento de Wackenroder e de Tieck, parecenos pouco provável que os dois amigos não tivessem tomado conhecimento da mesma. Em todo caso, deve-se lembrar a proximidade que tiveram com o compositor J. F. Reichardt, o qual havia sido aluno de Kant em Königsberg e manteve contato com o mesmo ao longo de sua vida. ${ }^{517}$ Além de ter publicado e comentado excertos da Crítica do Juízoespecialmente os trechos dedicados à teoria do gênio - em sua Musikalisches Kunstmagazin (aos quais certamente Wackenroder e Tieck tiveram acesso), Reichardt pretendia adaptar os ensinamentos de Kant à arte da música, coisa que, no entanto, nunca ocorreu. ${ }^{518}$

\footnotetext{
${ }^{516}$ Os dois principais exemplos são, sem dúvida, os personagens de Joseph Berglinger (criado por Wackenroder e Tieck) e do Kapellmeister Kreisler (criado por E. T. A. Hoffmann).

${ }^{517}$ Cf. Carta de Reichardt a Kant de 28.Agosto. 1790 bem como a resposta de Kant de 15.Out.1790.

${ }^{518}$ No segundo volume da Musikalisches Kunstmagazin de 1791 Reichardt publica alguns excertos da Crítica do Juízo $(\S 60, \S 44)$ e anuncia sua intenção de escrever a obra acima citada.
} 
No caso de C. F. Michaelis, por outro lado, a filiação kantiana é explícita. Se é certo que ele nunca se distinguiu por sua originalidade filosófica e atuou, talvez, mais no sentido de divulgar e popularizar a filosofia kantiana, podemos afirmar que sua grande contribuição para a estética musical reside no fato dele utilizar as ferramentas teóricas kantianas para ir além de Kant, notadamente ao aplicar à música pura os conceitos de imaginação e de idéia estética expostos na Crítica do Juízo.

Ao buscar fundamentar o estatuto da música como arte bela, Michaelis pode ser considerado um dos principais elos de ligação entre a reflexão kantiana e a reflexão romântica sobre a música. Mas se Michaelis preocupou-se principalmente em conferir um estatuto de arte bela (e não meramente agradável) à música, temos que investigar também a outra face da moeda: a música como veículo do sublime.

Mas aqui talvez seja conveniente sair do âmbito da história puramente abstrata das idéias, para tentar examinar também uma outra questão que diz respeito ao lugar da obra de arte musical para a constituição dessa estética.

Em diversos estudos, o musicólogo Carl Dahlhaus chamou a atenção para o fato de que a estética musical não deve ser vista exclusivamente como mero reflexo da prática composicional, mas também, em certo sentido, como um dos momentos constitutivos dessa prática, influenciando composição, interpretação e recepção da música. ${ }^{519}$ Assim, pode-se explicar como é possível o surgimento de uma estética musical romântica já na última década do século XVIII (com as obras de Wackenroder e Tieck) independente de uma prática musical romântica, a qual só iria aparecer algumas décadas mais tarde. Na verdade, poder-seia mesmo afirmar que a estética romântica precede a prática musical, de modo que a análise das mudanças ocorridas na filosofia e na literatura

${ }^{519}$ Cf. DAHLHAUS, C. Die Idee der absoluten Musik. Basel: Bärenreiter, 1994, p. 66ss. 
seja talvez mais importante para a compreensão das origens dessa estética do que a análise de exemplos da produção musical em voga à época. $^{520}$ Mas se é certo o fato de não haver uma música que correspondesse plenamente à metafísica da arte desenvolvida por Wackenroder e Tieck ${ }^{521}$, não podemos deixar de notar, por outro lado a importância que a música instrumental - e sobretudo a sinfonia - irá adquirir como veículo do sublime. Isso fica bastante claro na atividade crítico-musical de E. T. A. Hoffmann.

Diferentemente de Wackenroder e Tieck, que não nomeiam nenhum compositor $^{522}$ ou obra em seus textos, Hoffmann faz sua estréia como escritor com um texto que faz menção direta ao compositor C. W. Gluck.

Além disso, em sua célebre recensão publicada em 1810 acerca da Quinta Sinfonia de Beethoven ${ }^{523}$, ele irá citar também Haydn e Mozart

520 "Porém, mais desconcertante do que a simultaneidade de tendências e tradições heterogêneas é o paradoxo de que, por volta de 1800, não havia uma estética musical clássica que correspondesse à música clássica de Haydn e Mozart e nem uma música romântica, que correspondesse à estética romântica de Wackenroder e Tieck. Havia um abismo entre reflexão e praxis. [...] nesse sentido, a estética musical romântica de Wackenroder e Tieck permaneceu abstrata, como se ela devesse se referir à música sem mais - e não a um tipo determinado de música; somente em retrospectiva é que ela apareceu como antecipação literária do romantismo musical, desde 1814". Cf. DAHLHAUS, C. Klassische und romantische Musikästhetik . Laaber: Laaber-Verl, 1988, p. 86-7)

${ }^{521}$ Pode-se afirmar que essa teoria prepara o terreno para uma música que se poderá dizer propriamente "romântica" que só apareceria de fato algumas décadas depois, tendo em Schumann, por exemplo, um de seus principais representantes.

${ }^{522} \mathrm{Um}$ aspecto que chama a atenção nos textos de Wackenroder é que ele, ao tratar da arte da pintura, nomeia inúmeros artistas (todos do Renascimento italiano ou alemão), mas ao tratar da música ele opta por criar um personagem fictício - Joseph Berglinger que antecipará temas que serão tratados também por Hoffmann, alguns anos mais tarde. Somente Tieck, em seu texto Sinfonias constitui uma exceção, ao nomear uma composição de Reichardt (Abertura Macbeth). Foi somente mais tarde, no Phantasus, que Tieck cita nominalmente alguns compositores (Haydn, Mozart, Beethoven, etc). A semelhança entre algumas formulações suas e as de Hoffmann permitem supor que Tieck tivesse grande familiaridade com as obras deste. Cf. TIECK, L. Phantasus: eine Sammlung von Märchen, Erzählungen und Schauspielen. 2. Bd. Berlin: G. Reimer, 1845, p. 77: "aquela profunda paixão da alma [Leidenschaft der Seele], aquela luta de todas as forças em um anseio inefável [unaussprechlicher Sehnsucht], mesmo aquele terror [Grauen] e horror [Entsetzen] não permaneram alheios a ela [à música]".

${ }^{523}$ Essa recensão, juntamente com a crítica sobre os Trios op. 70 (também de Beethoven) foram utilizados como base e reaproveitados por Hoffmann quando da 
como exemplos de compositores "genuinamente românticos". Mas como compreender aqui o sentido do termo romântico? Certamente não no sentido em que o termo é geralmente compreendido nos manuais de história da música. Na verdade, como mostramos no capítulo anterior, ao denominar Haydn, Mozart e Beethoven como compositores "genuinamente românticos", Hoffmann refere-se ao contexto filosófico da época e às dicussões presentes na obra de Schiller, de F. Schlegel e, sobretudo, de Jean-Paul.

Há ainda a questão das análises musicais empreendidas por Hoffmann em suas críticas musicais. Ora, se nas recensões publicadas nos jornais de sua época, Hoffmann recorre à análise minuciosa das obras (como, por exemplo, da Quinta Sinfonia ou dos Trios op. 70 de Beethoven), é porque esta é, talvez, a única maneira de mostrar em que aspectos precisos tais obras incorporam o ideal romântico da música como veículo privilegiado de expressão do sublime, como uma linguagem elevada, capaz de exprimir o inefável. Aliás, deve-se ressaltar o fato de que não é com a postura do anatomista que Hoffmann aborda sua tarefa crítico-analítica. ${ }^{524}$ Pelo contrário: é justamente a análise técnica que Ihe possibilitará ressaltar a organicidade das composições, a maneira como elas se desenvolvem a partir de um tema simples - mas que estrutura a peça toda - em seus mais ínfimos aspectos: rítmicos, melódicos e harmônicos. Sua postura como analista se distancia fundamentalmente

publicação de sua Kreisleriana (mais especificamente no capítulo intitulado "Beethovens Instrumentalmusik").

${ }^{524}$ No artigo "Zufällige Gedanken bei dem Erscheinen dieser Blätter", publicado pela primeira vez no Allgemeine Zeitung für Musik und Musikliteratur (Out./1820) Hoffmann condena o crítico-anatomista. Dirigindo-se ao compositor, ele escreve: "tu reencontrarás tua obra, não sobre uma mesa de anatomia sob as mãos assassinas de um dissecador bárbaro, mas em pé, diante um espírito que é teu amigo, que lança um olhar agudo sobre ela e, ao contrário daquele que a teria cortado impiedosamente em pedaços, anuncia em palavras tudo o que nela descobre, o maravilhoso edifício em seu todo e com todas as suas complexidades". Cf. HOFFMANN, E.T.A. Schriften zur Musik, p. 34344. 
daquela figura do pedante "juiz de arte" [Kunstrichter], ávido em apontar as infrações às regras de harmonia, os pretensos erros de encadeamento, as oitavas ocultas e que, ao analisar uma obra, acaba justamente por destruí-la. Sua atitude como crítico é inseparável de sus experiência como compositor. É como um artista que Hoffmann tentará compreender as intenções que estão por detrás da obra. Contrariamente à postura arrogante do "Kunstrichter", Hoffmann aborda as obras com a consciência de que "uma certa liberdade de espírito" - sempre unida à mais profunda reflexão [Besonnenheit] - é "própria ao grande gênio". 525

É preciso deixar de lado os pré-juízos do senso comum, se pretendemos fazer justiça aos textos desses escritores. Longe de serem meros diletantes, os autores do Primeiro Romantismo alemão estavam profundamente inteirados das principais discussões filosóficas e estéticas de seu tempo, e muitos aspectos de suas obras podem ser vistos como tentativas de dar conta dos problemas postos pelas filosofias de Kant e Fichte. Seria uma atitude superficial ler as obras desses autores como mera "exaltação" [Schwärmerei]. Pelo contrário, seu pensamento é dotado de uma face inovadora e moderna, possuidora de enorme riqueza e fecundidade. Estetas e filósofos de orientações tão distintas como Hanslick e Schopenhauer podem ser considerados como tributários de muitos aspectos da reflexão romântica. Mas não foi apenas no campo filosófico, crítico e literário que essa reflexão deixou suas marcas: grande

\footnotetext{
${ }^{525}$ HOFFMANN, E.T.A. Schriften zur Musik, p. 346. Também Diderot, no Discurso sobre a poesia dramática expressou um ponto de vista semelhante: "Ó fabricadores de regras gerais, como sois pouco versados em arte, como tendes pouco daquele gênio que produziu os modelos sobre os quais estabelecestes estas regras, gênio que é soberano para infringi-las quando bem entender!". (DIDEROT, D. Discurso sobre a poesia dramática. Trad. L. F. Franklin de Matos. São Paulo: Brasiliense, 1986, p. 74).
} 
parte da produção musical posterior também foi influenciada pelo pensamento filosófico e literário romântico.

Um exemplo privilegiado disto pode ser encontrado nas obras - bem como nos escritos de crítica musical - do compositor alemão Robert Schumann (1810-1856). Tendo sido um ávido e atento leitor de Jean-Paul e Hoffmann, sabe-se que tais leituras estão impregnadas em algumas de suas principais obras. Em Papillons Op. 2 temos uma espécie de releitura de Flegeljahre, de Jean Paul, e em diversas peças ele faz alusões a obras de E. T. A. Hoffmann (Fantasiestücke, Nachtstücke, dentre outras, sendo a mais célebre delas o ciclo de oito peças para piano intitulado Kreisleriana Op. 16).

Mas para além do aspecto meramente superficial dos títulos ou da tentativa de se encontrar alguma intenção programática em suas obras, uma abordagem mais rica seria talvez a de tentar identificar em Schumann o emprego de alguns procedimentos caros aos românticos, como o uso de formas fragmentárias, por exemplo. Outra característica que chama a atenção em Schumann, e que mereceria ser investigada com profundidade, é o emprego - inédito até então - de longos poslúdios puramente instrumentais como conclusão de dois de seus mais importantes ciclos de canções, a saber: Frauenliebe und Leben Op. 42 (sobre poemas de Chamisso) e Dichterliebe Op. 48 (sobre poemas de Heine). Ao entregar a última palavra ao instrumento, Schumann parece realizar musicalmente aquele ideal romântico da música como linguagem do inefável: "quando as palavras já não bastam, a música pura expressa aquilo que as palavras não conseguiriam exprimir". 


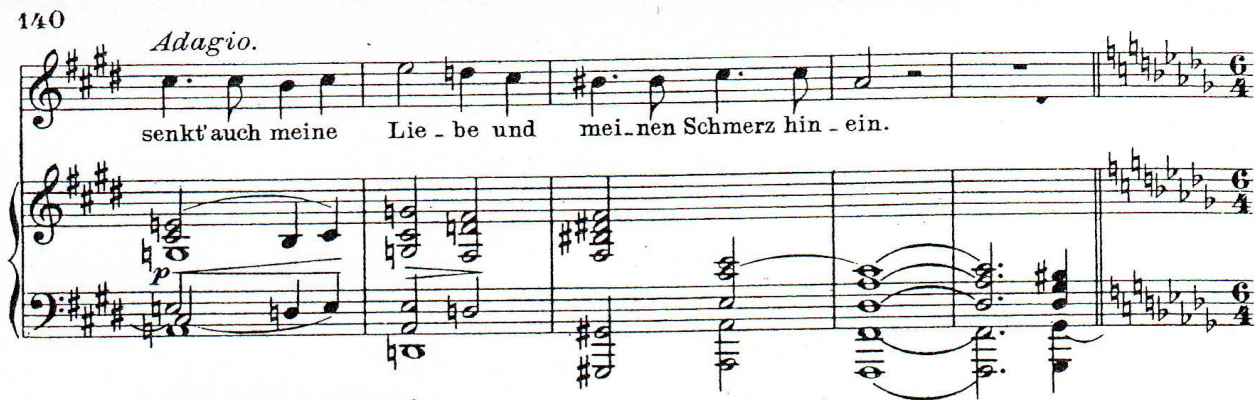

Andante espressivo.

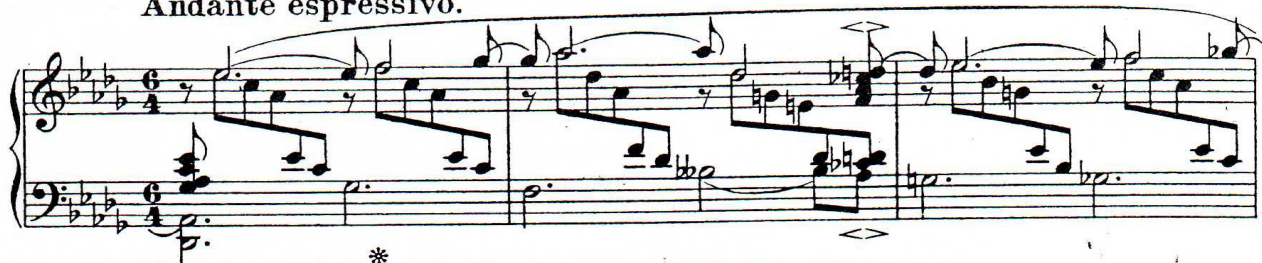

3ed.
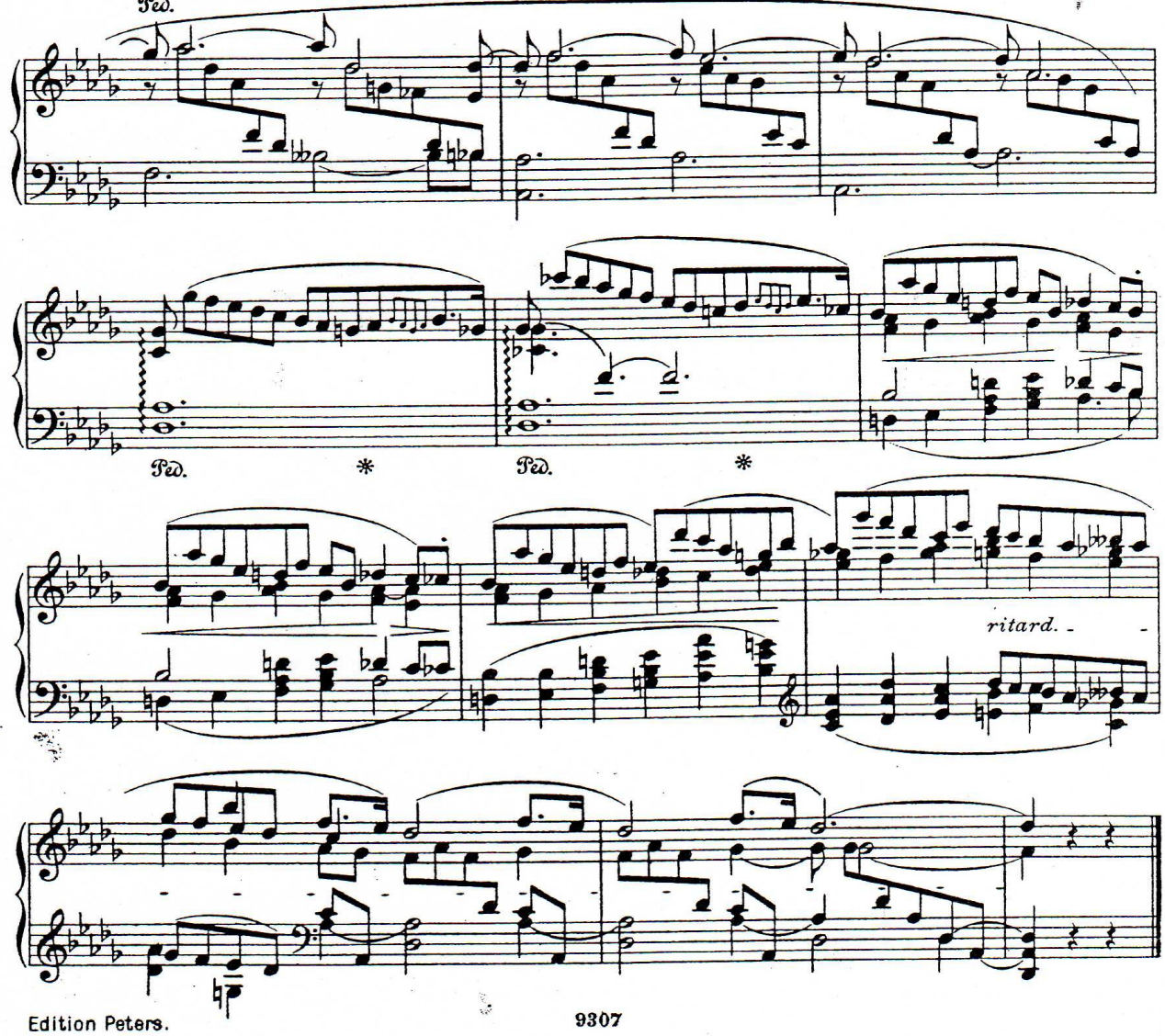

Ilustração Musical Nr. 6: Trecho final da última canção do ciclo "Dichterliebe", Op. 48 de Robert Schumann. 
APENDICES : 
Apêndice 1: SULZER, J. G. Allgemeine Theorie der schönen Künste (2. Teil). Leipzig: Weidmann, 1774.

//1121//

Sinfonia (Música): Peça instrumental para múltiplas vozes, que é usada no lugar das obsoletas [abgekommenen] Aberturas [Ouvertüren]. A dificuldade de se executar bem uma Abertura, e a dificuldade maior ainda de se fazer uma boa Abertura, deu origem à forma mais fácil da Sinfonia que, a princípio [consistia] em uma ou algumas peças fugadas, que alternavam com peças de dança de diferentes tipos, e eram geralmente denominadas Partitas [Parties]. A Abertura ainda se conservou antes de grandes peças sacras e Óperas; e utilizavam-se as Partitas somente na música de câmara: contudo, [como] essas peças de dança sem dança cansavam logo, por fim passou-se a se contentar com um ou dois Allegros fugatos ou não-fugatos, que se alternavam com um lento Andante ou Largo. Esse gênero foi denominado Sinfonia, e foi introduzido tanto na música de câmara como antes de Óperas e músicas de igreja, onde ela ainda está em uso. Os instrumentos que pertencem à Sinfonia são: violinos, violas e baixos; //1122// cada voz é dobrada [stark besetzt]. Para o preenchimento [Ausfüllen] ou para o reforço [Verstärkung] podemse acrescentar ainda trompas, oboés e flautas.

Pode-se comparar a Sinfonia com um coro instrumental, assim como a Sonata com uma cantata instrumental. Nesta última, uma vez que a voz principal não é dobrada [nur einfach besetzt], a melodia da voz principal pode ser feita de maneira a tolerar ornamentos, e frequentemente até os exige. Na Sinfonia, pelo contrário, onde cada voz é dobrada [mehr wie 
einfach besetzt], o canto deve conter a mais alta ênfase nas notas já prescritas e nenhuma voz pode tolerar o menor ornamento ou coloratura. Da mesma forma, como ela não é uma peça de exercício [Übungsstück] como a Sonata, mas deve ser lida à primeira vista, não pode aparecer [na Sinfonia] nenhuma dificuldade que não possa ser logo superada e executada de maneira clara por muitos [instrumentistas].

A Sinfonia é especialmente apropriada para a expressão do grandioso [Großen], do solene [Feyerlichen] e sublime [Erhaben]. Sua finalidade última [Endzweck] é preparar o ouvinte para uma música importante ou, em um concerto de câmara, oferecer toda a magnificência [Pracht] da música instrumental. Para que ela atinja essa finalidade com completa suficiência [Genüge], e seja uma parte integrante da Ópera ou música de igreja que ela precede, ela precisa, além da expressão do grandioso e solene, possuir ainda um caráter [Charakter] que coloque 0 ouvinte no estado de ânimo [Gemüthsverfassung] que a peça seguinte exige no todo, e se diferenciar através de seu estilo [Schreibart], conforme se destine à Igreja ou ao Teatro.

A Sinfonia que constitui um todo que se mantém por si [ein für sich bestehendes Ganze], que não tem como meta nenhuma música seguinte, só atinge sua finalidade última através de uma escrita sonora [volltönig], brilhante e ardente [feurig]. Os Allegros das melhores Sinfonias de Câmara contêm pensamentos grandiosos e audazes [kühne und großen Gedanken], manejo livre das frases [Satz], aparente desordem da melodia e harmonia, ritmos de diferentes tipos fortemente marcados, robustas melodias no baixo e uníssonos, vozes centrais concertantes, imitações livres, freqüentemente um tema que é tratado à maneira da fuga, passagens súbitas, digressões de um tom para outro, que surpreendem 
mais fortemente quanto mais fraco é o encadeamento, fortes matizes do Forte e Piano, e especialmente do Crescendo, o qual, quando é colocado ao mesmo tempo que uma melodia ascendente e de expressão que se intensifica, produz o maior efeito [Wirkung]. Além disso, há ainda a arte de combinar todas as vozes entre si de tal maneira, que ao soarem conjuntamente, só se ouve uma melodia, que não precisa de acompanhamento, mas para a qual cada voz contribui com a sua parte. Um tal Allegro na Sinfonia é o [mesmo] que uma Ode Pindárica é na Poesia; tal como esta, ele eleva e comove profundamente a alma do ouvinte, e requer o mesmo espírito, a mesma imaginação sublime e o mesmo conhecimento da arte, para ser bem-sucedido ali. Os Allegros nas Sinfonias do holandês Vanmaldere ${ }^{526}$, que podem ser considerados como modelos desse gênero de música instrumental, possuem todas as características anteriormente mencionadas e testemunham a grandeza de seu autor, cuja morte prematura privou a Arte de ainda muitas obrasprimas desse tipo.

O Andante ou Largo entre o primeiro e o último Allegro não possui na verdade um caráter não determinado, mas é freqüentemente de uma expressão agradável [angenehm], ou patética, ou triste; contudo, ele precisa ter um estilo apropriado à dignidade da Sinfonia, e não consistir em meras trivialidades [Tändelei], como parece tornar-se moda, pois isso seria mais conveniente numa Sonata, ou poderiam ainda ter um bom lugar em Sinfonias que precedem Operetas cômicas.

As Sinfonias de Ópera adotam mais ou menos da característica da Sinfonia de Câmara, conforme ela se adapte ao caráter da Ópera a ser

\footnotetext{
${ }^{526}$ Pieter van Maldere (1729-1768), compositor holandês célebre por suas inovações na escrita sinfônica [N. T.].
} 
representada. Contudo, parece que elas toleram menos digressões e não podem ser muito elaboradas, pois o ouvinte está mais atento para o que deve seguir do que para a Sinfonia mesma. Como a maioria de nossas grandes Óperas parece possuir o mesmo caráter e ter como base um deslumbramento dos ouvidos e dos olhos, a Sinfonia já faz seu efeito se ela soa agradavelmente. Pelo menos as Sinfonias dos italianos não possuem nunca uma outra característica: os instrumentos fazem ruídos nos Allegros sobre uma linha de baixo repetitiva [Trommelbass] e [apenas] três acordes; nos Andantinos, [os instrumentos] executam trivialidades [Tändeln], sem força e expressão; mas [também] nenhum ouvinte na Itália presta atenção à Sinfonia. [Carl Heinrich] Graun trouxe muito mais //1123// arte e caráter a suas Sinfonias de Óperas. Contudo, faltava à sua alma terna o fogo necessário para isso. $O$ belo canto, que nunca o abandonou, por mais digno de valor que seja, é de um efeito apenas opaco em toda Sinfonia. Acredita-se ouvir uma Ária de Ópera executada por instrumentos. Nesse campo, Graun seria superado por seu irmão, o falecido "mestre de concertos" [Concertmeister], que em suas Sinfonias de Câmara capturou o verdadeiro espírito da Sinfonia. Também [Johann Adolph] Hasse o superou nisso, embora suas Sinfonias de Ópera possuam também muito dessa qualidade lírica.

Em suas Sinfonias que precedem as Operetas, os franceses procuram alternar trivialidades com pensamentos sublimes. Mas toda a sua sublimidade degenera em empolamento [Schwulst]. Para se convencer disso só é preciso ouvir ou ver em partitura a melhor Sinfonia francesa. Como as Operetas em geral possuem mais [elementos] característicos do que as grandes óperas, não é obrigatório que uma peça precise começar sempre com uma Sinfonia. Muitas Operetas podem possuir um caráter que absolutamente não é apropriado à grandeza da 
Sinfonia. Aqui seria uma oportunidade de se inventar novas formas, que fossem adequadas a cada peça, e que se poderia dar o nome geral de Introdução [Introduction], para que elas não fossem confundidas com a Sinfonia, a qual, na realidade, deve possuir sempre a pompa e a grandiosidade da música instrumental como finalidade última.

A Sinfonia de Igreja distingue-se das restantes principalmente através do estilo sério. Freqüentemente ela consite somente em uma única peça. Ela não tolera digressões ou desordens nas progressões [Fortschreitungen] melódicas e harmônicas, tal como a Sinfonia de Câmara, e prossegue em passos fixos, rápidos ou lentos, segundo a natureza da expressão da peça de igreja, observando estritamente as regras de composição [Regeln des Satzes]. Ao invés do pomposo, ela possui freqüentemente como finalidade última uma quieta sublimidade [stille Erhabenheit], e é muito compatível com uma fuga patética e bemelaborada.

\section{$/ / 1094 / /$}

Sonata (Música): Peça instrumental de duas, três ou quatro partes consecutivas de caráter distinto, que possui somente uma ou diversas vozes principais [Hauptstimmen], as quais, contudo, não são dobradas [einfach besetzt]: dependendo se ela consiste de uma ou mais vozes principais concertantes entre si, a sonata é denominada a solo, a due, a tre, etc.

Em nenhuma outra forma além da sonata, a música instrumental tem possibilidade mais cômoda de mostrar a sua capacidade de descrever sentimentos [Empfindungen] sem [o uso de] palavras. A Sinfonia e a Abertura possuem um caráter [Charakter] determinado de maneira mais 
precisa; a forma de um Concerto parece ter mais como propósito dar a um hábil instrumentista a oportunidade de ser ouvido acompanhado por diversos instrumentos, do que ser utilizado para a descrição das paixões. Além dessas [formas] e das danças, que também possuem o seu próprio caráter, há ainda na música instrumental somente a forma Sonata, que assume todo caráter e toda expressão [Ausdruck]. O compositor pode, numa sonata, ter como propósito exprimir um monólogo em sons da tristeza, do lamento, da dor ou da ternura, do prazer e da alegria; ou manter uma conversa sentimental [empfindsam] meramente em sons apaixonados, sob caráteres iguais ou contrastantes entre si; ou meramente descrever movimentos de ânimo [Gemütsbewegungen] impetuosos, tempestuosos ou contrastantes, ou leves e suaves, fluentes [e] deliciosos. Porém //1095// são pouquíssimos os compositores que possuem esses propósitos ao elaborar sonatas, e menos ainda os italianos e aqueles que se formam segundo eles: um ruído [composto] de sons que se seguem arbitrariamente, sem outra intenção que não seja divertir o ouvido insensível; passagens súbitas e fantásticas do alegre para o lamentoso, do patético para o trivial [Tändelnden], sem que se compreenda o que o compositor deseja com isso, caracterizam as sonatas dos italianos de hoje, e se a execução das mesmas ocupa a imaginação de algumas cabeças febris, o coração e os sentimentos de todo ouvinte de gosto ou conhecimento permanece, contudo, em completo descanso.

A possibilidade de dotar as sonatas de caráter e expressão é provada por uma grande quantidade de sonatas fáceis e difíceis para teclado de nosso Bach de Hamburgo [C.P.E. Bach]. A maioria delas é tão eloqüente, que se acredita escutar não sons, mas uma linguagem compreensível [verständliche Sprache], que põe em movimento e 
entretém nossa imaginação [Einbildung] e sentimentos [Empfindungen]. É incontestável que para se fazer tais sonatas se requer muito gênio, ciência e uma sensibilidade [Empfindbarkeit] especialmente lírica e delicada. Mas elas exigem também uma execução plena de sentimentos, que nenhum teuto-italiano é capaz de encontrar, mas que freqüentemente é encontrada por crianças que se acostumam com tais sonatas por algum tempo. As sonatas desse mesmo compositor [C.P.E. Bach], com duas vozes principais concertantes, e que são acompanhadas por um baixo, são verdadeiras conversas em sons [Tongespräche] apaixonadas; e quem acredita não sentir ou ouvir isso nelas, deveria levar em conta que elas não são sempre executadas como deveriam. Dentre essas, uma ${ }^{527}$, que mantém uma tal conversa entre um Melancholicus e um Sanguineus, destaca-se de maneira tão excelente, e é tão plena de inventividade e caráter, que se pode considerá-la uma obra-mestra da boa música instrumental. Os compositores iniciantes que desejam ser bem-sucedidos [na escrita de] sonatas devem tomar para si como modelos as obras desse gênero de [C.P.E.] Bach e outras similares a estas.

Para instrumentistas, as sonatas são os melhores e mais habituais exercícios [Uebungen]; há também uma grande quantidade deles, fáceis e difíceis, para todos os instrumentos. Na música de câmara eles ocupam a primeira posição depois das peças vocais e, uma vez que não há dobramentos de vozes [einfach besetzt], podem ser executados sem maiores dificuldades mesmo nos menores conjuntos musicais. Um único músico pode, com uma sonata para teclado, entreter uma platéia inteira freqüentemente melhor e com maior efeito do que o maior dos concertos.

${ }^{527}$ Trata-se do Trio-Sonata em dó menor H. 579. 
No artigo Trio falaremos de maneira mais detalhada das sonatas com duas vozes principais [Hauptstimmen], com baixo meramente acompanhador ou concertante. 
Apêndice 2: $\mathrm{KOCH}, \mathrm{H}$. C. Versuch einer Anleitung zur Composition (2. Teil). Leipzig: Adam Fr. Böhme, 1787.

$/ / 15 / /$

\author{
Primeira Seção \\ Do propósito, da constituição interna \\ e, especialmente, do modo pelo qual se origina \\ uma peça musical.
}

A música é uma arte bela, que tem como propósito despertar em nós sentimentos nobres [edle Empfindungen].

Os sentimentos encontram-se como que adormecidos na natureza do homem e só são despertados através de certos motivos naturais; por exemplo, a posse de algo que representamos como bom [Gut], gera prazer [Vergnügen], e a representação de que um mal [Übel] existente possa nos atingir, desperta temor [Furcht] em nós. [...]

//16// [...] Despertar sentimentos é, pois, o verdadeiro propósito da música, e este é, ao mesmo tempo, o ponto de vista a partir do qual pretendemos, a seguir, examinar mais de perto a parte mais excelente dessa arte, a saber, a composição, e os produtos dela resultantes. [...]

//29// [...] A música fala, em si e por si mesma, a linguagem dos sentimentos [Sprache der Empfindungen], ela não tem //30// necessidade de se expressar por sinais pantomímicos, nem por conceitos e imagens através de palavras; ela atua sobre nosso coração de maneira imediata, e produz tanto sentimentos agradáveis quanto desagradáveis. Contudo, ela 
não é capaz de nos tornar conhecidas as causas pelas quais ela suscita este ou aquele sentimento, pelas quais somos conduzidos de um sentimento para o outro; ela não pode nos tornar apreensível a figura daquele bem, cuja fruição nos dá prazer, nem a figura do mal, que suscita temor. [...] A situação é totalmente diferente quando a música está unida à poesia ou à dança. A poesia não apenas determina da maneira mais exata aqueles sentimentos cuja expressão é similar entre si, //31// colocando o compositor fora do perigo de ser entendido erroneamente; mas também nos torna conhecidas as causas pelas quais este ou aquele sentimento é despertado, pelas quais somos conduzidos de um sentimento para o outro. Ela atua, portanto, ao mesmo tempo, sobre as forças mais elevadas da alma, ela permite que comparemos causa e efeito, ação e sentimento, e isso tem como conseqüência, que não apenas o nosso coração se sente interessado por esses sentimentos, mas também que esses sentimentos disponíveis para um fim nos provoquem resoluções que possam contribuir para o enobrecimento de nosso coração. [...] uma vez que, através da poesia, tanto o material [Stoff] como o propósito [Absicht] do todo, tornam-se claros, ela [a música unida à poesia] pode passar de um sentimento para outro, e utilizá-los para a finalidade comum. O prazer que a música provoca, quando unida à poesia, não é mais um sentimento sem relações, sem causa e sem finalidade última [Endzweck]; não! Nós conhecemos //32// as fontes a partir das quais [esse prazer] jorra [...]. A poesia suscita os sentimentos através de conceitos e imagens, enquanto a música (simultaneamente a esses sentimentos despertados pelos conceitos e imagens) penetra imediatamente no coração, e ambas as artes unidas provocam agora aquele elevado grau de sentimento e do prazer daí resultante, e que uma dessas artes por si só não conseguiria produzir. 
Em união com a poesia, portanto, a música poderá ousar despertar quase todos os tipos de sentimentos agradáveis e desagradáveis, e entreter com suas diversas modificações. Essas duas artes não poderão atuar no mesmo grau em todos os sentimentos a serem despertados. Aqui e ali a música terá que deixar para a poesia o grau mais forte do efeito, ela irá apenas apoiar, e poderá atuar sobre o coração dos ouvintes apenas com débeis forças.

//33// [...] [mas a música], com sua força característica, freqüentemente terá a oportunidade de produzir no mais alto grau as diferentes paixões [Leidenschaften], para as quais a poesia não possui nenhum sinal [Zeichen] e que a linguagem não possui mais nenhuma expressão. [...] A partir disso tudo vemos que, na realidade, é só na união com a poesia que a música pode atingir seu propósito mais elevado e sua finalidade última, e que seu efeito é extremamente desvantajoso quando a separamos da poesia. [...]

//34// Acabamos de ver que, quando a poesia está unida à música, esta pode atuar de maneira totalmente determinada [bestimmt] sobre os ouvintes, pois os conceitos e imagens contidos na poesia não expõem 0 compositor tão facilmente ao perigo de ser mal-entendido. [...] Jamais ele [o compositor] será capaz, somente por meio da música, de produzir uma distinção suficientemente determinada, por exemplo, entre //35// temor [Furcht] e compaixão [Mitleid], sem se expor ao perigo de ser compreendido erroneamente por todos os seus ouvintes. Vê-se, pois, que a música, por si só, quando deve despertar sentimentos, possui limites muito mais estreitos do que quando ela está unida à poesia. [...] É fácil de perceber o quanto a música sai perdendo em seu efeito quando se separa da poesia; por outro lado, é mais difícil de se compreender //36// por que num concerto, que freqüentemente é organizado com tanta pompa, fica- 
se satisfeito com o mero efeito da música instrumental, se esse prazer poderia ser muito mais intensificado e enobrecido através da união com a poesia! 
Apêndice 3: MICHAELIS, C. F. "Noch einige Bemerkungen über den Rang der Tonkunst unter den schönen Künsten". In: $A m Z$ 6, Nr. 46, (15.08.1804).

\section{Mais algumas observações sobre a posição da música dentre as belas-artes (Como adição e definição mais próxima de um ensaio anterior)}

//765//

Herder observa, com toda a razão, em seu livro Kalligone $\left(2^{\mathrm{a}}\right.$. parte do ensaio sobre a música, p. 145-181), que a querela acerca do valor das artes entre si ou em consideração à natureza do homem, seria sempre vazia e nula. "O espaço não pode [ser] tempo, o tempo não pode [ser] espaço, o visível não pode [ser] audível, e este não pode se tornar visível; nenhum deles se atribui um âmbito alheio, e domina em seu [âmbito], mas quanto mais poderoso [é seu domínio em seu âmbito próprio], tanto mais certo e nobre [ele é]. É justamente porque as artes se excluem mutuamente com relação ao seu meio [Medium], que elas ganham o seu reino; em parte alguma unidas, a não ser na natureza do homem, no centro de nosso sentimento [Empfindung]".

Não obstante, as comparações entre as belas-artes e as tentativas de mostrar os seus privilégios característicos entre si são instrutivas e muito naturais à faculdade de julgar. Apesar de Herder declarar como nula a disputa sobre o valor das artes entre si, logo a seguir ele concede à música um privilégio que foi subestimado por muito tempo, ou que parece não ter sido claramente admitido, e que escapou até mesmo à perspicácia de Kant. "Quanto à eficácia interna [innerer Wirksamkeit], a música (assim lemos em Kalligone) supera toda arte que se prende ao visível, assim como o corpo //766// [é superado] pelo espírito: pois ela é espírito, 
aparentado com a maior força interna da natureza: o movimento. O que não pode se tornar visível ao homem, o mundo do invisível [Unsichtbar], torna-se comunicável a ele [através] da música. Todo instante dessa arte é transitório [...] No vir e no fugir, no devir e no que se tornou é que está a força vencedora do som e do sentimento. Em compensação, toda arte do ver, que se prende a objetos e gestos limitados, a cores naturais [Lokalfarbe], apesar de mostrar tudo de uma só vez, é, contudo, apreendida apenas de maneira lenta".

Quanto mais uma das belas-artes pressupõe uma predisposição [Empfänglichkeit] mais perfeita para a Forma pura [reine Form] da beleza, tanto mais precisa é a sua determinação [Bestimmtheit] na expressão estética do belo, do sublime e do moral; quanto mais abrangente, quanto mais extensa, quanto mais íntima em suas representações, tanto mais cultivadora [kultivirender] para a humanidade ela é, e tem que ser reconhecida como mais nobre e digna de apreço. É, sem dúvida, por isso que Kant (na sua Crítica do Juízo) concede a primeira posição dentre as artes à poesia [Dichtkunst], a qual, com sua energia sem reivindicações [anspruchlosen Energie], tem a precedência mesmo diante da eloqüência, que é menos satisfatória, já que se afasta mais do âmbito da pura beleza, principalmente por ter a utilidade [Nützlichkeit] como intenção principal. A arte plástica [bildende Kunst] é mais limitada, tendo em vista a abrangência ampla e o //767// conteúdo profundo [tiefen Gehaltes] com os quais a poesia parece não ser alcançada por nenhuma outra arte: por isso ela ocupa a próxima posição, logo após as artes elocutivas [redenden Künsten]; e se nós, como é justo, excluímos das belas-artes puras a mera retórica [Redekunst]; então, segundo seu valor, [a arte plástica] vem logo em seguida à poesia. Porém, dentre as artes plásticas, novamente devido ao seu maior refinamento, extensão mais variada e conteúdo mais rico, a arte do desenho e a pintura terão a primazia diante da escultura, que é 
mais limitada devido à sua matéria [Stoff] e instrumentos [Werkzeuge]. Contudo, segundo a expressão estética, cada uma delas, no interior de seus limites, mantém um efeito e valor uniformes [gleichmässig]. A terceira posição, segundo Kant, é ocupada pela música, a qual (como the parece), proporciona o maior gozo [grössten Genuss], mas a menor cultura [wenigste Kultur], pois lida com meras sensações [Empfindungen], as quais conduzem apenas a Idéias indeterminadas de afetos; igualmente, segundo sua determinação e pureza de belas representações, ela vem após as demais artes, pois ela não pode impedir a mistura de estímulos agradáveis e desagradáveis dos sentidos [Sinnenreize] tanto como as outras artes [o podem fazer].

Essa última opinião foi constestada, com razão, pelos novos estetas. Não se pode negar o efeito fisiológico e medicinal da música. Ela age sobre os nervos, e elogia-se sua força tranqüilizadora ou estimulante. ${ }^{528}$ //768// Um temperamento sanguíneo também pode ser muito estimulado e obter prazer, especialmente mediante a música de dança. $\mathrm{O} \mathrm{Sr}$. $D$. Jenisch também tem bastante razão ao se expressar da seguinte maneira acerca do gosto de nossa época com relação à música (Geist und Charakter des achtzehnten Jahrhunderts. Berlin, 1801, na $1^{\mathrm{a}}$. Parte do $2^{\circ}$. vol.): [...] "A música [...] pode conduzir ao amolecimento [Verweichlichung]; contudo segundo sua natureza originária, ela é, como toda arte bela, promovedora da humanidade, e atua moderando e tranqüilizando nosso ser".

\footnotetext{
${ }^{528}$ A música (afirma o imortal J. A. P. Schulz em seus Gedanken über den Einfluss der Musik auf die Bildung eines Volks, 1790) pode suavizar os costumes, enobrecer os sentimentos, promover a felicidade e beatitude, pois ela atua sobre a parte mais excitável [reizbar] do homem: sua sensibilidade [Sinnlichkeit]. A música em horas impróprias produz efeitos contrários; a música que não tem a menor relação com nós mesmos, seja pelo seu motivo [Veranlassung] ou pelo seu conteúdo, pode facilmente causar tédio; portanto, se se pretende que ela atue visando a finalidades melhores, ela deve ser usada com cautela.
} 
Que a música seja, dentre as belas-artes, aquela que proporciona menos cultura [Kultur], é algo que os admiradores do filósofo de Königsberg não admitem sem mais, e homens perspicazes de nossa época mostraram a falta de fundamento daquele rebaixamento [Herabsetzung] da música. Já o meio [Medium] e o //769// material [Stoff] da música suscitam uma vantagem para seu valor estético. Ela nos fala mediante o sentido da audição; seu meio - o ar - é invisível, assim como os sons. Como a música tem sua esfera no invisível [Unsichtbaren], como ela não oferece nada extenso ou nada persiste no espaço, ela atua de uma maneira espiritual [geistige Art]. Através da audição, recebemos o discurso [Rede], a expressão dos conceitos e das idéias, a comunicação da razão [Vernunft]. Esse nobre sentido para o invisível nos liga a um mundo espiritual [geistigen Welt]; da mesma forma se passa com a música. Ela nos cultiva, portanto, ao nos retirar do mundo corpóreo, e nos entreter com formas invisíveis. [...] Portanto, a música nos mergulha, tal como a poesia, no âmbito espiritual das sensações internas [innere Empfindungen], e nos oferece, no jogo dos sons, uma forma tão pura da beleza, como por exemplo, a escultura nos brancos bustos de gesso ou o desenho sem cor. [...] As sensações com as quais ela lida não são sua [finalidade] última; seu fim não é uma mera excitação dos nervos, assim como não é a cor das pinturas ou o brilho do mármore das colunas que constituem o efeito último dessas artes; é a imaginação [Einbildungskraft] que compõe [zusammensetzt] um todo [Ganzes] belo e sublime //770// e diversamente interessante, a partir das sensações auditivas; e na fruição obtida a partir daí, [é a imaginação] que nos eleva silenciosamente acima das necessidades corpóreas e dos estímulos sensoriais. Nós nos perdemos na contemplação espiritual [gesitigen Anschauen] do elemento objetivo de uma bela composição musical, tanto quanto na sublimidade de uma ode de Klopstock; mas com a diferença, que aqui [na ode] a nossa 
atividade é mais determinada, através de conceitos, enquanto lá [na música], a liberdade permanece, para acrescentar um conteúdo [Inhalt] para a mera forma da sensação.[...]

//771// [...] Gostaria de comunicar ainda as seguintes idéias acerca do valor característico da música, consciente da dificuldade de fazê-las completamente claras para mim, e distintas para os outros. Primeiramente, eu considero a música segundo sua perfeição interna, na consumação estética de suas formas, de suas representações. Em suas obras configuradas idealmente, ela merece, a meu ver, uma dignidade estética pura, assim como as outras artes. Ela é uma das belas-artes, tanto quanto a poesia e as artes plásticas. Seu material [Stoff] e seus meios [Mittel] não prejudicam sua dignidade: pelo contrário, eles a favorecem. [...] Ela consegue, assim como as outras artes belas, representar o belo e o sublime. Que ela o faça pelo caminho da audição e, ao mesmo tempo, mova nossos nervos; em suma, que ela fale aos nossos sentidos, que ela tenha que afetar nosso corpo, para colocar nossa imaginação em jogo, tudo isso a desvaloriza tão pouco como qualquer outra das belas-artes é desvalorizada, por precisar atuar primeiramente sobre os nossos sentidos, e por não poder excluir os estímulos a nossa faculdade dos sentidos. A música deve ser considerada, talvez, como a mais livre dentre as demais artes, porque ela se apodera de nossa imaginação da maneira mais imediata, e pode preenchê-la com formas belas e sublimes, sem estar limitada ao âmbito dos conceitos do entendimento ou das intuições da efetividade comum. Nela, o individual e o ideal parecem unir-se da maneira mais fácil e íntima, nela se expressa talvez da maneira mais viva (como dizem os estetas modernos) a infinito através do finito [das Unendliche durch das Endliche] $[\ldots]$. 
Apêndice 4: MICHAELIS, C. F. "Ueber das Idealische der Tonkunst". In: AmZ 10, Nr. 29 (13.04.1808).

\section{Sobre o [elemento] ideal da música}

//449//

Dentre todas as belas-artes não há nenhuma que apareça aos homens de maneira mais ideal [idealischer] e original [origineller] em suas obras, do que a música. Em nenhuma fica mais evidente do que na música a inadmissibilidade da afirmação de que a arte bela consistiria na mera imitação [Nachahmung] da natureza. Que arte insignificante ela seria, se ela nada mais fosse que uma repetição [Wiederholung] dos sons que se pode ouvir sem quaisquer regras da arte no mundo vivo ou inanimado! A música cria [schafft] um todo tão infinitamente variado de sons, em suas composições melódicas e harmônicas produz por magia um mundo inteiramente próprio para nossa fantasia, que seria em vão que nós procuraríamos um original [ein Original] para isto na realidade desprovida de arte. As outras artes podem ser ainda geniais em suas invenções, contudo, na verdade de sua exposição de efetivas relações vivas, ao recordar cenas semelhantes à natureza, não raro elas tiram daí um grande interesse, e ganham com isso a nossa simpatia. A música, pelo contrário, encanta através de fenômenos completamente novos, apresenta-se, ela mesma, como criadora de cenas que são configuradas apenas a partir do mundo interior da humanidade, mas que não possuem um modelo [Urbild] na natureza exterior, nem segundo a forma [Form], nem segundo o material [Stoff]. Em sua liberdade e particularidade, ela expõe, portanto, de maneira inteiramente pura, o espírito da arte [Geist 
der Kunst]. A imaginação poética, criadora [dichtende, schaffende Einbildungskraft], //450// revela todo o seu poder na música. O valor de obras musicais consumadas [Vollendete] não está meramente em representar [vorstellen] ou significar algo outro, mas naquilo que elas mesmas são, em sua própria e incomparável essência. Mesmo quando a música dá expressão a certas paixões, afetos, estados de ânimo e, por assim dizer, os descreve, ela o faz de tal forma, que fora de sua esfera, na natureza efetiva e individual, só são encontrados traços fracos e imperfeitos, e com uma particularidade e detalhe que excede toda a efetividade conhecida do mundo desprovido de arte. Suas melodias e harmonias não são emprestadas da natureza bruta ou das criaturas cantantes, como se quis presumir a fim de explicar a origem da música; mas sim, elas são invenção originária [ursprüngliche Erfindung] do homem pleno de sentimentos, dotado de imaginação e senso de proporção e eufonia [Wohlklang]: são produtos ideais [idealische Produkte] de uma faculdade poética [Dichtungsvermögen] ligada a uma organização afortunada. O pintor e o escultor podem, ambos, apontar para objetos naturais, que são semelhantes a suas obras ou dos quais, no todo ou em particular, muita coisa é abstraída, por mais original que seja a transformação ou o agrupamento, por mais novo e característico que possa ser também o emprego e manejo de um material [Stoff] abstraído do mundo exterior: somente o compositor [Tonkünstler] não encontra diante de si, na mera natureza, nenhum todo musical [musikalisches Ganze], //451// que ele, na imitação, tivesse apenas que elaborar e configurar; ele cria a verdadeira música meramente a partir de seu interior [aus seinem Innern], ainda que as experiências exteriores e os experimentos variados acerca do efeito do canto e da música instrumental possam sempre desenvolver e aperfeiçoar mais a música. O poeta encontra o seu meio de exposição - a linguagem das palavras - já 
inteiramente disponível, e pode modificá-la somente conforme o seu fim [Zweck]; também na poesia, ele se refere sempre a objetos do conhecimento [Gegenstände der Erkenntnis] ou a idéias da razão [Ideen der Vernunft]; sua comunicação encontra sempre exemplos no mundo real ou possível; ela personifica e individualiza também o universal e abstrato, a fim de dar clareza e vida interior à sua expressão. $O$ compositor, pelo contrário, configura [bildet] para si sua própria linguagem; as melodias e modulações da música são algo originário [Ursprünglich], gerados a partir da força interior. A música não recebe sua lei de nenhuma linguagem existente, mas pelo contrário, é sua própria legisladora [Gesetzgeberin], ao fluir, ela mesma, do mais íntimo da humanidade e só se submeter às leis eternas da Harmonia, que estão fundadas na essência dos indivíduos dotados de razão e de organização sensível. Portanto, a música encontra-se, enquanto predisposição [Anlage], no mais profundo da natureza humana, e se desenvolve e amadurece cada vez mais através de variados produtos em direção à perfeição [Vollkommenheit]. Mas ela não pode verificar nos produtos da natureza o grau de perfeição alcançado por suas obras, tal como o escultor ou o pintor, em suas obras, consultam a proporção em corpos humanos configurados com regularidade. A música tem que alcançar seu aperfeiçoamento apenas através do exercício freqüente e do refinamento do ouvido musical e do gosto; ela possui muita liberdade no que concerne à Melodia, mas com relação à Harmonia ela está sob relações que podem ser calculadas matematicamente. Ela não //452// se refere a objetos determinados do conhecimento, também não designa imediatamente nenhuma idéia da razão, mas ela pode expressar os próprios sentimentos [Gefühle] que certos objetos e idéias despertam em nós. Ela pode indicar simbolicamente [sinnbildlich] e descrever o que nosso espírito intui [anschaut] ou pensa. Dentre outros autores, Reichardt manifestou-se com 
poucas palavras, mas de maneira significativa, acerca da força característica e da sublimidade da música, mesmo em comparação com a poesia. "Onde as palavras não mais conseguem, não mais são suficientes, os sons, as harmonias expressam o inefável [das Unaussprechlich] e elevam o entusiasta [Begeisterten] muito acima de si mesmo. A construção dos versos e o ritmo poético mais perfeito recebem, eles mesmos, a sua mais elevada força e efeito somente mediante o ritmo musical que a ele se agrega; unidas, elas entusiasmam e fascinam, alçando a alma à elevação [Aufschwung] suprema, divina, e baixando-a, de novo, no abismo do aniquilamento [Abgrund der Vernichtung]". 
Apêndice 5: HOFFMANN, E. T. A. Schriften zur Musik. Darmstadt: WBG, 1971.

//34//

Sinfonie pour 2 Violons, 2 Violes, Violoncelle et Contre-Violon, 2 Flûtes, petite Flûte, 2 Hautbois, 2 Clarinettes, 2 Bassons, Contrebasson, 2 Cors, 2Trompettes, Timbales et 3 Trompes, composée et dediée, etc. par Louis van Beethoven, à Leipsic, chez Breitkopf et Härtel, Oeuvre 67, No. 5 des Sinfonies. (Pr. 4 Rthlr. 12 Gr.) $)^{529}$

O Recensor tem diante de si uma das mais importantes obras do Mestre, ao qual atualmente ninguém contestará o primeiro lugar dentre os compositores de música instrumental; ele está impregnado pelo objeto sobre o qual ele deve falar e ninguém poderá levá-lo a mal se, ultrapassando os limites usuais das recensões, ele aspire a exprimir com palavras aquilo que sentiu no fundo da alma com esta composição. -

Quando se fala da música enquanto uma arte autônoma [selbständigen Kunst], dever-se-ia pensar somente na música instrumental, a qual, desprezando toda ajuda e toda mistura de uma outra arte, exprime de maneira pura a essência da arte [Wesen der Kunst], que somente nela se faz reconhecer. Ela é a mais romântica das artes [romantischste aller Künste] - poder-se-ia quase dizer: a única puramente romântica. A lira de Orfeu abriu as portas do Hades. A música abre ao homem um reino desconhecido [unbekanntes Reich]; um mundo que nada tem em comum com o mundo exterior dos sentidos [äußern Sinnenwelt] que o circunda, e no qual ele deixa para trás todos os sentimentos definíveis através de conceitos, para se entregar ao inefável [Unaussprechlichen]. Quão pouco os compositores de música

${ }^{529}$ Em francês no original [N.T.] 
instrumental reconheceram essa essência característica [eigentümliche Wesen] da música, ao tentar representar aqueles sentimentos determináveis [bestimmbaren Empfindungen], ou até mesmo acontecimentos, tratando de maneira plástica a arte que é a mais oposta às artes plásticas! As sinfonias desse gênero compostas por Dittersdorf, bem como todas essas recentes Batailles des trois Empereurs, etc. são equívocos ridículos, que devem ser punidos com o total esquecimento. No canto [Gesang], onde a poesia sugere afetos definidos [bestimmte Affekte] através das palavras, a força mágica da música atua como o elixir milagroso dos sábios, do qual algumas gotas transformam qualquer bebida em algo esplêndido e delicioso. A música reveste do esplendor purpúreo do Romantismo toda paixão - //35// amor - ódio - cólera desespero etc., tal como a ópera nos dá; e mesmo os [sentimentos] que nós experimentamos na vida, nos conduzem para fora da vida: ao reino do infinito [Reich des Unendlichen]. Tão poderosa é a magia [Zauber] da música, e, atuando de maneira cada vez mais potente, ela teria que romper todos os grilhões [que a prendem] às outras artes. -

Certamente não é apenas devido à maior facilidade dos meios de expressão (aperfeiçoamento dos instrumentos, maior virtuosidade dos intérpretes), mas também a um conhecimento mais profundo e mais íntimo da essência característica da música, que os compositores geniais elevaram a música instrumental ao ápice atual. Haydn e Mozart, os criadores [Schöpfer] da nova música instrumental, foram os primeiros a nos mostrar a arte em toda a sua glória; quem a contemplou com um amor pleno [voller Liebe] e penetrou na sua essência mais íntima foi Beethoven. As composições instrumentais desses três mestres respiram um mesmo espírito romântico [romantischen Geist], o qual está justamente na mesma compreensão íntima da essência característica da 
arte; o caráter [Charakter] de suas composições, contudo, diferencia-se consideravelmente.

Nas composições de Haydn domina a expressão de um ânimo ingênuo [kindlichen Gemüt] e alegre. Sua sinfonia nos conduz a bosques vastos e verdejantes, a uma alegre e colorida multidão de pessoas felizes. Passam meninos e meninas, pairando em danças [Reihentänzen]; crianças sorridentes, aguçando o ouvido atrás das árvores e dos arbustos de rosas, brincam de jogar flores umas nas outras. Uma vida plena de amor, plena de bem-aventurança, tal como antes do pecado original, numa juventude eterna; nenhum sofrimento, nenhuma dor; apenas um doce e melancólico desejo [wehmütiges Verlangen] pela figura amada, que paira ao longe, no esplendor do crepúsculo, sem se aproximar nem desaparecer; e enquanto ela está ali não anoitece, pois ela mesma é o crepúsculo incandescente das montanhas e dos bosques. -

Mozart nos conduz às profundezas do reino dos espíritos [Geisterreich]. O temor [Furcht] nos cerca: mas sem martírio [Marter], ele é antes, pressentimento do infinito [Ahnung des Unendlichen]. Amor e melancolia ressoam em vozes benévolas, a noite do mundo dos espíritos [Geisterwelt] se levanta num luminoso esplendor purpúreo, //36// e num anseio indizível [unaussprechlicher Sehnsucht], seguimos as figuras [Gestalten] que nos chamam cordialmente a suas fileiras, e pairam na dança eterna das esferas através das nuvens. (Por exemplo, a Sinfonia em Mi Bemol Maior, de Mozart, conhecida pelo nome de "Canto do cisne").

Assim também a música instrumental de Beethoven nos abre o reino do colossal [Ungeheueren] e do incomensurável [Unermeßlichen]. Raios incandescentes penetram através da profunda noite desse reino, e nós reconhecemos as sombras gigantescas que se agitam como ondas e nos circundam, cada vez mais perto, e aniquilam [vernichten] tudo em nós, 
exceto a dor do anseio infinito [Schmerz der unendlichen Sehnsucht], na qual todo prazer [Lust], que sobe rapidamente em sons jubilosos, diminui e submerge, e [como] visionários extasiados [entzückte Geisterseher], nós seguimos vivendo somente nessa dor que, consumindo em si - mas sem os destruir - o amor, a esperança e a alegria, quer fazer nosso peito explodir com o ressoar conjunto de todas as paixões.

O gosto romântico [romantische Geschmack] é raro; ainda mais raro é o talento romântico; é provavelmente por esse motivo que há tão poucos que conseguem fazer ressoar aquela lira que abre o reino maravilhoso do infinito [wundervolle Reich des Unendlichen]. Haydn tem uma concepção romântica do humano na vida humana; ele é mais comensurável [kommensurabler] para a maioria [das pessoas]. Mozart recorre ao sobre-humano [Übermenschliche], ao maravilhoso [Wunderbare], que habita no espírito interior. A música de Beethoven move a alavanca do terror [Schauer], do temor [Furcht], do horror [Entsetzen], da dor [Schmerz], e suscita aquele anseio infinito [unendliche Sehnsucht], que é a essência do Romantismo. Beethoven é um compositor puramente romântico (e, justamente por isso, um compositor verdadeiramente musical). Talvez seja por isso que ele não se sai tão bem na música vocal - a qual não admite [nenhum] anseio indeterminado [unbestimmtes Sehnen], mas pelo contrário, representa apenas os afetos designados através de palavras, como sentidos no reino do infinito - e sua música instrumental raramente agrada à multidão. Essa mesma multidão, que não penetra na profundidade [Tiefe] de Beethoven, não Ihe nega um elevado grau de fantasia [Phantasie]; por outro lado, ele vê freqüentemente em suas obras apenas produtos de um gênio que, sem se preocupar com a forma [Form] e a escolha [Auswahl] das idéias [Gedanke], se abandona ao seu fogo [Feuer] e //37// às inspirações [Eingebungen] súbitas de sua imaginação [Einbildungskraft]. Não 
obstante, no que se refere à reflexão [Besonnenheit], ele deve ser colocado ao lado de Haydn e Mozart. Ele separa o seu eu [lch] do reino interior dos sons e comanda a este como senhor absoluto. Assim como os estéticos artistas-medidores [Meßkünstler] freqüentemente deploraram a total falta de uma verdadeira unidade [Einheit] e de coerência interna [inneren Zusammenhang] em Shakespeare; e somente 0 olhar aprofundado [apreende] que uma bela árvore, [com seus] botões e folhas, flores e frutos, resulta de uma única semente: da mesma forma, é somente um detalhamento [Eingehen] muito profundo na estrutura interna na música de Beethoven que revela a elevada reflexão [hohe Besonnenheit] do Mestre, reflexão esta que é inseparável do verdadeiro gênio e que é nutrida pelo contínuo estudo da arte [anhaltenden Studium der Kunst]. É no fundo de seu ânimo [Gemüt] que Beethoven porta o Romantismo da música, que ele exprime com elevada genialidade e reflexão em suas obras. O Recensor jamais o sentiu de maneira mais vivaz do que na presente sinfonia, a qual, num clímax que vai se intensificando até o final, revela aquele Romantismo de Beethoven mais do que qualquer outra de suas obras e que impele irresistivelmente 0 ouvinte para o maravilhoso reino espiritual do infinito [wundervolle Geisterreich des Unendlichen].

O primeiro Allegro, em compasso de $2 / 4$, dó menor, inicia-se com uma idéia principal [Hauptgedanke] de apenas dois compassos, a qual reaparecerá em seguida sob múltiplas formas. No segundo compasso [cp. $77^{530}$, uma fermata; depois uma repetição daquela idéia um tom abaixo, e novamente uma fermata; em ambas as vezes somente os instrumentos de cordas e os clarinetes [se fazem ouvir]. Nem mesmo a tonalidade [Tonart] está ainda definida; o ouvinte supõe [o tom de] Mi Bemol Maior.

530 Os números de compasso entre colchetes não constam do original. Foram acrescentados pelo tradutor a fim de facilitar o cotejamento da análise com a partitura [N.T.] 
Os segundos violinos iniciam novamente a idéia principal; no segundo compasso, a fundamental [Grundton] dó tocada pelos violoncelos e fagotes define a tonalidade de dó menor, enquanto que as violas e os primeiros violinos entram em imitações, até que por fim estes últimos acrescentem dois compassos à idéia principal, os quais, repetidos por três vezes (sendo a última com a entrada [cp. 18] da orquestra inteira) e terminando numa fermata [cp. 21] sobre a dominante, fazem com que o ânimo [Gemüt] do ouvinte pressinta o desconhecido [Unbekannte], o misterioso [Geheimnisvoll]. $O$ início do Allegro até essa pausa decide 0 caráter [Charakter] da peça inteira //38// e justamente por isso o Recensor o insere aqui para exame do leitor:

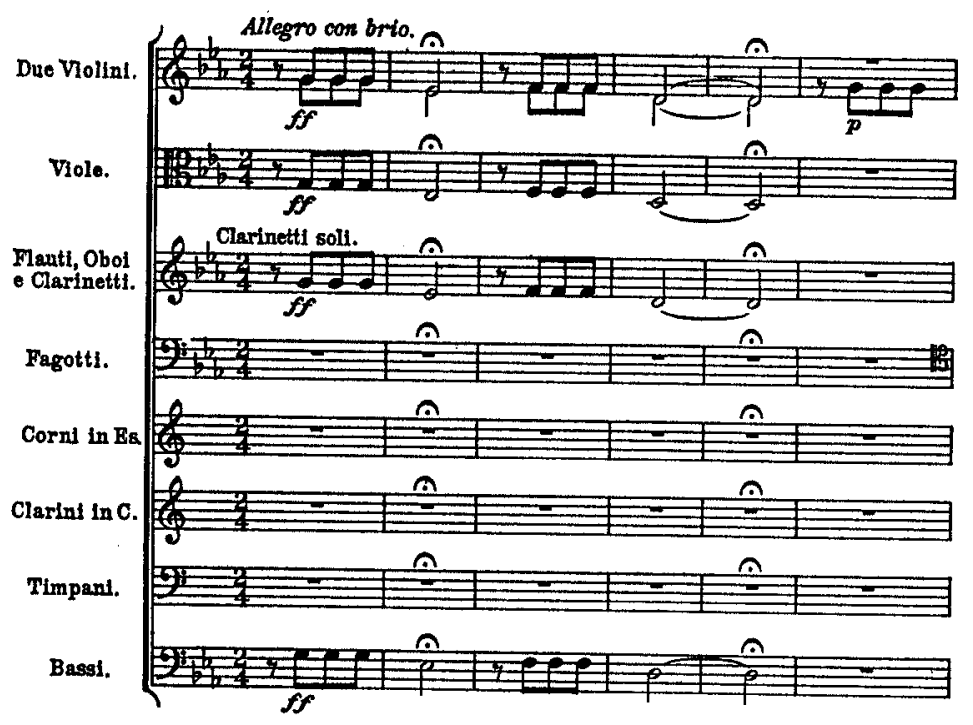




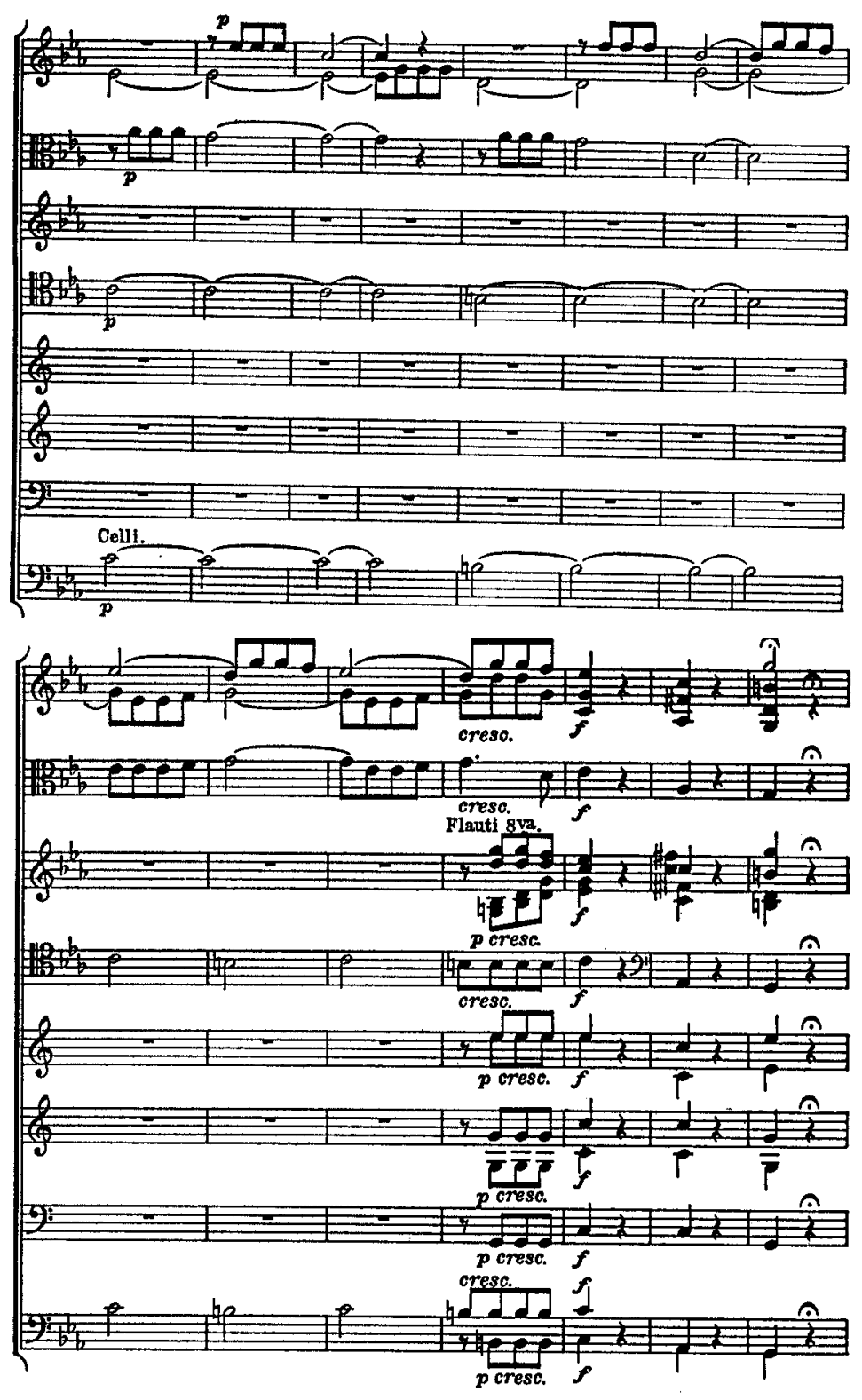

//39// Após essa fermata, os violinos e violas imitam a idéia principal, permanecendo na tônica, enquanto os baixos tocam, de quando em quando, uma figura [Figur] que imita aquela idéia [Gedanke], até que um episódio [Zwischensatz] sempre crescente, que suscita novamente aquele pressentimento [Ahnung] de maneira mais forte e urgente, conduz a um 
Tutti [cp. 44] cujo tema apresenta o mesmo ritmo que a idéia principal e que lhe é intimamente aparentada:

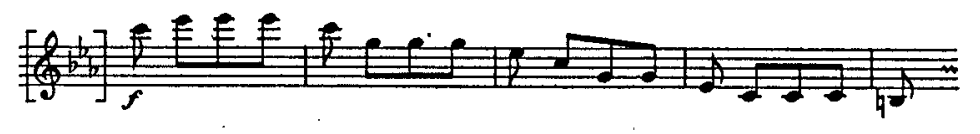

O acorde de sexta [Sexten-Akkord] sobre a nota fundamental [Grundton] ré [cp. 58], prepara [a modulação para] a tonalidade relativa de Mi Bemol Maior, na qual a trompa [cp. 59] imita novamente as idéias principais.

Os primeiros violinos [cp. 63] expõem agora um segundo tema [zweites Thema], o qual embora melodioso, permanece fiel ao caráter [Charakter] de anseio [Sehnsucht] apreensivo e inquieto que se exprime no movimento [Satz] inteiro. Os violinos apresentam esse tema em alternância com os clarinetes [cp. 67], //40// enquanto que a cada três compassos [cp. 65] os baixos retomam aquela imitação anteriormente mencionada da idéia principal [Hauptgedanke], através da qual esse tema é tecido com arte na trama do todo [Ganzen]. Na continuação desse tema, o primeiro violino e o violoncelo repetem cinco vezes uma figura de dois compassos no tom de mi bemol menor [cp. 83], enquanto os baixos vão subindo cromaticamente, até que finalmente um novo episódio [ $c p$. 95] conduz à cadência, na qual os instrumentos de sopro repetem o primeiro Tutti em Mi Bemol Maior, e por fim, a orquestra inteira conclui com essa imitação mencionada diversas vezes, do tema principal no baixo em Mi Bemol Maior.

A segunda parte ${ }^{531}$ começa novamente com o tema principal [Hauptthema] sob a primeira forma, mas agora [transposto] uma terça acima e executado pelos clarinetes e pelas trompas [cp. 125]. As frases

$\overline{531}$ Isto é, o desenvolvimento [N.T.]. 
[Sätze] da primeira parte seguem-se em fá menor [cp. 130], dó menor [cp. 146] e sol menor [cp. 154], mas agora apresentadas e instrumentadas de maneira diferente, até que finalmente, após um episódio [cp. 158] - que, novamente, consiste em apenas dois compassos retomados em alternância pelos violinos e pelos instrumentos de sopro, enquanto os violoncelos executam uma figura em movimento contrário, e os baixos em movimento ascendente - a orquestra inteira executa os seguintes acordes [cp. 168]:

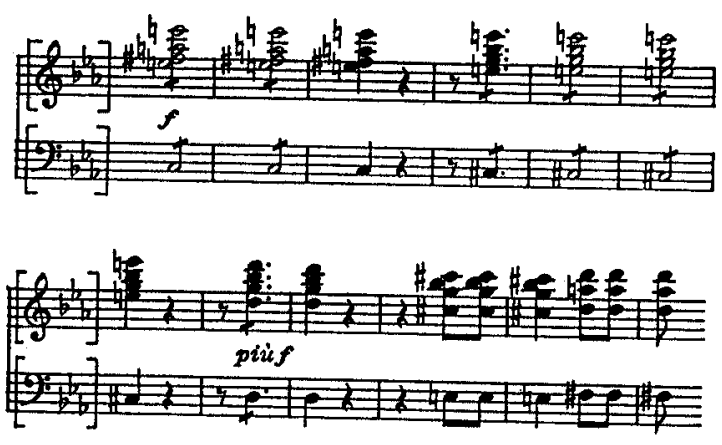

São sons [Laute] com os quais o peito, oprimido e atemorizado com pressentimentos da imensidão [Ahnungen des Ungeheuren], se alivia violentamente; e, tal como uma figura amável que, brilhando e iluminando a noite profunda, penetra através das nuvens, entra agora um tema que havia sido apenas esboçado pelas trompas, no compasso 59 da primeira parte, em mi bemol maior. Esse tema é executado agora //41// pelos violinos alla 8va [cp. 179], primeiramente em Sol Maior, e depois em Dó Maior, enquanto os baixos executam uma figura descendente que, de certo modo, recorda a frase em Tutti do compasso 44 da primeira parte. 


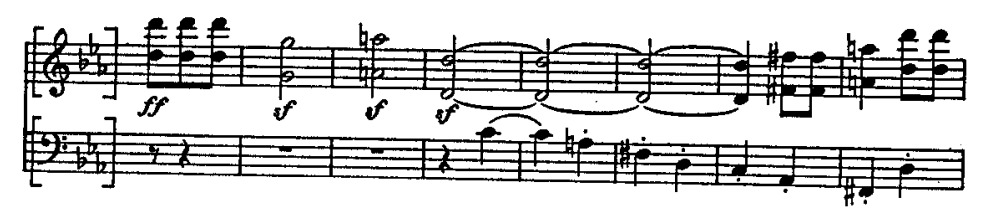

Os instrumentos de sopro iniciam esse tema em fá menor fortíssimo [cp. 195], mas, após três compassos, os instrumentos de cordas se encarregam dos dois últimos compassos [cp. 198] e, imitando esses compassos, os instrumentos de corda e os de sopro alternam-se ainda por cinco vezes, e então, novamente de maneira alternada [cp. 210] e sempre diminuendo, executam acordes isolados. Após o acorde de sexta [cp. 214]: o Rec.[ensor] teria esperado sol bemol menor no encadeamento de acordes posterior, que então poderia ser transformado enarmonicamente em fá sustenido menor, para que modulasse para Sol Maior, como ocorre aqui. Mas os acordes executados pelos instrumentos de sopro, e que se seguem àquele acorde de sexta [anteriormente

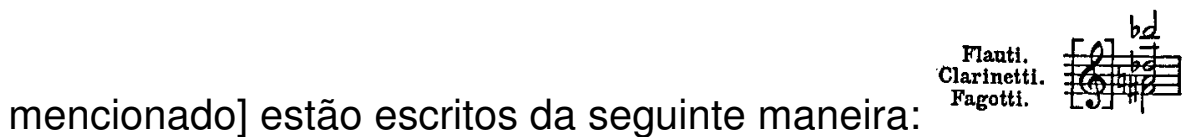

Logo em seguida os instrumentos de corda atacam o acorde de fá sustenido menor [cp. 216], que é então repetido quatro vezes, alternando com os instrumentos de sopro e sempre com a duração de um compasso. Os acordes dos instrumentos de sopro prosseguem escritos da maneira indicada acima, para a qual o Rec.[ensor] não encontra nenhuma justificativa. Segue-se então, do mesmo modo, o acorde de sexta: sempre mais e mais fraco [schwach]. Isso provoca novamente um efeito cheio de pressentimentos [ahnungsvoll] e horripilante [schauerlich]! - A orquestra irrompe [cp. 228] então com um 
tema quase totalmente idêntico àquele iniciado 41 compassos antes [ $c p$. 187], //42// unisono, em Sol Maior, e apenas as flautas e trompetes sustentam a dominante Ré. Mas já no quarto compasso esse tema se interrompe. Os instrumentos de cordas, alternando com as trompas e depois com os demais instrumentos de sopro, tocam por sete vezes e em pianissimo o acorde de sétima diminuta [cp. 233]: baixos retomam [cp. 240] a primeira idéia principal [Hauptgedanken] sobre um uníssono dos outros instrumentos e, no segundo compasso, os instrumentos restantes em unisono; durante cinco compassos o baixo e a voz superior [Oberstimme] se imitam dessa maneira, unindo-se em seguida por três compassos, e no quarto compasso a orquestra inteira [cp. 248], com tímpanos e trompetes, ataca o tema principal em sua configuração originária. A primeira parte é então repetida ${ }^{532} \mathrm{com}$ mínimas diferenças; o [segundo] tema, que antes ${ }^{533}$ começava em Mi Bemol Maior, entra agora em Dó Maior e conduz jubilosamente à cadência em Dó Maior [cp. 370] com tímpanos e trompetes. Entretanto, com essa mesma cadência a frase se volta para fá menor. Ao longo de cinco compassos a orquestra inteira executa 0 acorde de sexta [cp. 382] . Os clarinetes, os oboés e as trompas [cp. 387] seguem piano com uma imitação do tema principal. Um compasso de silêncio [cp. 389]; depois, durante mais seis compassos [cp. 390] Todos os instrumentos de sopros seguem-se novamente como antes: e agora as violas, violoncelos e fagote executam um tema que já aparecera anteriormente em Sol Maior, na segunda parte ${ }^{534}$, enquanto que os violinos, entrando em

\footnotetext{
${ }^{532}$ Isto é, tem início a reexposição [N.T.]

${ }^{533}$ Isto é, na exposição [N.T.]

${ }^{534}$ Isto é, no desenvolvimento [N.T.]
} 
unisono no terceiro compasso [cp. 400], executam um novo contra-sujeito [Gegensatz]. Agora a frase permanece em dó menor, e o tema (que havia começado no compasso 71 da primeira parte) é repetido, com algumas pequenas variações, a princípio somente pelos violinos e depois alternando com os instrumentos de sopros. Aproximando-se cada vez mais e mais perto (primeiro um compasso, depois meio compasso); é tamanho ímpeto e movimento - é um rio transbordante, e cujas ondas se golpeiam cada vez mais e mais alto - até que, finalmente, 24 compassos antes do final [cp. 478], o início do Allegro é repetido mais uma vez. Segue-se um pedal [Orgelpunkt], sobre o qual o tema é imitado, até que, por fim, segue-se a conclusão, forte e robusta. -

//43// Não há idéia [Gedanke] mais simples do que aquela que o Mestre utilizou como fundamento do Allegro inteiro:

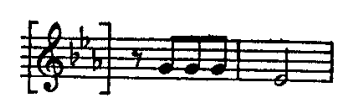

e com admiração nos damos conta de como ele, através dos procedimentos rítmicos, soube acrescentar todas as idéias secundárias [Nebengedanken] e todos os episódios [Zwischensätze] a esse tema simples, de modo a que eles servissem apenas para desdobrar [entfalten] sempre mais e mais o caráter do todo [Charakter des Ganzen], que aquele tema podia apenas indicar. Todas as frases são curtas, consistindo em apenas dois, três compassos e são, além disso, distribuídas numa alternância constante dos instrumentos de corda e dos instrumentos de sopro. Dever-se-ia crer que, a partir de tais elementos somente poderia surgir algo fragmentado [Zerstückeltes], difícil de compreender [schwer zu Fassendes]: mas ao invés disso, é justamente esse arranjo do todo [Einrichtung des Ganzen], assim como a constante e 
sucessiva repetição das frases curtas e de acordes isolados, que prendem [festhalten] o ânimo [Gemüt] num anseio inefável [unnennbaren Sehnsucht]. - À parte o fato de que o tratamento contrapontístico é testemunha de um profundo estudo da arte [tiefem Studium der Kunst], são também os episódios e as constantes alusões ao tema principal que nos deixam reconhecer como o Mestre não apenas concebeu o todo [das Ganze] em seu espírito, com todos os traços plenos de caráter, mas ainda, que [o todo] foi profundamente refletido [durchdachte]. -

Como uma graciosa voz dos espíritos [Geisterstimme], que preenche nosso peito com consolo e esperança, ressoa depois disso o tema suave (e, no entanto, pleno de conteúdo) do Andante em Lá Bemol Maior, em compasso 3/8, executado pela viola e pelo violoncelo. A execução [Ausführung] ulterior do Andante recorda alguns movimentos intermediários nas Sinfonias de Haydn; tal como acontece ali com muita freqüência, também aqui o tema é variado de múltiplas formas após a entrada de cada episódio [Zwischensatz]. Quanto à originalidade, não se pode comparar [este movimento] ao Allegro - muito embora a pomposa frase em Dó Maior [cp. 32], com tímpano e trompetes, que aparece entre as passagens em Lá Bemol Maior, produzam um efeito supreendente [frappant]. A transição [Übergang] para Dó Maior ocorre duas vezes [cp. 28 e 77], por meio de enarmonia [cp. 28]://44//

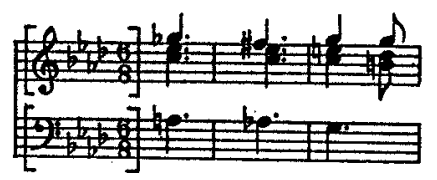

depois [dessa transição] entra aquele tema pomposo e, então, a modulação [Modulation] de volta para o acorde de dominante de Lá Bemol Maior acontece da seguinte maneira [cp. 41 e 90]: 


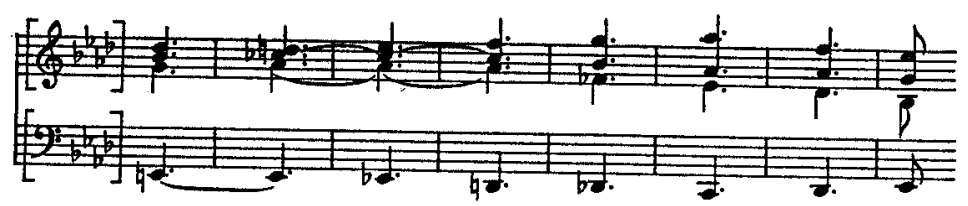

A maneira pela qual as flautas, os oboés e os clarinetes preparam a terceira transição [cp. 144] para aquele tema em Dó Maior é mais simples, mas causa bastante efeito [Wirkung]:

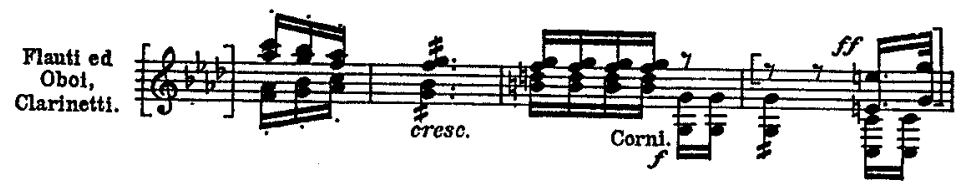

Todas as frases do Andante são muito melodiosas [melodiös], e a frase principal é até delicada [schmeichelnd]; mas [até] mesmo o percurso desse tema (que passa por Lá Bemol Maior, si bemol menor, fá menor, si bemol menor, e só então retorna para Lá Bemol), a justaposição das tonalidades maiores de Lá Bemol e Dó, as modulações cromáticas exprimem novamente o caráter do todo [Charakter des Ganzen], do qual, justamente por isto, o Andante é uma parte. - É como se o espírito terrível [furchtbare Geist], que tomou e angustiou o ânimo [Gemüt] no Allegro, ameaçador a cada instante, emergisse das nuvens tempestuosas nas quais ele havia desparecido, e então, diante de seu olhar, as amáveis figuras que nos rodeavam de maneira consoladora fugissem rapidamente.

O Menuett que se segue ao Andante é novamente tão original [originell] e comove tanto o ânimo do ouvinte, como se poderia esperar do Mestre na composição desta parte da Sinfonia - que, segundo a forma Haydniana, que ele seguiu, deve ser a mais picante //45// e espirituosa [geistreicheste] do todo.

São principalmente as modulações peculiares, as cadências no acorde maior da dominante, cuja fundamental [Grundton] o baixo retoma como tônica do tema seguinte em modo menor [cp. 44] - esse próprio tema que se expande sempre em apenas alguns compassos - que 
expressam vivamente o caráter da música de Beethoven, como o Rec[ensor] indicou acima, e que excitam novamente aqueles pressentimentos do maravilhoso reino dos espíritos [Ahnungen des wunderbaren Geisterreichs], com os quais as frases do Allegro acossavam o ânimo do ouvinte. O tema em dó menor, executado apenas pelos baixos, dirige-se para sol menor no terceiro compasso, as trompas sustentam o sol e os violinos e violas, com os fagotes no segundo compasso [cp. 6] e depois com os clarinetes [cp. 7], executam uma frase de quatro compassos que cadencia em sol [cp. 8]. Os baixos repetem então o tema, mas depois do terceiro compasso, o sol menor se dirige para ré menor [cp. 13], depois para dó menor [cp. 16], e aquela frase dos violinos [cp. 15] é repetida. As trompas [cp. 19] expõem agora uma frase que vai para Mi Bemol Maior, enquanto os instrumentos de cordas tocam acordes em semínimas no começo de cada compasso. A orquestra, contudo, expõe o tema mais adiante em mi bemol menor [cp. 28] e cadencia na dominante $\mathrm{Si}$ Bemol Maior [cp. 44]: mas no mesmo compasso o baixo começa o tema principal, e ele o expõe exatamente como no começo em dó menor, só que agora em si bemol menor. Também os violinos etc., repetem a sua frase [cp. 49] e segue-se uma fermata em Fá Maior. O baixo repete aquele tema, mas o amplia [erweitert], ao percorrer fá menor [cp. 56], dó menor [cp. 58], sol menor [cp. 60] e, então, retornar para dó menor [cp. 72], depois do que, o Tutti, que ocorreu primeiramente em mi bemol menor [cp. 28], conduz a frase, através de fá menor [cp. 80], para o acorde de Dó Maior [cp. 96]; porém, assim como ocorreu antes na passagem de Si Bemol Maior [cp. 44] para si bemol menor, o baixo retoma a fundamental Dó como tônica do tema em dó menor [cp. 97]. As flautas e os oboés [cp. 101], com a imitação dos clarinetes no segundo compasso [cp. 102], executam agora a frase que tinha sido executada anteriormente pelos instrumentos de cordas, 
enquanto estes repetem um compasso [cp. 101] que havia sido tocado anteriormente pelo Tutti [cp. 79]; as trompas sustentam o sol, os violoncelos começam um novo tema [cp. 101], ao qual se une a frase inicial dos violinos numa outra elaboração [Ausführung], e depois uma nova frase [cp. 116] em colcheias (que ainda não tinham aparecido). Mesmo o novo //46// tema dos violoncelos contém alusões ao tema principal e, com isso, assim como através do mesmo ritmo, intimamente aparentado a este [ao tema principal]. Após uma curta repetição, aquele Tutti conclui essa parte do minueto com tímpanos e trompetes em dó menor fortíssimo [cp. 133]. Os baixos começam a segunda parte (o Trio) com um tema em Dó Maior [cp. 141], que as violas imitam na dominante de maneira fugada [cp. 147], seguidas de maneira abreviada pelos segundos violinos [ $c p$. 153], e igualmente pelos primeiros violinos [ $c p$. 155] em stretto [Restriktion]. A primeira metade dessa parte ${ }^{535}$ cadencia em Sol Maior [cp. 160]. Na segunda parte [do Trio], os baixos iniciam o tema por duas vezes [cp. 162] e param, prosseguindo na terceira vez [cp. 166]. Para muitos, isso pode parecer burlesco [scherzhaft]; no Rec[ensor], isso despertou um sentimento inquietante [unheimliches Gefühl]. - Após diversas imitações do tema principal, este é retomado pelas flautas [ $c p$. 182], sustentadas pelos oboés, clarinetes e fagotes, enquanto as trompas sustentam a fundamental sol; depois, o tema vai morrendo em notas isoladas, tocadas primeiramente pelos clarinetes [cp. 229] e fagote, e depois pelos baixos [cp. 231]. Segue-se então a repetição do tema da primeira parte [cp. 236] pelos baixos; ao invés dos violinos, agora são os instrumentos de sopro [cp. 241] que executam a frase com notas curtas, que terminam com uma fermata [cp. 244]. Depois disso, assim como na primeira parte, [ouve-se] a frase principal expandida [cp. 245], mas ao invés de mínimas, temos agora semínimas e pausas de semínimas; é

${ }^{535}$ Isto é, do Trio [N.T.] 
com essa configuração que retornam também as outras frases da primeira parte, na maior parte das vezes abreviadas [abgekürzt]. - O anseio inquieto [unruhvolle Sehnsucht], que o tema leva em si, é agora intensificado até o medo [Angst], que aperta o peito violentamente; dele fogem apenas alguns sons interrompidos e isolados. O acorde de Sol Maior [cp. 323] parece conduzir para o final; mas o baixo sustenta agora a nota fundamental Lá Bemol [cp. 324], em pianíssimo, ao longo de quinze compassos, igualmente, violinos e violas sustentam a terça Dó, enquanto o tímpano toca o Dó [cp. 325] primeiramente no ritmo daquele Tutti freqüentemente mencionado, e depois uma vez por compasso [cp. 328], ao longo de quatro compassos, em seguida duas vezes por compasso [cp. 332] durante quatro compassos, e depois em semínimas [cp. 336]. Finalmente o primeiro violino retoma o primeiro tema [cp. 339] e conduz a frase até a sétima de dominante do tom fundamental, durante 28 compassos e sempre aludindo àquele tema; durante todo esse tempo, o segundo violino e a viola sustentaram o Dó, o tímpano tocou o Dó //47// em semínimas; o baixo, após fazer uma escala de Lá Bemol [cp. 341] até Fá Sustenido [cp. 344] e voltar para Lá Bemol [cp. 348], toca a fundamental Sol [cp. 350] em semínimas. Então atacam primeiramente os fagotes [cp. 366], um compasso depois, os oboés [cp. 367], e três compassos depois as flautas [cp. 370], trompas e trompetes, enquanto 0 tímpano prossegue tocando o Dó em colcheias, depois do que é feita a transição imediata da frase para o acorde de Dó Maior, com o qual se inicia o último Allegro. - Por que o Mestre deixou até o final a nota Dó dissonante ao acorde, no tímpano, explica-se a partir do caráter [Charakter] que ele pretendeu dar ao todo [Ganzen]. Esses golpes abafados e dissonantes, que agem [wirkend] como uma voz estranha e terrível [furchtbar], suscitam o terror do extraordinário [Schauer des Außerordentlichen] - do temor dos espíritos [Geisterfurcht]. O Rec[ensor] 
já mencionou acima o efeito [Wirkung] que vai se intensificando com o tema que se amplia em alguns compassos. Para tornar mais claro esse efeito, ele apresenta aqui, todas juntas, essas ampliações:

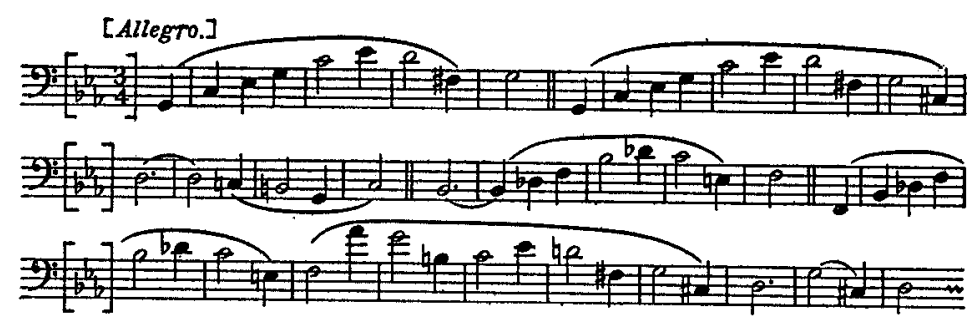

$\mathrm{Na}$ repetição da primeira parte [cp. 245], essa frase aparece da seguinte maneira:

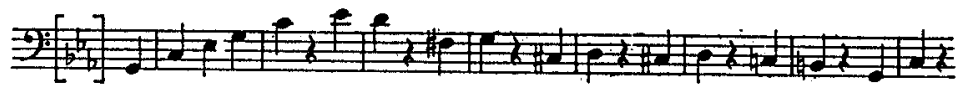

Igualmente simples e, contudo, - quando observado novamente através das frases posteriores - de um efeito tão arrebatador [eingreifender Wirkung] como o tema do primeiro Allegro, é a idéia do Tutti inicial do Minueto [cp. 27]:

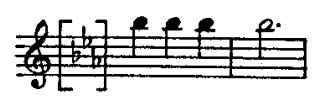

Com o tema suntuoso e exultante em Dó Maior do último movimento, ataca a orquestra inteira, à qual agora são acrescentadas ainda os flautins, trombones e contra-fagotes - como um //48// resplandecente e deslumbrante raio de sol que cega, que subitamente ilumina a noite escura. As frases desse Allegro são tratadas de maneira mais extensa que as [frases] precedentes: não tanto melodiosamente, do que fortes [kräftig] e aptas a imitações contrapontísticas: as modulações são compreensíveis e sem afetação [ungekünstelt]; especialmente a primeira parte possui quase o impulso da Abertura [Ouvertüre]. Durante trinta e quatro compassos essa parte em Dó Maior permanece como um Tutti da orquestra inteira; enquanto os baixos executam uma vigorosa 
figura [Figur] ascendente, um novo tema [cp. 34] na voz superior modula para Sol Maior e conduz para o acorde de dominante [cp. 41] dessa tonalidade. Então entra um novo tema [cp. 45], que consiste em semínimas alternadas com tercinas. Quanto ao seu ritmo e a seu caráter, ele diverge totalmente dos anteriores, e fornece um ímpeto e impulso, como as frases do primeiro Allegro e do Minueto:

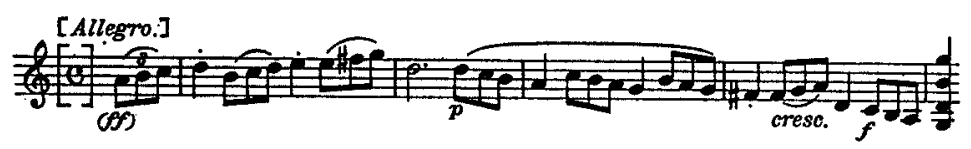

Através desse tema e de sua execução [Ausführung] posterior em Dó Maior [cp. 58], passando por lá menor [cp. 53], o ânimo [Gemüt] é transportado novamente para uma disposição de ânimo cheia de pressentimentos [ahnungsvolle], que se afasta dele por instantes com uma exaltação e júbilo. Com um Tutti curto e tempestuoso, a frase se dirige novamente para Sol Maior, e as violas, fagotes e clarinetes iniciam um tema em sextas [cp. 53], que é retomado em seguida pela orquestra inteira [cp. 72]. Após uma curta modulação para fá menor [cp. 77] (com uma vigorosa figura do baixo [cp. 80], que os violinos retomam em Dó Maior e, novamente, é executada pelos baixos al rovescio), a primeira parte termina em Dó Maior. A figura mencionada é mantida no começo da segunda parte ${ }^{536}$ em lá menor e aquele tema característico [cp. 90], consistindo em semínimas e tercinas, entra novamente. Com abreviações [Abkürzungen] e strettos, esse tema é desenvolvido durante trinta e dois compassos, e nesse desenvolvimento do caráter [Durchführung der Charakter], que já se exprimia em seu aspecto originário, [o tema] é desenvolvido [entwickelt] completamente, para o que contribuem em não menor medida os temas secundários [Nebensätze] acrescentados, os sons sustentados dos trombones, os tímpanos, trompetes e trompas que tocam em tercinas. //49// Finalmente a frase repousa no pedal em Sol,

\footnotetext{
${ }^{536}$ Isto é, do desenvolvimento [N.T.]
} 
executado primeiramente pelos baixos, mas enquanto estes executam uma figura cadencial [Schlussfigur] em unisono com os violinos, entram o trombone-baixo, trompetes, trompas e tímpanos. Então, durante cinquenta e quatro compassos, entra novamente aquele tema simples ${ }^{537}$ do Minueto:

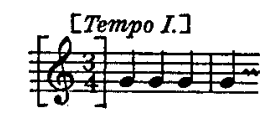

e nos dois últimos compassos ocorre a primeira transição do minueto para o Allegro, só que agora de maneira mais concisa. Com pequenas diferenças e persistindo na tonalidade principal, retornam agora as frases da primeira parte ${ }^{538}$ [cp. 207] e um Tutti tempestuoso [cp. 312] parece conduzir para o final. Após o acorde de dominante [cp. 317], porém, fagote, trompas, flautas, oboés e clarinetes executam sucessivamente o tema que havia sido apenas mencionado: ${ }^{539}$

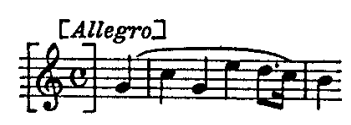

Segue-se novamente [cp. 334] uma frase cadencial [Schlußsatz]; novamente os instrumentos de cordas retomam aquela frase, e depois 0 flautim [cp. 337], oboés e trompas, e então, novamente, os violinos [ $c p$. 339]. Segue-se novamente para a cadência, mas com o acorde cadencial na tônica, os violinos retomam em Presto [cp. 362] (alguns compassos antes começou um Più stretto $)^{540}$ a frase tocada no compasso sessenta e sete do Allegro ${ }^{541}$; e a figura do baixo é a mesma que apareceu no compasso vinte e oito do primeiro Allegro ${ }^{542}$, e que, como já foi observado acima, recorda vivamente o mesmo, através de seu ritmo que é

\footnotetext{
${ }^{537}$ Cf. com o compasso 255 do terceiro movimento [N.T.]

${ }^{538}$ Isto é, tem início a reexposição [N.T.]

${ }^{539}$ Cf. compasso 35 [N.T]

${ }^{540} \mathrm{Na}$ verdade, Beethoven indica "sempre più Allegro" [N.T].

${ }^{541} 4^{\circ}$. Movimento [N.T.]

$5421^{\circ}$. Movimento [N.T.]
} 
intimamente aparentado com 0 tema principal. A orquestra inteira [cp. 390] (os baixos entram um compasso depois [cp. 391], imitando em cânone as vozes superiores), com o primeiro tema do último Allegro, conduz à conclusão, que acontece depois de quarenta e dois compassos que se detêm em diversas figuras pomposas e plenas de júbilo. Os acordes finais são colocados de maneira peculiar: a saber, depois do acorde que o ouvinte supõe ser o último [cp. 432], há um compasso de pausa [cp. 433], o mesmo acorde, um compasso de pausa, novamente 0 acorde, um compasso de pausa, e então durante três compassos [cp. 438], cada um deles contendo //50// uma vez aquele acorde em semínimas, um compasso de pausa [cp. 441], o acorde [cp. 442], um compasso de pausa [cp. 443], Dó unisono tocado pela orquestra inteira [cp. 444]. O apaziguamento completo do ânimo, proporcionado mediante diversas figuras conclusivas sucessivas, é neutralizado através desses acordes isolados com pausas (que lembram os golpes isolados do Allegro inicial da Sinfonia), e o ouvinte fica em novo estado de tensão através dos últimos acordes. Seu efeito é como o de um fogo que se acreditava apagado, e que volta a golpear as alturas com chamas claras e ardentes.

Beethoven manteve a ordem habitual dos movimentos na sinfonia; eles parecem se suceder uns aos outros de maneira fantástica, e o todo [Ganze] pareceria a muitos como uma genial rapsódia: mas a alma de todo ouvinte sensato [sinnig] certamente será tomada íntima e profundamente por um sentimento duradouro, que é justamente aquele anseio inefável e cheio de pressentimentos [unnennbare, ahnungsvolle Sehnsucht], e nele será mantida até o acorde final; e mesmo depois de alguns momentos após o fim da peça, o ouvinte não poderá sair desse maravilhoso reino dos espíritos [wundervolle Geisterreiche], onde o envolviam a dor e o prazer [Schmerz und Lust] configurados em sons. Além da disposição [Einrichtung] interna da instrumentação etc., é 
sobretudo o parentesco íntimo dos temas entre si, que engendra aquela unidade [Einheit] que mantém o ânimo [Gemüt] do ouvinte em um estado de espírito [Stimmung]. Essa unidade reina por toda parte na música de Haydn e de Mozart. Ela se torna mais clara para o músico quando ele descobre o baixo fundamental [Grundbaß] comum a duas frases distintas, ou quando a ligação [Verbindung] entre duas frases revela [essa unidade]: mas há um parentesco mais profundo [tiefere Verwandschaft] que não pode ser explicado desse modo, e que freqüentemente fala apenas de espírito para espírito [aus dem Geiste zum Geiste], e é esse parentesco que reina entre as frases dos dois allegros e do minueto, proclamando a genialidade refletida [besonnene Genialität] do Mestre. O Rec.[ensor] acredita poder resumir em poucas palavras seu julgamento sobre a esplêndida obra de arte do Mestre, dizendo: que ela foi inventada [erfunden] de maneira genial e executada [ausgeführt] com profunda reflexão [tiefer Besonnenheit], e que ela expressa num grau muito elevado o Romantismo da música [Romantik der Musik]. -

//51// Nenhum instrumento possui passagens difíceis de executar, mas somente uma orquestra extremamente certa de si e treinada, animada por um espírito único, pode se arriscar a tocar essa sinfonia, pois - menor erro cometido, em qualquer passagem, arruinaria irreparavelmente o conjunto. A alternância contínua, as entradas dos instrumentos de cordas e dos instrumentos de sopros, os acordes isolados a serem tocados após um silêncio, tudo isso exige a mais alta precisão; por isso, é aconselhável ao maestro que não se contente, como ocorre freqüentemente, em tocar a parte do primeiro violino mais forte do que o necessário. É melhor que ele conserve a orquestra permanentemente [sob o controle de] seu olho e de sua mão. Para este fim, ele será ajudado pela edição da parte do primeiro violino, que contém nela a entrada dos instrumentos obrigatórios [obligaten]. 
A gravura é correta e legível. O mesmo editor publicou uma redução dessa sinfonia para piano a quatro mãos, sob o título:

Cinquième Sinfonie de Louis van Beethoven, arrangée pour le Pianoforte à quatre mains. Chez Breitkopf et Härtel à Leipzic. (Pr. 2 Rthlr. $12 \mathrm{Gr}.)^{543}$

No mais, o Rec[ensor] não é especialmente favorável a esses arranjos: contudo, não se pode negar que o prazer de uma obra-prima que se ouviu com orquestra completa, [quando ouvida] num quarto solitário, freqüentemente excita a fantasia como antes, e coloca o ânimo no mesmo estado de espírito [Stimmung]. O pianoforte restitui a obra grandiosa, como faz um contorno [Umriß] com um grande quadro, que a fantasia vivifica com as cores do original. De resto, o arranjo da sinfonia foi feito com entendimento e discernimento; as necessidades do instrumento foram levadas em consideração como se deve, sem que fossem apagadas as particularidades do original.

${ }^{543}$ Em francês no original [N.T.] 


\section{REFERÊNCIAS BIBLIOGRÁFICAS}

ABRAMS, M. H. The mirror and the lamp: romantic theory and the critical tradition. N. York: Oxford Univ. Press, 1971.

ADDISON, J. The Spectator. Vol. II. London: J. \& R. Tonson, 1744.

ADORNO, T. W. "Zum Problem der musikalischen Analyse". In: Frankfurter Adorno Blätter Bd. 7. München: edition text+kritik, 2001, p. 73-89.

ALEWYN, R. Wackenroders Anteil. In: Germanic Review, N. 19/1, 1944, p. 48-58.

[Anônimo] Rezension. Beethoven: Trio op. 11. In: AmZ 1, Nr. 34 (22.05.1799), p. 541-42.

[Anônimo] Rezension. Beethoven: Sonaten op. 12. In: AmZ 1, Nr. 36 (05.06.1799), p. 570-71.

BACH, C. P. E. Versuch über die wahre Art, das Clavier zu spielen Bd. 1. Berlin: C. F. Henning, 1753.

BAEUMLER, A. Das Irrationalitätsproblem in der Ästhetik und Logik des 18. Jahrhunderts bis zur Kritik der Urteilskraft. Darmstadt: WBG, 1975.

BEHLER, E. "Wackenroder y la concepción musical del Primer Romanticismo". In: Anuário Filosófico N. 29, 1996, p.21-39.

BONDS, M. E. Wordless Rhetoric: musical form and the metaphor of the oration. Cambridge, MA: Harvard University Press, 1991.

BURKE, E. Uma investigação filosófica sobre a origem de nossas idéias do sublime e do belo. Trad. E. A. Dobránszky. Campinas: Papirus, 1993. 
CAESAR, K. A. (Hg). Geist der neuesten Philosophie des In- und Auslandes. Leipzig: Sommerschen Buchhandlung, 1801.

CARVALHO, M. V. Razão e sentimento na comunicação musical. Lisboa: Relógio d'Água, 1999.

CASSIRER, E. Die Philosophie der Aufklärung. Hamburg: Felix Meiner, 2007.

COLERIDGE, S. T. The literary remains. Vol. 2. Ed. H. N. Coleridge. London: William Pickering, 1836.

DAHLHAUS, C. Die Idee der absoluten Musik. Basel: Bärenreiter, 1994.

. Klassische und romantische Musikästhetik . Laaber: Laaber-Verl, 1988.

Musikästhetik. Köln: Hans Gerig, 1967. Trad. Port. Estética Musical. Trad. A. Morão. Lisboa: Ed. 70, 1991.

DIDEROT, D. Discurso sobre a poesia dramática. Trad. L. F. Franklin de Matos. São Paulo: Brasiliense, 1986

. Oeuvres Esthétiques. Ed. P. Vernière. Paris: Garnier, 1994.

EGGEBRECHT, H.H. "Das Ausdrucks-Prinzip im musikalischen Sturm und Drang". Deutsche Vierteljahrsschrift für Literaturwissenschaft und Geistesgeschichte. Vol. 29, 1955, p. 323-349.

ELIAS, N. Mozart: Zur Soziologie eines Genies. Frankfurt a.M.: Suhrkamp, 1993. Trad. Bras.: Mozart, a sociologia de um gênio. Trad. S. G. De Paula. Rio de Janeiro: Jorge Zahar, 1994.

FICHTE, J. G. "O Programa da Doutrina-da-Ciência (1800)". In: $A$ Doutrina-da-Ciência de 1794 e outros escritos. Trad. R. R. Torres Filho. São Paulo: Nova Cultural, 1988, p. 189-195.

FINK, G. W. "Antwort auf einige Punkte der Recension der Berliner allgemeine musikalische Zeitung, von $\mathrm{H}$. Dorn, im 31. Heft der Cäcilia”. In: AmZ30, Nr. 36 (03.09.1828).

FORCHERT, A. Studien zum Musikverständnis im frühen 19. Jahrhundert. Habilitationsschrift der Philosophischen Fakultät der Freien Universität Berlin, 1966. 
FORKEL, J. N. Allgemeine Geschichte der Musik I. Leipzig: Schwickert, 1788.

. Musikalisch-Kritische Bibliothek. Bd. 1 Hildesheim: G. Olms, 1964 (Reprographischer Nachdruck der Ausgabe Gotha, 1778).

FRANK, M. Einführung in die frühromantische Ästhetik. Frankfurt a.M.: Suhrkamp, 1989.

.; KURZ, G. (Hg). Materialien zu Schellings philosophischen Anfängen. Frankfurt a.M.: Suhrkamp, 1975.

GOETHE, J. W. Die Leiden des jungen Werther. München: DTV, 1978. Trad. Bras. Os sofrimentos do jovem Werther. Trad. L. C. Lack. São Paulo: Nova Alexandria, 1999.

Escritos sobre arte. Trad. M. A. Werle. São Paulo: Humanitas, 2005.

GRAPPIN, P. La théorie du génie dans le préclasscisme allemand. Paris: PUF, 1952.

GROVE, G. Beethoven and his nine symphonies. 3. ed. New York: Dover, 1962.

HANSLICK, E. Vom musikalisch-Schönen. Darmstadt: Wissenschaftliche Buchgesellschaft, 1973. Trad. Port. Do Belo Musical. Trad. A. Morão. Lisboa: Ed. 70, 1994

HARRIS, J. Three treatises: the first concerning art, the second conscerning music, painting and poetry, the third concerning happiness. 4th. Ed. London: C. Nourse, 1783.

HEGEL, G. W. F. Vorlesungen über die Ästhetik I. Frankfurt a.M.: Suhrkamp, 1986. Trad. Brasileira: Cursos de Estética I. Trad. M. A. Werle. São Paulo: Edusp, 2001.

HERDER, J.G. "Ob Malerei oder Tonkunst eine größere Wirkung gewähre? - Ein Göttergespräch". In: Sämtliche Werke Bd. 15. Hg. B. Suphan. Berlin: Weidmann, 1888, p. 222-240 (Abrev. SW).

. Schriften zu Literatur und Philosophie 1792-1800. Hg. H. D. Irmscher. Frankfurt/M: Dt. Klassiker Verlag, 1998. 
HERTRICH, E. Joseph Berglinger: eine Studie zu Wackenroders MusikerDichtung. Berlin: Walter de Gruyter, 1969.

HILLER, J. A. "Abhandlung von der Nachahmung der Natur in der Musik". In: Marpurg, F. W. Historisch-Kritische Beyträge zur Aufnahme der Musik. 1.Bd., 6. Stück. Berlin: Schützen, 1755, p. 515-543.

HOFFMANN, E.T.A. Briefe und Tagebücher I. Hg. W. Harich. Weimar: Erich Lichtenstein, 1924.

Die Serapions-Brüder. Darmstadt: Wissenschaftliche Buchgesellschaft, 1995. Trad. Port. "O poeta e o compositor". In: IRIARTE, R. Música e Literatura no Romantismo Alemão. Lisboa: Apaginastantas, 1987.

Schriften zur Musik. Darmstadt: Wissenschaftliche Buchgesellschaft, 1971.

HÖLDERLIN, F. Hipérion ou o eremita na Grécia. Trad. E. J. Paschoal. São Paulo: Nova Alexandria, 2003.

Sämtliche Werke Bd. 6 (Briefe). Hg. A. Beck. Stuttgart: W. Kohlhammer, 1965

HORN, F. "Musikalische Fragmente". In: AmZ 4, Nr. 25 (17.03.1802), p. 401-408; AmZ 4, Nr. 26 (24.03.1802), p. 417-426.

HORSTMANN, R.-P. "Kant hat die Resultate gegeben: Zur Aneignung der Kritik der Urteilskraft durch Fichte und Schelling". In: FULDA, H. F.; HORSTMANN, R.P. Hegel und die Kritik der Urteilskraft. Stuttgart: Klett-Cotta, 1990, pp. 45-65.

HUBERT, U. Karl Philipp Moritz und die Anfänge der Romantik. Frankfurt a.M.: Athenäum, 1971.

KANT, I. Anthropologie in pragmatischer Hinsicht. Hg. W. Weischedel. Frankfut a.M.: Suhrkamp, 2000. Trad. Bras.: Antropologia de um ponto de vista pragmático. Trad. C. A. Martins. São Paulo, lluminuras, 2006.

. Gesammelte Schriften Bd. XV/1 (Handschriftlicher Nachlaß). Berlin: Walter de Gruyter, 1923. 
Kritik der reinen Vernunft. Hamburg: Felix Meiner, 1998. Trad. Port.: Crítica da Razão Pura. Trad. M. Pinto dos Santos e A. F. Morujão. Lisboa: Calouste Gulbenkian, 2001. (Abrev. KrV)

. Kritik der Urteilskraft. Hamburg: Felix Meiner, 2001. Trad. Port.: Crítica da Faculdade do Juízo. Trad. A. Marques e V. Rohden. Lisboa: Imprensa Nacional, 1998 (Abrev. KdU).

Schriften zur Ästhetik und Naturphilosophie Bd. 3 (Kommentar). Hg. M. Frank; V. Zanetti. Frankfurt a.M.: Suhrkamp, 2001.

KEMPER, D. Sprache der Dichtung: Wackenroder im Kontext der Spätaufklärung. Stuttgart: Metzler, 1993.

KLOPSTOCK, F. G. "Von der heiligen Poesie“. In: Ausgewählte Werke. Hg. Von Karl August Schleiden. München: Carl Hanser, 1962.

KÖPKE, R. Ludwig Tieck: Erinnerungen aus dem Leben des Dichters. Bd. I. Leipzig: F. A. Brockhaus, 1855.

LAFITE, M. Musikästhetik im frühen 19. Jahrhundert. Dissertation zur Erlangung des Doktorgrades an der Universität Wien, 1974.

LONGINO, Do Sublime. Trad. F. Hirata. São Paulo: Martins Fontes, 1996.

MATOS, F. O filósofo e o comediante: ensaios sobre literatura e filosofia na llustração. B. Horizonte: Ed. UFMG, 2001.

MERLEAU-PONTY, M. "A linguagem indireta e as vozes do silêncio". In: Textos selecionados. Trad. P. Souza Moraes. S. Paulo: Abril Cultural, 1984, p. 141-175.

MICHAELIS, C. F. "Rückerinnerungen über Natur und Menschen". In: Monatsschrift für Deutsche III, 2 (1802, V. Heft, May).

. Ueber den Geist der Tonkunst und andere Schriften. Hg. L. Schmidt. Chemnitz : Schröder, 1997 (Abrev.: GT)

Über den Geist der Tonkunst mit Rücksicht auf Kants Kritik der ästhetischen Urteilskraft. Leipzig: Schäferischen Buchhandlung, 1795.

. "Ueber das Idealische der Tonkunst". In: Allgemeine Musikalische Zeitung, N. 29, p. 449-452 (13.04.1808). 
"Vermischte Bemerkungen über Musik", In: Berlinische musikalische Zeitung, 1. Jg., Nr. 4 (1805).

MORITZ, K.P. Andreas Hartknopf. Eine Allegorie. Berlin: Unger, 1786.

. Andreas Hartknopf Predigerjahre. Berlin: Unger, 1790.

. Beiträge zur Ästhetik. Mainz: DVB, 1989.

. Schriften zur Ästhetik und Poetik. (Kritische Ausgabe). Tübingen:

Max Niemayer, 1962

"Versuch einer Vereinigung aller schönen Künste und Wissenschaften unter dem Begriff des in sich selbst Vollendeten“. In: Berlinische Monatsschrift, 5. Bd., 3. Stück, 1785, p. 225-236.

NACHTSHEIM, S. Zu Immanuel Kants Musikästhetik. Chemnitz: Gudrun Schröder Verlag, 1997.

NEUBAUER, J. "Intellektuelle, intellektuale und ästhetische Anschauung". In: Deutsche Vierteljahrsschrift für Literaturwissenschaft und Geistesgeschichte. Vol. 46, 1972, p. 294-319.

PANOFSKY, E. Idea: a evolução do conceito de belo. Trad. P. Neves. S. Paulo: Martins Fontes, 2000.

PAUL, J. Vorschule der Ästhetik. Hamburg: Felix Meiner, 1990.

PIMENTA, P. P. Reflexão e moral em Kant. Rio de Janeiro: Azougue, 2004.

PRADO JR, B. "A força da voz e a violência das coisas". In: ROUSSEAU, J.J. Ensaio sobre a origem das línguas. Campinas: Ed. Unicamp, 2003, p. 7-96.

PRADO, R. Perversão da retórica, retórica da perversão. São Paulo: Ed. 34, 1997.

RAMEAU, J. P. Observations sur notre instinct pour la musique et sur son príncipe. Paris: Prault, 1754.

REICHARDT, J. F. Briefe, die Musik betreffend: Berichte, Rezensionen, Essays. Leipzig: Reclam, 1976. 
. Musikalisches Kunstmagazin Bd. 2 (7. Stück). Berlin: Im Verlage des Verfassers, 1791.

REIMANN, F. A. "Christian Friedrich Michaelis". In: Neue Nekrolog der Deutschen. 12. Jg., 1. Teil. Weimar: Voigt, 1836, p. 557-568.

REINHOLD, K. L. "Über das Fundament der Geschmackenlehre". In: Beiträge zur Berichtigung bisheriger Mißverständnisse der Philosophen“. Hamburg: Felix Meiner, 2004, p. 252-53.

[ROCHLITZ, F.] "Recension: Phantasien über die Kunst". In: AmZ 2, Nr. 23 (05.03.1800), p. 401-407.

ROSEN, C. A Geração Romântica. Trad. E. Seincman. S. Paulo: Edusp, 2000.

The Classical Style: Haydn, Mozart, Beethoven. London: Faber and Faber, 1976.

ROUSSEAU, J.J. Discurso sobre a origem e os fundamentos da desigualdade entre os homens. Trad. L. Santos Machado. In: "Os Pensadores". São Paulo: Abril, 1973, p. 221-326.

Ensaio sobre a origem das línguas. Trad. F. M. L. Moretto. Campinas: Ed. Unicamp, 2003.

. "Sonate" In: Encyclopédie ou dictionnaire raisonné des sciences, des arts et des métiers. Tome 15. Neufchastel: Samuel Faulche \& Co., 1765.

. "Sonate" In: Dictionnaire de Musique. Paris : Duchesne, 1768.

SCHELLING, F.W.J. Ausgewählte Schriften I. Frankfurt a.M.: Suhrkamp, 2003.

Obras escolhidas. Trad. R. R. Torres Filho. São Paulo: Abril Cultural, 1984.

SCHILLER, F. "Augustenburger Briefe". In: Über die ästhetische Erziehung des Menschen. Hg. K. Berghahn. Stuttgart: Reclam, 2000.

Fragmentos das preleções sobre estética do semestre de inverno de 1792-93. Trad. R. Barbosa. B. Horizonte: Ed. UFMG, 2004. 
Über naive und sentimentalische Dichtung. Stuttgart: Reclam, 2002. Trad. Bras. Poesia ingênua e sentimental. Trad. M. Suzuki. São Paulo: lluminuras, 1991.

. Werke (Nationalausgabe Bd 35). Weimar: Böhlau, 1964.

SCHLEGEL, A. W. Die Kunstlehre. Hg. E. Lohner. Stuttgart: W. Kohlhammer, 1963.

SCHLEGEL, F. Gespräch über die Poesie. Stuttgart: Metzler, 1968, p. 285. Trad. Bras. Conversa sobre a poesia e outros fragmentos. Trad. V.-P. Stirnimann. São Paulo: lluminuras, 1994.

. Kritische Ausgabe. Hg. E. Behler. Paderborn, Ferdinand Schöningh, 1958ss. (Abrev. KA).

. Literarische Notizen 1797-1801. Hg: Hans Eichner. Frankfurt/M: Ullstein, 1980.

SCHMIDT, J. Die Geschichte des Genie-Gedankens in der deutschen Literatur, Philosophie und Politik 1750-1945. 2 Bde. Darmstadt: Wissenschaftliche Buchgesellschaft, 1985.

SCHNAUS, P. E.T.A. Hoffmann als Beethoven-Rezensent der Allgemeinen Musikalischen Zeitung. München: Musikverlag Emil Katzbichler, 1977.

SCHOPENHAUER, A. Handschriftlicher Nachlaß Bd. IV (Neue Paralipomena). Hrsg. E. Grisebach. Leipzig: Reclam, 1931.

SCHRIMPF, H.-J. "W. H. Wackenroder und K. Ph. Moritz: Ein Beitrag zur frühromantischen Selbstkritik". In: Zeitschrift für deutsche Philologie. Bd. 84, 1964, p. 385-409.

SEIDEL, W. "Zählt die Musik zu den imitativen Künsten? Zur Revision der Nachahmungsästhetik durch Adam Smith“. In: FRICKE, J. P. Die Sprache der Musik. Festschrift K.W. Niemöller. Regensburg: Gustav Bosse, 1989.

SMITH, A. "Of the nature of that imitation which takes place in what are called the imitative arts". In: Essays on philosophical Subjects. Indianapolis: Liberty Fund, 1982.

SPOHR, L. Selbstbiographie. 1. Bd. Cassel und Göttingen: Georg H. Wigand, 1860. 
STRACK, F. "Die 'göttliche' Kunst und ihre Sprache. Zum Kunst- und Religionsbegriff bei Wackenroder, Tieck und Novalis". In: BRINKMANN, R. (Hg.). Romantik in Deutschland. Stuttgart: Metzler, 1978, p. 369-391.

SULZER, J. G. Allgemeine Theorie der schönen Künste, 1. Teil, Leipzig: Weidmann, 1771.

Allgemeine Theorie der schönen Künste, 2. Teil, Leipzig: Weidmann, 1774.

SUZUKI, M. O gênio romântico: crítica e história da filosofia em $F$. Schlegel. São Paulo: lluminuras, 1998.

TADDAY, U. Die Anfänge des Musikfeuilletons: der kommunikative Gebrauchswert musikalischer Bildung in Deutschland um 1800. Stuttgart: Metzler, 1993.

. "Und ziehe mich still in das Land der Musik, als in das Land des Glaubens, zurück: Zu den pietistischen Grundlagen der Musikanschauung W. H. Wackenroders". In: Archiv für Musikwissenschaft 56, Heft 2 (1999).

TIECK, L. Phantasus: eine Sammlung von Märchen, Erzählungen und Schauspielen. 2. Bd. Berlin: G. Reimer, 1845.

TILLIETTE, X. L'Absolu et la philosophie: essais sur Schelling. Paris: PUF, 1987.

Recherches sur l'intuition intellectuelle de Kant à Hegel. Paris: Vrin, 1995.

TORRES FILHO, R. R. Ensaios de filosofia ilustrada. São Paulo: lluminuras, 2004.

TRIEST, J. "Bemerkungen über die Ausbildung der Tonkunst in Deutschland im 18. Jh". In: Allgemeine Musikalische Zeitung 3, No. 14, (01.01. 1801).

. (Continuação) "Bemerkungen über die Ausbildung der Tonkunst in Deutschland im 18. Jh". In: Allgemeine Musikalische Zeitung 3, No. 18, (28.01. 1801).

TRINGALI, D. A Arte Poética de Horácio. São Paulo: Musa, 1993. 
VIËTOR, K. "Die Idee des Erhabenen in der deutschen Literatur". In: Geist und Form: Aufsätze zur deutschen Literaturgeschichte. Bern: A. Francke Verlag, 1952, p. 234-266.

VIETTA, S.; KEMPER, D. Wilhelm Heinrich Wackenroder im Spiegel der Quellenforschung und Editionsgeschichte: Katalog zur Ausstellung der Universitätsbibliothek Hildesheim vom 28. April bis 28. Mai 1993. Lamspringe: Quensen, 1993.

WACKENRODER, W. H. Sämtliche Werke und Briefe. Historisch-kritische Ausgabe in 2 Bde. Hg. S. Vietta, R. Littlejohns. Heidelberg: Carl Winter, 1991 (Abrev. HKA). Tradução parcial portuguesa: IRIARTE, R. (Org). Música e Literatura no Romantismo Alemão. Lisboa: Apaginastantas, 1987.

WAIZBORT, L. "Chaves para ouvir Schumann (paralipomena à Kreisleriana - I)". In: Novos Estudos Cebrap. Nr. 75 (julho de 2008), p. $185-210$.

WALLACE, R. Beethoven's Critics. Cambridge: Cambridge University Press, 1989.

YOUNG, E. Conjectures on original composition. London: A. Millar, 1759. 